\title{
NORTHWEST AFRICA 8694, A FERROAN CHASSIGNITE: BRIDGING THE GAP BETWEEN NAKHLITES AND CHASSIGNITES
}

\author{
R.H. Hewins ${ }^{1,2}$, M. Humayun ${ }^{3}$, J.-A. Barrat ${ }^{4}$, B. Zanda ${ }^{1,5}$, J.-P. Lorand ${ }^{6}$, S. Pont ${ }^{1}$, N. Assayag ${ }^{7}$, P. \\ Cartigny $^{7}$, S. Yang ${ }^{3}$ and V. Sautter ${ }^{1}$. \\ Corresponding author: Roger Hewins, Muséum national d'Histoire naturelle, \\ Hewins@scarletmail.rutgers.edu, $+33616212991 \&+33147093769$ \\ ${ }^{1}$ IMPMC, MNHN, Sorbonne Universités, 75005 Paris, France. \\ ${ }^{2}$ EPS, Rutgers University, Piscataway, NJ 08854, USA. \\ ${ }^{3}$ DEOAS \& NHMFL, Florida State University, Tallahassee, FL 32310, USA. \\ ${ }^{4}$ UBO-IUEM and CNRS UMR 6538, 29280 Plouzané, France. \\ ${ }^{5}$ IMCCE, Observatoire de Paris, CNRS UMR 8028, 75014 Paris, France. \\ ${ }^{6}$ LPGN, CNRS UMR 6112, Université de Nantes, BP 92208, 44322 Nantes, France. \\ ${ }^{7}$ IPGP UMR 7154, Université Denis Diderot (Paris 7) \& PRES Sorbonne Paris Cité, Paris 75005, France. \\ (hewins@ rci.rutgers.edu)
}

Resubmitted to Geochimica et Cosmochimica Acta, 12 March, 2020 
Abstract-The origin(s) of the chassignites and nakhlites, closely related martian olivine and augite cumulates, respectively, are much debated. Northwest Africa (NWA) 8694 is the third chassignite to be discovered and the most ferroan, containing $85 \%$ olivine $\left(\mathrm{Fo}_{54}\right)$. Its $\mathrm{O}$-isotope compositions $\left(\delta^{18} \mathrm{O} \sim 4.4 \%\right.$, $\Delta^{17} \mathrm{O} \sim 0.30 \%$ ) are typical of other martian meteorites. It has adcumulate texture and contains cumulus chromite, poikilitic pigeonite $\left(\mathrm{En}_{56} \mathrm{Fs}_{37} \mathrm{Wo}_{7}\right)$ and mesostasis (trapped interstitial liquid). The latter contains pyroxene and plagioclase $\left(\mathrm{An}_{23} \mathrm{Ab}_{70} \mathrm{Or}_{8}\right)$ plus rare $\mathrm{K}$ feldspar $\left(\mathrm{Or}_{74}\right)$, and has a trachyandesitic to trachytic bulk composition. Melt inclusions in olivine contain a variety of phases including biotite and rare amphibole. Olivine, chromite, and pigeonite compositions are intermediate between those of the other chassignites and those of the nakhlites. Augite, which appears to mantle pigeonite, has a composition overlapping that in nakhlite NWA 998 and some other nakhlites at $\left(\operatorname{En}_{41-40} \mathrm{Wo}_{38-39}\right)$. The augite lamellae in pigeonite 1-2 $\mu \mathrm{m}$ in apparent width, and the survival of $\mathrm{Ca}$ zoning in olivine, suggest a near-surface cooling environment. The bulk-rock REE concentrations in the three chassignites do not correlate with Mg\# but depend on the abundance of trapped liquid. The form of REE patterns calculated for olivine subtraction is very like those of nakhlite mesostases, but the observed concentrations of LREE in NWA 8694 trapped liquid have a very steep slope. This is explained by undersampling of baddeleyite and zirconolite that occur near olivine contacts with mesostasis. Though pyroxene is unzoned, its trace element variations indicate fractional crystallization. The range of olivine compositions in the three chassignites $\left(\mathrm{Fo}_{79-54}\right)$ is too large to result from the crystallization sequential growth of olivine from a single magma undergoing fractional crystallization. The Ge/Si ratios show degassing of NWA 8694 which sets this chassignite apart from other chassignites and nakhlites, implying a unique batch of magma for its genesis. Many potential parent liquids are capable of generating the NWA 8694 olivine composition, though not its alkaline mesostasis. We calculated that Nakhla parent liquid NA01a (Stockstill et al., 2005) with 10\% Nakhla core olivine added would produce both olivine crystals and alkaline daughter liquids with compositions matching those of NWA 8694. This meteorite is a chassignite cumulate containing nakhlitic mesostasis, a direct link between the chassignites and the nakhlites and the association of dunitic to trachytic compositions is reminiscent of terrestrial shield volcanoes. Chassignites and nakhlites were possibly formed when solidification fronts on chamber walls were disrupted, mainly as side eruptions of olivine-charged magmas from the deeper zones, and augite-charged fractionated magmas from nearer the summit of a volcano resembling Piton de la Fournaise on Earth.

\section{INTRODUCTION}

Martian meteorites have been a major source of information on Mars since Nakhla was first recognized as having the mineral assemblage of a planetary igneous rock (Reid and Bunch, 1975) with a young crystallization age (Gale et al., 1975). That same year Mason et al. (1975) suggested that Chassigny was a cumulate from the nakhlite parent liquid. The chassignites are the least well known of the SNC meteorites (shergottites; nakhlites and chassignites), consisting until now of only two meteorites, Chassigny (Floran et al., 1978; Johnson et al., 1991) and North West Africa (NWA) 2737 (Beck et al., 2006; Treiman et al., 2007; He et al., 2013). Chassignites share many characteristics with nakhlites, including crystallization and ejection ages (Nyquist et al., 2001), trace element abundance patterns (Mason et al., 1975; Wadhwa and Crozaz, 1995; Beck et al., 2006; Udry and Day, 2018), and volatile element abundances (McCubbin et al., 2013). Chassignites are adcumulate dunites with cumulus olivine and chromite, while nakhlites are augite cumulates. Chassignite and nakhlite textures resemble those of cumulates in Archean rocks - dunite in komatiite flows and pyroxenite in the lower parts of associated thick differentiated tholeiitic flows (Arndt et al., 1977; Friedman-Lentz et al., 1999; Treiman, 2005; Day et al., 2006). Dunites simi ar o chassignites have also been observed in association with shield volcanoes, as xenoliths and as cumulates beneath the basaltic lavas (Barrat and Bachèlery, 2019; Babkine et al., 1966).

A genetic relationship between chassignites and nakhlites has long been considered (Mason et al., 1975; Stolper et al., 1979; McCubbin et al., 2013). There is a sequence of textures and compositions in nakhlites reflecting cooling history that allowed them to be ordered as in a single igneous body (Mikouchi et al., 2003; Day et al., 2006), with chassignites added to the base of this sequence (e.g. McCubbin et al., 2013). However, considering subtle 
differences in otherwise similar nakhlites and in chassignites, such as their Ar-Ar ages and augite incompatible element fractionation trends, these rocks may represent several closely related flows or shallow intrusions, possibly with different parent magmas derived from a common mantle source (Wadhwa and Crozaz, 1995; Jambon et al., 2016; Balta et al., 2017; Mikouchi et al., 2017, Cohen et al. 2017; Udry and Day, 2018). Nevertheless, the similarities of nakhlites and chassignites suggest that the most magnesian nakhlites, like NWA 998 (Treiman and Irving, 2008), could have a close physical or genetic relationship to the most evolved chassignites.

Northwest Africa 8694 is a $55 \mathrm{~g}$ stone obtained in Agadir in July, 2014. It has a texture and modal composition like those of the other chassignites, but is highly ferroan (Hewins et al., 2015, 2017). The olivine composition of NWA 8694 expands the known range of $\mathrm{Mg} \#(100 \mathrm{x}$ atomic $\mathrm{Mg} /(\mathrm{Fe}+\mathrm{Mg})$ ratio $)$ in the chassignites from 77 in NWA 2737 to 54 in NWA 8694, and is intermediate between those of Chassigny and nakhlites. We have therefore undertaken a petrologic and geochemical study of this key meteorite, and compare it to the most magnesian, least fractionated, most mesostasis-poor nakhlites like NWA 998 (Mikouchi et al., 2006: Treiman and Irving, 2008). Cosmic-ray exposure (CRE) ages and noble gas compositions observed for NWA 8694 chassignite-suggest it is launch-paired with Miller Range (MIL) nakhlites (Nagao et al., 2019). Our study sheds light on the origin and evolution of chassignite parent magmas, and confirms the close relationships between chassignites and nakhlites.

\section{SAMPLES AND METHODS}

\subsection{Oxygen Isotopes}

Triplicate oxygen isotope analyses were performed at the Institut de Physique du Globe de Paris, over three distinct sessions. Analytical methods are similar to those documented in Rumble et al. (1997). Briefly, prior to analysis, samples were pre-fluorinated overnight using $\mathrm{BrF}_{5}$. Both samples and garnet standard UWG-2 (Gore Mountain mine, Adirondack Mountains, New York, see Valley et al. 1995) were then analysed using laser fluorination. Oxygen isotopic ratios $\left({ }^{18} \mathrm{O} /{ }^{16} \mathrm{O}\right)$ were normalized to UWG-2 garnet with $\delta^{18} \mathrm{O}=5.75 \%$ o (Valley et al. 1995) and reported versus the international standard, V-SMOW (standard mean ocean water) using the conventional delta-notation, where

$$
\delta^{1 \mathrm{X}} \mathrm{O}=\left({ }^{1 \mathrm{X}} \mathrm{O} /{ }^{16} \mathrm{O}_{\text {sample }} /{ }^{1 \mathrm{X}} \mathrm{O} /{ }^{16} \mathrm{O}_{\text {standard }}-1\right) \times 1000 \text {, with } \delta^{1 \mathrm{X}} \mathrm{O} \text { denoting either }{ }^{17} \mathrm{O} \text { or }{ }^{18} \mathrm{O} \text {. }
$$

\subsection{Mineralogy-petrology}

Three parallel polished sections of NWA 8694 exposing a total area of $\sim 3 \mathrm{~cm}^{2}$ wer $\overline{=}$ died using optical microscopy, scanning electron microscopy (SEM), and electron probe microanalysis (EPMA). Two sections were subsequently split horizontally to make doubly polished, double-sided epoxy mounts. Similar analyses were made on Chassigny and NWA 2737 for comparison. Backscattered electron (BSE) maps, X-ray maps, and images of selected regions were made at MNHN using a Tescan VEGA II LSU SEM in conventional mode (mainly $15 \mathrm{keV}$ and $<20 \mathrm{nA}$ ), and minerals were characterized with an SD3 (Bruker) Energy Dispersive Spectrometer (EDS). We used a scan speed of $64 \mu \mathrm{s} / \mathrm{pxl}$ and a pixel size of $884 \mathrm{~nm}$ for cartography. Phases were identified from BSE intensity and modal abundances were calculated after scanning $200,000,000 \mathrm{px}^{2}$ per section. Sulfide microphases were located by manual scans in the BSE mode on sections 2 and 3, and were identified with EDS. Their compositions were analyzed at $15 \mathrm{kV}$ accelerating voltage by a PhiRhoZ EDS standardless procedure after careful imaging of each grain in the BSE mode at high magnification (x 2,000-x 10,000); information on the accuracy of this technique are given in Gattacceca et al. (2013). Minor-element X-ray maps of olivine crystals were also made using a Cameca SX100 electron microprobe at the Université Paris VI with a 500 nA current, after quantitative analyses because of the risk of beam damage (Goodrich et al., 2013). Quantitative analyses of all minerals except for sulfides were made by wavelength-dispersive spectrometry on the Cameca SXFive electron microprobe at the Université Paris VI, using an $\mathrm{LaB}_{6}$ source, at $15 \mathrm{keV}$. The current was generally $10 \mathrm{nA}$ with a focused beam but 4 $\mathrm{nA}$, with $6 \times 8 \mu \mathrm{m}$ and up to $12 \times 15$ rasters, was used for feldspathic and glassy material. The quality of the analyses was checked using San Carlos and Eagle Station olivine, and Astimex MINM25-53 albite, orthoclase, quartz, kaersutite, and biotite, as internal standards.

\subsection{LA-ICP-MS}


Laser ablation inductively coupled plasma mass spectrometry (LA-ICP-MS) analyses with an Electro Scientific Instruments New Wave ${ }^{\text {TM }}$ UP193FX excimer (ArF) laser coupled to a Thermo Element XR ${ }^{\mathrm{TM}}$ sector field ICP-MS were performed at the Plasma Analytical Facility, at the NHMFL, Florida, using methods described elsewhere (Humayun et al., 2010; Yang et al., 2015; Oulton et al., 2016). A total of 78 peaks of 72 elements were monitored in low mass resolving power to correct for isobaric interferences, including from doubly charged ions (Yang et al., 2015). The ICP-MS was tuned to yield ${ }^{238} \mathrm{UO}^{+} / 238 \mathrm{U}^{+} \sim 0.3 \%$. Individual mineral grains were analysed with 25 or $50 \mu \mathrm{m}$ spots and 5-second laser dwell time per spot, or with $100 \mu \mathrm{m}$ spots and 20-second laser dwell time per spot, at $50 \mathrm{~Hz}$ laser repetition rate. Abundances of major elements and most lithophile elements were calibrated using the USGS glass standards BCR-2g, BHVO-2g and BIR-1g (Humayun et al., 2010; Jochum et al., 2011), with the remaining elements calibrated against NIST SRM 610, NIST SRM 1263a, and the iron meteorites Hoba and North Chile (Humayun et al., 2007; Yang et al., 2015; Oulton et al., 2016). Individual spot analyses were taken on two sections of MNHN Chassigny 2525 (Sp1 and Sp2) and on a doubly polished epoxy mount of NWA 8694. A bulk analysis of NWA 8694 was performed on the reverse side of the NWA 8694 mount with a $100 \mu \mathrm{m}$ spot size, rastered at $10 \mu \mathrm{m} / \mathrm{s}$ with $50 \mathrm{~Hz}$ laser repetition rate, covering an area of $2 \times 3 \mathrm{~mm}$.

\subsection{ICP-AES and ICP-SFMS}

A $0.136 \mathrm{~g}$ sample of NWA 8694 was crushed using a boron carbide mortar and pestle into a homogenous fine-grained powder in clean room conditions at the Institut Universitaire Européen de la Mer (IUEM), Plouzané, at the same time as a $0.115 \mathrm{~g}$ sample of Chassigny. The powder was dissolved and analyzed for major and trace element concentrations by ICP-AES (inductively coupled plasma - absorption emission spectrometry), and by ICPSFMS (inductively coupled plasma - sector field mass spectrometry) following the procedures described by Barrat et al. (2012). Based on replicate standards and samples (Barrat et al., 2012, 2014, 2016), the precision for abundances is much better than $5 \%$. The precision for trace element ratios (e.g., Eu/Eu*, where Eu* is the interpolated Eu for a smooth CI-normalized rare earth element $(\mathrm{REE})$ pattern, such that $\left.\operatorname{Eu}_{\mathrm{n}} *=\left(\operatorname{Sm}_{\mathrm{n}} \times \mathrm{Gd}_{\mathrm{n}}\right)^{1 / 2}\right)$ is better than $2.5 \%$ ( $2 \times$ relative standard deviation).

\section{RESULTS}

\subsection{Oxygen isotopes}

The measured $\delta^{18} \mathrm{O}$-values ranged from 4.53 to $4.17 \%$ with an average value of $4.39 \pm 0.19 \%$ ( $1 \mathrm{~s}$ ) within the range of previous measurements (e.g. Franchi et al., 1999). $\Delta^{17} \mathrm{O}$-values [where $\Delta^{17} \mathrm{O}=\delta^{17} \mathrm{O}\left(\left(\delta^{18} \mathrm{O} / 1000+1\right)^{0.5305}-1\right) \mathrm{x}$ 1000 ] varied between 0.274 and $0.358 \%$, averaging $0.303 \pm 0.048 \%$ o $(1 \sigma, \mathrm{n}=3$, from 1 sample) values within the range of other studies (e.g. $0.275 \pm 0.013$ using the data of Franchi et al. (1999) recalculated using the 0.5305 massexponent, $\mathrm{n}=34$ from 11 samples). Our measurements are shown in Fig. S1 along with the Mars Fractionation Line calculated by regression of analyses tabulated by Ali et al. (2016). Our values are typical of other martian meteorites and provide an independent validation that NWA 8694 originates from the parent body of other nakhlites and chassignites.

\subsection{Petrography}

The textures of the three chassignites are compared in Fig. 1. NWA 8694 is a cumulate dunite with $85 \%$ olivine grains up to $1 \mathrm{~mm}$ in size, with similar mineral proportions and textures to the two other chassignites now known, though clearly Chassigny has the most olivine and the least intercumulus material (Fig. 1). Full resolution BSE images are given in Fig. S2. Olivine displays irregular and planar fractures in NWA 8694, indicating shock as in Chassigny (Langenhorst and Greshake, 1999). Chromite is highly fractured; it is enclosed by and molded round olivine, and is euhedral where enclosed by pyroxene. The main interstitial (intercumulus or adcumulus) phases in NWA 8694 are poikilitic pigeonite and augite, both with very fine $(\sim 1-2 \mu \mathrm{m})$ exsolution lamellae. The augite occurs between olivine and pigeonite in many cases, swathing the olivine, and also in mesostasis patches and melt 
inclusions. The pigeonite in some mesostasis patches encloses feldspar or maskelynite laths. Minor phases include apatite, and ilmenite and accessory phases are $\mathrm{Fe}-\mathrm{Ni}(\mathrm{Cu})$ sulfides and $\mathrm{Zr}$-rich oxides (baddeleyite and zirconolite).

The abundances of constituent phases identified by BSE intensity were determined by counting $~ 250,000,000$ $\mathrm{px}^{2}$ each for three sections, and are shown in Table 1, along with those of the other two chassignites (Floran et al., 1978; Udry and Day, 2018; Mikouchi et al., 2005; Beck et al., 2006; Trieman et al., 2007). NWA 8694 has significantly less olivine, $84.9 \pm 1.3 \%$, than Chassigny and NWA 2737 with $90.5 \pm 1.3$ and $90.7 \pm 2.4 \%$ respectively; and less chromite, $0.8 \pm 0.1$ vs. $1.4 \pm 0.3$ and $3.3 \pm 0.9 \%$; but significantly more pyroxene, $10.6 \pm 1.9$ vs. $3.2 \pm 2.1$ and $5.3 \pm 3.0$, respectively. Abundances of feldspar/glass are not significantly different. Thus NWA 8694 contains more intercumulus material than the other chassignites, though these phases are heterogeneously distributed, as reflected in the different abundances in different sections of the same meteorite. The meteorite has an adcumulate texture except in small patches where abundant interstitial material gives an orthocumulate texture (Fig. 1).

Interstices between olivine grains are largely filled by pigeonite and augite. The continuity of augite lamellae across different interstitial pigeonite areas (Fig. S3) indicates that the pigeonite is poikilitic to olivine and suggests that it is an adcumulus phase, as in Fig. 2 of Wager et al. (1960). The olivine contains partly crystalline melt inclusions, surrounded by radial fractures (Fig. 2a).

The main phases in melt inclusions are orthopyroxene and K- or Na-bearing glasses; minor phases include apatite (identified in half of the 25 inclusions studied for sulfides), pyrrhotite, amphibole and biotite, which are significantly less abundant. The melt inclusions may be dominated by one phase (chromite, pyroxene or Al-rich glass) but many are polymineralic.

Mesostasis occurs instead of pyroxene between some olivine grains (Fig. 2b). The pyroxene of this mesostasis (orthopyroxene, pigeonite, and augite) is partly attached to olivine walls and is partly subophitic to plagioclase laths. Feldspar is dominant in some interstitial patches, in which plagioclase is accompanied by minor K-feldspar. Other phases include apatite needles, biotite, pyrrhotite, pyrite, and ilmenite. Zirconolite and baddeleyite were identified by EDS as micron scale grains, occurring near olivine rims. They are partly enclosed inside ilmenite, or plagioclase, or associated with other interstitial minerals.

Like the other two chassignites, NWA 8694 contains trace amounts of $\mathrm{Fe}-\mathrm{Ni}(\mathrm{Cu})$ sulfides. Euhedral (prismatic) to spherical Ni-bearing pyrrhotite crystals (1 to $10 \mu \mathrm{m}$ in maximum dimension) occur in most melt inclusions in olivine (Fig. 3a,b). Enclosed pyrrhotite often coexists with apatite, and less frequently with chromite, pyroxene and/or amphibole. Such inclusions were occasionally preserved in interstitial trapped melt. Sulfide in intercumulus spaces are either Ni-pyrrhotite (Po) enclosing occasional pentlandite blebs (Pn) or discrete pyrite (Py) which was also identified in 3 fractured melt inclusions (over the 25 studied). Both Fe sulfides occur as polyhedral blebs evenly distributed throughout the two polished thin sections investigated here. Intercumulus sulfides can occur side by side with olivine, pyroxenes, chromite and interstitial feldspathic glass (Fig. 3c,d). Pyrrhotite and pyrite have not been observed to coexist within a single sulfide bleb. Pyrite shows fracture networks filled with Fe oxyhydroxides (Fig. 3d), a well-known alteration product of Fe sulfides from hot desert meteorite finds (Lorand et al., 2015). Interstitial pyrrhotite was also locally altered. Other accessory phases include baddeleyite and zirconolite (Fig. 3e,f) both occurring close to olivine-mesostasis contacts.

\subsection{Mineral compositions}

\subsubsection{Olivine}

The olivine composition by EMP is $\mathrm{Fo}_{53.5 \pm 0.4} \mathrm{Fa}_{46.5 \pm 0.4}$ (Table 2a, S1), with no Fe-Mg zoning and a typical martian $\mathrm{FeO} / \mathrm{MnO}$ ratio of $48.3 \pm 1.6$ (uncertainty is standard deviation and $\mathrm{n}=227$ ). Analysis of olivine (cores only) by LA-ICP-MS gives $\mathrm{Fo}_{54.1 \pm 0.1}$. Fig. 4 shows that NWA 8694 is intermediate in $\mathrm{FeO}$ content between olivine of the other chassignites (NWA 2737 and Chassigny), and the less equilibrated nakhlites such as NWA817 where olivine cores still preserve primary compositions (Sautter et al., 2002; Ir iman et al., 2005; Udry et al., 2012; Udry and Day, 2018). Both EMP and LA-ICP-MS data are plotted for Curassigny. The olivine contains 346 ppm Ni (s.d. 5) compared to 419 ppm (Udry and Day, 2018) or 500 ppm (this work) for Chassigny, and 642 ppm for NWA 2737 
(Udry and Day, 2018). Though the crystals are equilibrated in Fe-Mg, there is a large range of $\mathrm{CaO}$ concentrations in NWA 8694 olivine, $0.29-0.04$ wt. \% (Fig. 4b) in part due to the incompatible nature of $\mathrm{Ca}$, but there is a weak depletion of $\mathrm{Ca}$ in crystal rims close to interstitial material $(0.18 \pm 0.02$ to $0.10 \pm 0.02 \mathrm{wt} \% \mathrm{CaO})$. However we did not detect zoning in X-ray maps of selected olivine grains, including for slow-diffusing elements like P.

\subsubsection{Pyroxenes}

Chassignite pyroxene and olivine assemblages are shown in Fig. 5, with compositions given in Table $2 \mathrm{~b}$ and S1. The dominant pyroxene in NWA 8694 is pigeonite with composition $\mathrm{En}_{55.8 \pm 0.9} \mathrm{Fs}_{37.5 \pm 1.0} \mathrm{Wo}_{6.7 \pm 1.3}$, and $\mathrm{FeO} / \mathrm{MnO}$ of $28.7_{ \pm}$1.9. The augite is $\mathrm{En}_{40.6 \pm 0.2} \mathrm{Fs}_{16.1 \pm 0.6} \mathrm{Wo}_{43.9 \pm 0.5}$, s.d.0.2, 0.6, 0.5, with an FeO/MnO ratio of 27.4, s.d. 3.2, (neglecting strong overlap compositions). The minor orthopyroxene, particularly in melt inclusions in olivine, is $\mathrm{En}_{59.9 \pm 0.4} \mathrm{Fs}_{37.7 \pm 0.9} \mathrm{Wo}_{2.4 \pm 0.8}$, with $\mathrm{FeO} / \mathrm{MnO}$ ratio of $30.2 \pm 3.0$, and $\mathrm{Al}_{2} \mathrm{O}_{3}$ up to 4 wt. \%. Though all NWA 8694 pyroxenes cluster in Fig. 5, we distinguish poikilitic, mesostasis and inclusion pyroxene in Fig. S4, which shows that they differ mainly in orthopyroxene abundance. Calcium variation is partly due to overlap on host and exsolution lamellae.

Although all chassignite parameters to date are more magnesian than those of nakhlites, Fig. 5 shows that the compositions of augite in NWA 8694 and in nakhlites overlap. The minor elements in augite as a function of Ca also show a partial overlap between chassignites and NWA 998, and cores in some other nakhlites (Udry and Day, 2018), as shown in Fig. 6. Other more fractionated nakhlites show a much wider range of minor element concentrations, off the scale of this figure for $\mathrm{Al}$ and $\mathrm{Ti}$, and reaching much lower $\mathrm{Cr}$ values.

\subsubsection{Chromite}

The range of chromite compositions (Table $2 \mathrm{a}$ and $\mathrm{S} 1$ ) is $\mathrm{Spl}_{11-21} \mathrm{Chr}_{57-76} \mathrm{Usp}_{5-20} \mathrm{Mag}_{7-12}$. This range overlaps the compositions of chromite in the other chassignites, but it lacks the most $\mathrm{Cr}$-rich compositions and is on average richer in $\mathrm{Ti}$ and $\mathrm{Fe}^{3+}$ (Fig. 7). Accessory ilmenite, $\mathrm{Ilm}_{96} \mathrm{Hem}_{04}$, present in the interstitial material is very similar in composition to ilmenite in Chassigny, except that the latter is more magnesian (Floran et al., 1978). Chromite is absent in nakhlites while ilmenite occurs primarily as lamellae in Ti-magnetite as a result of oxy-exsolution.

\subsubsection{Feldspars}

Feldspathic material occurs in the interstitial trapped material and, though featureless in BSE, it appears to be feldspar laths embraced in part by sub-ophitic pyroxene. EPM data for this (Table 3, S1) are plotted in Fig. 8 Feldspar is mainly Na-rich with oligoclase composition $\left(\mathrm{An}_{22.5 \pm 5.1} \mathrm{Ab}_{70.0 \pm 5.8} \mathrm{Or}_{7.5 \pm 2.3}\right)$ but has a range of $\mathrm{An}_{27}-\mathrm{Or}_{7 y}$ through intermediate alkali feldspar to K-rich feldspar $\mathrm{An}_{1.9 \pm 1.0} \mathrm{Ab}_{24.2 \pm 4.9} \mathrm{Or}_{73.9 \pm 5.5}$.

The interstitial feldspar composition in Chassigny (this work, Floran et al., 1978) has a similar range to NWA 8694 from plagioclase to alkali feldspar as shown in Fig. 8a, but is more calcic and less potassic. These two chassignites have similar feldspar compositions to those of the-Lafayette, Nakhla and NWA 5790. Interstitial feldspar analyses for NWA 2737 shown in Fig.8a are analbite, confirming work by Beck et al. (2006) and Treiman et al. (2007), and in Fig. 8b plot in the field of alkali glasses in melt inclusions (see below).

Because of questions of $\mathrm{Na}$ loss, admittedly not usual in maskelynite but possible under the electron beam, we examine the stoichiometry of our analyses. Both Fig. 9a and 9b show half the join $\mathrm{NaAlSi}_{3} \mathrm{O}_{8}-\mathrm{CaAl}_{2} \mathrm{SiO}_{8}$ and their proximity to the line shows that NWA 8694 feldspar analyses are stoichiometric. Bulk analyses of interstitial trapped melt analyzed by LA-ICP-MS are also shown in Fig. 9, excluding analyses with major overlaps on olivine, pyroxene or apatite. Theyproject fairly close to feldspar compositions, consistent with the high feldspar contents of the regions analyzed.

\subsubsection{Melt Inclusion Glass}

Two discrete $\mathrm{Si}$ - and Al-bearing glass phases may be observed as anhedral patches in the melt inclusions in olivine (Fig. 2c), the higher $\mathrm{Z}$ phase being richer in $\mathrm{K}$ (up to $5 \mathrm{wt} \% \mathrm{~K}_{2} \mathrm{O}$ ) and also Ca (Table 4). Most of the Si-Alrich glasses shown in Fig. $8 \mathrm{~b}$ and 9 are far from feldspar composition. The low-Z glass is very varied in composition, and we separate it into several somewhat arbitrary composition groups. These are Al- (and Na-) rich, Al-poor (though K-rich glass is also Al-poor), and cation-poor, and are distinguished in Fig. 9 and 10. They are all very $\mathrm{Si}$-rich (70-79 wt\% $\mathrm{SiO}_{2}$ ) except for the Al-rich group some of which are close to albite in composition. 
We also plotted melt inclusion glasses in the two other chassignites in Fig. 8b. For Chassigny both Floran et al. (1978) and Johnson et al. (1991) reported K- and Na-bearing glasses, similar to the "K-rich" glass of NWA 8694, and Johnson et al. (1991) also reported albitic glass similar to the "Al-rich" glass in NWA 8694. He et al. (2013) and Beck et al. (2006) reported Si-Al-rich alkali glass in inclusions in NWA 2737 with a wide range of Na/K ratios and low $\mathrm{Ca}$.

\subsubsection{Sulfides}

Sulfide compositions are shown in Table 5. MI-enclosed pyrrhotite is ( $\mathrm{Fe}, \mathrm{Ni})_{0.87} \mathrm{~S}$ (monoclinic pyrrhotite). Interstitial grains show a larger compositional range from $(\mathrm{Fe}, \mathrm{Ni}) \mathrm{S}$ (troilite) to $(\mathrm{Fe}, \mathrm{Ni})_{0.82} \mathrm{~S}$ (smythite): their mean metal-to-sulfur ratio is centered on $\mathrm{Fe}_{0.9} \mathrm{~S}$ (hexagonal pyrrhotite) in both NWA 8694 and Chassigny (Floran et al., 1978; Lorand et al., 2018). (NWA 2737 contains troilite rather than pyrrhotite). Whether enclosed in olivine-hosted melt inclusions or occurring as interstitial grains, the NWA 8694 pyrrhotite compositions have the same Ni contents ( $1.2 \pm 0.5$ vs. $1.1 \pm 0.5$ wt. $\% ; n=16$ and 13 for enclosed and interstitial grains respectively; uncertainty is standard deviation). By comparison, the compositional range of Chassigny pyrrhotite extends to higher Ni contents (2.9 wt. $\%$; Lorand et al., 2018; Fig. 11). NWA 8694 pyrrhotite is intermediate in Ni content between Chassigny pyrrhotite and pyrrhotite of the most magnesian nakhlites (NWA 998; Nakhla; Ni<0.8 wt.\%; Chevrier et al., 2011). Pyrite in NWA 8694 and Chassigny is slightly nickeliferous (0-1 wt.\%); some analyses of NWA 8694 pyrite show Ni contents up to 2.8 wt.\% (Fig. 11).

\subsubsection{Other phases}

Biotite, amphibole and phosphate phases are of particular interest because of their anions and the possibility of estimating $\mathrm{H}$ concentrations, and because of the possible presence of $\mathrm{Fe}^{3+}$. Analyses are given in Tables $2 \mathrm{a}$ and 4 .

NWA 8694 contains Mg-rich biotite (approximately $\mathrm{Phlog}_{75} \mathrm{Ann}_{25}$ with fairly low halogen content) in both melt inclusions and interstitial trapped melt. Although biotite ionic substitutions are particularly complicated (Dymek, 1983) this biotite seems to be close to stoichiometric with nominal valences, except for a deficiency of $\mathrm{K}$ in the interlayer site. Structural formulae calculated on an eleven anion basis, and on a seven cation basis ("Y", with $\mathrm{K}$ excluded), give very similar results: $\mathrm{K}_{0.85} \mathrm{Y}_{6.98} \mathrm{O}_{11.00}$ and $\mathrm{K}_{0.85} \mathrm{Y}_{7.00} \mathrm{O}_{11.03}$. Halide concentrations are higher in the interlayer site in the interstitial phlogopite than in the melt inclusion biotite (Fig. 12), with $\left(\mathrm{X}_{1.67} \mathrm{~F}_{0.25} \mathrm{Cl}_{0.08}\right)^{2-}$ versus $\left(\mathrm{X}_{1.88} \mathrm{~F}_{0.10} \mathrm{Cl}_{0.02}\right)^{2-}$. Considering the errors in EMP analysis there is no justification for calculating Fe ${ }^{3+}$. Ti contents are lower than in the other chassignites (Johnson et al., 1991, He et al., 2013), higher in interstitial biotite (0.2-3.8 $\mathrm{wt} \%$ ) than in melt inclusion biotite, and not correlated with any excess positive charge. The missing component $\mathrm{X}$ in the anion site is therefore likely to be entirely $\mathrm{OH}^{-}$.

Amphibole in a melt inclusion is shown in Fig 2c. Its structural formulae derived on a 23 oxygenequivalent basis can be written as $\left(\square_{0.31} \mathrm{Na}_{0.65} \mathrm{~K}_{0.04}\right)_{1.00}\left(\mathrm{Ca}_{1.81} \mathrm{Na}_{019}\right)_{2.00}\left(\mathrm{Mg}_{2.30} \mathrm{Fe}_{1.67} \mathrm{Mn}_{0.04} \mathrm{Ti}_{0.35} \mathrm{Cr}_{0.01} \mathrm{Al}_{0.70}\right)_{5.07}\left(\mathrm{Si}_{5.96} \mathrm{Al}_{2.04}\right)_{8.00} \mathrm{O}_{22}\left(\mathrm{X}_{1.58} \mathrm{~F}_{0.31} \mathrm{Cl}_{0.11}\right)_{2.00}$ (where the $\square$ denotes vacant $\mathrm{A}$ sites). The $\mathrm{OH}$ content of amphibole is difficult to define from stoichiometry, and the history of other chassignite amphiboles is complex (Watson et al., 1994; McCubbin et al., 2010; Giesting et al., 2015). The amphibole in NWA 8694 may be moderately OH-rich, and it is close to pargasite in composition. The phosphate found in the interstitial melt is $\mathrm{Cl}$-rich fluorapatite (Table 3) $\mathrm{Ca}_{4.77} \mathrm{~A}^{*}{ }_{0.10}\left(\mathrm{P}, \mathrm{SiO}_{4}\right)_{3.00}\left(\mathrm{~F}_{0.62} \mathrm{Cl}_{0.31} \mathrm{X}_{0.07}\right)_{1.0}$ using a $3 \mathrm{P}+\mathrm{Si}$ ion basis, where $\mathrm{A}^{*}$ is other cations and the missing fraction $\mathrm{X}$ is assumed to be $\mathrm{OH}^{-}$. Baddeleyite contains significant $\mathrm{Nb}$, Th and $\mathrm{U}$, as indicated by their EDS spectra (no WDS analysis).

\subsection{Whole rock and mineral geochemistry}

Whole rock chemical analyses are provided in Tables 6 and 7. As accurate bulk $\mathrm{SiO}_{2}$ contents are difficult to obtain with available instrumental techniques, we used instead a modal recombination of $\mathrm{EMP}^{\mathrm{data}}$ for $\mathrm{SiO}_{2}$ in both Florida LA-ICP-MS and Plouzané ICP-AES analyses for NWA 8694 and Chassigny for $\mathrm{SiO}_{2}$ and recalculated the Florida data downwards to reflect the new analytical total of the major elements. This brought the major elements, especially $\mathrm{Fe}$ and $\mathrm{Mg}$ into agreement. Incompatible trace element concentrations remain higher in the Florida bulk composition (like those of the chassignite NWA 2737) than in the Plouzané data set (like those of Chassigny). 
LA-ICP-MS data for individual phases (olivine, pigeonite and mesostasis) in NWA 8694 and Chassigny are given in Tables 7 and S2. The trace element abundance patterns for bulk chassignites and mesostasis-rich nakhlites (Jambon et al., 2016) are closely parallel (Fig. 13). For clarity, we omit mesostasis-poor nakhlites, which have trace element abundances intermediate between those of chassignites and mesostasis-rich nakhlites (Udry and Day, 2018).

The Rare Earth Element (REE) concentrations are shown in Fig. 14 along with bulk compositions. Intercumulus material has a heterogeneous distribution, as seen in Figure 2. Modal analysis of three polished sections showed different proportions of intercumulus material. and the apparent composition of mesostasis ranges from basaltic trachyandesite to trachyte. We therefore interpret the differences in the two bulk analyses (and in the other two chassignites) as due to different abundances of trapped liquid component.

Augite, chromite, and apatite are too small for easy analysis by laser. We calculated an apparent bulk composition from olivine, pigeonite, and mesostasis abundances and compositions. Compared to the true bulk composition, there is a deficiency in $\mathrm{P}$ and REE. We calculated that the concentration of $\mathrm{P}_{2} \mathrm{O}_{5}$ corresponds to $0.14 \%$ apatite. We assumed that this apatite contains all the REE unaccounted for. This gives an REE (Fig. S5) pattern for the missing phase close to that of Chassigny apatite (Wadhwa and Crozaz, 1995). Table 6. Whole rock analyses of three chassignites by atomic emission spectroscopy ((AES) and sector field mass spectrometry (SFMS).

REE in average Chassigny olivine exhibit a V-shaped pattern enriched in both the light and the heavy REE (LREE and HREE) relative to Sm and Eu (Fig. 14a), while the average NWA 8694 olivine composition exhibits a classic olivine pattern with higher HREE than light REE. A slight uptick at La is visible. The REE patterns of pyroxenes from NWA 8694 exhibit a classic "humped" pattern of clinopyroxene with a prominent negative Eu anomaly, and heavy REE higher than bulk NWA 8694 REE abundances. Despite the different Fe/Mg ratios of the three chassignites, the REE concentrations of pigeonite show some overlap (Fig. 14a). The slope of the HREE pattern is steeper for two Chassigny pyroxene analyses than for five pigeonites in NWA $8694:(\mathrm{Gd} / \mathrm{Lu})_{\mathrm{CI}}$ of $\sim 3 \mathrm{vs}$. 1. LREE concentrations for NWA 8694 and Chassigny mesostasis have similar values to those of nakhlite bulk and mesostasis (Jambon et al., 2016), but their slope is steeper (Fig. 14c).

The abundance of Be correlates with that of $\mathrm{Al}_{2} \mathrm{O}_{3}$ (Fig. 15), $\mathrm{Na}_{2} \mathrm{O}$ (and other alkalis). Beryllium behaves moderately incompatibly with the lowest concentrations in olivines, then pyroxenes and the highest concentrations in mesostasis (Fig. 15). The correlation is weaker in the interstitial material where the concentrations of both Be and $\mathrm{Al}_{2} \mathrm{O}_{3}$ (or $\mathrm{K}_{2} \mathrm{O}$ ) are highest, with a lower Be/Na ratio in NWA 8694 interstitial material than in Chassigny. The correlation between $\mathrm{Be}$ and other incompatible elements is weakened by the crystalline nature of the mesostasis. Boron exhibits a similar behavior to $\mathrm{Be}$ (Fig. 15). Boron abundances correlate with $\mathrm{Al}_{2} \mathrm{O}_{3}$ in olivines and pyroxenes from both Chassigny and NWA 8694 with the highest concentrations in the mesostasis but the correlation is no longer evident for mesostasis analyses (Fig. 15). The tendency of incompatible element correlations to fall apart in analyses of the mesostasis does not allow us to infer that B was lost by outgassing.

\section{DISCUSSION}

\subsection{Comparison of NWA 8694 to Chassignites and Nakhlites}

Ferroan chassignite NWA 8694 has the lowest olivine and chromite contents, and the $\mathrm{r}$ igh 2 st pyroxene content of the three chassignites. Its low olivine content allows small pockets with isolated olivine grains giving a local orthocumulate texture. Phase compositions indicate a more evolved parent liquid than for the other chassignites. Mafic phases in NWA 8694 are the most fractionated among the chassignites. Its olivine has the lowest $\mathrm{Mg}$ and $\mathrm{Ni}$ contents; its chromite has the lowest $\mathrm{Cr}$ contents; its pyroxene the lowest $\mathrm{Mg}$; and its amphibole the lowest $\mathrm{Mg}$ and $\mathrm{Ti}$ contents. Interstitial feldspar compositions are a little less calcic and more potassic than in the Chassigny (Fig. 5a), ranging from oligoclase $\mathrm{An}_{27}$ up to sanidine Or ${ }_{79}$. Both NWA 8694 and Chassigny show sulfides enclosed inside olivine-hosted melt inclusions, and intercumulus sulfides_but_sulfides in NWA 8674 are 
richer in $\mathrm{Fe}$ than those in Chassigny. The amphibole in melt inclusions is more ferroan and richer in $\mathrm{Cl}$ than in the other chassignites, though $\mathrm{F}$ has similar concentration ranges in all three.

Chassigny and NWA 2737 are weakly and strongly shocked, respectively (Floran et al., 1978; Johnson et al., 1991; Langenhorst and Greshake, 1999; Beck et al., 2006; Treiman et al., 2007; He et al., 2013) and fracturing in NWA 8694 olivine resembles that in Chassigny implying that it shares the same shock levels as Chassigny. The same main sulfide phases (pyrrhotite, pyrite, pentlandite) identified in the Chassigny meteorite (Floran et al., 1978; Lorand et al., 2018) were also preserved in NWA 8694. The pyrite shows planar fractures consistent with weak shock (Lorand et al., 2015). NWA 2737 also shows sulfides in similar amount as in Chassigny and NWA 8694 meteorites. However, the strong shock event that liberated NWA 2737 from Mars deeply altered its igneous and hydrothermal sulfides in an assemblage of troilite and Fe-Ni metal (Lorand et al., 2012).

NWA 8694 has some properties closer to those of nakhlites than those of the other chassignites: its olivine composition $\mathrm{Fo}_{54}$ (Fig. 4) approaches that of the least equilibrated nakhlites with a maximum of $\mathrm{Fo}_{45}$ in $\mathrm{NWA} 817$ (Udry and Day, 2018); its augite composition ( Fig. 5, 6, 14) overlaps with those of the most magnesian nakhlites (Friedman-Lentz et al., 1999; Treiman, 2005; Treiman and Irving, 2008; Udry and Day, 2018) and all other nakhlites have augite cores with very similar composition. Specifically, some Lafayette and NWA 998 points (Treiman and Irving, 2008; Udry and Day, 2018) coincide at $\mathrm{En}_{41-40} \mathrm{Wo}_{38-39}$ with analyses from NWA 8694. The heavily overlapping adjacent points in Fig. 5 are due to the most magnesian augite in five other nakhlites (Udry and Day, 2018); the minor element concentrations of these augites also overlap (Fig. 6). The minor elements in augite as a function of $\mathrm{Ca}$ also show a partial overlap between chassignites and augite cores in some other nakhlites (Udry and Day, 2018), as shown in Fig. 6. Major element compositions of NWA 8694 and Chassigny plagioclase and sanidine (Fig. 8a) are like those in nakhlite mesostases (Bunch and Reid, 1975; Jambon et al., 2016).

However most pyroxene rims in nakhlites are more ferroan: the more fracti wa ed nakhlites show a much wider range of minor element concentrations in pyroxene, off the scale of this figure . $\mathrm{Al}$ and $\mathrm{Ti}$, and reaching much lower $\mathrm{Cr}$ values. The partial overlap in Fe/Mg in augite (Fig. 5) indicates very similar compositions for late interstitial melt in NWA 8694 and parental melt of the most primitive nakhlites. The partial overlap in minor elements (Fig. 6) for all chassignites and NWA 998 and Lafayette also indicate melt similarities at the stage of last and first augite crystallization, respectively, in their two hosts. The increases in the incompatible Al and Ti in most nakhlite augite, and the decrease in its compatible $\mathrm{Cr}$ show extensive fractional crystallization of a liquid like late chassignite interstitial liquid. Major element compositions of NWA 8694 and Chassigny mesostasis plagioclase and sanidine (Fig. 8a) are like those in nakhlite mesostases (Bunch and Reid, 1975; Jambon et al., 2016); The bulk composition of NWA 8694 mesostasis corresponds to basaltic trachyandesite to trachyte (Tables 7, S4), like the alkaline melt inclusions in the MIL 03346 nakhlite (Day et al., 2006). In addition, Chassigny, NWA 8694, and nakhlites have similar incompatible element concentrations in their mesostases (Fig. 13, 14).

Chassignites and nakhlites have long been known to have similar ages and patterns of trace element distributions (e.g. Wadhwa and Crozaz, 1995; Beck et al., 2006). Here we have shown that mineral (other than cumulus olivine and chromite) and mesostasis compositions of NWA 8694 are similar to those of nakhlites. This confirms previous conclusions that chassignites and nakhlites are genetically related rocks derived from the same mantle source (Wadhwa and Crozaz, 1995; Beck et al., 2006; Udry and Day, 2018), and is consistent with the invasion of both chassignite intercumulus liquids and nakhlite parent magma with Cl-rich fluids (McCubbin et al., 2013). Thus the parent liquid of NWA 8694 must be closely related to nakhlite liquids. We explore below whether fractional crystallization of model parent liquids, magnesian or nakhlitic, can yield olivine and late liquid of the compositions seen in NWA 8694.

\subsection{Crystallization modeling}

\subsubsection{Magnesian parent Liquids}

Udry and Day (2018) showed that subtraction of $12-15 \%$ olivine and 2-5\% pyroxene from a chassignite parent magma with $15 \mathrm{wt} \% \mathrm{MgO}$ would produce a composition like that of the most primitive nakhlites. This magma would resemble a depleted basaltic komatiite, except in being more ferroan. The subtraction model suggests that fractional crystallization could produce the chassignites and the nakhlites from a single magma, which appears 
to be consistent with trace element similarities. The complexities of modeling crystallization of martic compositions are well known (e.g. Stockstill et al., 2005; Udry et al., 2014) and the three chassignites e an extensive range of olivine composition, from $\mathrm{Fo}_{79}$ to $\mathrm{Fo}_{53}$. We have found that PETROLOG (Danyushevsky and Plechov, 2011) can explain the formation of shergottite NWA 10414 (Hewins et al., 2019). We use it here to see whether proposed chassignite parent melts could crystallize olivine and late liquid of the compositions found in NWA 8694.

The PETROLOG program calculates pseudo-liquidus temperatures using mineral-melt equilibria models for all possible minerals. We used the optional models of Sack et al. (1980) for melt oxidation state and Ariskin et al. (1993) for silicate mineral-melt equilibria, with a variable $\mathrm{K}_{\mathrm{D}}$ for olivine/melt Fe/Mg partitioning, ranging between 0.32 and 0.35 during crystallization. Calculated pseudo-liquidus temperatures are compared to determine which phase(s) should crystallize.

We first evaluated the reconstructed parental melt composition of melt inclusions in olivine in NWA 2737 termed A\# with $12.1 \% \mathrm{MgO}$ (He et al., 2013) to see whether it could crystallize the olivine of all three chassignites. Fractional crystallization of NWA $2737 \mathrm{A \#}$ at 1 bar starts at $1335^{\circ} \mathrm{C}$ and produces $21 \%$ olivine $\mathrm{Fo}_{79-64}$, and at $5 \mathrm{~kb}$ $11 \%$ olivine/ $\mathrm{FO}_{79-73}$, with an oxygen fugacity relative to the fayalite-magnetite-quartz oxygen buffer of FMQ -1 log units. Augite appeared too early for the ferroan composition of NWA 8694 olivine to be achieved. Similar results were obtained with many other proposed parent liquids, e.g. for Chassigny parent A* (Johnson et al., 1991) we found $\mathrm{Fo}_{68-61}$ was crystallized, again falling well short of NWA 8694 olivine. Clearly a more complex process than fractionation of a single magma is needed to produce the range of chassignite olivine compositions stretching to $\mathrm{Fo}_{53}$ and the even more ferroan olivine in nakhlites. Given the prevalence of multiple magma chambers and mush zones under large volcanoes, mixing of primitive and fractionated liquids is likely, as well as contamination by wall rocks. We therefore turned our attention to liquids with closer affinities to NWA 8694.

\subsubsection{Nakhlitic parent liquids}

We considered the NWA 8694 interstitial mesostasis analyses with added olivine as a possible parent melt, but this composition failed to produce sufficiently alkaline daughter liquids, probably because the mesostasis analyses are not representative of the liquid (Hewins et al., 2017). Bearing in mind the number of similarities between nakhlites and chassignites, as well as their alkaline nature (Prinz et al., 1974; Floran et al., 1978; Day et al., 2006; Nekvasil et., 2007; Udry and Day, 2012; Barrat and Bachèlery, 2019) we considered more alkaline parent liquids with nakhlite affinities.

In Fig. 14, we show four bulk REE patterns for the three chassignites along with nakhlite bulk and mesostasis compositions (Jambon et al., 2016). Note that the four patterns for chassignites are nearly parallel, and reflect different quantities of trapped liquid. The chassignite patterns show a strong resemblance to those of nakhlite mesostases and bulk nakhlites. LREE contents of the NWA 8694 mesostasis liquids (as shown in Fig. 14) overlap with those of trace-element-rich nakhlites NWA817, MIL03346 and NWA5790 (Jambon et al., 2016), rather than those of trace-element-poor nakhlites (Udry and Day, 2018), though the HREE appear to be affected by undersampled carrier phases, as discussed above. In a search for a parent for NWA 8694, we selected a relatively $\mathrm{Na}$ - and K-rich nakhlite reheated melt inclusion composition with intermediate silica, NA01a of Stockstill et al. (2005). This composition (Table 7) did indeed produce relatively alkaline daughter liquids with PETROLOG (Fig. 16) at FMQ-1, based on an estimate of FMQ-1.3 for Chassigny (Floran et al. (1978), and 1 bar, but was not olivinesaturated.

We added Nakhla core olivine (Treiman, 2005) to the NA01a parent in different amounts, to construct a series of olivine-saturated liquid compositions. Modeling of these parent liquids gave olivine compositions overlapping that in NWA 8694 (Fig. 17) and alkaline daughter liquids (Fig. 16). These compositions were crystallized at 1 bar and at $5 \mathrm{~kb}$. The $5 \mathrm{~kb}$ calculations deviated further from NWA 8694 interstitial liquid composition than the corresponding 1 bar calculations, and those runs are not illustrated in the figures. The silica enrichment trend caused by olivine crystallization was reversed when olivine gave way to pyroxene, but continued when pyroxene was joined by plagioclase. The pyroxene was augite, with no pigeonite. The daughter liquids also passed close to NWA mesostasis compositions (Fig. 16), with the composition with 10\% added olivine producing a better match than that with $20 \%$ added olivine. Olivine $\mathrm{Fo}_{54-50}$ formed in the $10 \%$ composition from $1144-1118^{\circ} \mathrm{C}$ at 1 bar, when it was replaced by augite; augite was joined by plagioclase at $1085^{\circ} \mathrm{C}$, and the two phases cocrystallized until the liquid was $80 \%$ solidified at $797^{\circ} \mathrm{C}$. The latter calculated daughter liquids are virtually $\mathrm{Mg}$-free, unlike the 
analyses of trapped liquid in NWA 8694 (Fig. 16), because early magnesian crystals are removed in the calculation whereas they remain in the natural mesostasis (Fig. 2d). Trapped liquids in the cumulate pile would undergo Fe-Mg exchange with cumulate minerals (e.g., Coogan and O'Hara, 2015; Lissenberg and MacLeod, 2016) limiting the extent of the Fe-enrichment achieved compared with a fractional crystallization calculation.

We have satisfied the minimum requirements of a parent magma for NWA 8694, to produce relatively ferroan olivine and alkaline mesostasis, but are far from having a unique solution and a rigorous history for the formation of NWA 8694. Nevertheless, we have identified a liquid composition capable of producing chassignitelike cumulates and nakhlite-like daughter liquids. The strong relationship between chassignites and nakhlites is supported, in particular in the similar alkaline nature of mesostases (Day et al., 2006).

\subsection{Trace Element Geochemistry}

\subsubsection{REE of mesostasis and possible parental liquids}

The close parallelism between incompatible trace element abundance patterns for bulk chassignites and mesostasis-rich nakhlites (Fig. 13) indicates a close genetic relationship, in which crystal fractionation must have played a role (this work, Beck et al., 2006, Jambon et al., 2016). The REE patterns for olivine indicate that small melt inclusions (enriched in LREE) are ubiquitous in the large $(50-100 \mu \mathrm{m})$ spots used to analyze REE in the olivines in Chassigny, but are significantly less in olivine from NWA 8694.

Mesostasis constitutes $\sim 5 \%$ of the bulk rock, based on incompatible element ratios such as $\mathrm{La} / \mathrm{Yb}$ and $\mathrm{Gd} / \mathrm{Yb}$. As we have $\sim 4 \%$ modal feldspar, this indicates that most of the pyroxene ( $9 \%)$ is adcumulate in origin. The analyses of the interstitial material exhibit compositio tat heterogeneity that is more complex than could be produced solely by fractional crystallization. It was shown that .... rue composition of Chassigny interstitial material was difficult to determine owing to the impossibility of avoiding the surrounding mafic silicates, but it shows significant enrichment of lithophile incompatible elements, including REE. The NWA 8694 interstitial material shows less contamination by mafic silicates, reaching extremely low $\mathrm{MgO}$ contents $(<1 \mathrm{wt} . \%)$, but some analyses exhibit strong plagioclase or phosphate signatures (Fig. 14b).

Bulk REE concentrations result from the mixing of mafic silicates with average mesostasis, but mesostasis exhibits great variations in REE contents. The plagioclase-dominated patterns of NWA 8694 mesostasis are low in REE abundance and exhibit large positive Eu anomalies, with Eu/Eu* of 40-100. Fig. 18 is a plot of the Eu anomaly against the CI-normalized La abundance ( $\left.\mathrm{La}_{\mathrm{CI}}\right)$ for the interstitial material and shows a mixing curve between phosphate-dominated mesostasis analyses at the high $\mathrm{La}_{\mathrm{CI}}$ end with slightly negative $\mathrm{Eu}$ anomaly, and low $\mathrm{La}_{\mathrm{CI}}$ with large positive Eu anomalies for the plagioclase-rich analyses. A few of the Chassigny interstitial material compositions plot along the correlation defined by the NWA 8694 mesostasis analyses, but most of the Chassigny analyses plot away from the mixing curve towards the bulk and olivine+pyroxene points at lowest $\mathrm{La}_{\mathrm{CI}}$ with small negative Eu anomalies. Fig. 18 shows that most of the NWA 8694 mesostasis patches (black diamonds) are mixtures of plagioclase and phosphate, which probably crystallized from the interstitial liquid. The average REE pattern is matched by a mixture of $96 \%$ plagioclase and $4 \%$ apatite from NWA 2737 for La-Gd (Fig. S5), while HREE were below the detection limit in plagioclase (Beck et al., 2006). Measurements of the bulk NWA 8694 composition exhibit small negative Eu anomalies. We note that most Chassigny mesostasis points but only a few NWA 8694 points plot close to the Nakhla parental magma composition (Treiman, 2005) in Fig. 18. The latter exhibits no Eu anomaly and has a $(\mathrm{La} / \mathrm{Yb})_{\mathrm{CI}}$ ratio of 6 , similar to the $(\mathrm{La} / \mathrm{Yb})_{\mathrm{CI}}(5-7)$ of mesostasis compositions for nakhlites NWA 5790, NWA 817, and MIL 03346 (Jambon et al., 2016). The dispersion of the NWA 8694 points in Fig. 15 is a challenge in searching both for chassignite relationships and for parent magma compositions.

\subsubsection{Processes modifying trace element distributions}

The LREE concentrations in mesostasis in NWA 8694 are similar to those of Chassigny and nakhlites (Treiman, 2015), consistent with a fractionation relationship, although the HREE are difficult to explain. Curiously, the interstitial material in both Chassigny and NWA 8694 has strongly sloping REE patterns (Fig. 14c) that exhibit a higher $(\mathrm{La} / \mathrm{Yb})_{\mathrm{CI}}$ ratio than that of nakhlites (8-17 in Chassigny interstitial material; 48-103 in NWA 8694 interstitial material; Fig. 18). Even the phosphate-dominated mesostasis analysis from NWA 8694 has a $(\mathrm{La} / \mathrm{Yb})_{\mathrm{CI}}$ of 74 and its REE pattern is parallel to those of the other NWA 8694 interstitial patches. Thus, fractional crystallization within the NWA 8694 mesostasis appears not to have changed the slope of the REE pattern. If these interstitial patches are the 
last dregs of the crystallizing magma, then interstitial material from Chassigny more closely resembles nakhlite mesostasis, and hence a nakhlite parental magma: the late liquid in NWA 8694 has a more strongly sloping REE pattern than probable nakhlite parental melt compositions by about an order of magnitude. Very few processes can fractionate heavy REE (HREE) during fractional crystallization. Neither pyroxene nor olivine removal could remove enough of the HREE to increase the slope of the REE pattern that significantly. A phase high in HREE relative to melt that possibly could be invoked is zircon, but removal of zircon would also lower the $\mathrm{Zr}-\mathrm{Hf}$ abundances, which is not observed. Some HREE-rich mesostasis phases, baddeleyite and zirconolite, are attached to the surrounding olivine, and are therefore undersampled in the laser spot on plagioclase-rich mesostasis areas. This undersampling explains the steep REE pattern, as baddeleyite (1\%)-mesostasis mixtures give less steep patterns resembling nakhlite mesostasis (Fig.S6).

With the discovery of the second chassignite, NWA 2737, olivine fractionation from parental melt(s) appeared to be the major process influencing chassignite compositions (Beck et al., 2006). Other igneous processes e.g. different degrees of melting of the same source seen for nakhlites and hotspot basalts (Goodrich et al., 2013; Vlastélic et al., 2018), trapping of different amounts of liquid (Barrat and Bartélery, 2019), and migration of mesostasis liquid (Treiman, 2005) could also have influenced melt compositions. In addition, a series of interactions with the exterior, e.g. assimilation (Humayun et al., 2020), fluid infiltration (McCubbin et al., 2013; Nagao et al., 2019) and outgassing (Yang et al., 2019) have been shown to modify chassignite compositions. Fig. 19 shows the incompatible element abundances for the interstitial material plotted on a Martian mantle-normalized plot (Yang et al., 2015) with elements organized according to decreasing incompatibility from left to right. Difficulties may arise from the heterogeneity and small size of mesostasis patches, and overlap on melt inclusions and other phases for olivine and pyroxene. For example, positive anomalies in $\mathrm{Ba}$ and $\mathrm{Sr}$ in the mesostasis patches are likely due to plagioclase oversampling (Fig. 19), while the steep slope of their REE (high La/Yb) seen in Figs. 14 b and 19 may be due to undersampling of baddeleyite or oversampling of phosphate. However, other processes must be involved, as we see poor correlation between $\mathrm{Cs}$ (and $\mathrm{Tl}$ ) and $\mathrm{Rb}$ (Table 7, S2) for the interstitial material with the highest $\mathrm{Rb}$ contents even though $\mathrm{K}, \mathrm{Rb}, \mathrm{Tl}$ and $\mathrm{Cs}$ are likely to be in the same phases. Here we discuss the roles of fractional crystallization versus other processes on trace element distribution during the formation of NWA 8694.

\section{Fluids}

McCubbin et al. (2013) argued that chassignites and nakhlites were invaded by Cl-rich fluids after crystallization of the cumulus phases. Bellucci et al. (2016) showed that radiogenic $\mathrm{Pb}$ was introduced into Chassigny minerals by surface fluids entering fractures that were subsequently annealed. Hydrothermal fluids operated pervasively in Chassigny (Lorand et al., 2018) and in NWA 8694 as shown_by magmatic sulfides that were converted to pyrite. We cannot demonstrate trace element modification by fluids, but Nagao et al. (2019) showed from noble gas data that NWA 8694, like the MIL nakhlites, had interacted with surface fluids.

\section{Fractional crystallization}

The most highly incompatible elements (Cs-Nd) are concentrated by factors of 25 in NWA 8694 and Chassigny mesostasis (Fig. 19), as well as in nakhlite mesostasis, relative to the martian mantle. The bulk NWA 8694 composition plots close to martian mantle abundances (Yang et al., 2015) for Cs-Nd, with the exception of excesses of $\mathrm{Tl}$ and $\mathrm{U}$. The abundances of these two elements might be increased by terrestrial alteration in the desert (known for U), but five spot analyses of pyroxene from NWA 8694 also exhibit positive Tl and U anomalies (Fig. 16) indicating that strong separation of $U$ and $\mathrm{Tl}$ is a feature of pyroxene accumulation. Anomalies in $\mathrm{Tl}$ and $\mathrm{U}$ are not seen in the mesostasis, indicating that pyroxene fractionated from the parental melt but that mesostasis crystallization cannot account for their compositions.

Thorium and $U$ are highly incompatible elements, with $U$ being slightly preferred over Th in the lattice of clinopyroxene (LaTourette and Burnett, 1995). The Th/U ratio is systematically low in olivines $(<0.2)$ from both Chassigny and NWA 8694, implying that some $U$ is present in the olivine lattice, while Th is near the detection limit (Table7 and S2). The Th/U ratio is $\sim 2$ in pyroxenes from Chassigny and even lower $(<0.5)$ in pyroxenes from NWA 8694, consistent with experimental constraints for Th-U partitioning in low-pressure pyroxenes (LaTourette and Burnett, 1995). The Th/U ratio is systematically higher in NWA 8694 mesostasis (5.1) than in Chassigny interstitial material (3.9). Nakhlites are known to exhibit a superchondritic Th/U ratio ( 4), but NWA 8694 interstitial patches 
are even higher in $\mathrm{Th} / \mathrm{U}$ than any nakhlite. These observations suggest that nakhlitic liquid crystallized pyroxene in NWA 8694 and evolved to mesostasis composition.

Bulk NWA 8694 and NWA 8694 interstitial material also exhibit a small deficiency of Nb-Ta and of Zr-Hf (Fig. 19. The Zr-Hf deficiency is also observed in Chassigny interstitial material to a lesser degree. These Nb-Ta-ZrHf deficiencies point to Fe-Ti oxide crystallization since pyroxene from NWA 8694 also exhibits the Zr-Hf deficiency. Ilmenite is an accessory phase in interstitial mesostasis, as are the undersampled baddeleyite and a few $\mathrm{Nb}$ - and Th-rich $\mathrm{Ca}-\mathrm{Ti}-\mathrm{Zr}$ microphases, notably zirconolite, that explain the slope of the REE pattern.

\section{Outgassing}

The concentrations of $\mathrm{Ge}$ and $\mathrm{Zn}$ in the olivine and pyroxene in chassignites and nakhlites appear to be controlled by fractional crystallization (Yang et al., 2019). However, olivine, pyroxene, and mesostasis in NWA 8694 have lower Ge than expected from its incompatible nature (Table 7). The Ge/Si ratio is relatively constant in the martian mantle (Yang et al., 2015). The Ge contents ( 2.5 ppm) and Ge/Si ratios of Chassigny interstitial material are similar to those of bulk chassignites, but the NWA 8694 interstitial material is depleted in Ge ( 0.6-0.8 ppm). Melting of a more garnet-rich source for NWA 8694 interstitial material could explain both the higher $(\mathrm{La} / \mathrm{Yb})_{\mathrm{CI}}$ and the lower Ge/Si ratios observed, but for the Ge/Si ratio this depletion is still larger than expected. Magmatic outgassing has been shown to lower Ge/Si ratios in shergottites (Yang et al., 2019) to values similar to that observed in NWA 8694 interstitial material. Thus, a late-stage outgassing of the melts from which NWA 8694 mesostasis was trapped, or a distinct magmatic origin for the interstitial material, is indicated by the Ge-Si systematics. This evidence makes it hard to derive nakhlites by fractional crystallization from the same melt as NWA 8694, and implies that nakhlites and chassignites were derived from multiple magma bodies.

\subsection{Terrestrial Analogues and Geological Setting}

\subsubsection{A single cumulate pile or separate flows}

In plutonic and most hypabyssal rocks pigeonite exsolves augite and inverts to orthopyroxene because of slow cooling (Hess, 1960; Robinson, 1980). The augite lamellae in pigeonite in NWA 8694 are $2 \mu \mathrm{m}$ in apparent width (Fig. 2b), comparable to or a little wider than those in Chassigny (Monkawa et al., 2004), suggesting a nearsurface environment, such as a thick flow, or shallow reservoir, rather than plutonic cooling. The fine plagioclase laths in Nakhla mesostasis also indicate rapid cooling (Treiman, 1986). The reverse zoning of Ca in olivine indicating only partial loss of $\mathrm{Ca}$ (as in Chassigny), the failure of pigeonite to invert, and the fine grain size of the mesostasis, are also inconsistent with emplacement at significant depth. The adcumulate texture of chassignites does, however, indicate slower cooling than for nakhlites, raising the question of mode of emplacement.

Since nakhlites and chassignites have similar ages and trace element abundance patterns, these meteorites must be genetically related, although contextual details are lacking. Different chassignites and nakhlites may represent separate flows or shallow intrusions (Treiman, 1986; Treiman, 2005), but the idea of a single body for all nakhlites has been widely explored (Mikouchi et al., 2003; Day et al., 2006). The nakhlites and chassignites have been ordered in terms of Mg\#, extent of zoning, mesostasis content, and cooling rate estimate, to give a sequence within a proposed flow unit or cumulate pile (Mikouchi et al., 2003; McCubbin et al., 2013). However, considering subtle differences between otherwise similar nakhlites, and the probability of a series of eruptions from a complex long-lived sub-volcanic zone, it is unlikely that all these rocks fit in a single flow unit. Several flows or flow lobes were proposed recently over a short time period (Jambon et al., 2016; Balta et al., 2017; Udry and Day, 2018; Cohen et al., 2017). The similarity of augite core compositions, feldspar compositions, and REE patterns in NWA 8694 and in nakhlites, suggest a close genetic relationship such as derivation from the same source. However, we have shown here from the Ge/Si ratios that they could not have formed from the same melts. They may differ in that nakhlites were emplaced at depth or extruded promptly (no degassing based on Ge/Si systematics) while NWA 8694 accumulated from a melt that outgassed in the caldera of a volcano.

\subsubsection{Archean komatiite-tholeiite association}

The associated chassignites and nakhlites have been compared to terrestrial volcanic rocks: they are reminiscent of the association of Archean komatiites and tholeiites (Arndt et al., 1977; Friedman-Lenz et al., 1999). Tholeiitic rocks in Munro Township include layered dunite-pyroxenite flows like Theo's Flow, where the augite cumulate layer is very similar to nakhlite (Friedman-Lentz et al., 1999). However, understanding of such flows is 
complicated by the possibility of blanketing of hot flows by subsequent eruptions (Murri et al., 2019), and the underlying olivine layer has an orthocumulate texture (Arndt et al., 1977), not the adcumulate texture as in chassignites. In thin komatiite flows there is also only olivine orthocumulate, but thicker komatiite units (>150 m) have adcumulate lower dunite (B2) zones (Houlé et al., 2002). The proposed parent liquid A\# of the most magnesian chassignite NWA 2737 contains $12.1 \% \mathrm{MgO}$ (He et al., 2013) and a liquidus temperature of $\sim 1335^{\circ} \mathrm{C}$ (this work). Such liquids would be effective at melting surface rocks, causing assimilation, and cutting a channel (Hill et al., 1995). High Sn/Sm contents in NWA 2737 are evidence of such contamination (Humayun et al., 2020). The adcumulate textures of chassignites are like those of layers of adcumulate dunite in thick komatiites that were interpreted as forming as channel fill (Hill et al., 1995; Houlé et al., 2002). Thus chassignites and nakhlites are in some ways analogous to Archean komatiites and tholeiites, though the latter, while spatially related, are not closely genetically related based on trace element data (Arndt, 1991; Rajamani et al., 1989). Moreover, the differences of both olivine compositions and textures make it difficult to place most chassignites and nakhlites in the same flow unit.

\subsubsection{Basaltic shield volcanoes}

Major volcanic centers on Earth include plume-fed shield volcanoes, e.g. on Hawai'i, Ascension, and La Réunion. Dunites have been observed in association with the Piton de la Fournaise volcano on La Réunion. They occur within layered cumulates in low altitude surface exposures and in drill cores from at least $3 \mathrm{~km}$ depth, as well as occurring as xenoliths in basalts (Barrat and Bachèlery, 2019; Babkine et al., 1966). The xenoliths in particular have textures very similar to those of chassignites, and the same crystallization sequence (Udry and Day, 2017; Barrat and Bachèlery, 2019). Barrat and Bachèlery (2019) showed that Chassigny had similar relationships in incompatible element distributions between trapped melt inclusions and parent magmas as at Piton de la Fournaise, implying in both cases a close relationship. The feldspar in NWA 8694 and nakhlites has a similar range to those of alkaline and nephelinic lavas from shield volcanoes on Maui (Keil et al., 1972), though lacking calcic phenocrysts. The alkaline nature of melt inclusions in Nakhla (Day et al., 2006) and Chassigny (Nekvasil et al., 2007) also makes an origin from shield volcanoes more likely than origin from a komatiite-tholeiite association.

Magma is understood to crystallize within solidification fronts on magma chamber walls (Marsh, 1996), and in the case of Piton de la Fournaise dendritic olivine forms harrisitic mush zones on the cold walls (Welsch et al, 2013). Erupting liquid can tear olivine from the fragile mush zone giving olivine-rich lavas. As such picrite flows are found on the flanks of Piton de la Fournaise at low elevations, they must come from depth in the complex magma reservoir, while evolved liquids including trachyte erupt from the summit (Famin et al., 2009). Similar processes could occur in the case of chassignites, with a nakhlitic liquid rising through the olivine mush. Though dunites occur as cumulate layers and xenoliths in shield volcanoes, major flows could also conceivably develop adcumulate dunites, as in the komatiite case.

Dating of six nakhlites using the ${ }^{40} \mathrm{Ar} /{ }^{39} \mathrm{Ar}$ method defined at least four discrete events over a time period of $93 \pm 12$ Ma between 1416 and 1322 Ma consistent with a plume-fed volcano (Cohen et al. 2017). This duration is well over an order of magnitude longer than for shield volcanoes on Earth. The long history and the general large size of martian volcanoes give opportunities for processes such as crystal fractionation, assimilation, recharge and magma mixing to occur. Treiman and Irving (2008) argued that intercumulus magma moved through and was expelled from the augite cumulate of the nakhlite NWA 998. Goodrich et al. (2013) showed that two different liquids are trapped as melt inclusions in Nakhla, a Si-rich melt in augite representing the Nakhla parent magma; and a Si-poor more primitive liquid that crystallized the olivine. The two liquids could have resulted from different degrees of melting of the same source at different depths. Goodrich et al. (2013) concluded that the

Nakhla parent liquid rose through the olivine cumulates formed from the earlier Si-poor magma, incorporating olivine crystals. The parent liquids proposed for NWA 2737 (He et al. 2013) and for Chassigny (Johnson et al., 1991) are such Si-poor liquids, while we have modified a Nakhla parent liquid (Stockstill et al., 2005 ) to yield a less Si-poor parent capable of yielding the olivine and alkaline mesostasis of NWA 8694. The similarities of augite, feldspar, and mesostasis compositions between NWA 8694 and nakhlites are consistent with chassignites and nakhlites originating in a shield volcano. Based on Ge degassing, NWA 8694 formed from magma that communicated with the surface, in contrast to other chassignites. Eruption from the summit is possible but unlikely from density considerations, and it could have solidified in the feeder pipe. Alternatively it could have formed in the lava pond of a satellitic shield or as cumulates in a thick flow. We illustrate the latter 
possibilities in Fig. 20, which is based on the Piton de la Fournaise volcano (Famin et al., 2009; Welsch et al., 2013; Barrat and Bachèlery, 2019).

\section{CONCLUSIONS}

NWA 8694, the third chassignite, has an olivine composition $\left(\mathrm{Fo}_{54}\right)$ intermediate between those of the other chassignites and nakhlites, and has pigeonite as the dominant pyroxene. Cumulus chromite has a similar composition range to that in Chassigny but it extends to more Fe-Ti-rich compositions. The trachytic mesostasis has feldspar compositions $\left(\mathrm{An}_{27}-\mathrm{Or}_{79}\right.$ ) like those in both Chassigny and nakhlites. NWA 8694 augite is more ferroan than Chassigny augite, but has the same composition $\left(\mathrm{En}_{41-40} \mathrm{Wo}_{38-39}\right)$ as augite cores in the most primitive nakhlites, e.g. NWA 998. The igneous pyrrhotite is also slightly more ferroan $((\mathrm{Fe} / \mathrm{Fe}+\mathrm{Ni})$ at. $=0.98)$ compared to Chassigny pyrrhotite $((\mathrm{Fe} / \mathrm{Fe}+\mathrm{Ni})$ at. $=0.97)$. Mineralogically NWA 8694 constitutes a direct link between the chassignites and the nakhlites.

The bulk REE patterns of the three chassignites have the same shape as those of nakhlite mesostases, and like nakhlite mesostases, have Cs-Nd levels $\sim 25 \mathrm{x}$ chondrites, suggesting a nakhlitic parent magma. However, the REE pattern of interstitial material in NWA 8694 is steeper than all other chassignite or nakhlite patterns, which can be explained by undersampling of baddeleyite and zirconolite that occur at olivine contacts with mesostasis. Positive $\mathrm{Tl}$ and $\mathrm{U}$ anomalies in pyroxene indicate fractional crystallization of pyroxene in NWA 8694 from its parent magma, but mesostasis is unfractionated. $\mathrm{Th} / \mathrm{U}$ ratios in mesostasis are highly enriched compared to nakhlites.

Major element compositions of chassignites and Ge contents of olivine and pyroxene are consistent with crystal fractionation of olivine, chromite and pyroxene from closely related magma compositions. However, Ge-Si systematics indicate a late-stage outgassing of the melts from which NWA 8694 mesostasis was trapped, or a distinct magmatic origin of the interstitial material.

Proposed parent melt compositions such as NWA 2737 A\# with 12.1\% MgO (He et al., 2013) cannot produce olivine as ferroan as in NWA8694 by fractional crystallization, showing a more complex process is required, e.g. different degrees of partial melting or magma mixing. Olivine and potassic late liquid of the compositions observed in NWA 8694 are produced by model crystallization of a nakhlite parent liquid NA01a (Stockstill et al., 2005) with 10\% added Nakhla olivine.

As all chassignite olivine cannot be produced by fractionation of a single liquid, chassignites and nakhlites cannot be crystallized together in a closed system like a single thick lava flow. Chassignites and nakhlites formed as flows or hypabyssal intrusions with entrained olivine and augite crystals. They show textural and geochemical similarities to cumulates and basalts of the terrestrial shield volcano on La Réunion (Barrat and Bachèlery, 2019), where later eruptions appear to have removed crystals from the solidification fronts of earlier more magnesian magmas.

Acknowledgments - We are indebted to L. Labenne, for the sample; to M. Fialin and N. Rividi for help with the electron probe; and to M. J. Carr for IGPET and A. Danyushevsy for PETROLOG. We are particularly indebted to R. M. Hewins for drafting Fig. 20. We are grateful for funding from NASA Solar Systems Workings program grant NNX16AP98G (M. Humayun), ANR grant MARS-PRIME ANR-16-CE31-0012 (N. Mangold) and CNES INSU grant 2013-PNP (B. Zanda). The National High Magnetic Field Laboratory is supported by the National Science Foundation through NSF/DMR-1644779 and the state of Florida. 


\section{REFERENCES}

Ali A., Jabeen I., Gregory D., Verish R. and Banerjee, N. R. (2016) New triple oxygen isotope data of bulk and separated fractions from SNC meteorites: Evidence for mantle homogeneity of Mars. Meteorit. Planet. Sci. 51, 981-995.

Ariskin A. A., Frenkel M. Ya., Barmina G. S. and Nielsen R. (1993) COMAGMAT: a FORTRAN program to model magma differentiation processes. Comput. Geosci. 19, 1155-1170.

Arndt N. T. (1991) High Ni in Archean tholeiites. Tectonophysics 187, 411-419.

Arndt N.T., Naldrett A.J. and Pyke D.R. (1977) Komatiitic and iron-rich tholeiitic lavas of Munro Township, northeast Ontario. J. Petrol. 18, 319-369.

Babkine J., Conquéré F. and Vilminot J. C. (1966) Nodules de péridotite et cumulats d'olivine. Bulletin de Minéralogie, 89, 262-268.

Balta B., Sanborn M. E., Mayne R. G., Wadhwa M., McSween, H. Y. Jr and Crossley S. D. (2017) Northwest Africa 5790: A previously unsampled portion of the upper part of the nakhlite pile. Meteor. Planet. Sci. 52, 36-59.

Barrat J. A. and Bachèlery, P. (2019) La Réunion Island dunites as analogs of the Martian chassignites: Tracking trapped melts with incompatible trace elements. Lithos 344, 452-463.

Barrat J.-A., Zanda B., Moynier F., Bollinger C., Liorzou C. and Bayon G. (2012) Geochemistry of CI chondrites: major and trace elements, and $\mathrm{Cu}$ and $\mathrm{Zn}$ isotopes. Geochim. Cosmochim. Acta 83, 79-92.

Barrat J.A., Jambon A., Ferrière L., Bollinger C., Langlade J., Liorzou C., Boudouma O. and Fialin M. (2014) No martian soil component in shergottite meteorites. Geochim. Cosmochim. Acta 125, 23-33.

Barrat J.A., Dauphas N., Gillet P., Bollinger C., Etoubleau J., Bischoff A. and Yamaguchi A. (2016) Evidence from Tm anomalies for non-CI refractory lithophile element proportions in terrestrial planets and achondrites. Geochim. Cosmochim. Acta 176, 1-17.

Beck P., Barrat J. A., Gillet P., Wadhwa M., Franchi I. A., Greenwood R. C., Bohn M., Cotten J., de Moortele B. V. and Reynard B. (2006) Petrography and geochemistry of the chassignite Northwest Africa 2737 (NWA 2737). Geochim. Cosmochim. Acta 70, 2127-2139.

Bellucci J. J., Nemchin A. A., Whitehouse M. J., Snape J. F., Kielman R. B., Bland P. A. and Benedix, G. K. (2016). $\mathrm{A} \mathrm{Pb}$ isotopic resolution to the Martian meteorite age paradox. Earth Planet. Sci. Lett. 433, 241-248.

Bunch T. E. and Keil K. (1971) Chromite and ilmenite in nonchondritic meteorites. Amer. Mineral. 56, $146-157$.

Bunch T. E., and Reid A. M. (1975) The nakhlites Part I: Petrography and mineral chemistry. Meteoritics 10, 303315.

Chevrier V., Lorand J.-P. and Sautter V. (2011). Sulfide petrology of four nakhlites (NWA817, NWA998, Nakhla, Governador Valadares). Meterorit. Planet. Sci. 46, 769-784.

Cohen B.E., Mark D.F., Cassata W.S., Lee M.R., Tomkinson T. and Smith C.L. (2017) Taking the pulse of Mars via dating of a plume-fed volcano. Nature Communications 8, 640.

Coogan L. A. and O'Hara M. J. (2015) MORB differentiation: In situ crystallization in replenished-tapped magma chambers. Geochim. Cosmochim. Acta 158, 147-161. 
Danyushevsky L. V. and Plechov P. (2011) Petrolog3: Integrated software for modeling crystallization processes, Geochem. Geophys. Geosyst. 12, Q07021.

Day J. M. D., Taylor L. A., Floss C. and McSween H. Y. (2006) Petrology and chemistry of MIL 03346 and its significance in understanding the petrogenesis of nakhlites on Mars. Meteorit. Planet. Sci. 41, 581-606.

Dymek R.F. (1983) Titanium, aluminum and interlayer cation substitutions in biotite from high-grade gneisses, West Greenland. Amer. Mineral. 68, 880-899.

Famin V., Welsch B., Okumura S., Bachèlery P. and Nakashima S. (2009) Three differentiation stages of a single magma at Piton de la Fournaise volcano (Reunion hot spot). Geochemistry, Geophysics, Geosystems 10(1)

Floran R. J., Prinz M., Hlava P. F., Keil K., Nehru C. E. and Hinthorne J. R. (1978). The Chassigny meteorites: A cumulate dunite with hydrous amphibole-bearing melt inclusions. Geochim. Cosmochim. Acta 42, 12131229.

Franchi I. A., Wright I. P., Sexton A. S. and Pillinger C. T. (1999) The oxygen-isotopic composition of Earth and Mars. Meteorit. Planet. Sci. 34, 657-661.

Franz H. B., Kim S. T., Farquhar J., Day J. M., Economos R. C., McKeegan K. D., ... and Dottin III, J. (2014) Isotopic links between atmospheric chemistry and the deep sulphur cycle on Mars. Nature 508, 364-368.

Friedman-Lentz R. C., Taylor G. J. and Treiman A. H. (1999) Formation of a martian pyroxenite: a comparative study of the nakhlite meteorites and Theo's Flow. Meteorit. Planet. Sci. 34, 919-932.

Gale N.H., Arden J.W. and Hutchison R. (1975) The chronology of the Nakhla achondrite meteorite. Earth Planet. Sci. Lett. 26, 195-206.

Gattacceca J., Hewins R. H., Lorand J.-P., Rochette P., Lagroix F., Cournède C., Uehara M., Pont S., Sautter V., Scorzelli R. B., Hombourger C., Munayco P., Zanda B., Chennaoui H. and Ferrière L. (2013) Magnetism of a pristine sample from Mars: the Tissint Martian meteorite. Meteorit. Planet. Sci.48. 199-936.

Giesting, P. A., Schwenzer, S. P., Filiberto, J., Starkey, N. A., Franchi, I. A., Treiman, A. H., ... and Grady, M. M. (2015). Igneous and shock processes affecting chassignite amphibole evaluated using chlorine/water partitioning and hydrogen isotopes. Meteorit. Planet. Sci. 50, 433-460.

Goodrich C. A., Treiman A. H., Filiberto J., Gross J. and Jercinovic M. (2013) $\mathrm{K}_{2} \mathrm{O}$-rich trapped melt in olivine in the Nakhla meteorite: Implications for petrogenesis of nakhlites and evolution of the Martian mantle. Meteorit. Planet. Sci. 48, 2371-2405.

He Q., Xiao L., Hsu W., Balta J. B., McSween H. Y. and Liu Y. (2013). The water content and parental magma of the second chassignite NWA 2737: Clues from trapped melt inclusions in olivine. Meteorit. Planet. Sci. 48, 474-492.

Hess H. H. (1960) Stillwater Igneous Complex, Montana, a quantitative mineralogical study. Geological Society of America Memoir 80, 230 pp.

Hewins R. H., Zanda B., Pont S., Humayun M., Assayag N. and Cartigny P. (2015) NWA 8694, a ferroan chassignite. Lunar Planet Sci. XLVI. Lunar Planet. Inst., Houston. \#2249 (abstr.).

Hewins R. H., J.-A. Barrat, M. Humayun, S. Pont and B. Zanda (2017) NWA 8694 and the chassignite parent liquid problem. Lunar Planet Sci. XLVIII. Lunar Planet. Inst., Houston. \#2533 (abstr.).

Hill R. E. T., Barnes S. J., Gole M. J. and Dowling, S. E. (1995) The volcanology of komatiites as deduced from field relationships in the Norseman-Wiluna greenstone belt, Western Australia. Lithos 34, 159-188. 
Houlé M.G., Davis P.C., Lesher C.M. and Arndt N.T. (2002) Extrusive and intrusive komatiites, komatiitic basalt and peperite and ore genesis at the Dundonald Ni-Cu-(PGE) Deposit, Abitibi Greenstone Belt, Canada. 9th International Platinum Symposium Abstract Volume, Billings, Montana, p. 181-184.

Humayun M., Simon S. B. and Grossman L. (2007) Tungsten and hafnium distribution in calcium-aluminum inclusions CAIs from Allende and Efremovka. Geochim. Cosmochim. Acta 71, 4609-4627.

Humayun M., Davis F. A. and Hirschmann M. M. (2010) Major element analysis of natural silicates by laser ablation ICP-MS. J. Anal. At. Spectrom. 25, 998-1005.

Humayun M., Yang S. Righter K. Zanda B. and Hewins R. H. (2016) The germanium dichotomy in martian meteorites. Lunar Planet. Sci. Conf. XLVII. Lunar Planet. Inst., Houston. \#2459 (abstr.).

Humayun M., Yang S., Irving A. J. and Righter, K. (2019) Sulfide assimilation and mineralization in ancient (2.4 Ga) shergottites. (abstract). Meteorit. Planet. Sci. 54 (Suppl.) \#6380.pdf.

Humayun M., Yang S., Irving A. J., Hewins R. H, Zanda B., Righter K. and Peslier A. H. (2020) Tin abundances require that chassignites originated from multiple magmatic bodies distinct from nakhlites. Lunar Planet. Sci. Conf. $51^{\text {st }}$. Lunar Planet. Inst., Houston. \#1338 (abstr.)

Jambon A., Sautter V., Barrat J. A., Gattacceca J., Rochette P., Boudouma O., Badia D. and Devouard B. (2016) Northwest Africa 5790: Revisiting nakhlite petrogenesis. Geochim. Cosmochim. Acta 190, 191-212.

Jochum K.-P., Weis U., Stoll B., Kuzmin D., Yang Q., Raczek I., Jacob D. E., Stracke A., Birbaum K., Frick D. A., Günther D. and Enzweiler J. (2011) Determination of reference values for NIST SRM 610-617 glasses following ISO guidelines. Geostand. Geoanal. Res. 35, 397-429.

Johnson M. C., Rutherford M. J. and Hess P. C. (1991) Chassigny petrogenesis-melt compositions, intensive parameters, and water contents of Martian (?) magmas. Geochim. Cosmochim. Acta 55, 349-366.

Keil K., Fodor R. V., and Bunch, T. E. (1972) Contributions to the mineral chemistry of Hawaiian rocks II. Feldspars and interstitial material in rocks from Haleakala and West Maui volcanoes, Maui, Hawaii. Contrib. to Mineral. Petrol. 37, 253-275.

Langenhorst F. and Greshake A. (1999) A transmission electron microscope study of Chassigny: Evidence for strong shock metamorphism. Meteorit. Planet. Sci. 34, 43-48.

LaTourrette T. Z. and Burnett, D. S. (1992) Experimental determination of U and Th partitioning between clinopyroxene and natural and synthetic basaltic liquid. Earth Planet. Sci. Lett. 110, 227-244.

Lissenberg C. J. and MacLeod C. J. (2016) A reactive porous flow control on mid-ocean ridge magmatic evolution. J. Petrol. 57, 2195-2220.

Lorand J.-P., Barrat J.-A., Chevrier V., Sautter V. and Pont S. (2012) Metal-saturated sulfide assemblages in chassignite NWA 2737; evidence for impact-related sulfur devolatilisation. Meteorit. Planet. Sci. 47, 18301841.

Lorand J.-P., Hewins R.H., Pont S., Zanda B., Humayun M., Nemchin A., Grange M., Kennedy A. and Göpel C. (2015) Nickeliferous pyrite tracks late hydrothermalism in Martian regolith breccia NWA 7533. Meteorit. Planet. Sci., 50, 2099-2120.

Lorand J.-P., Pont S., Chevrier V., Luguet A., Zanda B. and Hewins R. H. (2018) Petrogenesis of martian sulfides in the Chassigny meteorite. Amer. Mineral., special issue "Planetary Sulfides" 103, 872-885.

Mari N., Riches A.J.V., Hallis L.J., Marrocchi Y., Villeneuve J., Gleissner P., Becker H. and Lee, M. (2019) Syneruptive incorporation of martian surface sulphur in the nakhlite lava flows revealed by $\mathrm{S}$ and $\mathrm{Os}$ 
isotopes and highly siderophile elements : implication for mantle sources in Mars. Geochim. Cosmochim. Acta 266, 416-43.

Marsh, B. D. (1996). Solidification fronts and magmatic evolution. Mineral. Mag.60, 5-40.

Mason B., Nelen J. A., Muir P. and Taylor S. R. (1976) The composition of the Chassigny meteorite. Meteoritics 11, 21-27.

McCubbin F. M., Smirnov A., Nekvasil H., Wang J., Hauri E. and Lindsley D. H. (2010) Hydrous magmatism on Mars: A source of water for the surface and subsurface during the Amazonian. Earth Planet. Sci. Lett. 292, 132-138.

McCubbin F. M., Elardo S. M., Shearer C. K., Smirnov A., Hauri E. H. and Draper D. S. (2013) A petrogenetic model for the comagmatic origin of chassignites and nakhlites: Inferences from chlorine-rich minerals, petrology, and geochemistry. Meteorit. Planet. Sci. 48, 819-853.

Mikouchi T., Koizumi E., Monkawa A., Ueda Y. and Miyamoto M. (2003) Mineralogy and petrology of Yamato 000593: Comparison with other Martian nakhlite meteorites. Antarctic Meteorite Research 16, 34-57.

Mikouchi T., Monkawa A., Koizumi E., Chokai J. and Miyamoto M. (2005) MIL03346 Nakhlite and NWA2737" Diderot" Chassignite: Two New Martian Cumulate Rocks from Hot and Cold Deserts. Lunar Planet. Sci. Conf. XXXVI. Lunar Planet. Inst., Houston. \#1944 (abstr.).

Mikouchi T., Miyamoto1, E. Koizumi M., Makishima J. and McKay G. (2006) Relative burial depths of nakhlites: an update. Lunar Planet. Sci. Conf. XXXVII. Lunar Planet. Inst., Houston. \#1865 (abstr.).

Mikouchi T., Takenouchi A. and Zolensky M. E. (2017) Multiple igneous bodies for nakhlites and chassignites as inferred from olivine cooling rates using calcium zoning. Meteorit. Planet. Sci. 52 (Suppl.) \#6177.pdf.

Murri M., Domeneghetti M. C., Fioretti A. M., Nestola F., Vetere F., Perugini D., .. Pisello A., Faccenda M., and Alvaro M. (2019) Cooling history and emplacement of a pyroxenitic lava as proxy for understanding Martian lava flows. Scientific Reports 9, 1-7.

Nagao K., Park J., Choi J., Baek J. M., Haba M. K., Mikouchi T., Zolensky M. E., Herzog G. F., Park C., Lee J. I. and Lee M. J. (2019). Genetic Relationship Between Martian Chassignites and Nakhlites Revealed from Noble Gases. Meteorit. Planet. Sci. 54 (Suppl.) \#6183.pdf.

Nekvasil H., Filiberto J., McCubbin F.M. and Lindsley, D.H. (2007) Alkalic parental magmas for the chassignites? Meteorit. Planet. Sci. 42, 979-992.

Nyquist L. E., Bogard D. D., Shih C.-Y., Greshake A., Stöffler D. and Eugster O. (2001) Ages and geologic histories of martian meteorites. In Chronology and Evolution of Mars, Kallenbach, R., Geiss, J., Hartmann, W.K. (Eds.). Kluwer Academic Publishers, Dordrecht, pp. 105-164.

Oulton J., Humayun M., Fedkin A. and Grossman L. (2016) Chemical evidence for differentiation, evaporation and recondensation from silicate clasts in Gujba. Geochim. Cosmochim. Acta 177, 254-274.

Prinz M., Hlava P. F. and Keil K. (1974) The Chassigny meteorite: a relatively iron-rich cumulate dunite. Meteoritics 9, 393-394.

Rajamani V., Shirey S. B. and Hanson G. N. (1989) Fe-rich Archean tholeiites derived from melt-enriched mantle sources: evidence from the Kolar Schist Belt, South India. J. Geol. 97, 487-501.

Reid A.M. and Bunch T.E. (1975) The nakhlites-II: where, when, and how. Meteoritics 10, 317-324.

Richter F., Chaussidon M., Mendybaev R. and Kite E. (2016) Reassessing the cooling rate and geologic setting of 
Martian meteorites MIL 03346 and NWA 817. Geochim. Cosmochim. Acta 182, 1-23.

Robinson P. (1980) The composition space of terrestrial pyroxenes; internal and external limits. Rev. Mineral. Geochem. 7, 419-494.

Rumble D., Farquhar J., Young E. D. and Christensen C. P. (1997) In situ oxygen isotope analysis with an excimer laser using F2 and BrF5 reagents and $\mathrm{O} 2$ gas as analyte. Geochim. Cosmochim. Acta 61, 4229-4234.

Sack R. O, Carmichael I. S. E., Rivers M. L. and Ghiorso M. S. (1980) Ferric-ferrous equilibria in natural silicate liquids at 1 bar. Contrib. Mineral. Petrol. 75, 369-376.

Sautter V., Barrat J. A., Jambon A., Lorand J. P., Gillet P., Javoy M., Joron J. L. and Lesourd M. (2002) A new Martian meteorite from Morocco: The nakhlite Northwest Africa 817. Earth Planet. Sci. Lett. 195, $223-238$.

Stockstill, K. R., McSween H. Y. Jr. and Bodnar R. J. (2005) Melt inclusions in augite of the Nakhla martian meteorite: Evidence for basaltic parental melt. Meteorit. Planet. Sci. 40, 377-396.

Stolper E. M., McSween H. Y. Jr. and Hays J. F. (1979) A petrogenetic model of the relationships among achondrite meteorites. Geochim. Cosmochim. Acta 43, 589-602.

Treiman A. H. (1986) The parental magma of the Nakhla achondrite: Ultrabasic volcanism on the shergottite parent body. Geochim. Cosmochim. Acta 50, 1061-1070.

Treiman A. H. (2005) The nakhlite meteorites: Augite-rich igneous rocks from Mars. Chem. Erde 65, $203-270$.

Treiman A. H., Dyar M. D., McCanta M., Noble S. K. and Pieters C. M. (2007) Martian dunite NWA 2737: Petrographic constraints on geological history, shock events, and olivine color. J. Geophys. Res.-Planets 112, $1-20$.

Treiman A. H. and Irving A. J. (2008) Petrology of the nakhlite (Martian) meteorite Northwest Africa (NWA) 998. Meteorit. Planet. Sci. 43, 829-854.

Udry A. and Day J.M. (2018) 1.34 billion-year-old magmatism on Mars evaluated from the co-genetic nakhlite and chassignite meteorites. Geochim. Cosmochim. Acta 238, 292-315.

Udry A., McSween H. Y. Jr., Lecumberri-Sanchez P. and Bodnar R. J. (2012) Paired nakhlites MIL 090030, 090032, 090136, and 03346: Insights into the Miller Range parent meteorite, Meteorit. Planet. Sci. 47, 15751589.

Udry A., Balta J. B. and McSween H. Y. Jr. (2014) Exploring fractionation models for Martian magmas. J. Geophys. Res. Planets 119, 1-18.

Valley J. W., Kitchen N. E., Kohn M. J., Niendorf C. R. and Spicuzza M. J. (1995) UWG-2, a garnet standard for oxygen isotope ratios: Strategies for high precision and accuracy with laser heating. Geochim. Cosmochim. Acta 59, 5223-5231.

Vlastélic I., Di Muro A., Bachèlery P., Gurioli L., Auclair D. and Gannoun, A. (2018) Control of source fertility on the eruptive activity of Piton de la Fournaise volcano, La Réunion. Scientific Reports 8, 1-7.

Wadhwa M. and G. Crozaz (1995) Trace and minor elements in minerals of nakhlites and Chassigny: Clues to their petrogenesis. Geochim. Cosmochim. Acta 59, 3629-3645.

Wager L. R., Brown G. M. and W. J. Wadsworth, J. (1960) Types of Igneous Cumulates. J. Petrol. 1, 73-85.

Watson L.L., Hutcheon I.D., Epstein S. and Stolper E.M. (1994) Water on Mars - clues from deuterium/hydrogen and water contents of hydrous phases in SNC meteorites. Science 265, 86-90. 
Welsch, B., Faure, F., Famin, V. and Bachèlery, P. (2013) Dendritic crystallization: a single process for all the textures of olivine in basalts? J. Petrol. 54, 539-574.

Yang S., Humayun M., Righter K., Jefferson G., Fields D. and Irving A. J. (2015) Siderophile and chalcophile element abundances in shergottites: implications for Martian core formation. Meteorit. Planet. Sci. 50, 691714.

Yang S., Humayun, M. Irving A. J., Righter K., Peslier A. H., Zanda B. and Hewins R. H. (2019) A two gigayear history of germanium outgassing from shergottites. A two gigayear history of germanium outgassing from shergottites. Lunar Planet. Sci. Conf. 50 ${ }^{\text {th }}$. Lunar Planet. Inst., Houston \#1908 (abstr.).

Zhang S.H., Zhao Y., Yang Z.Y., He Z.F. and Wu H. (2009) The 1.35 Ga diabase sills from the northern North China Craton: implications for breakup of the Columbia (Nuna) supercontinent. Earth Planet. Sci. Lett. 288, 588-600.

APPENDIX A. SUPPLEMENTARY MATERIAL

Research Data associated with this article are uploaded as a zip file and can be found, in the online version, at https://doi.org/10.1016/j.

Gca......

Table S1. All EMP analyses for NWA 8694, Chassigny and NWA 2737(Excel file).

Table S2. All LA-ICP-MS analyses of NWA 8694 and Chassigny (Excel file).

Fig. S1. Oxygen isotope composition of NWA 8694 with SNC data tabulated by Ali et al. (2016) that were used to calculate the Mars Fractionation Line (MFL) by regression .

Fig. S2. Full size BSE images of the three chassignites (a) NWA 8694 (b) Chassigny (c) NWA 3737. Fig. S3. BSE image. Olivine (off-white), pigeonite (medium grey), and augite (dark grey) in NWA 8694. The common orientation of pyroxene exsolution lamellae NW-SE indicates that pyroxene is poikilitic to olivine.

Fig. S3. BSE image. Olivine (off-white), pigeonite (medium grey), and augite (dark grey) in NWA 8694. The common orientation of pyroxene exsolution lamellae NW-SE indicates that pyroxene is poikilitic to olivine.

Fig. S4.Pyroxene quadrilaterals for NWA 8694 (a) interstitial-poikilitic (b) interstitial mesostasis and (c) melt inclusions.

Fig. S5. The calculated REE pattern of missing phase in NWA 8694 based on excess of bulk P and REE over concentrations calculated from major phasesresembles apatite. The figure shows that an assemblage of $96 \%$ plagioclase and 4\% apatite from NWA 2737 (Beck et al., 2006) matches the REE (La-Gd) of the average trapped liquid in NWA 8694.

Fig. S6. A mixture of 1\% baddeleyite (Zhang et al., 2009) and 99\% NWA 8694 mesostasis give an REE pattern close to that of nakhlite mesostases (Jambon et al., 2016). 
Fig. 1 Back scattered electron (BSE) maps of chassignites (a) NWA 8694 (b) Chassigny (c) NWA 2737. In each image the brightest phase is chromite, followed by olivine, then dark grey pyroxene and black feldspar and glass, but in (c) shocked olivine contains medium grey ribbons or patches.

Fig. 2. NWA 8694 BSE images. (a) Melt inclusion in olivine surrounded by radial fractures: orthopyroxene (Opx); amphibole (Am); K-rich glass (K); and K-poor glass (Na). Note also tiny melt inclusions in the same olivine grain. (b) Olivine and interstitial mesostasis: subophitic pyroxene (medium grey) with feldspar or maskelynite laths (black).

Fig. 3 BSE images of sulfides in NWA 8694. (a) Ni-bearing pyrrhotite in melt inclusion in olivine, associated with apatite and alkali feldspathic glass . (b) Enclosed euhedral Ni-bearing Pyrrhotite crystal associated with fractured apatite inside alkali feldspathic glass. (c) Intercumulus pyrrhotite bleb (light grey) in contact with interstitial glass (dark grey) and olivine (medium grey). (d) Intercumulus pyrite showing fracture networks filled with $\mathrm{Fe}$ oxyhydroxides; this grain shares grain boundaries with olivine (light grey), pyroxene (medium grey) and interstitial glass (dark). (e) Baddeleyite and (f) zirconolite, both occurring in or near contacts between olivine and intercumulus material. PO pyrrhotite, PY pyrite, GL alkali feldspar glass, B baddeleyite, Z zirconolite.

Fig. 4. Olivine compositions. (Top) NWA 8694 is intermediate between the other chassignites and nakhlites in FeO content, with a typical martian $\mathrm{FeO} / \mathrm{MnO}$ ratio. (Bottom) Though $\mathrm{Fe}$ and $\mathrm{Mg}$ are equilibrated Ca varies due to weak zoning. Nakhlite data are from Sautter et al. (2002), Treiman (2005), Udry et al. (2012), and Udry and Day (2018).

Fig. 5. Comparison of compositions of NWA 8694, Chassigny and NWA 2737 pyroxene and olivine with those of nakhlites (Treiman, 2005; Treiman and Irving, 2008; Sautter et al., 2002; Jambon et al., 2016; Treiman et al., 2005; Udry et al., 2012; and Udry and Day, 2018), showing overlap for augite in NWA 998 and Lafayette at En 41-40 Wo $_{38-}$ 39 .

Fig. 6. Pyroxene compositions (afu) showing $\mathrm{Ca}$ and (a) Cr, (b) Na, (c) Ti, and (d) Al. There is a partial overlap for augite in chassignites with augite in NWA 998 and cores in some other nakhlites (Udry and Day (2018) for incompatible minor elements. The other nakhlites show a much wider range of minor element concentrations in augite than the chassignites.

Fig. 7. Composition of chromite in chassignites projected from spinel s.s. onto the chromite-ulvöspinel-magnetite plane. NWA 8694 lacks the Cr-rich chromite found in the other chassignites.

Fig. 8. Compositions of (a) interstitial feldspar for NWA 8694, Chassigny (this work, Floran et al., 1978), NWA 2737, and nakhlites (Bunch and Reid, 1975; Jambon, 2017), and (b) NWA 8694 melt inclusion glass compositions projected onto the An-Ab-Or plane, and compared to those in the two other chassignites (Floran et al., 1978; Mason et al., 1976; Johnson, et al., 1991; Beck et al., 2006; Treiman et al., 2007; He et al., 2013).

Fig. 9. Compositions of interstitial feldspar (FSP), melt inclusion (MI) phases, and bulk interstitial material (the latter from LA-ICP-MS analyses) in NWA 8694 in afu on an eight oxygen basis. Half the plagioclase join $\mathrm{Ab}_{100}-$ $\mathrm{An}_{50}$ to $\mathrm{An}_{50}-\mathrm{Ab}_{100}$ is shown for reference.

Fig. 10. Glass and feldspar compositions plotted in afu. The tieline shows the albite(orthoclase)-An50 join. Some Al-rich glasses plot close to feldspar; other glasses are all Si-rich relative to feldspar, with Al-poor and K-rich points forming a cluster.

Fig. 11. Histograms of Ni content of pyrrhotite (po) and pyrite (py) in NWA 8694 and Chassigny show a shift of Ni content towards lower values in NWA 8694.

Fig. 12. Concentrations of $\mathrm{F}$ and $\mathrm{Cl}$ in biotite in wt\% for NWA 8694 interstitial mesostasis and melt inclusions

Fig. 13. ICP-SFMS analyses for chassignites and mesostasis-rich nahklites (this work, Beck et al., 2005, and Jambon et al., 2016) normalized to CI values (Barrat et al., 2012 ). 
Fig. 14. REE data for NWA 8694 and Chassigny (this work); and NWA 2737 (Beck et al., 2006). (a) Olivine and pyroxene. (b) Mesostasis (interstitial trapped liquid). (c) Mesostasis and bulk compositions of chassignites compared to those of nakhlites (Jambon et al., 2016). The subsamples of NWA 8694 differ in trapped liquid content, with REE concentration pattern of that measured by LA-ICP-MS being close to that of NWA 2737, while the other is almost identical to Chassigny.

Fig. 15. Interstitial material in Chassigny (red diamonds) resembles nakhlite mesostasis, but in NWA 8694 (black diamonds) shows a mixing curve between phosphate-dominated analyses (high L $a_{C I}$ ) and plagioclase-rich analyses (strong positive Eu anomalies). Nakhlite data from Trieman (2005).

Fig. 16. Incompatible element abundances for NWA 8694 and Chassigny mesostases (top two curves) normalized to Martian mantle (Yang et al., 2015) with elements organized according to decreasing incompatibility from left to right. Chassigny mesostasis is very similar to nakhlite mesostases (Jambon et al., 2016), but that in NWA 8694 is depleted in $\mathrm{Zr}, \mathrm{Hf}$, HREE and Sc.

Fig. 17. TAS diagram for daughter liquids from nakhlite parent melt NA01a (Stockstill et al., 2005) with 0\%, 10\% and 20\% added olivine. Crystallization of olivine, augite, and augite plus plagioclase at 1 bar and FMQ-1 produces a match for NWA 8694 mesostasis for the parent with 10\% olivine added.

Fig. 18. AFM diagram for nakhlite parent NA01a (Stockstill et al.2005) with 0\%, 10\% and 20\% added olivine showing calculated olivine and daughter liquid compositions. Crystallization yields olivine matching olivine in NWA 8694, but the calculated liquid is displaced from the natural mesostasis, which retains Mg-bearing pyroxene.

Fig. 19. A cartoon of a zone in a magma chamber from which olivine-undersaturated nakhlite magmas and nakhlite-contaminated chassignite magmas could be extracted to form NWA 998 and NWA 8694.Olivine mauve, pigeonite red, and augite yellow; plagioclase not shown.

Fig. S1. An assemblage of 96\% plagioclase and 4\% apatite from NWA 2737 (Beck et al., 2005) matches the REE (La-Gd) of the average trapped liquid in NWA 8694.

Fig. S2. A mixture of 1\% baddeleyite (Zhang et al., 2009) and NWA 8694 mesostasis give a REE pattern close to that of nakhlite mosostases (Jambon et al., 2016).

Fig. S3. TAS diagram for selected parent liquids (Table 6). 
Table 1 Chassignite modal abundances.

Table 2a. Selected analyses of olivine, chromite, biotite and amphibole.

Table 2b. Selected analyses of pyroxene.

Table 3. Selected analyses of feldspars.

Table 4. Selected analyses of glass, and average apatite in NWA 8694.

Table 5 Mean composition of NWA 8694 sulfides.

Table 6. Whole Rock analyses of three chassignites.

Table 7. LA-ICP-MS average analyses for NWA 8694 and Chassigny.

Table 7. Table 7. LA-ICP-MS average analyses (continued).

Table 8. Compositions of parent liquids used in PETROLOG calculations.

Table S1. All LA-ICP-MS analyses for NWA 8694 and Chassigny. 


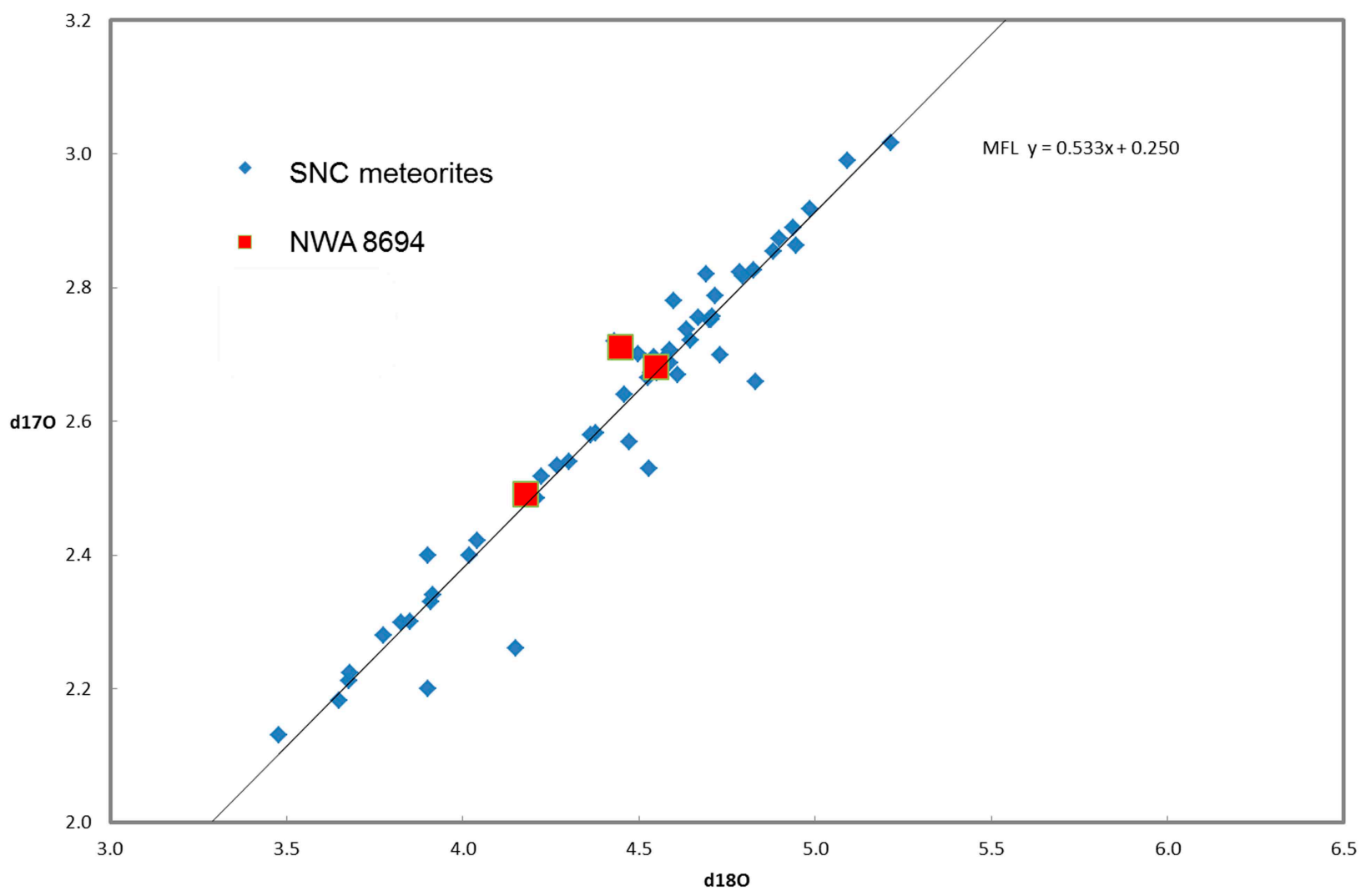




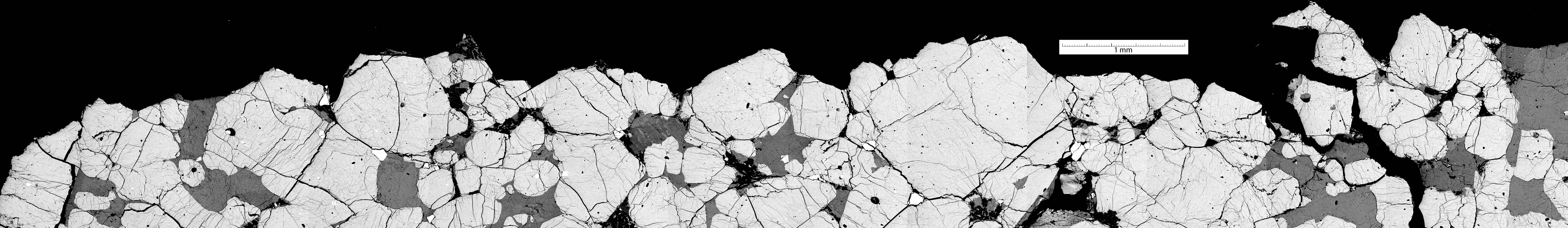

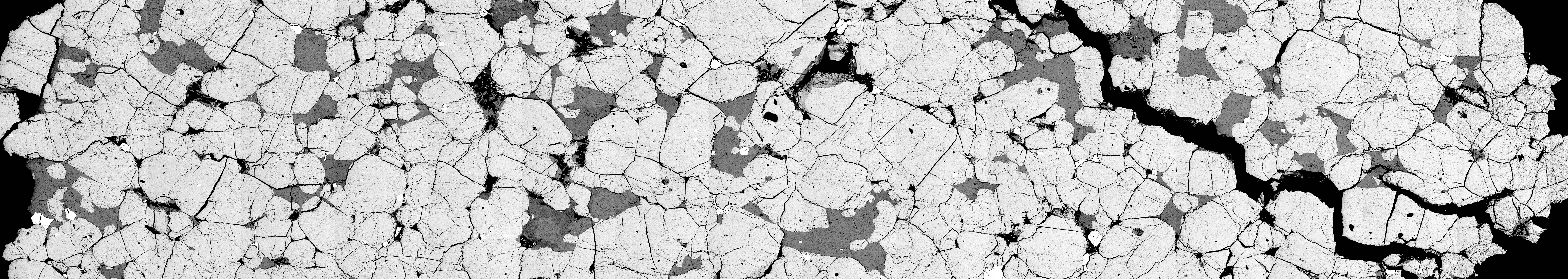

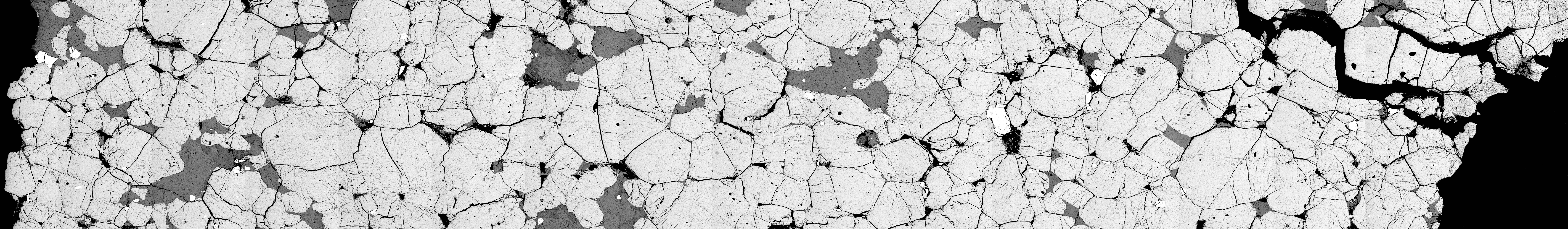

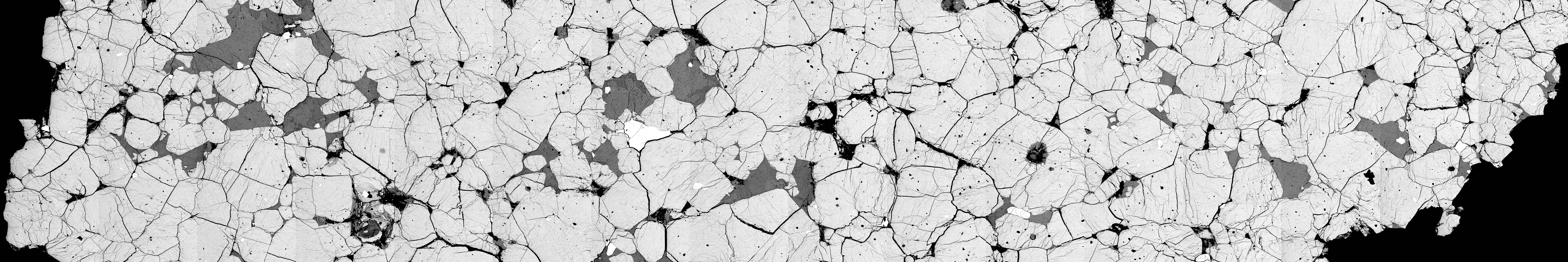
- $x^{-1}+3+2+1$

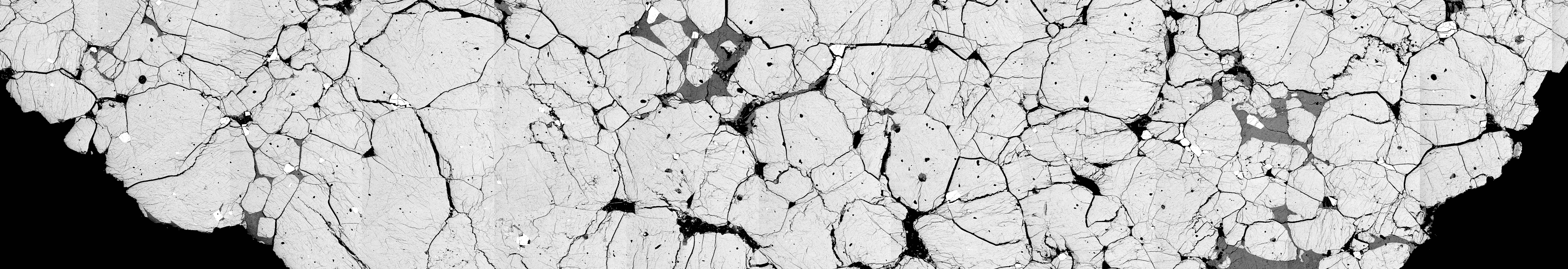




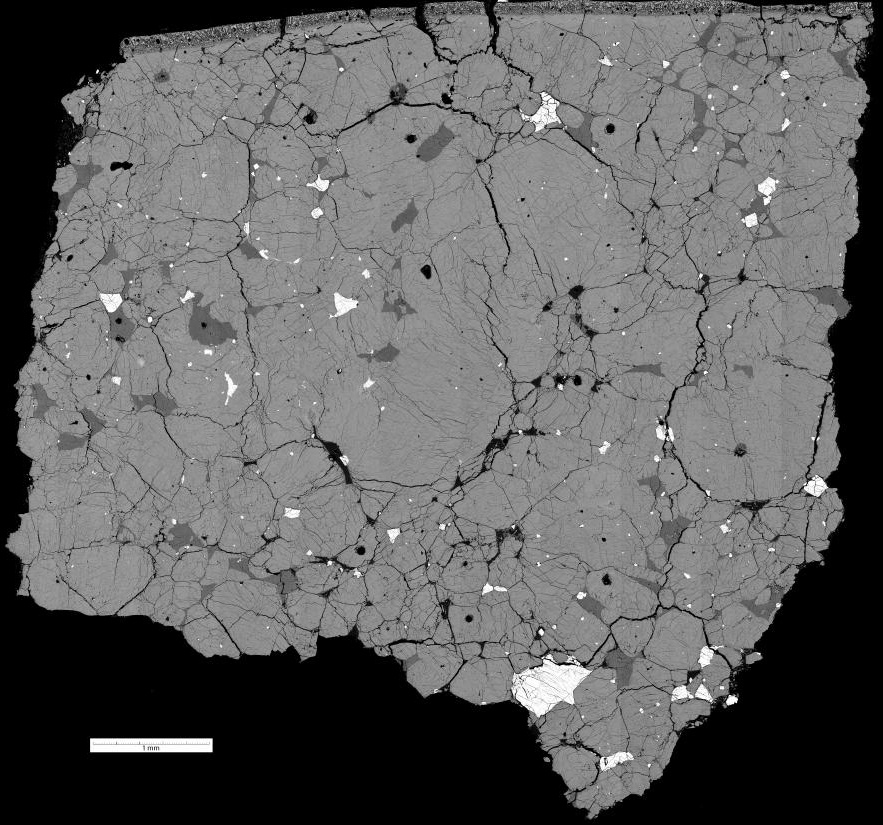




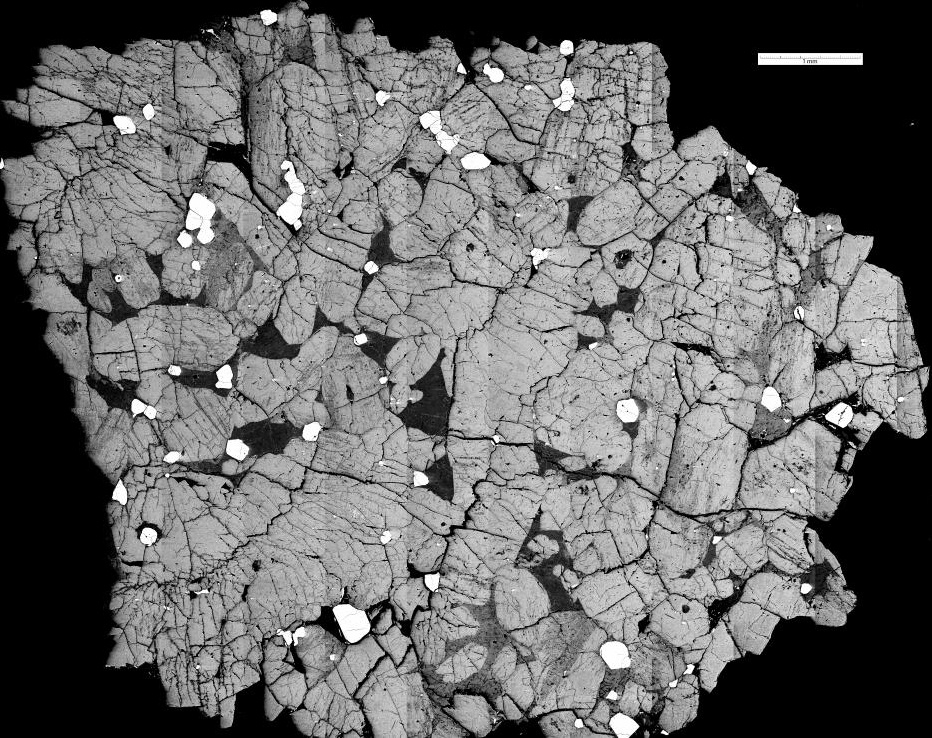




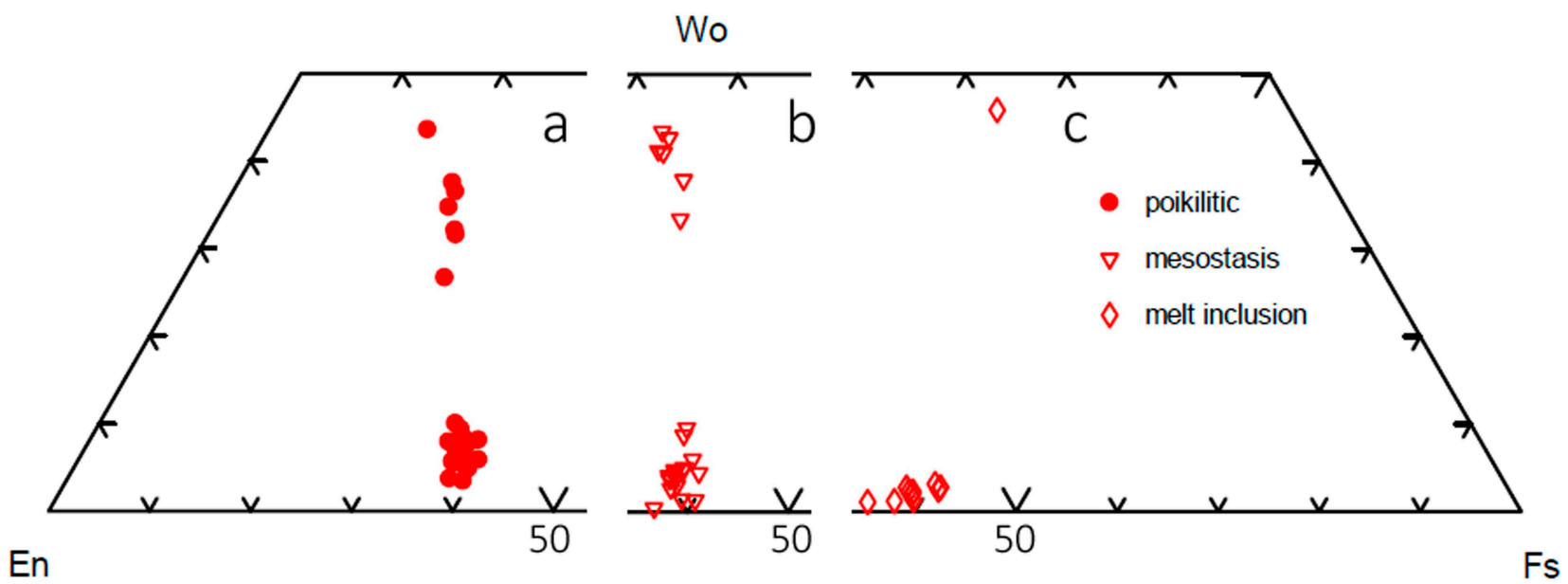




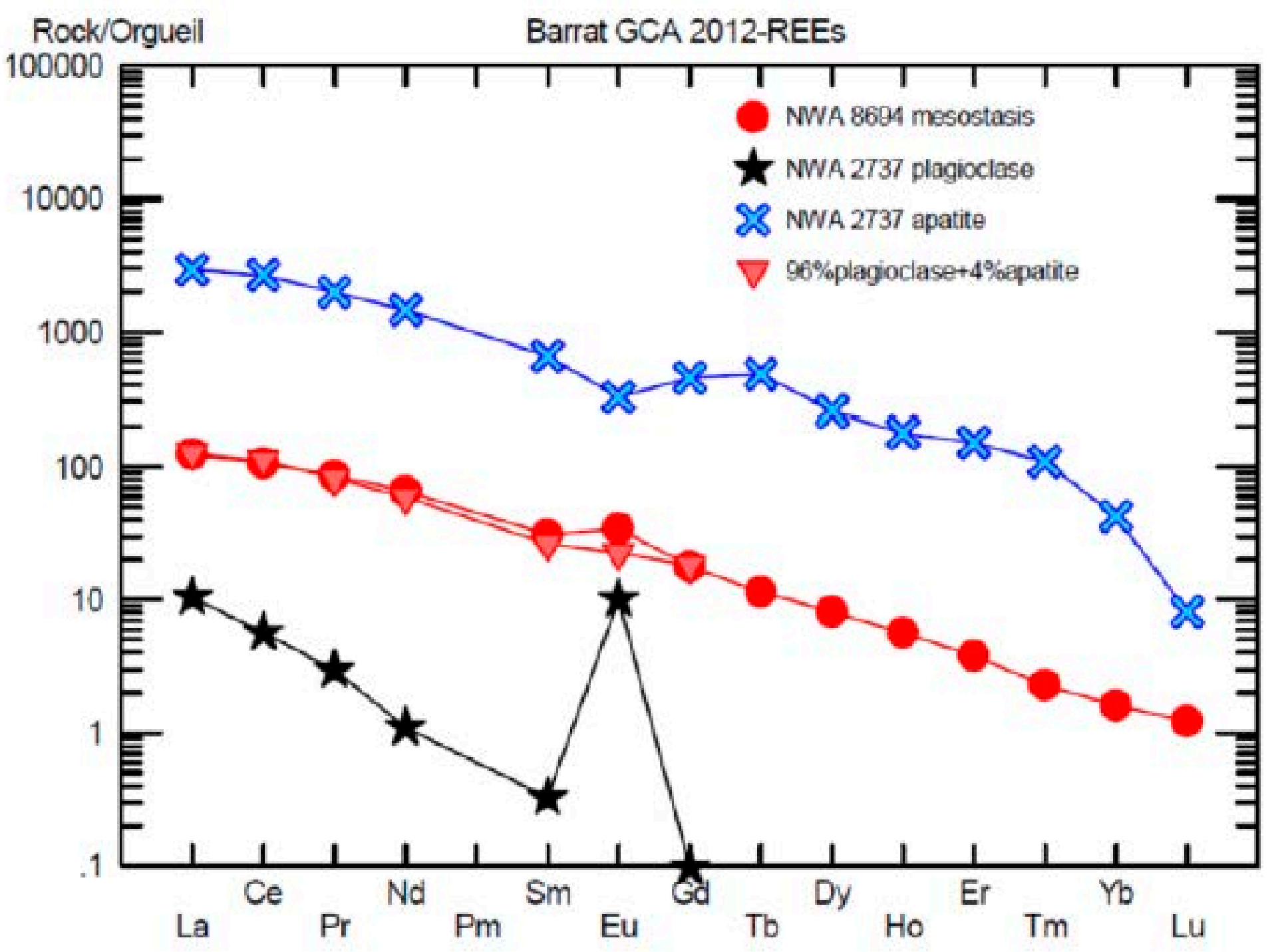




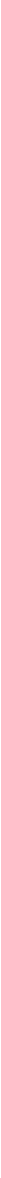


Supplementary Table Olivine Analyses.

\begin{tabular}{|c|c|c|c|c|c|c|c|c|c|c|c|}
\hline Point & Session & Fo & $\mathrm{Fa}$ & $\mathrm{SiO}_{2}$ & $\mathrm{Al}_{2} \mathrm{O}_{3}$ & $\mathrm{TiO}_{2}$ & $\mathrm{Cr}_{2} \mathrm{O}_{3}$ & $\mathrm{FeO}$ & MnO & MgO & $\mathrm{CaO}$ \\
\hline \multicolumn{12}{|l|}{ NWA 8694} \\
\hline 1 & 121114 & 53,72 & 46,28 & 35,75 & 0,02 & 0,09 & 0,04 & 39,18 & 0,82 & 25,51 & 0,23 \\
\hline 6 & 121114 & 53,61 & 46,39 & 35,87 & 0,02 & $\mathrm{bd}$ & 0,02 & 39,06 & 0,79 & 25,32 & 0,16 \\
\hline 7 & 121114 & 53,17 & 46,83 & 35,31 & 0,04 & $\mathrm{bd}$ & 0,03 & 39,14 & 0,78 & 24,93 & 0,29 \\
\hline 12 & 121114 & 52,48 & 47,52 & 35,53 & 0,03 & 0,04 & 0,04 & 39,45 & 0,76 & 24,44 & 0,18 \\
\hline 20 & 121114 & 53,92 & 46,08 & 35,72 & 0,05 & 0,02 & 0,20 & 38,21 & 0,77 & 25,08 & 0,13 \\
\hline 21 & 121114 & 53,24 & 46,76 & 35,89 & $\mathrm{bd}$ & 0,05 & $b d$ & 39,05 & 0,79 & 24,95 & 0,19 \\
\hline 22 & 121114 & 53,44 & 46,56 & 36,11 & 0,03 & $b d$ & 0,05 & 38,54 & 0,81 & 24,81 & 0,17 \\
\hline 23 & 121114 & 53,19 & 46,81 & 36,06 & 0,03 & 0,04 & $\mathrm{bd}$ & 39,44 & 0,82 & 25,14 & 0,22 \\
\hline 34 & 121114 & 52,89 & 47,11 & 36,10 & 0,05 & 0,02 & $\mathrm{bd}$ & 39,07 & 0,78 & 24,60 & 0,13 \\
\hline 52 & 121114 & 53,01 & 46,99 & 35,74 & 0,07 & 0,04 & 0,07 & 38,81 & 0,75 & 24,56 & 0,19 \\
\hline 85 & 121114 & 53,32 & 46,68 & 36,38 & 0,01 & 0,03 & 0,04 & 39,26 & 0,83 & 25,15 & 0,18 \\
\hline 87 & 121114 & 53,32 & 46,68 & 36,26 & 0,02 & 0,01 & 0,03 & 39,11 & 0,80 & 25,06 & 0,23 \\
\hline 88 & 121114 & 53,29 & 46,71 & 35,75 & $\mathrm{bd}$ & 0,04 & $b d$ & 39,02 & 0,80 & 24,98 & 0,18 \\
\hline 91 & 121114 & 52,98 & 47,02 & 36,11 & 0,03 & 0,06 & 0,04 & 39,26 & 0,74 & 24,82 & 0,17 \\
\hline 94 & 121114 & 53,42 & 46,58 & 35,74 & 0,01 & 0,06 & 0,06 & 38,81 & 0,76 & 24,97 & 0,28 \\
\hline 95 & 121114 & 53,11 & 46,89 & 36,35 & 0,06 & 0,03 & $b d$ & 39,06 & 0,78 & 24,82 & 0,23 \\
\hline $97 / 62$ & 121114 & 53,19 & 46,81 & 35,74 & 0,02 & 0,04 & 0,04 & 38,99 & 0,78 & 24,85 & 0,12 \\
\hline $97 / 63$ & 121114 & 53,09 & 46,91 & 35,19 & 0,02 & 0,05 & $\mathrm{bd}$ & 38,65 & 0,78 & 24,54 & 0,13 \\
\hline $97 / 64$ & 121114 & 53,15 & 46,85 & 35,49 & 0,02 & 0,04 & 0,03 & 38,61 & 0,80 & 24,57 & 0,12 \\
\hline $97 / 65$ & 121114 & 53,31 & 46,69 & 35,40 & 0,04 & 0,06 & 0,04 & 39,04 & 0,76 & 25,00 & 0,14 \\
\hline $97 / 66$ & 121114 & 53,00 & 47,00 & 35,43 & 0,04 & $\mathrm{bd}$ & 0,06 & 38,83 & 0,76 & 24,56 & 0,12 \\
\hline 94 & 021214 & 53,63 & 46,37 & 36,03 & 0,05 & bd & 0,08 & 38,71 & 0,86 & 25,11 & 0,15 \\
\hline 95 & 021214 & 53,55 & 46,45 & 35,69 & 0,06 & 0,06 & 0,06 & 38,45 & 0,81 & 24,87 & 0,16 \\
\hline 96 & 021214 & 53,32 & 46,68 & 35,30 & $\mathrm{bd}$ & 0,04 & $b d$ & 38,93 & 0,86 & 24,95 & 0,20 \\
\hline 97 & 021214 & 54,22 & 45,78 & 35,64 & 0,02 & 0,01 & 0,02 & 38,12 & 0,88 & 25,32 & 0,19 \\
\hline 98 & 021214 & 53,26 & 46,74 & 36,06 & 0,01 & $\mathrm{bd}$ & 0,03 & 39,23 & 0,91 & 25,07 & 0,21 \\
\hline 99 & 021214 & 53,35 & 46,65 & 35,62 & $b d$ & 0,09 & $b d$ & 39,18 & 0,75 & 25,14 & 0,12 \\
\hline 100 & 021214 & 53,30 & 46,70 & 35,93 & 0,04 & $b d$ & 0,03 & 38,48 & 0,80 & 24,64 & 0,18 \\
\hline 101 & 021214 & 53,04 & 46,96 & 35,46 & 0,01 & 0,06 & 0,01 & 39,15 & 0,77 & 24,81 & 0,17 \\
\hline $102 / 1$ & 021214 & 53,59 & 46,41 & 35,74 & 0,03 & 0,01 & 0,05 & 38,79 & 0,82 & 25,13 & 0,15 \\
\hline $102 / 2$ & 021214 & 53,65 & 46,35 & 35,35 & 0,02 & $\mathrm{bd}$ & $b d$ & 38,57 & 0,77 & 25,05 & 0,16 \\
\hline $102 / 3$ & 021214 & 52,84 & 47,16 & 35,02 & 0,10 & 0,06 & 0,01 & 39,17 & 0,80 & 24,62 & 0,18 \\
\hline $102 / 4$ & 021214 & 52,94 & 47,06 & 35,24 & 0,08 & $b d$ & $b d$ & 38,50 & 0,88 & 24,30 & 0,20 \\
\hline $102 / 6$ & 021214 & 53,10 & 46,90 & 35,98 & 0,03 & 0,01 & bd & 38,93 & 0,87 & 24,73 & 0,19 \\
\hline $102 / 7$ & 021214 & 53,22 & 46,78 & 35,47 & 0,02 & 0,04 & 0,04 & 39,21 & 0,78 & 25,03 & 0,17 \\
\hline $102 / 8$ & 021214 & 53,53 & 46,47 & 35,12 & bd & 0,06 & 0,05 & 38,63 & 0,79 & 24,97 & 0,16 \\
\hline $102 / 9$ & 021214 & 53,29 & 46,71 & 35,26 & 0,04 & $\mathrm{bd}$ & 0,03 & 38,99 & 0,78 & 24,95 & 0,21 \\
\hline $102 / 10$ & 021214 & 52,97 & 47,03 & 34,65 & 0,10 & 0,02 & 0,03 & 39,03 & 0,82 & 24,66 & 0,21 \\
\hline $102 / 12$ & 021214 & 52,54 & 47,46 & 35,48 & 0,06 & 0,05 & $\mathrm{bd}$ & 39,68 & 0,76 & 24,64 & 0,16 \\
\hline $102 / 13$ & 021214 & 53,25 & 46,75 & 35,67 & 0,02 & 0,04 & 0,01 & 38,93 & 0,73 & 24,87 & 0,16 \\
\hline $102 / 14$ & 021214 & 53,42 & 46,58 & 35,39 & 0,01 & 0,06 & 0,01 & 38,93 & 0,88 & 25,04 & 0,16 \\
\hline $102 / 15$ & 021214 & 53,35 & 46,65 & 35,73 & bd & $\mathrm{bd}$ & $\mathrm{bd}$ & 39,37 & 0,81 & 25,26 & 0,16 \\
\hline $102 / 16$ & 021214 & 53,46 & 46,54 & 35,53 & 0,02 & 0,02 & 0,01 & 38,68 & 0,78 & 24,92 & 0,13 \\
\hline $102 / 17$ & 021214 & 53,15 & 46,85 & 35,90 & 0,05 & 0,07 & 0,01 & 38,90 & 0,80 & 24,75 & 0,12 \\
\hline $102 / 18$ & 021214 & 53,58 & 46,42 & 35,68 & $\mathrm{bd}$ & $\mathrm{bd}$ & $b d$ & 38,86 & 0,88 & 25,16 & 0,04 \\
\hline $102 / 19$ & 021214 & 53,95 & 46,05 & 35,76 & $b d$ & 0,04 & 0,03 & 38,11 & 0,93 & 25,05 & 0,14 \\
\hline $102 / 20$ & 021214 & 53,11 & 46,89 & 35,24 & bd & 0,02 & $\mathrm{bd}$ & 39,02 & 0,79 & 24,79 & 0,21 \\
\hline $102 / 21$ & 021214 & 52,74 & 47,26 & 35,27 & 0,03 & 0,09 & bd & 38,64 & 0,78 & 24,19 & 0,25 \\
\hline $102 / 22$ & 021214 & 53,40 & 46,60 & 35,19 & bd & 0,01 & bd & 38,96 & 0,92 & 25,05 & 0,18 \\
\hline $102 / 23$ & 021214 & 53,55 & 46,45 & 35,41 & $\mathrm{bd}$ & $\mathrm{bd}$ & $\mathrm{bd}$ & 38,66 & 0,85 & 25,00 & 0,16 \\
\hline $102 / 24$ & 021214 & 53,29 & 46,71 & 35,27 & 0,06 & 0,03 & 0,01 & 38,40 & 0,83 & 24,58 & 0,19 \\
\hline $102 / 25$ & 021214 & 53,22 & 46,78 & 35,48 & 0,04 & $\mathrm{bd}$ & $b d$ & 38,84 & 0,75 & 24,79 & 0,16 \\
\hline $102 / 26$ & 021214 & 53,16 & 46,84 & 35,17 & 0,02 & 0,06 & 0,01 & 38,70 & 0,83 & 24,64 & 0,24 \\
\hline $102 / 27$ & 021214 & 52,81 & 47,19 & 35,95 & $\mathrm{bd}$ & 0,03 & $\mathrm{bd}$ & 39,24 & 0,77 & 24,63 & 0,18 \\
\hline $102 / 28$ & 021214 & 53,34 & 46,66 & 35,42 & 0,02 & 0,04 & $b d$ & 38,94 & 0,75 & 24,97 & 0,14 \\
\hline $102 / 29$ & 021214 & 53,86 & 46,14 & 35,37 & 0,03 & $b d$ & 0,01 & 38,23 & 0,78 & 25,03 & 0,14 \\
\hline
\end{tabular}




\begin{tabular}{|c|c|c|c|c|c|c|c|c|c|c|c|}
\hline $102 / 30$ & 021214 & 53,29 & 46,71 & 35,17 & bd & 0,04 & 0,02 & 38,57 & 0,84 & 24,69 & 0,21 \\
\hline $102 / 31$ & 021214 & 53,45 & 46,55 & 35,47 & 0,04 & 0,01 & 0,01 & 38,72 & 0,74 & 24,94 & 0,18 \\
\hline $102 / 32$ & 021214 & 53,65 & 46,35 & 35,46 & bd & 0,09 & bd & 38,64 & 0,91 & 25,09 & 0,13 \\
\hline $102 / 33$ & 021214 & 53,59 & 46,41 & 35,70 & 0,04 & 0,04 & 0,02 & 39,32 & 0,82 & 25,47 & 0,14 \\
\hline $102 / 36$ & 021214 & 52,85 & 47,15 & 35,94 & 0,07 & 0,05 & 0,07 & 39,19 & 0,81 & 24,65 & 0,15 \\
\hline $102 / 37$ & 021214 & 3,84 & 46,16 & 35,68 & 0,02 & 0,05 & bd & 38,48 & 0,84 & 25,18 & 0,14 \\
\hline $102 / 38$ & 021214 & 53,85 & 46,15 & 35,70 & 0,01 & bd & 0,02 & 38,92 & 0,82 & 25,48 & 0,11 \\
\hline $102 / 39$ & 021214 & 52,97 & 47,03 & 34,78 & 0,06 & 0,02 & bd & 38,48 & 0,80 & 24,31 & 0,13 \\
\hline $102 / 40$ & 021214 & 53,17 & 46,83 & 35,59 & 0,01 & 0,03 & bd & 38,50 & 0,80 & 24,52 & 0,12 \\
\hline $102 / 41$ & 021214 & 53,29 & 46,71 & 35,65 & 0,05 & 0,04 & 0,01 & 38,82 & 0,79 & 24,84 & 0,14 \\
\hline $102 / 42$ & 021214 & 53,43 & 46,57 & 35,74 & 0,06 & 0,03 & 0,01 & 38,67 & 0,84 & 24,89 & 0,15 \\
\hline $102 / 43$ & 021214 & 53,82 & 46,18 & 35,27 & bd & bd & bd & 38,02 & 0,88 & 24,86 & 0,13 \\
\hline $102 / 44$ & 021214 & 53,75 & 46,25 & 35,53 & bd & 0,03 & bd & 38,64 & 0,85 & 25,19 & 0,13 \\
\hline $102 / 45$ & 021214 & 53,53 & 46,47 & 35,53 & 0,02 & 0,03 & bd & 38,52 & 0,72 & 24,89 & 0,11 \\
\hline $102 / 46$ & 021214 & 53,31 & 46,69 & 36,00 & 0,02 & 0,05 & bd & 39,06 & 0,89 & 25,03 & 0,11 \\
\hline $102 / 47$ & 021214 & 53,25 & 46,75 & 35,79 & 0,05 & 0,09 & 0,05 & 39,01 & 0,84 & 24,92 & 0,12 \\
\hline $102 / 48$ & 021214 & 52,88 & 47,12 & 35,73 & 0,09 & 0,06 & 0,01 & 39,15 & 0,86 & 24,65 & 0,14 \\
\hline $102 / 50$ & 021214 & 53,04 & 46,96 & 36,00 & 0,17 & 0,02 & bd & 38,86 & 0,87 & 24,62 & 0,17 \\
\hline $102 / 51$ & 021214 & 53,70 & 46,30 & 35,68 & bd & 0,04 & bd & 38,26 & 0,77 & 24,89 & 0,10 \\
\hline $102 / 52$ & 021214 & 53,52 & 46,48 & 35,49 & 0,01 & bd & $\mathrm{bd}$ & 38,68 & 0,78 & 24,99 & 0,11 \\
\hline $102 / 53$ & 021214 & 53,80 & 46,20 & 35,44 & 0,02 & 0,03 & 0,04 & 38,20 & 0,82 & 24,96 & 0,12 \\
\hline $102 / 54$ & 021214 & 53,71 & 46,29 & 35,64 & 0,03 & bd & bd & 38,68 & 0,85 & 25,17 & 0,09 \\
\hline $102 / 55$ & 021214 & 53,78 & 46,22 & 35,79 & 0,01 & 0,04 & 0,07 & 38,46 & 0,89 & 25,10 & 0,12 \\
\hline $102 / 56$ & 021214 & 53,66 & 46,34 & 35,55 & 0,06 & bd & bd & 38,78 & 0,89 & 25,19 & 0,08 \\
\hline $102 / 57$ & 021214 & 53,91 & 46,09 & 36,13 & 0,01 & 0,01 & 0,04 & 38,36 & 0,86 & 25,17 & 0,09 \\
\hline $102 / 58$ & 021214 & 53,57 & 46,43 & 35,47 & 0,06 & bd & 0,04 & 38,83 & 0,82 & 25,13 & 0,11 \\
\hline $102 / 59$ & 021214 & 54,25 & 45,75 & 35,31 & 0,02 & 0,06 & bd & 38,71 & 0,80 & 25,75 & 0,09 \\
\hline $102 / 60$ & 021214 & 54,83 & 45,17 & 35,40 & bd & 0,03 & 0,06 & 37,11 & 0,83 & 25,27 & 0,08 \\
\hline 1 & 121114 & 53,72 & 46,28 & 35,75 & 0,02 & 0,09 & 0,04 & 39,18 & 0,82 & 25,51 & 0,23 \\
\hline 6 & 121114 & 53,61 & 46,39 & 35,87 & 0,02 & bd & 0,02 & 39,06 & 0,79 & 25,32 & 0,16 \\
\hline 7 & 121114 & 53,17 & 46,83 & 35,31 & 0,04 & bd & 0,03 & 39,14 & 0,78 & 24,93 & 0,29 \\
\hline 12 & 121114 & 52,48 & 47,52 & 35,53 & 0,03 & 0,04 & 0,04 & 39,45 & 0,76 & 24,44 & 0,18 \\
\hline 20 & 121114 & 53,92 & 46,08 & 35,72 & 0,05 & 0,02 & 0,20 & 38,21 & 0,77 & 25,08 & 0,13 \\
\hline 21 & 121114 & 3,24 & 46,76 & 35,89 & bd & 0,05 & bd & 39,05 & 0,79 & 24,95 & 0,19 \\
\hline 22 & 121114 & 3,44 & 46,56 & 36,11 & 0,03 & bd & 0,05 & 38,54 & 0,81 & 24,81 & 0,17 \\
\hline 23 & 121114 & 53,19 & 46,81 & 36,06 & 0,03 & 0,04 & bd & 39,44 & 0,82 & 25,14 & 0,22 \\
\hline 34 & 121114 & 52,89 & 47,11 & 36,10 & 0,05 & 0,02 & $\mathrm{bd}$ & 39,07 & 0,78 & 24,60 & 0,13 \\
\hline 52 & 121114 & 53,01 & 46,99 & 35,74 & 0,07 & 0,04 & 0,07 & 38,81 & 0,75 & 24,56 & 0,19 \\
\hline 85 & 121114 & 53,32 & 46,68 & 36,38 & 0,01 & 0,03 & 0,04 & 39,26 & 0,83 & 25,15 & 0,18 \\
\hline 87 & 121114 & 53,32 & 46,68 & 36,26 & 0,02 & 0,01 & 0,03 & 39,11 & 0,80 & 25,06 & 0,23 \\
\hline 88 & 121114 & 53,29 & 46,71 & 35,75 & bd & 0,04 & bd & 39,02 & 0,80 & 24,98 & 0,18 \\
\hline 91 & 121114 & 52,98 & 47,02 & 36,11 & 0,03 & 0,06 & 0,04 & 39,26 & 0,74 & 24,82 & 0,17 \\
\hline 94 & 121114 & 53,42 & 46,58 & 35,74 & 0,01 & 0,06 & 0,06 & 38,81 & 0,76 & 24,97 & 0,28 \\
\hline 95 & 121114 & 3,11 & 46,89 & 36,35 & 0,06 & 0,03 & bd & 39,06 & 0,78 & 24,82 & 0,23 \\
\hline $97 / 62$ & 121114 & 53,19 & 46,81 & 35,74 & 0,02 & 0,04 & 0,04 & 38,99 & 0,78 & 24,85 & 0,12 \\
\hline 97/63. & 121114 & 53,09 & 46,91 & 35,19 & 0,02 & 0,05 & bd & 38,65 & 0,78 & 24,54 & 0,13 \\
\hline $97 / 64$ & 121114 & 53,15 & 46,85 & 35,49 & 0,02 & 0,04 & 0,03 & 38,61 & 0,80 & 24,57 & 0,12 \\
\hline $97 / 65$ & 121114 & 3,31 & 46,69 & 35,40 & 0,04 & 0,06 & 0,04 & 39,04 & 0,76 & 25,00 & 0,14 \\
\hline $97 / 66$ & 121114 & 53,00 & 47,00 & 35,43 & 0,04 & $\mathrm{bd}$ & 0,06 & 38,83 & 0,76 & 24,56 & 0,12 \\
\hline 26-LA-ICP-MS & & 67,86 & 32,14 & 35,30 & 0,02 & 0,02 & 0,02 & 38,02 & 0,84 & 25,50 & 0,24 \\
\hline 27-LA-ICP-MS & & 54,45 & 45,55 & 35,07 & 0,02 & 0,02 & 0,02 & 38,44 & 0,82 & 25,35 & 0,21 \\
\hline 28-LA-ICP-MS & & 54,03 & 45,97 & 35,07 & 0,05 & 0,04 & 0,19 & 38,38 & 0,84 & 25,36 & 0,21 \\
\hline 29-LA-ICP-MS & & 54,08 & 45,92 & 35,41 & 0,02 & 0,03 & 0,02 & 38,24 & 0,83 & 25,22 & 0,20 \\
\hline 30-LA-ICP-MS & & 54,03 & 45,97 & 35,18 & 0,02 & 0,02 & 0,02 & 38,24 & 0,84 & 25,42 & 0,24 \\
\hline \multicolumn{12}{|l|}{ Chassigny } \\
\hline 10 & 1211 & 68,12 & 32,28 & 37,51 & 0,03 & 0,03 & 0,02 & 28,69 & 0,55 & 33,77 & 0,15 \\
\hline 11 & 071211 & 68,12 & 31,88 & 37,41 & 0,03 & 0,02 & 0,04 & 28,50 & 0,55 & 34,16 & 0,16 \\
\hline 12 & 071211 & 67,69 & 31,88 & 37,84 & 0,03 & 0,02 & 0,12 & 28,38 & 0,48 & 34,03 & 0,12 \\
\hline 5 & 200913 & 67,86 & 32,14 & 38,11 & 0,02 & $b d$ & 0,02 & 28,61 & 0,55 & 33,89 & 0,15 \\
\hline
\end{tabular}




\begin{tabular}{|c|c|c|c|c|c|c|c|c|c|c|c|}
\hline 8 & 200913 & 67,94 & 32,06 & 37,90 & 0,01 & 0,03 & $\mathrm{bd}$ & 28,27 & 0,54 & 33,62 & 0,16 \\
\hline 11 & 200913 & 67,42 & 32,58 & 37,40 & 0,02 & 0,02 & 0,03 & 28,89 & 0,59 & 33,54 & 0,11 \\
\hline 13 & 200913 & 67,32 & 32,68 & 37,06 & 0,03 & bd & 0,06 & 28,97 & 0,54 & 33,48 & 0,13 \\
\hline 102 & 111213 & 67,42 & 32,58 & 35,67 & bd & $\mathrm{bd}$ & 0,02 & 28,84 & 0,63 & 33,48 &, 13 \\
\hline 22 & 111213 & 67,62 & 32,38 & 36,45 & 0,01 & 0,05 & 0,07 & 28,39 & 0,55 & 33,26 & ,15 \\
\hline 24 & 111213 & 68,54 & 31,46 & 35,73 & 0,03 & 0,09 & 0,09 & 27,79 & 0,44 & 33,95 & 0,14 \\
\hline 26 & 111213 & 67,81 & 32,19 & 35,28 & 0,07 & 0,07 & 0,05 & 28,38 & 0,57 & 33,54 & ,16 \\
\hline 4 & 111213 & 67,86 & 32,14 & 36,87 & 0,02 & 0,01 & bd & 28,66 & 0,68 & 33,96 & 0,09 \\
\hline 18 & 220318 & 68,31 & 1,69 & 37,65 & 0,01 & 0,02 & 0,02 & 28,24 & 0,58 & 34,16 & , 14 \\
\hline 19 & 220318 & 68,10 & 1,90 & 36,92 & 0,00 & 0,04 & 0,03 & 8,39 & 0,54 & 4,00 & ,11 \\
\hline 20 & 220318 & 67,96 & 32,04 & 37,37 & 0,03 & 0,01 & 0,05 & 28,56 & 0,51 & 33,98 &, 13 \\
\hline 21 & 220318 & 68,01 & 31,99 & 37,96 & 0,05 & 0,06 & 0,02 & 28,62 & 0,53 & 34,14 & 0,17 \\
\hline 22 & 220318 & 68,18 & 31,82 & 37,37 & 0,04 & 0,04 & 0,03 & 27,91 & 0,53 & 33,54 & 0,14 \\
\hline 23 & 220318 & 67,96 & 32,04 & 37,55 & 0,03 & bd & 0,02 & 28,56 & 0,54 & 33,98 & 0,21 \\
\hline 24 & 220318 & 67,89 & 32,11 & 37,94 & 0,02 & bd & 0,03 & 28,67 & 0,56 & 34,00 & 0,27 \\
\hline 25 & 220318 & 68,38 & 31,62 & 37,90 & 0,03 & 0,02 & 0,05 & 28,30 & 0,61 & 34,33 & 0,23 \\
\hline 26 & 220318 & 68,40 & 31,60 & 38,14 & 0,03 & 0,03 & 0,04 & 28,04 & 0,53 & 34,05 & ,13 \\
\hline 27 & 220318 & 68,17 & 31,83 & 38,27 & 0,01 & 0,03 & 0,03 & 28,34 & 0,49 & 34,05 & 0,13 \\
\hline 26-LA-ICP-MS & & 67,69 & 32,31 & 36,47 & 0,02 & 0,02 & 0,02 & 28,82 & 0,57 & 33,88 & 0,15 \\
\hline 27-LA-ICP-MS & & 67,24 & 32,76 & 36,21 & 0,11 & 0,03 & 0,31 & 29,07 & 0,57 & 33,48 &, 17 \\
\hline 28-LA-ICP-MS & & 68,07 & 31,93 & 36,46 & 0,02 & 0,02 & 0,02 & 28,53 & 0,57 & 34,12 & 0,19 \\
\hline 29-LA-ICP-MS & & 68,03 & 31,97 & 36,28 & 0,02 & 0,02 & 0,03 & 8,64 & 0,56 & 34,19 & 0,22 \\
\hline 30-LA-ICP-MS & & 67,64 & 32,36 & 36,46 & 0,02 & 0,02 & 0,03 & 28,84 & 0,57 & 33,82 & 0,21 \\
\hline 31-LA-ICP-MS & & 67,77 & 32,23 & 36,43 & 0,02 & 0,02 & 0,02 & 8,77 & 0,57 & 33,95 &, 18 \\
\hline 32-LA-ICP-MS & & 67,61 & 32,39 & 36,44 & 0,02 & 0,02 & 0,03 & 8,87 & 0,57 & 33,81 & 0,19 \\
\hline \multicolumn{12}{|l|}{ NWA 2737} \\
\hline 50/1. & 181217 & 7,86 & 22,14 & 39,10 & 0,01 & 0,04 & 0,03 & & 0,37 & 40,97 & 0,11 \\
\hline $54 / 1$ & 1812 & 78,13 & 21,87 & 39,97 & 0,02 & bd & 0,04 & ,33 & 0,41 & 71 & 0,09 \\
\hline $56 / 1$ & 181217 & 78,04 & 21,96 & 39,86 & $\mathrm{bd}$ & $\mathrm{bd}$ & 0,04 & 20,45 & 0,3 & 40,81 & 0,14 \\
\hline $59 / 1$ & 181217 & 78,29 & 21,71 & 40,30 & bd & 0,04 & 0,07 & 20,17 & 0,44 & 40,82 & 0,13 \\
\hline 61/1. & 181217 & 78,30 & 21,70 & 39,19 & 0,20 & bd & bd & 19,89 & 0,40 & 40,25 & 0,18 \\
\hline 64/1. & 181217 & 78,04 & 21,96 & 39,13 & 0,04 & 0,04 & 0,06 & 20,36 & 0,42 & 40,61 & 0,11 \\
\hline 66/1. & 181217 & 78,01 & 21,99 & 39,43 & 0,07 & 0,02 & 0,05 & 20,47 & 0,4 & 40,74 & 0,25 \\
\hline 68/1. & 181217 & 78,45 & 21,55 & 39,24 & 0,02 & bd & 0,03 & 20,13 & 0,4 & 41,10 & 0,12 \\
\hline 74/1. & 181217 & 78,12 & 21,88 & 39,76 & bd & bd & 0,02 & 20,34 & & 40,77 & 0,13 \\
\hline 77/1. & 181217 & 77,97 & 22,03 & 39,12 & 0,03 & 0,03 & 0,05 & & & 58 & 0,13 \\
\hline & 1812 & 78,33 & &, 57 & bd & bd & bd & & & 58 & 0,12 \\
\hline & 1812 & 77,81 & 22,19 & 39,14 & $b d$ & 0,02 & 0,04 & ,54 & & ,43 & 0,15 \\
\hline /3. & 181217 & 77,99 & 22,01 & 39,94 & 0,05 & 0,02 & bd & 20,42 & 0,44 & 40,57 & 0,11 \\
\hline 81/4. & 181217 & 77,79 & 22,21 & 39,35 & 0,10 & bd & 0,04 & 20,37 & 0,40 & 40,01 & 0,30 \\
\hline $81 / 5$ & 181217 & 78,01 & 21,99 & 38,24 & 0,10 & 0,04 & 0,01 & 19,54 & 0,29 & 38,89 & 1,20 \\
\hline $81 / 6$ & 181217 & 77,92 & 22,08 & 40,15 & 0,03 & 0,04 & 0,02 & 20,46 & 0,4 & 40,47 & 0,14 \\
\hline 81/7. & 181217 & 78,17 & 21,83 & 40,25 & 0,03 & 0,04 & 0,02 & 0,32 & 0,41 & 40,79 & 0,10 \\
\hline $81 / 8$ & 181217 & 78,03 & 21,97 & 39,51 & bd & bd & 0,02 & 20,29 & 0,44 & 40,42 & 0,11 \\
\hline 81/11. & 181217 & 78,90 & 21,10 & 39,54 & 0,30 & bd & 0,03 & 19,32 & 0,45 & 40,54 & 0,15 \\
\hline $81 / 12$ & & 78,12 & 21,88 & & 0,44 & 0,05 & 0,02 & & 0,42 & 39,61 & 0,18 \\
\hline & & 78,70 & & & 0,06 & 0,03 & 0,02 & 19,65 & 0,43 & & 0,16 \\
\hline & & 78,7 & & 39,69 & 0,2 & 0,03 & bd & & 0 , & & 0,35 \\
\hline & 1812 & 78,18 & & & 0,06 & 0,01 & 0,01 & & & & , 13 \\
\hline & 1812 & 78,31 & 21,69 & 39,75 & 0,02 & 0,01 & 0,04 & 20,22 & & 40,91 & 0,11 \\
\hline $81 / 20$ & 181217 & 77,86 & 22,1 & 38,44 & 0,11 & 0,02 & 0,03 & 19,39 & 0,4 & 38,25 & 1,31 \\
\hline $81 / 22$ & 181217 & 78,44 & 21,56 & 39,55 & 0,06 & 0,04 & 0,01 & 20,16 & 0,4 & 41,14 & 0,16 \\
\hline $81 / 24$ & 181217 & 78,28 & 21,72 & 39,89 & 0,03 & bd & 0,06 & 20,12 & 0,4 & 40,70 & 0,11 \\
\hline $81 / 25$ & 181217 & 78,01 & 21,99 & 39,91 & bd & bd & 0,05 & 20,39 & 0,33 & 40,57 & 0,16 \\
\hline $81 / 26$ & 181217 & 78,27 & 21,73 & 39,81 & bd & 0,02 & 0,04 & 20,15 & 0,33 & 40,75 & 0,09 \\
\hline $81 / 27$ & 181217 & 78,44 & 21,56 & 39,96 & bd & 0,05 & 0,02 & 19,96 & 0,46 & 40,71 & 0,07 \\
\hline $81 / 28$ & 181217 & 78,37 & 21,63 & 39,09 & 0,20 & 0,02 & bd & 19,72 & 0,37 & 40,09 & 0,17 \\
\hline $81 / 29$ & 181217 & 78,65 & 21,35 & 38,92 & bd & 0,05 & 0,03 & 19,60 & 0,36 & 40,52 & 0,13 \\
\hline & 181217 & 18,21 & 21,73 & 39,82 & 0,02 & 0,03 & bd & 20,06 & 0,36 & 40,54 & 政 \\
\hline
\end{tabular}




\begin{tabular}{|c|c|c|c|c|c|c|c|c|c|c|c|}
\hline 81/31. & 181217 & 77,95 & 22,05 & 40,13 & 0,02 & 0,01 & 0,04 & 20,50 & 0,36 & 40,67 & 0,12 \\
\hline $81 / 32$ & 181217 & 78,17 & 21,83 & 39,75 & 0,05 & 0,04 & 0,01 & 20,23 & 0,40 & 40,67 & 0,18 \\
\hline 81/33. & 181217 & 77,79 & 22,21 & 39,46 & 0,01 & 0,02 & 0,03 & 20,48 & 0,37 & 40,23 & 1 \\
\hline $81 / 34$ & 181217 & 78,19 & 21,81 & 39,36 & bd & bd & 0,09 & 20,37 & 0,40 & 40,95 & , \\
\hline $81 / 35$ & 81217 & 78,14 & 21,86 & 39,94 & 0,03 & 0,03 & 0,02 & 20,34 & 0,38 & 40,80 & \\
\hline $81 / 36$ & 181217 & 78,23 & 21,77 & 40,16 & 0,01 & 0,02 & 0,07 & 20,24 & 0,43 & 40,84 & \\
\hline $81 / 37$ & 181217 & 78,32 & 21,68 & 39,64 & 0,02 & 0,04 & 0,07 & 20,22 & 0,36 & 40,95 & \\
\hline $81 / 38$ & 81217 & 78,76 & 21,24 & 39,73 & bd & 0,02 & 0,10 & 19,68 & 0,47 & 40,93 & \\
\hline $81 / 60$ & 181217 & 78,56 & 21,44 & 39,21 & 0,03 & 0,03 & 0,16 & 19,85 & 0,31 & 40,80 & \\
\hline $81 / 61$. & 181217 & 78,42 & 21,58 & 39,82 & 0,01 & 0,03 & 0,06 & 20,08 & 0,43 & 40,95 & \\
\hline $81 / 62$ & 181217 & 78,50 & 21,50 & 39,54 & bd & 0,02 & 0,06 & 20,07 & 0,39 & 41,13 & \\
\hline $81 / 63$. & 181217 & 77,55 & 22,45 & 38,83 & 0,14 & 0,02 & 0,04 & 20,88 & 0,39 & 40,46 & \\
\hline $81 / 64$ & 181217 & 78,54 & 21,46 & 38,88 & 0,03 & 0,01 & 0,02 & 19,94 & 0,47 & 40,92 & \\
\hline $81 / 65$ & 181217 & 78,60 & 21,40 & 38,85 & bd & 0,05 & 0,04 & 19,99 & 0,41 & 41,19 & \\
\hline $81 / 66$ & 181217 & 78,74 & 21,26 & 39,09 & 0,02 & 0,05 & 0,02 & 19,79 & 0,40 & 41,12 & \\
\hline $81 / 67$. & 181217 & 78,14 & 21,86 & 38,96 & 0,02 & 0,04 & 0,03 & 20,37 & 0,40 & 40,87 & \\
\hline $81 / 69$. & 81217 & 78,37 & 21,63 & 38,55 & bd & bd & bd & 20,21 & 0,44 & 41,06 & \\
\hline 81/70. & 181217 & 78,22 & 21,78 & 39,27 & 0,08 & 0,09 & $\mathrm{bd}$ & 20,39 & 0,43 & 41,11 & \\
\hline 81/71. & 181217 & 77,88 & 22,12 & 39,40 & bd & bd & 0,01 & 20,52 & 0,43 & 40,52 & \\
\hline $81 / 72$ & 181217 & 78,06 & 21,94 & 39,34 & $\mathrm{bd}$ & bd & 0,01 & 20,37 & 0,35 & 40,64 & \\
\hline $81 / 80$ & 181217 & 78,32 & 21,68 & 39,54 & 0,03 & 0,06 & 0,06 & 20,16 & 0,45 & 40,85 & , \\
\hline $81 / 81$ & 181217 & 78,22 & 21,78 & 39,68 & 0,01 & 0,03 & 0,01 & 20,27 & 0,40 & 40,89 & \\
\hline $81 / 82$ & 181217 & 77,97 & 22,03 & 39,47 & 0,04 & 0,01 & 0,05 & 20,57 & 0,39 & 40,87 & \\
\hline $81 / 83$ & 181217 & 78,59 & 21,41 & 39,47 & bd & bd & 0,01 & 19,97 & 0,44 & 41,11 & \\
\hline $81 / 84$ & 181217 & 78,84 & 21,16 & 39,16 & 0,02 & $b d$ & 0,04 & 19,68 & 0,41 & 41,16 & \\
\hline $81 / 85$ & 181217 & 78,26 & 21,74 & 38,50 & bd & 0,04 & 0,01 & 20,09 & 0,46 & 40,56 & \\
\hline $81 / 86$ & 81217 & 77,81 & 22,19 & 39,37 & bd & 0,04 & bd & 20,71 & 0,45 & 40,74 & \\
\hline $81 / 87$ & 7 & 79,14 & 20,86 & 37,92 & bd & bd & 0,02 & 13 & 0,41 & 40,70 & \\
\hline $81 / 88$ & 181217 & 78,01 & 21,99 & 39,19 & 0,04 & 0,03 & 0,04 & 20,43 & 0,44 & 40,68 & \\
\hline $81 / 89$ & 1812 & 77,88 & 22,12 & 39,14 & 0,02 & 0,03 & bd & 20,63 & 0,41 & 40,76 & 0,1 \\
\hline $81 / 90$. & 181217 & 78,29 & 21,71 & 39,37 & 0,05 & 0,06 & 0,03 & 20,15 & 0,40 & 40,75 & ) \\
\hline 81/91. & 181217 & 78,36 & 21,64 & 39,24 & bd & $\mathrm{bd}$ & 0,01 & 20,16 & 0,43 & 40,97 & 0,1 \\
\hline $81 / 92$. & 181217 & 78,15 & 21,85 & 39,40 & 0,01 & 0,03 & 0,01 & 20,46 & 0,42 & 41,08 & 0,1 \\
\hline 81/93. & 181217 & 78,18 & 21,82 & 39,19 & 0,05 & 0,02 & 0,02 & 20,43 & 0,43 & 41,03 & 0,1 \\
\hline $81 / 94$. & 181217 & 77,75 & 22,25 & 39,61 & bd & 0,02 & 0,02 & 20,78 & 0,41 & 40,75 & , \\
\hline $81 / 95$. & 181 & 77,81 & 22,19 & 39,29 & bc & 0,03 & 0,05 & 20,72 & 0,4 & 40,73 & \\
\hline $81 / 96$. & & 78,01 & 21,99 & 39,70 & bd & 0,02 & 0,08 & 20,38 & 0, & 40,58 & \\
\hline 81/97. & & 78, & & & 0,02 & 0,02 & 17 & & & ,04 & \\
\hline 81/100. & 181 & 77,97 & 22,03 & 39,01 & bd & 0,03 & 0,14 & 20,52 & 0,34 & 40,69 & 0 , \\
\hline $82 / 1$ & 181 & 77,76 & 22,24 & 39,56 & 0,03 & bd & 0,02 & 20,66 & 0,40 & 40,53 & 0,1 \\
\hline $82 / 2$ & 181217 & 78,24 & 21,76 & 39,54 & bd & 0,04 & 0,02 & 20,14 & 0,41 & 40,61 & \\
\hline $82 / 3$ & 181217 & 78,09 & 21,91 & 39,62 & 0,02 & 0,02 & bd & 20,29 & 0,42 & 40,55 & \\
\hline $82 / 4$ & 181217 & 77,63 & 22,37 & 39,69 & 0,05 & 0,04 & 0,06 & 20,93 & 0,39 & 40,77 & 0,1 \\
\hline $82 / 5$ & 181217 & 78,07 & 21,93 & 39,33 & 0,09 & 0,03 & 0,04 & 20,29 & 0,42 & 40,49 & 0,1 \\
\hline $82 / 6$ & 181217 & 78,12 & 21,88 & 39,45 & 0,05 & 0,01 & 0,03 & 20,31 & 0,38 & 40,72 & 0,1 \\
\hline $82 / 7$ & 181217 & 77,87 & 22,13 & 39,11 & 0,11 & bd & 0,04 & 20,36 & 0,42 & 40,20 & 0,1 \\
\hline $82 / 8$ & & 78,30 & 21,70 & 39,67 & 0,09 & bd & 0,03 & 19,94 & 0,44 & 40,37 & \\
\hline $82 / 9$ & & 78,09 & 21,91 & 39,49 & 0,05 & 0,01 & 0,06 & 20,21 & 0,42 & 40,43 & \\
\hline $82 / 10$ & & 78,17 & 21 & 39,57 & 0,05 & 0,03 & 0,01 & 20,08 & 0,41 & 40,31 & \\
\hline 82/11. & & 77,62 & 22 , & & 0,03 & 0,03 & 0,02 & & 0,3 & 40,75 & \\
\hline $82 / 12$ & 18121 & 78,03 & 21,97 & 40,05 & 0,02 & 0,01 & 0,03 & 20,45 & 0,4 & 40,72 & \\
\hline $82 / 13$ & 181217 & 77,91 & 22,09 & 39,58 & 0,07 & 0,02 & 0,07 & 20,34 & 0,41 & 40,26 & \\
\hline $82 / 14$ & 181217 & 78,15 & 21,85 & 39,15 & 0,06 & bd & 0,05 & 20,23 & 0,42 & 40,61 & \\
\hline $82 / 15$ & 181217 & 78,14 & 21,86 & 39,06 & 0,02 & 0,01 & 0,02 & 20,19 & 0,40 & 40,51 & 0 , \\
\hline $82 / 16$ & 181217 & 77,88 & 22,12 & 38,26 & 0,13 & 0,01 & 0,04 & 19,69 & 0,45 & 38,92 & \\
\hline $82 / 21$ & 181217 & 78,02 & 21,98 & 39,27 & 0,05 & 0,02 & 0,04 & 20,47 & 0,45 & 40,73 & \\
\hline $82 / 22$ & 181217 & 77,95 & 22,05 & 39,20 & 0,07 & 0,02 & 0,02 & 20,67 & 0,26 & 40,99 & 0 , \\
\hline $82 / 23$ & 181217 & 77,93 & 22,07 & 39,33 & 0,04 & 0,02 & 0,03 & 20,36 & 0,36 & 40,30 & 0,1 \\
\hline $82 / 24$ & 181217 & 77,90 & 22,10 & 38,86 & 0,02 & bd & 0,04 & 20,57 & 0,41 & 40,67 & 0,1 \\
\hline
\end{tabular}




\begin{tabular}{|c|c|c|c|c|c|c|c|c|c|c|c|}
\hline $82 / 25$ & 181217 & 78,19 & 21,81 & 39,15 & 0,03 & $b d$ & 0,03 & 20,18 & 0,43 & 40,58 & 0,18 \\
\hline $82 / 26$ & 181217 & 77,58 & 22,42 & 39,12 & 0,05 & bd & 0,02 & 20,73 & 0,52 & 40,22 & 0,14 \\
\hline $82 / 27$ & 181217 & 78,01 & 21,99 & 38,79 & 0,02 & bd & $\mathrm{bd}$ & 20,38 & 0,38 & 40,57 & 2 \\
\hline $82 / 28$ & 181217 & 77,94 & 22,06 & 39,57 & $\mathrm{bd}$ & 0,03 & 0,05 & 20,51 & 0,33 & 40,61 & ل \\
\hline $82 / 29$ & 181217 & 77,91 & 22,09 & 39,53 & 0,05 & bd & 0,05 & 20,51 & 0,39 & 40,54 & \\
\hline $82 / 30$ & 181217 & 77,95 & 22,05 & 39,28 & 0,02 & 0,02 & 0,04 & 20,37 & 0,33 & 40,42 & \\
\hline 82/31. & 81217 & 77,75 & 22,25 & 39,45 & bd & 0,05 & 0,01 & 20,77 & 0,40 & 40,70 & \\
\hline 82/32. & 181217 & 78,22 & 21,78 & 38,93 & 0,07 & 0,02 & 0,05 & 19,98 & 0,40 & 40,27 & \\
\hline $82 / 33$ & 181217 & 77,62 & 22,38 & 39,24 & 0,03 & 0,02 & 0,02 & 20,82 & 0,45 & 40,52 & \\
\hline $82 / 34$ & 181217 & 78,82 & 21,18 & 37,81 & bd & $\mathrm{bd}$ & 0,05 & 19,36 & 0,34 & 40,44 & b, \\
\hline $82 / 35$ & 181217 & 77,86 & 22,14 & 39,73 & 0,02 & bd & 0,02 & 20,59 & 0,39 & 40,60 & \\
\hline $82 / 36$ & 181217 & 78,07 & 21,93 & 39,18 & 0,01 & 0,01 & 0,04 & 20,43 & 0,42 & 40,78 & \\
\hline $82 / 37$ & 181217 & 78,24 & 21,76 & 38,42 & 0,04 & 0,01 & 0,02 & 20,08 & 0,42 & 40,50 & \\
\hline $82 / 38$ & 181217 & 78,05 & 21,95 & 39,21 & 0,05 & 0,01 & 0,06 & 20,46 & 0,48 & 40,78 & \\
\hline $82 / 39$ & 181217 & 77,62 & 22,38 & 39,36 & 0,02 & 0,03 & 0,01 & 20,79 & 0,41 & 40,47 & \\
\hline $82 / 40$ & 181217 & 77,76 & 22,24 & 39,38 & 0,04 & 0,01 & bd & 20,51 & 0,41 & 40,25 & \\
\hline 82/41. & 181217 & 78,15 & 21,85 & 39,31 & 0,02 & $\mathrm{bd}$ & 0,01 & 20,25 & 0,39 & 40,67 & \\
\hline $82 / 42$ & 181217 & 78,25 & 21,75 & 39,11 & $\mathrm{bd}$ & bd & 0,03 & 20,08 & 0,45 & 40,51 & \\
\hline 82/43. & 181217 & 78,02 & 21,98 & 38,99 & 0,01 & bd & 0,02 & 20,51 & 0,57 & 40,86 & \\
\hline $82 / 44$. & 181217 & 77,94 & 22,06 & 39,38 & $\mathrm{bd}$ & $b d$ & bd & 20,66 & 0,41 & 40,96 & , \\
\hline $82 / 45$ & 181217 & 78,08 & 21,92 & 39,83 & 0,05 & bd & 0,05 & 20,32 & 0,33 & 40,61 &, 1 \\
\hline $82 / 47$. & 181217 & 78,27 & 21,73 & 39,44 & 0,06 & 0,01 & 0,02 & 20,05 & 0,39 & 40,53 & , \\
\hline $82 / 48$ & 181217 & 78,01 & 21,99 & 39,33 & 0,03 & 0,01 & 0,02 & 20,43 & 0,37 & 40,67 & \\
\hline $82 / 49$. & 181217 & 78,04 & 21,96 & 39,38 & bd & 0,05 & 0,04 & 20,50 & 0,54 & 40,87 & \\
\hline $82 / 50$. & 181217 & 77,81 & 22,19 & 39,54 & 0,04 & 0,02 & 0,02 & 20,68 & 0,42 & 40,67 & \\
\hline 82/51. & 181217 & 78,16 & 21,84 & 39,23 & 0,11 & $\mathrm{bd}$ & 0,02 & 20,13 & 0,35 & 40,42 & \\
\hline $82 / 52$ & 181 & 77,85 & 22,15 & 39,50 & bd & 0,02 & 0,02 & 20,62 & 0,44 & 40,65 & \\
\hline $82 / 53$ & 181217 & 78,04 & 21,96 & 38,83 & 0,05 & 0,01 & 0,07 & 20,37 & 0,47 & 40,59 & \\
\hline $82 / 56$ & 181217 & 78,12 & 21,88 & 39,34 & bd & 0,05 & bd & 20,33 & 0,44 & 40,72 & 0,1 \\
\hline $82 / 57$ & 181217 & 78,09 & 21,91 & 39,31 & $\mathrm{bd}$ & bd & 0,02 & 20,19 & 0,48 & 40,40 & , \\
\hline $82 / 58$. & 181217 & 78,20 & 21,80 & 39,40 & 0,01 & 0,02 & 0,06 & 20,11 & 0,37 & 40,47 & \\
\hline $82 / 59$ & 181217 & 77,88 & 22,12 & 39,41 & 0,09 & 0,03 & 0,07 & 20,62 & 0,40 & 40,71 & 0,1 \\
\hline $82 / 60$ & 181217 & 77,88 & 22,12 & 39,50 & 0,03 & 0,02 & 0,03 & 20,46 & 0,41 & 40,39 & 0,2 \\
\hline 82/61. & 181217 & 77,79 & 22,21 & 39,70 & bd & 0,02 & 0,02 & 20,79 & 0,38 & 40,84 &, 1 \\
\hline $82 / 62$ & 181217 & 79,17 & 20,83 & 38,80 & 0,35 & 0,03 & 0,04 & 18,79 & 0,43 & 40,02 & \\
\hline $82 / 64$ & 17 & 78,05 & 21, & 39,60 & 0,06 & 0,04 & 0,04 & 20,11 & 0, & 0,09 & \\
\hline $82 / 65$ & & 78,06 & & & 0,01 & 0,03 & 04 & & 40 & ,65 & \\
\hline $82 / 66$ & 181 & 77,58 & 22,42 & 39,16 & 0,01 & bd & 0,05 & 20,88 & 0,37 & 40,51 & 0,1 \\
\hline $82 / 67$. & 181217 & 77,76 & 22,24 & 39,72 & 0,02 & $\mathrm{bd}$ & 0,04 & 20,68 & 0,35 & 40,56 & 0, \\
\hline $82 / 68$ & 181217 & 78,13 & 21,87 & 39,37 & 0,01 & 0,01 & 0,04 & 20,04 & 0,34 & 40,17 & , \\
\hline $82 / 69$. & 181217 & 77,88 & 22,12 & 39,51 & 0,03 & 0,02 & 0,04 & 20,55 & 0,36 & 40,57 & 0,2 \\
\hline 82/70. & 181217 & 77,75 & 22,25 & 39,70 & 0,04 & 0,02 & 0,04 & 20,62 & 0,35 & 40,43 & 0,2 \\
\hline 82/71. & 181217 & 78,21 & 21,79 & 39,91 & 0,05 & 0,06 & 0,03 & 20,11 & 0,45 & 40,51 & 0,1 \\
\hline 82/72. & 181217 & 77,76 & 22,24 & 39,34 & 0,03 & 0,02 & 0,05 & 20,66 & 0,44 & 40,50 & 0,1 \\
\hline 82/73. & 181217 & 78,13 & 21,87 & 39,48 & 0,04 & 0,02 & bd & 20,18 & 0,44 & 40,49 & ). \\
\hline $82 / 75$ & 81217 & 78,11 & 21,89 & 38,10 & 0,23 & 0,02 & bd & 19,71 & 0,34 & 39,41 & \\
\hline $82 / 76$ & & 78,15 & 21,85 & 39,43 & 0,08 & 0,04 & 0,05 & 20,01 & 0,34 & 40,13 & \\
\hline $82 / 77$ & & 78,06 & & 39,40 & 0,03 & bd & 0,05 & 20,45 & 0,4 & 40,84 & 0 \\
\hline 82/78. & 1812 & 78,08 & 21,92 & 39,11 & 0,05 & 0,04 & 0,08 & 20,36 & 0,4 & 40,73 & 0 \\
\hline 82/79. & 181217 & 78,28 & 21,72 & 39,24 & 0,04 & 0,01 & 0,04 & 20,08 & 0,5 & 40,56 & 0 \\
\hline $82 / 80$. & 181217 & 78,30 & 21,70 & 39,18 & 0,04 & 0,03 & 0,01 & 19,59 & 0,34 & 39,68 & 0,2 \\
\hline 82/81. & 181217 & 77,87 & 22,13 & 39,97 & bd & 0,02 & bd & 20,70 & 0,33 & 40,89 & 0,1 \\
\hline 82/82. & 181217 & 77,87 & 22,13 & 39,44 & 0,01 & 0,01 & bd & 20,61 & 0,41 & 40,69 & 0,1 \\
\hline 82/83. & 181217 & 77,77 & 22,23 & 39,60 & 0,02 & 0,03 & 0,03 & 20,71 & 0,37 & 40,67 & 0,2 \\
\hline $82 / 84$ & 181217 & 78,05 & 21,95 & 39,43 & 0,05 & 0,02 & 0,06 & 20,51 & 0,41 & 40,87 & \\
\hline $82 / 85$ & 181217 & 78,22 & 21,78 & 38,93 & 0,01 & 0,04 & 0,06 & 20,26 & 0,35 & 40,82 & 0,2 \\
\hline $82 / 86$ & 181217 & 78,04 & 21,96 & 39,63 & 0,03 & 0,04 & 0,04 & 20,25 & 0,39 & 40,39 & 0,1 \\
\hline $82 / 87$. & 181217 & 77,93 & 22,07 & 39,37 & 0,02 & bd & 0,04 & 20,53 & 0,43 & 40,67 & 0,1 \\
\hline $82 / 88$ & 181217 & 78,40 & 21,60 & 39,39 & 0,01 & 0,01 & 0,03 & 20,09 & 0,42 & 40,93 & 0,2 \\
\hline
\end{tabular}




\begin{tabular}{|c|c|c|c|c|c|c|c|c|c|c|c|}
\hline 82/89. & 181217 & 78,53 & 21,47 & 39,09 & 0,06 & 0,02 & 0,02 & 19,94 & 0,36 & 40,92 & 0,14 \\
\hline 82/91. & 181217 & 78,19 & 21,81 & 39,53 & 0,07 & 0,02 & 0,01 & 20,25 & 0,35 & 40,75 & 0,14 \\
\hline $82 / 92$ & 181217 & 78,02 & 21,98 & 39,36 & 0,03 & 0,04 & 0,07 & 20,50 & 0,45 & 40,79 & 0,16 \\
\hline $82 / 93$. & 181217 & 77,85 & 22,15 & 39,41 & $\mathrm{bd}$ & bd & 0,02 & 20,74 & 0,42 & 40,86 & 0,17 \\
\hline 82/94. & 181217 & 78,15 & 21,85 & 39,51 & 0,02 & 0,03 & 0,03 & 20,32 & 0,35 & 40,80 & 0,12 \\
\hline $82 / 95$. & 181217 & 77,89 & 22,11 & 39,30 & 0,04 & 0,03 & 0,09 & 20,60 & 0,41 & 40,71 & 0,17 \\
\hline $82 / 96$ & 181217 & 78,14 & 21,86 & 39,55 & 0,02 & 0,05 & 0,03 & 20,40 & 0,34 & 40,88 & 0,18 \\
\hline 82/97. & 181217 & 78,09 & 21,91 & 39,05 & 0,01 & 0,02 & 0,03 & 20,25 & 0,46 & 40,45 & 0,13 \\
\hline $82 / 98$ & 181217 & 78,30 & 21,70 & 39,68 & bd & 0,02 & 0,03 & 20,25 & 0,48 & 40,96 & 0,23 \\
\hline 82/99. & 181217 & 77,88 & 22,12 & 39,40 & 0,03 & 0,01 & 0,02 & 20,48 & 0,42 & 40,44 & 0,16 \\
\hline 82/100. & 181217 & 77,77 & 22,23 & 39,60 & 0,05 & 0,02 & 0,06 & 20,68 & 0,36 & 40,56 & 0,15 \\
\hline 99/1. & 181217 & 78,81 & 21,19 & 40,19 & 0,04 & 0,03 & 0,14 & 19,66 & 0,32 & 41,02 & 0,21 \\
\hline 99/2. & 181217 & 78,62 & 21,38 & 39,99 & 0,01 & bd & 0,07 & 19,67 & 0,36 & 40,58 & 0,19 \\
\hline 99/3. & 181217 & 78,45 & 21,55 & 39,69 & 0,03 & 0,01 & 0,15 & 19,71 & 0,46 & 40,26 & 0,24 \\
\hline 99/4. & 181217 & 78,49 & 21,51 & 40,03 & 0,03 & 0,04 & 0,14 & 20,09 & 0,41 & 41,13 & 0,13 \\
\hline 99/5. & 181217 & 78,84 & 21,16 & 39,73 & 0,02 & bd & 0,18 & 19,82 & 0,42 & 41,42 & 0,07 \\
\hline 99/6. & 181217 & 79,21 & 20,79 & 39,89 & 0,05 & bd & 0,26 & 19,39 & 0,33 & 41,40 & 0,07 \\
\hline 99/7. & 181217 & 79,72 & 20,28 & 39,70 & $\mathrm{bd}$ & bd & 0,29 & 18,88 & 0,36 & 41,61 & 0,17 \\
\hline $99 / 8$ & 181217 & 79,67 & 20,33 & 39,87 & 0,05 & bd & 0,38 & 19,00 & 0,39 & 41,80 & 0,16 \\
\hline 139/1. & 181217 & 78,03 & 21,97 & 39,78 & 0,04 & 0,03 & 0,01 & 20,43 & 0,32 & 40,70 & 0,11 \\
\hline 142/1. & 181217 & 78,19 & 21,81 & 40,11 & 0,02 & 0,02 & 0,04 & 20,27 & 0,48 & 40,77 & 0,13 \\
\hline 145/1. & 181217 & 78,09 & 21,91 & 40,39 & 0,06 & 0,01 & 0,03 & 20,40 & 0,45 & 40,76 & 0,10 \\
\hline $145 / 5$ & 181217 & 77,84 & 22,16 & 40,45 & 0,05 & 0,01 & bd & 20,69 & 0,47 & 40,80 & 0,10 \\
\hline $145 / 6$ & 181217 & 77,89 & 22,11 & 40,24 & $\mathrm{bd}$ & 0,05 & 0,04 & 20,67 & 0,43 & 40,84 & 0,10 \\
\hline $145 / 8$ & 181217 & 77,85 & 22,15 & 40,14 & $b d$ & 0,04 & 0,05 & 20,50 & 0,41 & 40,41 & 0,25 \\
\hline $145 / 9$ & 181217 & 78,18 & 21,82 & 40,13 & 0,05 & 0,03 & 0,05 & 20,32 & 0,42 & 40,82 & 0,13 \\
\hline 145/11. & 181217 & 78,33 & 21,67 & 40,30 & 0,02 & 0,04 & 0,03 & 20,10 & 0,42 & 40,74 & 0,11 \\
\hline 145/12. & 181217 & 78,32 & 21,68 & 39,83 & 0,06 & 0,03 & 0,03 & 20,05 & 0,42 & 40,64 & 0,15 \\
\hline 145/13. & 181217 & 77,91 & 22,09 & 40,00 & 0,04 & $\mathrm{bd}$ & 0,03 & 20,48 & 0,31 & 40,51 & 0,14 \\
\hline 145/14. & 181217 & 77,94 & 22,06 & 39,56 & 0,54 & 0,02 & 0,06 & 20,22 & 0,36 & 40,11 & 0,26 \\
\hline 145/15. & 181217 & 78,08 & 21,92 & 38,92 & 0,50 & 0,05 & 0,05 & 20,01 & 0,41 & 39,95 & 0,38 \\
\hline $145 / 67$. & 181217 & 78,05 & 21,95 & 39,26 & 0,05 & 0,02 & 0,03 & 20,36 & 0,43 & 40,62 & 0,35 \\
\hline $145 / 68$ & 181217 & 77,68 & 22,32 & 39,38 & 0,02 & bd & 0,03 & 20,81 & 0,41 & 40,64 & 0,15 \\
\hline 145/70. & 181217 & 78,23 & 21,77 & 39,78 & 0,01 & 0,04 & 0,04 & 20,07 & 0,41 & 40,49 & 0,15 \\
\hline 145/71. & 181217 & 78,14 & 21,86 & 39,91 & bd & bd & 0,03 & 20,22 & 0,32 & 40,56 & 0,18 \\
\hline 148/1. & 181217 & 78,24 & 21,76 & 39,49 & 0,03 & 0,03 & 0,05 & 20,18 & 0,35 & 40,73 & 0,19 \\
\hline $148 / 2$ & 181217 & 78,34 & 21,66 & 39,74 & 0,13 & 0,03 & bd & 19,81 & 0,41 & 40,18 & 0,18 \\
\hline $148 / 3$ & 181217 & 77,92 & 22,08 & 39,64 & 0,07 & 0,02 & 0,05 & 20,46 & 0,45 & 40,46 & 0,21 \\
\hline $148 / 4$ & 181217 & 78,38 & 21,62 & 39,03 & 0,20 & 0,02 & 0,03 & 19,91 & 0,44 & 40,50 & 0,13 \\
\hline $148 / 5$ & 181217 & 78,27 & 21,73 & 39,73 & 0,20 & $\mathrm{bd}$ & 0,06 & 19,87 & 0,40 & 40,18 & 0,13 \\
\hline $148 / 6$ & 181217 & 78,26 & 21,74 & 39,99 & 0,06 & 0,07 & 0,02 & 20,20 & 0,49 & 40,78 & 0,09 \\
\hline $148 / 7$ & 181217 & 78,38 & 21,62 & 39,59 & 0,07 & 0,03 & $\mathrm{bd}$ & 19,96 & 0,40 & 40,57 & 0,17 \\
\hline $148 / 8$ & 181217 & 78,70 & 21,30 & 38,53 & 0,40 & 0,01 & 0,01 & 19,06 & 0,45 & 39,47 & 0,22 \\
\hline $148 / 9$ & 181217 & 77,92 & 22,08 & 39,93 & 0,14 & 0,01 & 0,02 & 20,44 & 0,40 & 40,48 & 0,13 \\
\hline 148/10. & 181217 & 78,05 & 21,95 & 39,50 & 0,07 & 0,01 & 0,04 & 20,40 & 0,36 & 40,67 & 0,09 \\
\hline 148/11. & 181217 & 78,37 & 21,63 & 39,82 & 0,02 & 0,01 & 0,02 & 20,21 & 0,47 & 41,06 & 0,14 \\
\hline 148/12. & 181217 & 77,80 & 22,20 & 40,28 & bd & 0,04 & 0,01 & 20,70 & 0,42 & 40,71 & 0,13 \\
\hline 148/13. & 181217 & 77,80 & 22,20 & 40,34 & 0,02 & bd & 0,05 & 20,70 & 0,41 & 40,71 & 0,09 \\
\hline 148/14. & 181217 & 77,96 & 22,04 & 39,88 & $\mathrm{bd}$ & bd & 0,02 & 20,41 & 0,41 & 40,53 & 0,10 \\
\hline 148/15. & 181217 & 77,83 & 22,17 & 39,90 & $b d$ & 0,04 & 0,04 & 20,70 & 0,40 & 40,77 & 0,13 \\
\hline 148/16. & 181217 & 77,77 & 22,23 & 39,84 & 0,06 & 0,04 & 0,01 & 20,70 & 0,41 & 40,63 & 0,13 \\
\hline 148/17. & 181217 & 77,83 & 22,17 & 39,68 & 0,04 & 0,01 & $\mathrm{bd}$ & 20,60 & 0,38 & 40,57 & 0,15 \\
\hline 148/18. & 181217 & 78,01 & 21,99 & 39,44 & 0,03 & 0,01 & 0,05 & 20,47 & 0,39 & 40,74 & 0,12 \\
\hline 148/19. & 181217 & 78,07 & 21,93 & 39,90 & 0,03 & 0,03 & 0,02 & 20,36 & 0,42 & 40,66 & 0,11 \\
\hline 148/20. & 181217 & 77,71 & 22,29 & 39,47 & bd & 0,02 & 0,04 & 20,71 & 0,46 & 40,54 & 0,12 \\
\hline 148/21. & 181217 & 78,35 & 21,65 & 39,31 & 0,02 & 0,02 & 0,02 & 19,92 & 0,48 & 40,48 & 0,14 \\
\hline 148/22. & 181217 & 77,80 & 22,20 & 39,86 & 0,03 & bd & 0,02 & 20,66 & 0,47 & 40,58 & 0,12 \\
\hline 148/23. & 181217 & 78,22 & 21,78 & 39,78 & 0,02 & 0,02 & 0,04 & 20,27 & 0,35 & 40,84 & 0,09 \\
\hline $148 / 25$ & 181217 & 78,11 & 21,89 & 39,36 & 0,37 & bd & 0,06 & 20,07 & 0,44 & 40,21 & 0,18 \\
\hline
\end{tabular}




\begin{tabular}{|c|c|c|c|c|c|c|c|c|c|c|c|}
\hline $148 / 26$ & 181217 & 77,73 & 22,27 & 39,99 & 0,04 & 0,03 & 0,03 & 20,75 & 0,40 & 40,62 & 0,17 \\
\hline 148/27. & 181217 & 77,85 & 22,15 & 39,87 & 0,02 & $\mathrm{bd}$ & 0,03 & 20,72 & 0,36 & 40,84 & 0,14 \\
\hline $148 / 28$ & 181217 & 77,89 & 22,11 & 39,74 & $\mathrm{bd}$ & bd & $\mathrm{bd}$ & 20,50 & 0,46 & 40,53 & 0,20 \\
\hline 148/29. & 181217 & 77,98 & 22,02 & 39,79 & 0,01 & 0,05 & 0,03 & 20,46 & 0,35 & 40,65 & 0,09 \\
\hline 148/30. & 181217 & 77,57 & 22,43 & 39,61 & 0,06 & 0,04 & 0,05 & 21,08 & 0,43 & 40,93 & 0,12 \\
\hline 148/31. & 181217 & 77,63 & 22,37 & 40,12 & 0,02 & 0,01 & 0,05 & 20,82 & 0,33 & 40,49 & 0,16 \\
\hline 148/32. & 181217 & 78,19 & 21,81 & 39,88 & 0,40 & bd & bd & 19,89 & 0,44 & 40,04 & 0,12 \\
\hline 148/33. & 181217 & 78,34 & 21,66 & 39,42 & 0,65 & bd & 0,01 & 19,66 & 0,36 & 39,87 & 0,16 \\
\hline 148/34. & 181217 & 78,06 & 21,94 & 39,68 & 0,25 & 0,03 & 0,05 & 20,16 & 0,44 & 40,19 & 0,25 \\
\hline 148/35. & 181217 & 77,91 & 22,09 & 39,76 & 0,07 & $\mathrm{bd}$ & $\mathrm{bd}$ & 20,57 & 0,46 & 40,71 & 0,21 \\
\hline 148/36. & 181217 & 78,00 & 22,00 & 39,18 & 0,35 & 0,04 & bd & 20,04 & 0,50 & 39,88 & 0,26 \\
\hline 148/38. & 181217 & 77,87 & 22,13 & 38,68 & 0,73 & $\mathrm{bd}$ & 0,03 & 20,03 & 0,37 & 39,55 & 0,34 \\
\hline 148/39. & 181217 & 77,93 & 22,07 & 39,69 & 0,22 & 0,02 & 0,03 & 20,31 & 0,39 & 40,24 & 0,33 \\
\hline 148/40. & 181217 & 77,92 & 22,08 & 39,72 & 0,26 & 0,04 & 0,02 & 20,29 & 0,39 & 40,21 & 0,28 \\
\hline $148 / 42$ & 181217 & 78,11 & 21,89 & 39,21 & bd & bd & 0,03 & 20,43 & 0,45 & 40,88 & 0,19 \\
\hline 148/43. & 181217 & 78,39 & 21,61 & 39,62 & bd & $b d$ & bd & 19,96 & 0,49 & 40,65 & 0,18 \\
\hline 148/44. & 181217 & 78,38 & 21,62 & 40,15 & $\mathrm{bd}$ & 0,03 & 0,04 & 20,06 & 0,43 & 40,81 & 0,19 \\
\hline $148 / 45$. & 181217 & 77,80 & 22,20 & 40,04 & 0,02 & 0,02 & 0,05 & 20,66 & 0,33 & 40,61 & 0,11 \\
\hline 148/46. & 181217 & 77,64 & 22,36 & 39,82 & 0,12 & 0,03 & 0,03 & 20,77 & 0,51 & 40,47 & 0,12 \\
\hline 148/47. & 181217 & 77,79 & 22,21 & 39,94 & $\mathrm{bd}$ & 0,02 & 0,02 & 20,52 & 0,44 & 40,29 & 0,12 \\
\hline 148/49. & 181217 & 78,04 & 21,96 & 39,72 & 0,05 & 0,02 & 0,02 & 20,27 & 0,42 & 40,38 & 0,21 \\
\hline 148/53. & 181217 & 79,50 & 20,50 & 38,02 & 0,03 & 0,03 & $\mathrm{bd}$ & 18,85 & 0,37 & 41,04 & 0,12 \\
\hline $148 / 54$ & 181217 & 78,73 & 21,27 & 38,64 & $\mathrm{bd}$ & $\mathrm{bd}$ & 0,05 & 19,74 & 0,39 & 40,97 & 0,22 \\
\hline $148 / 55$. & 181217 & 78,01 & 21,99 & 40,11 & bd & 0,04 & 0,07 & 20,44 & 0,43 & 40,71 & 0,14 \\
\hline $148 / 56$. & 181217 & 78,29 & 21,71 & 39,53 & 0,02 & bd & 0,03 & 20,17 & 0,42 & 40,79 & 0,15 \\
\hline 148/57. & 181217 & 78,46 & 21,54 & 40,21 & 0,02 & 0,02 & bd & 19,98 & 0,43 & 40,85 & 0,17 \\
\hline $148 / 58$ & 181217 & 78,05 & 21,95 & 39,46 & 0,14 & 0,02 & bd & 20,30 & 0,49 & 40,53 & 0,14 \\
\hline $148 / 59$. & 181217 & 78,46 & 21,54 & 38,80 & 0,56 & 0,04 & 0,04 & 19,73 & 0,41 & 40,30 & 0,19 \\
\hline 148/60. & 181217 & 78,34 & 21,66 & 39,64 & 0,08 & 0,05 & bd & 19,89 & 0,32 & 40,35 & 0,21 \\
\hline 148/61. & 181217 & 78,77 & 21,23 & 39,52 & 0,08 & 0,04 & 0,03 & 19,74 & 0,36 & 41,09 & 0,13 \\
\hline 148/62. & 181217 & 78,01 & 21,99 & 39,79 & 0,01 & 0,01 & 0,03 & 20,51 & 0,41 & 40,81 & 0,17 \\
\hline 148/63. & 181217 & 78,00 & 22,00 & 39,96 & 0,07 & 0,02 & 0,02 & 20,46 & 0,32 & 40,70 & 0,11 \\
\hline 148/64. & 181217 & 78,48 & 21,52 & 39,75 & 0,26 & 0,02 & 0,03 & 19,67 & 0,37 & 40,20 & 0,17 \\
\hline 148/65. & 181217 & 77,89 & 22,11 & 39,26 & 0,06 & 0,03 & 0,02 & 20,55 & 0,37 & 40,58 & 0,16 \\
\hline 148/66. & 181217 & 78,48 & 21,52 & 39,75 & 0,05 & 0,07 & 0,04 & 20,11 & 0,34 & 41,12 & 0,10 \\
\hline 148/67. & 181217 & 78,33 & 21,67 & 39,26 & 0,37 & bd & bd & 19,91 & 0,34 & 40,32 & 0,17 \\
\hline $148 / 68$ & 181217 & 78,22 & 21,78 & 39,68 & 0,34 & bd & 0,01 & 19,82 & 0,41 & 39,96 & 0,18 \\
\hline 148/69. & 181217 & 77,79 & 22,21 & 39,94 & 0,01 & bd & 0,03 & 20,76 & 0,44 & 40,78 & 0,18 \\
\hline 148/70. & 181217 & 78,39 & 21,61 & 39,93 & $\mathrm{bd}$ & 0,03 & $\mathrm{bd}$ & 20,08 & 0,41 & 40,90 & 0,14 \\
\hline 148/71. & 181217 & 78,10 & 21,90 & 39,90 & $\mathrm{bd}$ & 0,03 & $\mathrm{bd}$ & 20,35 & 0,46 & 40,72 & 0,13 \\
\hline 148/72. & 181217 & 78,25 & 21,75 & 39,60 & bd & $\mathrm{bd}$ & 0,01 & 20,25 & 0,50 & 40,87 & 0,19 \\
\hline 148/74. & 181217 & 78,03 & 21,97 & 39,78 & 0,01 & 0,02 & 0,01 & 20,49 & 0,40 & 40,83 & 0,08 \\
\hline 148/75. & 181217 & 78,13 & 21,87 & 40,01 & 0,04 & 0,03 & bd & 20,25 & 0,44 & 40,62 & 0,19 \\
\hline 148/76. & 181217 & 78,08 & 21,92 & 39,80 & 0,23 & 0,04 & bd & 20,35 & 0,47 & 40,66 & 0,15 \\
\hline 148/77. & 181217 & 77,98 & 22,02 & 39,65 & 0,11 & $\mathrm{bd}$ & 0,06 & 20,07 & 0,50 & 39,89 & 0,30 \\
\hline 148/80. & 181217 & 78,37 & 21,63 & 38,98 & 0,07 & 0,03 & bd & 19,56 & 0,42 & 39,77 & 0,74 \\
\hline 148/81. & 181217 & 78,39 & 21,61 & 39,69 & bd & bd & 0,03 & 19,96 & 0,41 & 40,63 & 0,09 \\
\hline 148/82. & 181217 & 77,49 & 22,51 & 39,04 & 0,49 & 0,03 & bd & 20,19 & 0,39 & 39,03 & 0,73 \\
\hline 148/85. & 181217 & 78,32 & 21,68 & 39,25 & 0,04 & 0,03 & 0,03 & 19,78 & 0,35 & 40,08 & 0,36 \\
\hline 148/86. & 181217 & 77,78 & 22,22 & 39,47 & 0,21 & 0,02 & 0,03 & 20,18 & 0,41 & 39,62 & 0,20 \\
\hline 148/87. & 181217 & 78,17 & 21,83 & 38,89 & 0,13 & 0,02 & $\mathrm{bd}$ & 20,06 & 0,43 & 40,33 & 0,25 \\
\hline $148 / 88$ & 181217 & 77,88 & 22,12 & 39,99 & 0,05 & 0,01 & 0,03 & 20,56 & 0,41 & 40,62 & 0,16 \\
\hline 148/89. & 181217 & 77,83 & 22,17 & 39,63 & 0,01 & 0,02 & 0,01 & 20,66 & 0,41 & 40,65 & 0,15 \\
\hline 148/90. & 181217 & 77,98 & 22,02 & 39,91 & 0,01 & bd & $\mathrm{bd}$ & 20,52 & 0,45 & 40,81 & 0,20 \\
\hline 148/91. & 181217 & 77,91 & 22,09 & 39,85 & bd & 0,04 & bd & 20,51 & 0,39 & 40,61 & 0,18 \\
\hline 148/92. & 181217 & 77,94 & 22,06 & 40,23 & 0,03 & 0,07 & 0,05 & 20,44 & 0,36 & 40,51 & 0,16 \\
\hline 148/94. & 181217 & 78,10 & 21,90 & 39,78 & bd & 0,02 & 0,05 & 20,41 & 0,41 & 40,83 & 0,22 \\
\hline 148/95. & 181217 & 77,98 & 22,02 & 39,38 & 0,34 & 0,03 & bd & 20,15 & 0,45 & 40,01 & 0,21 \\
\hline 148/96. & 181217 & 77,86 & 22,14 & 39,87 & $\mathrm{bd}$ & bd & 0,01 & 20,51 & 0,45 & 40,48 & 0,23 \\
\hline
\end{tabular}




\begin{tabular}{cccccccccccc} 
148/97. & 181217 & 78,37 & 21,63 & 39,75 & 0,17 & 0,03 & 0,02 & 19,78 & 0,46 & 40,17 & 0,24 \\
$148 / 98$. & 181217 & 78,06 & 21,94 & 39,32 & 0,47 & 0,01 & 0,05 & 20,00 & 0,39 & 39,92 & 0,27 \\
$148 / 99$. & 181217 & 78,55 & 21,45 & 39,51 & 0,18 & bd & 0,01 & 19,61 & 0,44 & 40,27 & 0,22 \\
$148 / 100$. & 181217 & 78,14 & 21,86 & 39,62 & bd & bd & 0,01 & 20,11 & 0,40 & 40,31 & 0,20 \\
148/101. & 181217 & 77,81 & 22,19 & 39,72 & 0,04 & 0,03 & 0,04 & 20,69 & 0,37 & 40,68 & 0,09 \\
$148 / 102$. & 181217 & 78,19 & 21,81 & 39,40 & 0,03 & 0,05 & 0,01 & 20,33 & 0,49 & 40,85 & 0,15 \\
$148 / 103$. & 181217 & 78,07 & 21,93 & 40,15 & 0,06 & 0,01 & 0,04 & 20,31 & 0,42 & 40,58 & 0,11 \\
$148 / 104$. & 181217 & 78,16 & 21,84 & 39,80 & 0,05 & 0,03 & bd & 20,18 & 0,35 & 40,49 & 0,14 \\
$148 / 105$. & 181217 & 78,05 & 21,95 & 39,83 & 0,01 & 0,03 & bd & 20,47 & 0,42 & 40,83 & 0,12 \\
$148 / 106$. & 181217 & 78,02 & 21,98 & 39,59 & 0,04 & 0,04 & 0,03 & 20,41 & 0,42 & 40,68 & 0,13 \\
\hline
\end{tabular}

High Al points in shocked olivine that is dark or striped in BSE. 'bd' =below detection limit. 


\begin{tabular}{cc}
\hline $\mathrm{Na}_{2} \mathrm{O}$ & Total \\
\hline & \\
bd & 101,64 \\
bd & 101,07 \\
bd & 100,53 \\
0,02 & 100,46 \\
bd & 100,30 \\
bd & 100,86 \\
bd & 100,49 \\
bd & 101,76 \\
0,01 & 100,67 \\
bd & 100,13 \\
bd & 101,94 \\
0,02 & 101,48 \\
0,01 & 100,77 \\
bd & 101,12 \\
bd & 100,72 \\
0,02 & 101,39 \\
0,02 & 100,61 \\
bd & 99,29 \\
bd & 99,72 \\
bd & 100,51 \\
bd & 99,72 \\
bd & 101,02 \\
bd & 100,33 \\
bd & 100,43 \\
bd & 100,18 \\
bd & 101,41 \\
bd & 100,85 \\
bd & 100,06 \\
0,01 & 100,48 \\
bd & 100,94 \\
0,03 & 100,06 \\
0,03 & 100,01 \\
bd & 99,04 \\
bd & 100,83 \\
bd & 100,71 \\
bd & 99,83 \\
0,03 & 100,46 \\
0,02 & 99,59 \\
bd & 100,94 \\
bd & 100,57 \\
0,02 & 100,55 \\
0,02 & 101,28 \\
bd & 100,08 \\
bd & 100,71 \\
0,01 & 100,78 \\
0,02 & 100,04 \\
bd & 100,25 \\
bd & 99,21 \\
0,03 & 100,39 \\
0,02 & 100,16 \\
0,01 & 99,62 \\
0,01 & 100,21 \\
0,01 & 99,68 \\
bd & 100,88 \\
bd & 100,30 \\
0,02 & 99,68
\end{tabular}




\begin{tabular}{|c|c|}
\hline bd & 99,59 \\
\hline 0,01 & 100,03 \\
\hline bd & 100,33 \\
\hline 0,02 & 101,69 \\
\hline bd & 100,98 \\
\hline $\mathrm{bd}$ & 100,36 \\
\hline 0,04 & 101,00 \\
\hline 0,01 & 98,39 \\
\hline bd & 99,48 \\
\hline$b d$ & 100,38 \\
\hline 0,01 & 100,40 \\
\hline bd & 99,12 \\
\hline 0,02 & 100,54 \\
\hline 0,03 & 99,91 \\
\hline bd & 101,13 \\
\hline bd & 100,76 \\
\hline bd & 100,65 \\
\hline 0,02 & 100,72 \\
\hline bd & 99,63 \\
\hline bd & 99,90 \\
\hline bd & 99,57 \\
\hline bd & 100,28 \\
\hline bd & 100,48 \\
\hline bd & 100,45 \\
\hline bd & 100,75 \\
\hline$b d$ & 100,48 \\
\hline 0,01 & 100,63 \\
\hline bd & 98,94 \\
\hline bd & 101,64 \\
\hline bd & 101,07 \\
\hline bd & 100,53 \\
\hline 0,02 & 100,46 \\
\hline bd & 100,30 \\
\hline bd & 100,86 \\
\hline bd & 100,49 \\
\hline bd & 101,76 \\
\hline 0,01 & 100,67 \\
\hline bd & 100,13 \\
\hline $\mathrm{bd}$ & 101,94 \\
\hline 0,02 & 101,48 \\
\hline 0,01 & 100,77 \\
\hline bd & 101,12 \\
\hline bd & 100,72 \\
\hline 0,02 & 101,39 \\
\hline 0,02 & 100,61 \\
\hline bd & 99,29 \\
\hline bd & 99,72 \\
\hline bd & 100,51 \\
\hline bd & 99,72 \\
\hline 0,01 & 99,96 \\
\hline 0,02 & 99,95 \\
\hline 0,02 & 99,97 \\
\hline 0,02 & 99,98 \\
\hline 0,02 & 99,97 \\
\hline bd & 100,76 \\
\hline 0,01 & 100,89 \\
\hline bd & 101,01 \\
\hline$b d$ & 101,41 \\
\hline
\end{tabular}




\begin{tabular}{cc} 
bd & 100,61 \\
bd & 100,67 \\
bd & 100,33 \\
bd & 98,8 \\
bd & 98,98 \\
bd & 98,33 \\
bd & 98,19 \\
bd & 100,34 \\
0,01 & 101,03 \\
bd & 100,09 \\
0,01 & 101,06 \\
bd & 101,67 \\
0,01 & 99,75 \\
0,01 & 101,07 \\
bd & 101,62 \\
0,01 & 101,61 \\
bd & 101,08 \\
bd & 101,41 \\
0,01 & 99,96 \\
0,02 & 99,97 \\
0,02 & 99,95 \\
0,02 & 99,98 \\
0,01 & 99,98 \\
0,02 & 99,98 \\
0,02 & 99,97 \\
& \\
0,04 & 101,65 \\
bd & 101,58 \\
0,03 & 101,72 \\
0,01 & 101,98 \\
0,04 & 100,14 \\
bd & 100,75 \\
0,03 & 101,51 \\
0,03 & 101,07 \\
0,05 & 101,44 \\
0,03 & 100,83 \\
bd & 100,60 \\
0,05 & 100,83 \\
0,03 & 101,59 \\
0,08 & 100,65 \\
0,06 & 98,40 \\
0,02 & 101,75 \\
0,02 & 98,00 \\
0,04 & 101,56 \\
0,02 & 101,37 \\
0,02 & 101,40 \\
0,01 & 101,23 \\
0,12 & 991,25 \\
0,09 & 99,70 \\
0,03 & 101,00 \\
0,03 & 100,85 \\
0,05 & 100,37 \\
0,10 & 99,82 \\
0,05 & 101,23 \\
0,06 & 100,55 \\
0,05 & 101,71 \\
\hline 0 & 101,47 \\
0.03
\end{tabular}




\begin{tabular}{|c|c|}
\hline & \\
\hline & \\
\hline & \\
\hline & \\
\hline & \\
\hline & \\
\hline 05 & 01,4 \\
\hline 02 & \\
\hline 06 & 00,6 \\
\hline 02 & 01,4 \\
\hline 06 & \\
\hline 05 & \\
\hline 04 & \\
\hline 07 & \\
\hline & \\
\hline 04 & \\
\hline 03 & \\
\hline 02 & \\
\hline 05 & \\
\hline 03 & \\
\hline 01 & \\
\hline 03 & \\
\hline 02 & \\
\hline 05 & 01 \\
\hline & \\
\hline 05 & \\
\hline 04 & \\
\hline 08 & \\
\hline 02 & 101 \\
\hline 02 & \\
\hline 02 & \\
\hline & \\
\hline & \\
\hline & \\
\hline & \\
\hline 03 & \\
\hline & \\
\hline 05 & \\
\hline 02 & \\
\hline 02 & \\
\hline 03 & \\
\hline & \\
\hline 04 & כ0 \\
\hline & \\
\hline & \\
\hline 05 & \\
\hline & \\
\hline 05 & 01, \\
\hline 03 & \\
\hline & \\
\hline & $\sigma_{1}$ \\
\hline & \\
\hline & \\
\hline & \\
\hline & \\
\hline & \\
\hline & \\
\hline & \\
\hline & \\
\hline
\end{tabular}




\begin{tabular}{|c|c|}
\hline 0,03 & 100,61 \\
\hline 0,02 & 100,83 \\
\hline 0,04 & 100,45 \\
\hline 0,02 & 101,28 \\
\hline 0,03 & 101,29 \\
\hline 0,04 & 100,71 \\
\hline 0,04 & 101,57 \\
\hline 0,01 & 99,94 \\
\hline 0,06 & 101,41 \\
\hline 0,07 & 98,31 \\
\hline 0,02 & 101,58 \\
\hline 0,02 & 101,08 \\
\hline 0,04 & 99,67 \\
\hline 0,04 & 101,19 \\
\hline 0,04 & 101,30 \\
\hline 0,03 & 100,78 \\
\hline 0,05 & 100,84 \\
\hline 0,02 & 100,40 \\
\hline 0,03 & 101,14 \\
\hline bd & 101,54 \\
\hline 0,05 & 101,44 \\
\hline 0,02 & 100,72 \\
\hline 0,01 & 101,14 \\
\hline 0,04 & 101,53 \\
\hline 0,03 & 101,63 \\
\hline 0,04 & 100,54 \\
\hline 0,03 & 101,46 \\
\hline 0,06 & 100,66 \\
\hline 0,02 & 101,08 \\
\hline bd & 100,60 \\
\hline 0,02 & 100,68 \\
\hline 0,04 & 101,53 \\
\hline bd & 101,09 \\
\hline 0,05 & 101,99 \\
\hline 0,02 & 98,76 \\
\hline 0,02 & 100,47 \\
\hline 0,03 & 101,26 \\
\hline 0,03 & 101,19 \\
\hline 0,01 & 101,59 \\
\hline 0,06 & 100,35 \\
\hline 0,04 & 101,32 \\
\hline 0,05 & 101,46 \\
\hline 0,01 & 101,34 \\
\hline 0,12 & 101,33 \\
\hline bd & 100,85 \\
\hline 0,08 & 98,16 \\
\hline 0,04 & 100,32 \\
\hline 0,04 & 101,44 \\
\hline 0,03 & 101,02 \\
\hline 0,01 & 100,68 \\
\hline 0,38 & 99,48 \\
\hline 0,06 & 102,12 \\
\hline 0,02 & 101,40 \\
\hline 0,01 & 101,65 \\
\hline 0,03 & 101,56 \\
\hline 0,05 & 100,73 \\
\hline 0,03 & 100,98 \\
\hline 0,06 & 101,30 \\
\hline 0,01 & 101,09 \\
\hline
\end{tabular}




\begin{tabular}{|c|c|}
\hline 0,05 & 100,60 \\
\hline 0,01 & 101,14 \\
\hline 0,02 & 101,42 \\
\hline 0,02 & 101,69 \\
\hline$b d$ & 101,20 \\
\hline 0,03 & 101,38 \\
\hline 0,19 & 101,66 \\
\hline 0,03 & 100,44 \\
\hline 0,04 & 101,71 \\
\hline 0,05 & 101,02 \\
\hline 0,03 & 101,50 \\
\hline 0,01 & 101,64 \\
\hline 0,03 & 100,91 \\
\hline 0,01 & 100,56 \\
\hline 0,03 & 102,02 \\
\hline bd & 101,68 \\
\hline 0,02 & 101,41 \\
\hline 0,04 & 101,07 \\
\hline 0,03 & 101,68 \\
\hline 0,01 & 101,45 \\
\hline 0,01 & 102,10 \\
\hline 0,01 & 102,21 \\
\hline bd & 102,58 \\
\hline 0,04 & 102,42 \\
\hline 0,05 & 101,89 \\
\hline bd & 101,99 \\
\hline 0,04 & 101,81 \\
\hline bd & 101,21 \\
\hline 0,03 & 101,55 \\
\hline 0,04 & 101,19 \\
\hline 0,10 & 100,38 \\
\hline 0,01 & 101,14 \\
\hline 0,03 & 101,48 \\
\hline 0,04 & 101,03 \\
\hline 0,02 & 101,24 \\
\hline 0,02 & 101,06 \\
\hline 0,03 & 100,52 \\
\hline 0,01 & 101,36 \\
\hline 0,05 & 100,31 \\
\hline 0,01 & 100,58 \\
\hline 0,06 & 101,74 \\
\hline 0,01 & 100,82 \\
\hline 0,03 & 98,19 \\
\hline 0,02 & 101,58 \\
\hline 0,02 & 101,16 \\
\hline 0,04 & 101,79 \\
\hline 0,03 & 102,31 \\
\hline bd & 102,31 \\
\hline 0,01 & 101,39 \\
\hline 0,02 & 102,00 \\
\hline 0,02 & 101,84 \\
\hline 0,01 & 101,45 \\
\hline 0,02 & 101,26 \\
\hline 0,01 & 101,55 \\
\hline 0,02 & 101,39 \\
\hline 0,03 & 100,41 \\
\hline 0,01 & 101,76 \\
\hline 0,03 & 101,45 \\
\hline 0,08 & 100,78 \\
\hline
\end{tabular}




$\begin{array}{cc}\text { 0,02 } & 102,05 \\ 0,01 & 101,98 \\ 0,05 & 101,50 \\ 0,07 & 101,48 \\ \text { bd } & 102,31 \\ 0,03 & 102,04 \\ 0,03 & 100,84 \\ 0,01 & 100,16 \\ 0,01 & 101,06 \\ 0,03 & 101,83 \\ 0,06 & 100,32 \\ 0,03 & 99,79 \\ 0,05 & 101,30 \\ \text { bd } & 101,23 \\ 0,03 & 101,24 \\ 0,03 & 100,94 \\ 0,03 & 101,72 \\ 0,01 & 101,85 \\ 0,04 & 101,92 \\ 0,05 & 101,40 \\ 0,06 & 101,16 \\ 0,04 & 98,53 \\ 0,01 & 100,03 \\ 0,03 & 101,98 \\ 0,02 & 101,12 \\ 0,02 & 101,72 \\ 0,03 & 101,12 \\ 0,05 & 100,11 \\ 0,04 & 100,61 \\ 0,04 & 101,08 \\ 0,05 & 101,80 \\ 0,01 & 101,68 \\ \text { bd } & 100,49 \\ 0,02 & 101,04 \\ 0,06 & 101,65 \\ \text { bd } & 100,36 \\ 0,05 & 100,46 \\ 0,02 & 102,19 \\ 0,01 & 101,53 \\ \text { bd } & 101,61 \\ 0,02 & 101,43 \\ 0,03 & 101,64 \\ 0,05 & 101,64 \\ 0,02 & 101,72 \\ \text { bd } & 100,62 \\ 0,06 & 99,66 \\ 0,02 & 100,85 \\ 0,10 & 100,00 \\ 0,04 & 99,96 \\ 0,04 & 100,18 \\ 0,12 & 100,24 \\ 0,04 & 101,88 \\ 0,03 & 101,57 \\ 0,04 & 101,94 \\ 0,01 & 101,59 \\ 0,01 & 101,86 \\ 0,05 & 101,77 \\ 0,02 & 100,61 \\ 0,05 & 101,60\end{array}$


$0,06 \quad 100,67$

$0,03 \quad 100,46$

$0,03 \quad 100,28$

$0,03 \quad 100,68$

$0,04 \quad 101,71$

$0,02 \quad 101,33$

$0,02 \quad 101,70$

$0,04 \quad 101,11$

$0,01 \quad 101,74$

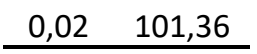


Supplementary Table Pyroxene Analyses.

\begin{tabular}{|c|c|c|c|c|c|c|c|c|c|c|c|c|c|c|}
\hline \multirow{2}{*}{\multicolumn{15}{|c|}{$\begin{array}{l}\text { Point } \\
\text { NWA } 8694 \text { Melt Inclusion }\end{array}$}} \\
\hline & & & & & & & & & & & & & & \\
\hline 10 & 121114 & 59,13 & 38,74 & 2,13 & 52,49 & 0,78 & 0,12 & 0,18 & 23,95 & 0,81 & 20,50 & 1,03 & 0,06 & 99,95 \\
\hline 11 & 121114 & 59,50 & 39,14 & 1,36 & 53,38 & 1,72 & $-0,05$ & 0,08 & 23,95 & 0,73 & 20,43 & 0,65 & 0,01 & 100,94 \\
\hline 72 & 100215 & 59,49 & 38,22 & 2,28 & 53,16 & 1,14 & 0,20 & 0,10 & 23,43 & 0,75 & 20,46 & 1,09 & 0,08 & 100,40 \\
\hline 74 & 121114 & 56,45 & 40,42 & 3,14 & 50,22 & 3,63 & 0,39 & 0,09 & 24,16 & 0,72 & 18,93 & 1,46 & 0,05 & 99,58 \\
\hline 74 & 100215 & 64,17 & 34,77 & 1,07 & 52,93 & 0,90 & 0,08 & 0,04 & 21,47 & 0,64 & 22,22 & 0,51 & 0,05 & 98,82 \\
\hline 76 & 121114 & 56,10 & 41,14 & 2,77 & 50,00 & 4,56 & 0,49 & 0,06 & 24,34 & 0,68 & 18,62 & 1,28 & 0,03 & 100,05 \\
\hline 77 & 121114 & 56,45 & 41,07 & 2,48 & 51,48 & 3,81 & 0,39 & 0,18 & 24,48 & 0,70 & 18,88 & 1,15 & 0,03 & 101,22 \\
\hline 81 & 100215 & 28,95 & 25,21 & 45,83 & 51,48 & 2,81 & 0,84 & 0,04 & 14,47 & 0,30 & 9,32 & 20,53 & 0,80 & 100,71 \\
\hline 104 & 100215 & 59,10 & 38,64 & 2,25 & 53,78 & 0,72 & 0,16 & 0,14 & 24,38 & 0,74 & 20,92 & 1,11 & 0,04 & 102,02 \\
\hline 107 & 100215 & 59,51 & 37,77 & 2,73 & 52,49 & 0,63 & 0,17 & 0,02 & 23,42 & 0,81 & 20,71 & 1,32 & 0,06 & 99,57 \\
\hline 108 & 100215 & 61,46 & 37,37 & 1,18 & 52,73 & 0,46 & 0,11 & 0,00 & 23,51 & 0,67 & 21,69 & 0,58 & 0,14 & 99,88 \\
\hline \multicolumn{15}{|c|}{ NWA 8694 Mesostasis } \\
\hline 122 & 100215 & 63,06 & 36,50 & 0,44 & 53,98 & 0,22 & $-0,01$ & 0,04 & 23,22 & 0,83 & 22,51 & 0,22 & $-0,02$ & 100,98 \\
\hline 125 & 100215 & 58,57 & 40,09 & 1,34 & 51,23 & 1,19 & 0,06 & 0,02 & 25,08 & 0,78 & 20,55 & 0,66 & 0,04 & 99,59 \\
\hline 50 & 121114 & 59,85 & 38,67 & 1,48 & 54,16 & 0,14 & $-0,01$ & 0,03 & 24,04 & 0,89 & 20,87 & 0,72 & $-0,02$ & 100,88 \\
\hline 56 & 121114 & 60,28 & 37,04 & 2,68 & 54,18 & 0,33 & 0,18 & 0,12 & 23,28 & 0,75 & 21,25 & 1,32 & 0,02 & 101,39 \\
\hline 51 & 121114 & 59,52 & 37,46 & 3,02 & 52,92 & 0,80 & 0,20 & 0,22 & 22,93 & 0,70 & 44 & 1,44 & 0,01 & 99,72 \\
\hline 80 & 121114 & 59,88 & 36,39 & 3,73 & 54,28 & 0,38 & 0,36 & 0,14 & 22,59 & 0,69 & 20,85 & 1,81 & 0,02 & 101,19 \\
\hline 43 & 121114 & 59,26 & 36,93 & 3,81 & 54,09 & 0,28 & 0,15 & 0,15 & 22,92 & 0,82 & 20,63 & 1,84 & 0,02 & 100,84 \\
\hline 83 & 114 & 59,74 & 36,13 & 4,13 & 53,96 & 0,49 & 0,21 & 0,23 & 22,57 & 0,73 & 20,93 & 2,01 & 0,03 & 101,23 \\
\hline 67 & 100215 & 56,64 & 38,93 & 4,43 & 53,32 & 0,35 & 0,28 & 0,16 & 24,02 & 0,81 & 19,60 & 2,13 & 0,04 & 100,62 \\
\hline 119 & 100215 & 58,93 & 36,55 & 4,52 & 53,75 & 0,42 & 0,22 & 0,16 & 23,10 & 87 & 20,89 & 2,23 & ,06 & 101,72 \\
\hline 99 & 100215 & 58,07 & 37,18 & 4,76 & 53,42 & 0,40 & 0,17 & 0,42 & 23,02 & 0,92 & 20,17 & 2,30 & 0,06 & 100 \\
\hline 68 & 100215 & 58,86 & 36,34 & 4,80 & 53,87 & 0,32 & 0,27 & 0,13 & 22,74 & 0,78 & 20,66 & 2,35 & 0,02 & 101,24 \\
\hline 70 & 100215 & 57,78 & 37,14 & 5,08 & 52,57 & 0,40 & 0,23 & 0,15 & 22,94 & 0,78 & 20,02 & 2,45 & 0,04 & 99,60 \\
\hline 44 & 121114 & 56,48 & 37,53 & 5,99 & 53,51 & 0,39 & 0,47 & 0,13 & 23,15 & 0,86 & 19 & 2,88 & 0,09 & 100,97 \\
\hline 112 & & & & 8,77 & & & & & 21,77 & & & 4,22 & 0,09 & \\
\hline 113 & 215 & 55,29 & 35,12 & 9,60 & 52,7 & 0,45 & 0,31 & 0,16 & 21,63 & 0,79 & 19,10 & 4,61 & 0,07 & 9,96 \\
\hline 101 & 100215 & 43,97 & 22,60 & 33,43 & 51,59 & 1,22 & 0,25 & 0,57 & 13,75 & 0,46 & 15,00 & 15,87 & 0,33 & 99,05 \\
\hline 116 & 100215 & 41,42 & 20,66 & 37,92 & 50,76 & 1,44 & 0,34 & 0,75 & 12,32 & 0,50 & 13,85 & 17,64 &, 31 & 97,98 \\
\hline 71 & 100215 & 41,86 & 17,13 & 41,01 & 52,74 & 0,46 & 0,33 & 0,31 & 10,51 & 0,44 & 14,41 & 19,64 &, 28 & 99,05 \\
\hline 82 & 121114 & 42,24 & 16,49 & 41,26 & 54,29 & 0,60 & 0,15 & 0,28 & & ,42 & 14,88 & 20,22 &, 27 & 101,46 \\
\hline 42 & 114 & 40,43 & 16,83 & 42,74 & 54,47 & 0,77 & 0,24 & 0,50 & 10,41 & 0,43 & 14,03 & 20,64 & 0,35 & 101,87 \\
\hline 53 & 121114 & 40,76 & 15,80 & 43,43 & 53,41 & 0,65 & 0,22 & 0,37 & 9,78 & 0,32 & 14,15 & 20,97 & 0,31 & 100,21 \\
\hline \multicolumn{15}{|c|}{ NWA 8694 Poikilitic } \\
\hline 66 & 121114 & 57,23 & 39,33 & 3,44 & 52,95 & 0,74 & 0,20 & 0,35 & 24,20 & 0,81 & 19,75 & 1,65 & 0,00 & 100,61 \\
\hline 68 & 121114 & 58,45 & 37,85 & 3,69 & 53,76 & 0,64 & 0,13 & 0,32 & 23,35 & 79 & 20,23 & 1,78 & 0,05 & 101,01 \\
\hline 27 & 121114 & 56,15 & 39,07 & 4,78 & 53,52 & 0,53 & 0,20 & 0,31 & 24,34 & 0,82 & 19,63 & 2,33 & 0,05 & 101,70 \\
\hline 35 & 121114 & 55,94 & 39,14 & 4,92 & 53,77 & 0,52 & 0,12 & 0,23 & 24,62 & 0,80 & 19,73 & 2,41 & 0,04 & 102,28 \\
\hline 29 & & & & 5,48 & & & & & & & & 2,65 & & \\
\hline 25 & & & 38,03 & 6,32 & 53,48 & 0,52 & 0,1 & 0,30 & 23,83 & 0,78 & 19,56 & 3,09 & ,06 & 101,75 \\
\hline 27 & 121114 & 55,95 & 37,66 & 6,39 & 53,66 & 0,58 & 0,1 & 0,29 & 23,44 & 0,77 & 19,54 & 3,10 & 0,05 & 101,54 \\
\hline 26 & 121114 & 54,69 & 36,93 & 8,39 & 53,36 & 0,56 & 0,21 & 0,35 & 23,22 & 0,69 & 19,29 & 4,12 & 0,06 & 101,84 \\
\hline 15 & 121114 & 54,71 & 35,29 & 10,01 & 52,89 & 0,69 & 0,19 & 0,39 & 21,86 & 0,69 & 19,01 & 4,84 & 0,09 & 100,68 \\
\hline 24 & 121114 & 47,42 & 25,91 & 26,66 & 53,87 & 1,09 & 0,24 & 0,73 & 15,85 & 0,52 & 16,27 & 12,73 & 0,29 & 101,55 \\
\hline 92 & 121114 & 43,89 & 24,52 & 31,59 & 53,11 & 1,13 & 0,29 & 0,58 & 15,00 & 0,53 & 15,06 & 15,08 & 0,29 & 101,00 \\
\hline 93 & 121114 & 43,69 & 24,19 & 32,11 & 53,28 & 1,05 & 0,26 & 0,67 & 14,78 & 0,55 & 14,98 & 15,31 & 0,30 & 101,13 \\
\hline 30 & 121114 & 43,00 & 22,26 & 34,74 & 53,56 & 1,02 & 0,22 & 0,61 & 13,43 & 0,51 & 14,56 & 16,36 & 0,25 & 100,56 \\
\hline 69 & 121114 & 41,46 & 22,04 & 36,50 & 52,37 & 1,31 & 0,31 & 0,75 & 13,33 & 0,47 & 14,07 & 17,23 & 0,31 & 100,37 \\
\hline 36 & 121114 & 41,24 & 21,23 & 37,53 & 52,85 & 1,87 & 0,40 & 0,68 & 12,83 & 0,51 & 13,99 & 17,71 & 0,33 & 101,20 \\
\hline 67 & 121114 & 40,67 & 15,74 & 43,59 & 53,83 & 1,01 & 0,23 & 0,40 & 9,74 & 0,36 & 14,11 & 21,05 & 0,34 & 101,06 \\
\hline $97 / 7$ & 121114 & 56,50 & 37,41 & 6,09 & 53,29 & 0,41 & 0,24 & 0,15 & 22,86 & 0,82 & 19,37 & 2,90 & 0,08 & 100,11 \\
\hline $97 / 8$ & & & 37,33 & 5,50 & & 0,38 & 0,29 & 0,13 & & 0,86 & & 2,61 & 0,06 & 100,09 \\
\hline $97 / 9$ & 121114 & 56,41 & 35,69 & 7,90 & 53,61 & 0,85 & 0,23 & 0,15 & 21,45 & 0,76 & 19,02 & 3,71 & 0,23 & 99,97 \\
\hline $97 / 10$ & 121114 & 54,49 & 36,14 & 9,37 & 52,71 & 4,43 & 0,21 & 0,13 & 19,17 & 0,63 & 16,21 & 3,88 & 1,34 & 98,90 \\
\hline $97 / 36$ & 121114 & 56,09 & 38,79 & 5,12 & 52,07 & 0,41 & 0,35 & 0,17 & 22,82 & 0,83 & 18,52 & 2,35 & 0,04 & 97,67 \\
\hline $97 / 37$ & 121114 & 55,49 & 38,61 & 5,90 & 52,50 & 0,43 & 0,34 & 0,17 & 22,74 & 0,80 & 18,34 & 2,72 & 0,06 & 98,14 \\
\hline $97 / 38$ & 121114 & 55,74 & 37,07 & 7,19 & 52,17 & 0,42 & 0,23 & 0,16 & 22,14 & 0,74 & 18,68 & 3,35 & 0,05 & 97,97 \\
\hline $97 / 39$ & 121114 & 56,03 & 36,91 & 7,05 & 52,91 & 0,35 & 0,37 & 0,11 & 22,27 & 0,78 & 18,97 & 3,32 & 0,07 & 99,24 \\
\hline $97 / 40$ & 121114 & 56,20 & 36,99 & 6,81 & 53,07 & 0,40 & 0,33 & 0,16 & 22,51 & 0,78 & 19,19 & 3,23 & 0,07 & 99,73 \\
\hline
\end{tabular}




\begin{tabular}{|c|c|c|c|c|c|c|c|c|c|c|c|c|c|c|}
\hline $97 / 41$ & 121114 & 56,82 & 37,51 & 5,67 & 53,03 & 0,43 & 0,42 & 0,13 & 22,66 & 0,80 & 19,26 & 2,67 & 0,07 & 99,46 \\
\hline $97 / 42$ & 121114 & 56,06 & 37,45 & 6,49 & 52,88 & 0,41 & 0,41 & 0,20 & 22,85 & 0,85 & 19,18 & 3,09 & 0,06 & 99,92 \\
\hline $97 / 43$ & 121114 & 55,78 & 37,08 & 7,13 & 53,04 & 0,42 & 0,41 & 0,20 & 22,83 & 0,81 & 19,26 & 3,43 & 0,07 & 100,47 \\
\hline $97 / 45$ & 121114 & 55,36 & 37,27 & 7,36 & 51,79 & 0,44 & 0,33 & 0,19 & 22,29 & 0,81 & 18,57 & 3,44 & 0,07 & 98,03 \\
\hline $97 / 46$ & 121114 & 54,53 & 37,72 & 7,75 & 52,45 & 0,43 & 0,31 & 0,21 & 22,16 & 0,77 & 17,97 & 3,56 & 0,10 & 98,20 \\
\hline $97 / 55$ & 21114 & 57,16 & 37,16 & 5,68 & 52,65 & 0,51 & 0,39 & 0,17 & 23,33 & 0,89 & 20,13 & 2,78 & 0,04 & 100,84 \\
\hline $97 / 58$ & 121114 & 54,48 & 39,65 & 5,86 & 52,13 & 0,72 & 0,29 & 0,19 & 22,59 & 0,79 & 17,41 & 2,61 & 0,17 & 97,02 \\
\hline $97 / 59$ & 121114 & 56,17 & 37,52 & 6,31 & 53,01 & 0,39 & 0,21 & 0,20 & 22,74 & 0,81 & 19,09 & 2,99 & 0,08 & 99,54 \\
\hline \multicolumn{15}{|c|}{ Chassigny Interstial-poikilitic } \\
\hline 60 & 191018 & 67,47 & 27,90 & 4,63 & 55,23 & 0,29 & 0,13 & 0,27 & 17,72 & 0,57 & 24,03 & 2,29 & 0,02 & 100,58 \\
\hline 61 & 91018 & 67,16 & 27,95 & 4,89 & 55,23 & 0,45 & 0,16 & 0,32 & 17,83 & 0,58 & 24,04 & 2,44 & 0,08 & 101,13 \\
\hline 63 & 191018 & 66,71 & 28,44 & 4,85 & 55,08 & 0,47 & 0,13 & 0,27 & 18,27 & 0,61 & 24,04 & 2,43 & 0,04 & 101,36 \\
\hline 65 & 191018 & 66,95 & 28,08 & 4,97 & 55,06 & 0,43 & 0,14 & 0,24 & 17,85 & 0,57 & 23,88 & 2,47 & 0,05 & 100,70 \\
\hline 66 & 191018 & 66,69 & 28,49 & 4,82 & 55,02 & 0,40 & 0,13 & 0,26 & 17,99 & 0,60 & 23,62 & 2,38 & 0,08 & 100,47 \\
\hline 67 & 191018 & 66,76 & 28,40 & 4,84 & 55,10 & 0,38 & 0,12 & 0,22 & 18,03 & 0,59 & 23,77 & 2,40 & 0,05 & 100,66 \\
\hline 48 & 191018 & 62,44 & 23,80 & 13,76 & 55,08 & 0,70 & 0,14 & 0,42 & 15,14 & 0,48 & 22,28 & 6,83 & 0,14 & 101,21 \\
\hline 50 & 191018 & 63,08 & 24,44 & 12,49 & 55,26 & 0,71 & 0,20 & 0,48 & 15,52 & 0,55 & 22,47 & 6,19 & 0,15 & 101,52 \\
\hline 57 & 191018 & 60,56 & 24,02 & 15,42 & 55,11 & 0,78 & 0,20 & 0,53 & 15,28 & 0,49 & 21,62 & 7,66 & 0,18 & 101,85 \\
\hline 68 & 191018 & 60,22 & 21,84 & 17,94 & 54,27 & 0,97 & 0,21 & 0,54 & 13,77 & 0,46 & 21,31 & 8,83 & 0,28 & 100,65 \\
\hline 52 & 191018 & 47,13 & 15,17 & 37,70 & 53,13 & 1,13 & 0,29 & 0,76 & 9,47 & 0,33 & 16,50 & 18,37 & 0,32 & 100,31 \\
\hline 53 & 191018 & 47,44 & 15,25 & 37,31 & 53,47 & 1,09 & 0,26 & 0,78 & 9,40 & 0,28 & 16,42 & 17,96 & 0,24 & 99,91 \\
\hline 54 & 191018 & 47,16 & 14,98 & 37,86 & 53,98 & 1,07 & 0,28 & 0,81 & 9,40 & 0,29 & 16,61 & 18,55 & 0,25 & 101,25 \\
\hline 55 & 191018 & 46,25 & 14,21 & 39,54 & 54,00 & 1,45 & 0,40 & 0,84 & 8,82 & 0,28 & 16,11 & 19,16 & 0,32 & 101,39 \\
\hline 56 & 191018 & 46,39 & 14,66 & 38,95 & 53,43 & 1,50 & 0,39 & 0,84 & 9,13 & 0,32 & 16,21 & 18,93 & 0,31 & 101,07 \\
\hline $59 / 1$ & 191018 & 46,69 & 14,67 & 38,64 & 53,69 & 1,31 & 0,31 & 0,83 & 9,09 & 0,32 & 16,23 & 18,69 & 0,34 & 100,80 \\
\hline $59 / 2$ & 191018 & 46,76 & 14,92 & 38,32 & 54,00 & 1,26 & 0,36 & 0,78 & 9,28 & 0,32 & 16,31 & 18,60 & 0,31 & 101,23 \\
\hline $59 / 3$ & 191018 & 46,38 & 14,70 & 38,92 & 54,83 & 1,24 & 0,32 & 0,83 & 9,25 & 0,29 & 16,37 & 19,12 & 0,31 & 102,57 \\
\hline $59 / 5$ & 191018 & 45,70 & 15,65 & 38,65 & 54,50 & 1,41 & 0,33 & 0,82 & 9,89 & 0,29 & 16,20 & 19,06 & 0,30 & 102,80 \\
\hline $59 / 6$ & 191018 & 46,45 & 14,93 & 38,62 & 54,21 & 1,30 & 0,30 & 0,79 & 9,26 & 0,30 & 16,16 & 18,69 & 0,28 & 101,29 \\
\hline $59 / 7$ & 191018 & 45,94 & 15,55 & 38,51 & 53,41 & 1,19 & 0,38 & 0,79 & 9,74 & 0,28 & 16,15 & 18,83 & 0,27 & 101,07 \\
\hline $59 / 8$ & 191018 & 46,72 & 15,20 & 38,09 & 53,70 & 1,28 & 0,33 & 0,80 & 9,50 & 0,32 & 16,38 & 18,58 & 0,31 & 101,18 \\
\hline $59 / 9$ & 191018 & 46,31 & 14,88 & 38,81 & 54,20 & 1,33 & 0,30 & 0,78 & 9,32 & 0,35 & 16,27 & 18,97 & 0,32 & 101,85 \\
\hline $59 / 10$ & 191018 & 46,06 & 14,98 & 38,96 & 53,52 & 1,29 & 0,33 & 0,80 & 9,42 & 0,32 & 16,24 & 19,11 & 0,29 & 101,32 \\
\hline $59 / 11$ & 191018 & 46,38 & 14,85 & 38,78 & 54,14 & 1,26 & 0,31 & 0,81 & 9,29 & 0,33 & 16,29 & 18,95 & 0,33 & 101,70 \\
\hline $59 / 12$ & 191018 & 46,91 & 14,66 & 38,42 & 53,77 & 1,25 & 0,30 & 0,78 & 9,21 & 0,36 & 16,52 & 18,83 & 0,27 & 101,28 \\
\hline $59 / 13$ & 191018 & 46,59 & 14,94 & 38,47 & 54,87 & 1,32 & 0,30 & 0,82 & 9,33 & 0,31 & 16,33 & 18,76 & 0,31 & 102,37 \\
\hline $59 / 14$ & 191018 & 47,12 & 14,73 & 38,15 & 53,47 & 1,33 & 0,33 & 0,79 & 9,17 & 0,30 & 16,46 & 18,54 & 0,34 & 100,73 \\
\hline $59 / 16$ & 191018 & 47,43 & 14,87 & 37,70 & 53,06 & 1,24 & 0,30 & 0,73 & 9,40 & 0,31 & 16,82 & 18,60 & 0,27 & 100,76 \\
\hline $59 / 19$ & 191018 & 46,34 & 15,54 & 38,12 & 53,92 & 1,19 & 0,34 & 0,79 & 9,81 & 0,32 & 16,41 & 18,78 & 0,31 & 101,90 \\
\hline $59 / 20$ & 191018 & 47,53 & 15,21 & 37,26 & 53,86 & 1,23 & 0,34 & 0,80 & 9,47 & 0,33 & 16,60 & 18,11 & 0,34 & 101,07 \\
\hline $59 / 21$ & 191018 & 47,10 & 15,45 & 37,44 & 54,13 & 1,27 & 0,32 & 0,73 & 9,64 & 0,30 & 16,49 & 18,24 & 0,28 & 101,42 \\
\hline $59 / 22$ & 191018 & 46,73 & 15,15 & 38,12 & 52,95 & 1,27 & 0,33 & 0,79 & 9,44 & 0,33 & 16,35 & 18,55 & 0,27 & 100,29 \\
\hline $59 / 23$ & 191018 & 47,13 & 15,13 & 37,74 & 53,97 & 1,22 & 0,28 & 0,79 & 9,48 & 0,33 & 16,56 & 18,45 & 0,33 & 101,41 \\
\hline $59 / 24$ & 191018 & 47,23 & 15,19 & 37,58 & 54,10 & 1,26 & 0,32 & 0,81 & 9,46 & 0,34 & 16,50 & 18,26 & 0,28 & 101,36 \\
\hline $59 / 25$ & 191018 & 47,06 & 15,86 & 37,07 & 53,79 & 1,25 & 0,30 & 0,72 & 9,96 & 0,32 & 16,58 & 18,17 & 0,28 & 101,39 \\
\hline $59 / 26$ & 191018 & 46,97 & 15,14 & 37,89 & 53,87 & 1,21 & 0,38 & 0,83 & 9,55 & 0,33 & 16,62 & 18,65 & 0,31 & 101,76 \\
\hline $59 / 27$ & 191018 & 46,39 & 15,45 & 38,16 & 53,89 & 1,29 & 0,29 & 0,79 & 9,62 & 0,33 & 16,20 & 18,54 & 0,30 & 101,26 \\
\hline $59 / 28$ & 191018 & 47,20 & 14,93 & 37,87 & 53,11 & 1,26 & 0,31 & 0,77 & 9,28 & 0,34 & 16,45 & 18,37 & 0,32 & 100,21 \\
\hline $59 / 29$ & 191018 & 46,71 & 15,54 & 37,75 & 53,95 & 1,24 & 0,29 & 0,82 & 9,73 & 0,31 & 16,41 & 18,46 & 0,26 & 101,48 \\
\hline $59 / 30$ & 191018 & 46,70 & 15,36 & 37,95 & 53,61 & 1,39 & 0,35 & 0,79 & 9,56 & 0,33 & 16,31 & 18,44 & 0,29 & 101,10 \\
\hline $59 / 31$ & 191018 & 46,11 & 15,60 & 38,29 & 52,65 & 1,35 & 0,34 & 0,78 & 9,45 & 0,34 & 15,68 & 18,12 & 0,34 & 99,06 \\
\hline $59 / 32$ & 191018 & 46,81 & 14,98 & 38,21 & 53,66 & 1,32 & 0,39 & 0,76 & 9,27 & 0,32 & 16,26 & 18,46 & 0,33 & 100,79 \\
\hline $59 / 33$ & 191018 & 47,15 & 15,23 & 37,63 & 52,94 & 1,45 & 0,31 & 0,84 & 9,52 & & 16,54 & 18,37 & 0,33 & 100,62 \\
\hline $59 / 34$ & 191018 & 46,54 & 15,75 & 37,71 & 53,37 & 1,37 & 0,36 & 0,79 & 9,67 & 0,31 & 16,03 & 18,07 & 0,34 & 100,33 \\
\hline \multicolumn{15}{|c|}{ NWA 2737 interstial-poikilitic } \\
\hline 137 & 181217 & 77,66 & 19,57 & 2,77 & 56,22 & 0,64 & 0,47 & 0,25 & 12,95 & 0,33 & 28,85 & 1,44 & 0,09 & 101,26 \\
\hline 141 & 181217 & 78,40 & 18,62 & 2,98 & 56,43 & 0,38 & 0,40 & 0,19 & 12,29 & 0,42 & 29,01 & 1,53 & 0,04 & 100,82 \\
\hline 51 & 181217 & 71,16 & 17,82 & 11,02 & 55,82 & 0,51 & 0,15 & 0,47 & 11,63 & 0,39 & 26,05 & 5,60 & 0,18 & 101,03 \\
\hline 55 & 181217 & 72,94 & 18,77 & 8,30 & 55,76 & 0,47 & 0,11 & 0,34 & 12,52 & 0,41 & 27,31 & 4,31 & 0,15 & 101,38 \\
\hline 58 & 181217 & 70,01 & 17,02 & 12,97 & 55,86 & 0,60 & 0,11 & 0,68 & 11,01 & 0,41 & 25,38 & 6,53 & 0,25 & 100,84 \\
\hline 60 & 181217 & 75,37 & 18,06 & 6,57 & 56,70 & 0,38 & 0,10 & 0,36 & 11,96 & 0,45 & 27,98 & 3,39 & 0,13 & 101,44 \\
\hline 63 & 181217 & 74,73 & 19,14 & 6,13 & 56,19 & 0,62 & 0,08 & 0,36 & 12,71 & 0,46 & 27,81 & 3,17 & 0,07 & 101,51 \\
\hline 79 & 181217 & 74,00 & 19,54 & 6,46 & 55,24 & 0,45 & 0,14 & 0,35 & 12,94 & 0,41 & 27,53 & 3,34 & 0,11 & 100,59 \\
\hline
\end{tabular}




\begin{tabular}{|c|c|c|c|c|c|c|c|c|c|c|c|c|c|c|}
\hline 80 & 181217 & 4,10 & 19,80 & & 55,16 & 0,43 & 0,10 & 0,33 & 12,98 & 0,54 & 27,26 & 3,13 & 0,13 & 100,29 \\
\hline $81 / 59$ & 181217 & 75,18 & 19,63 & 5,18 & 54,79 & 1,41 & 0,16 & 0,46 & 12,39 & 0,35 & 26,64 & 2,56 & 0,15 & 98,92 \\
\hline $99 / 46$ & 181217 & 76,75 & 17,31 & 5,94 & 5,67 & 0,41 & 0,14 & 0,77 & 11,49 & 0,35 & 28,60 & 3,09 & 0,09 & 100,61 \\
\hline $99 / 47$ & 181217 & 76,60 & 18,01 & 5,39 & 54,55 & 0,78 & 0,18 & 0,69 & 11,79 & 0,40 & 28,09 & 2,75 & 0,11 & 99,36 \\
\hline $99 / 48$ & 181217 & 71,79 & 16,80 & 11,41 & 5,18 & 0,54 & 0,16 & 0,65 & 11,07 & 0,42 & 26,50 & 5,84 & 0,20 & 100,57 \\
\hline $99 / 49$ & 181217 & 75,27 & 18,72 & 6,02 & 55,40 & 0,50 & 0,12 & 0,55 & 12,45 & 0,41 & 28,07 & 3,12 & 0,10 & 100,72 \\
\hline $99 / 50$ & 181217 & 75,15 & 18,19 & 6,66 & 55,34 & 0,44 & 0,13 & 0,54 & 11,96 & 0,37 & 27,73 & 3,41 & 0,10 & 100,02 \\
\hline $99 / 51$ & 181217 & 75,66 & 18,74 & 5,60 & 54,43 & 1,16 & 0,10 & 0,47 & 12,23 & 0,38 & 27,70 & 2,86 & 0,04 & 99,40 \\
\hline 75 & 181217 & 50,92 & 10,74 & 38,34 & 3,75 & 1,01 & 0,21 & 0,84 & 6,86 & 0,26 & 18,26 & 19,14 & 0,35 & 100,69 \\
\hline 76 & 181217 & 51,17 & 11,17 & 37,66 & 4,36 & 1,01 & 0,35 & 0,91 & 7,13 & 0,31 & 18,29 & 18,73 & 0,35 & 101,45 \\
\hline $145 / 19$ & 181217 & 51,13 & 11,05 & 37,82 & 54,61 & 1,00 & 0,31 & 0,90 & 6,97 & 0,26 & 18,10 & 18,64 & 0,38 & 101,17 \\
\hline $145 / 20$ & 181217 & 52,38 & 12,11 & 35,51 & 4,80 & 1,08 & 0,21 & 0,85 & 7,71 & 0,30 & 18,66 & 17,61 & 0,33 & 101,55 \\
\hline $145 / 21$ & 181217 & 50,79 & 11,29 & 37,92 & 54,65 & 1,05 & 0,23 & 0,93 & 7,08 & 0,25 & 17,90 & 18,59 & 0,33 & 101,03 \\
\hline $145 / 23$ & 181217 & 49,22 & 10,16 & 40,62 & 2,56 & 1,04 & 0,25 & 0,89 & 6,27 & 0,27 & 17,08 & 19,61 & 0,34 & 98,30 \\
\hline $145 / 25$ & 181217 & 50,73 & 10,70 & 38,58 & 54,49 & 1,03 & 0,30 & 1,00 & 6,83 & 0,21 & 18,18 & 19,24 & 0,33 & 101,63 \\
\hline $145 / 26$ & 1812 & 51,36 & 10,25 & 38,39 & 4,19 & 0,99 & 0,23 & 0,98 & 6,42 & 0,20 & 18,04 & 18,77 & 0,31 & 100,17 \\
\hline $145 / 28$ & 181217 & 53,13 & 1,77 & 35,10 & 4,75 & 0,98 & 0,28 & 0,90 & 7,48 & 0,22 & 8,99 & 17,45 & 0,32 & 101,37 \\
\hline $145 / 29$ & 181217 & 50,41 & 10,68 & 38,90 & 54,33 & 0,98 & 0,26 & 0,97 & 6,80 & 0,30 & 18,00 & 19,32 & 0,29 & 101,26 \\
\hline $145 / 30$ & 181217 & 55,60 & 12,82 & 31,58 & 54,96 & 0,98 & 0,28 & 0,76 & 8,16 & 0,23 & 19,85 & 15,70 & 0,27 & 101,19 \\
\hline $145 / 31$ & 181217 & 50,10 & 10,47 & 39,42 & 54,63 & 0,98 & 0,31 & 0,95 & 6,61 & 0,20 & 17,74 & 19,41 & 0,35 & 101,21 \\
\hline $145 / 32$ & 181217 & 49,58 & 10,52 & 39,90 & 54,70 & 0,96 & 0,25 & 1,01 & 6,66 & 0,36 & 17,57 & 19,68 & 0,29 & 101,48 \\
\hline $145 / 33$ & 181217 & 50,81 & 10,55 & 38,64 & 54,20 & 0,97 & 0,28 & 0,96 & 6,63 & 0,30 & 17,92 & 18,97 & 0,28 & 100,55 \\
\hline $145 / 34$ & 181217 & 55,96 & 13,32 & 30,72 & 54,98 & 0,97 & 0,27 & 0,83 & 8,46 & 0,29 & 19,91 & 15,21 & 0,19 & 101,10 \\
\hline $145 / 35$ & 181217 & 52,91 & 12,11 & 34,98 & 53,80 & 1,16 & 0,24 & 0,80 & 7,65 & 0,40 & 18,72 & 17,22 & 0,27 & 100,30 \\
\hline $145 / 36$ & 181217 & 51,29 & 10,45 & 38,26 & 54,46 & 1,40 & 0,26 & 0,95 & 6,54 & 0,27 & 18,02 & 18,69 & 0,34 & 100,97 \\
\hline $145 / 41$ & 181217 & 53,00 & 11,89 & 35,11 & 54,51 & 1,00 & 0,32 & 0,88 & 7,65 & 0,25 & 19,10 & 17,61 & 0,35 & 101,67 \\
\hline $145 / 42$ & 181217 & 49,55 & 9,93 & 40,52 & 54,70 & 1,04 & 0,29 & 0,96 & 6,18 & 0,25 & 17,33 & 19,72 & 0,36 & 100,82 \\
\hline $145 / 43$ & 181217 & 50,55 & 9,65 & 39,80 & 54,35 & 1,05 & 0,30 & 1,02 & 6,04 & 0,24 & 17,78 & 19,48 & 0,34 & 100,60 \\
\hline $145 / 44$ & 181217 & 50,34 & 10,88 & 38,79 & 54,35 & 1,11 & 0,28 & 0,96 & 6,97 & 0,18 & 18,07 & 19,37 & 0,35 & 101,63 \\
\hline $145 / 45$ & 181217 & 52,07 & 11,04 & 36,89 & 54,25 & 0,92 & 0,26 & 0,90 & 6,90 & 0,27 & 18,27 & 18,02 & 0,32 & 100,11 \\
\hline $145 / 46$ & 181217 & 51,90 & 10,95 & 37,14 & 54,58 & 1,03 & 0,29 & 0,97 & 6,96 & 0,26 & 18,47 & 18,40 & 0,32 & 101,30 \\
\hline $145 / 47$ & 181217 & 49,63 & 10,03 & 40,33 & 54,30 & 1,11 & 0,34 & 1,01 & 6,34 & 0,28 & 17,60 & 19,91 & 0,36 & 101,25 \\
\hline $145 / 48$ & 181217 & 51,64 & 10,90 & 37,45 & 54,45 & 1,02 & 0,29 & 0,96 & 6,88 & 0,23 & 18,31 & 18,48 & 0,29 & 100,90 \\
\hline $145 / 49$ & 181217 & 49,50 & 10,07 & 40,43 & 53,82 & 1,04 & 0,30 & 0,98 & 6,32 & 0,20 & 17,40 & 19,77 & 0,37 & 100,23 \\
\hline $145 / 51$ & 181217 & 50,31 & 9,99 & 39,70 & 54,38 & 1,04 & 0,31 & 0,94 & 6,34 & 0,27 & 17,91 & 19,68 & 0,31 & 101,17 \\
\hline $145 / 52$ & 181217 & 52,43 & 11,46 & 36,11 & 54,56 & 0,95 & 0,27 & 0,89 & 7,23 & 0,26 & 18,52 & 17,74 & 0,32 & 100,77 \\
\hline $145 / 53$ & 181217 & 51,52 & 10,53 & 37,95 & 53,88 & 1,03 & 0,31 & 0,92 & 6,74 & 0,25 & 18,44 & 18,91 & 0,39 & 100,87 \\
\hline $145 / 55$ & 181217 & 50,60 & 10,39 & 39,01 & 54,21 & 1,03 & 0,29 & 0,96 & 6,60 & 0,21 & 18,01 & 19,33 & 0,32 & 100,97 \\
\hline $145 / 56$ & 181217 & 51,65 & 11,07 & 37,28 & 54,25 & 0,95 & 0,26 & 0,91 & 7,05 & 0,24 & 18,51 & 18,59 & 0,32 & 101,09 \\
\hline $145 / 57$ & 181217 & 50,65 & 9,93 & 39,41 & 54,24 & 1,11 & 0,26 & 0,90 & 6,23 & 0,21 & 17,86 & 19,34 & 0,36 & 100,51 \\
\hline $145 / 58$ & 181217 & 52,32 & 11,78 & 35,90 & 54,38 & 1,06 & 0,28 & 0,88 & 7,46 & 0,33 & 18,61 & 17,78 & 0,33 & 101,14 \\
\hline $145 / 59$ & 181217 & 50,94 & 10,02 & 39,03 & 53,36 & 1,58 & 0,26 & 0,89 & 6,20 & 0,26 & 17,71 & 18,90 & 0,30 & 99,45 \\
\hline $145 / 60$ & 181217 & 52,95 & 11,63 & 35,42 & 53,81 & 1,31 & 0,28 & 0,91 & 7,33 & 0,30 & 18,69 & 17,38 & 0,34 & 100,37 \\
\hline $145 / 62$ & 181217 & 50,94 & 10,48 & 38,58 & 53,88 & 1,47 & 0,30 & 0,94 & 6,64 & 0,29 & 18,09 & 19,08 & 0,38 & 101,12 \\
\hline
\end{tabular}




\begin{tabular}{|c|c|c|c|c|c|c|c|c|}
\hline \multirow{2}{*}{$\frac{\text { Point }}{\text { NWA } 8694}$} & Sesssion & Spin & Chrom & Usp & Mgt & SiO2 & Al2O3 & TiO2 \\
\hline & & & & & & & & \\
\hline 18 & 121114 & 12,46 & 75,33 & 4,52 & 7,26 & 0,12 & 5,82 & 1,65 \\
\hline 19 & 121114 & 11,96 & 75,94 & 4,54 & 7,32 & 0,07 & 5,59 & 1,66 \\
\hline 16 & 161219 & 13,00 & 72,93 & 5,41 & 8,19 & 0,13 & 6,12 & 1,99 \\
\hline 17 & 161219 & 13,16 & 73,43 & 5,70 & 7,44 & 0,08 & 6,17 & 2,09 \\
\hline 25 & 161219 & 14,55 & 72,72 & 5,82 & 6,62 & 0,08 & 6,91 & 2,16 \\
\hline 24 & 161219 & 14,50 & 70,78 & 7,30 & 7,19 & 0,06 & 6,92 & 2,73 \\
\hline 46 & 161219 & 15,14 & 68,62 & 7,91 & 8,55 & $-0,06$ & 7,16 & 2,93 \\
\hline 23 & 161219 & 14,75 & 69,65 & 8,26 & 6,84 & 0,14 & 7,14 & 3,13 \\
\hline 28 & 161219 & 15,07 & 67,06 & 8,52 & 8,94 & 0,11 & 7,19 & 3,18 \\
\hline 26 & 161219 & 17,22 & 65,01 & 8,78 & 9,00 & 0,00 & 8,20 & 3,28 \\
\hline 17 & 121114 & 14,69 & 67,88 & 8,94 & 8,21 & 0,08 & 6,91 & 3,29 \\
\hline 45 & 161219 & 18,08 & 63,66 & 9,33 & 8,36 & 0,16 & 8,57 & 3,47 \\
\hline 100 & 110215 & 16,39 & 63,87 & 10,12 & 9,31 & 0,09 & 7,74 & 3,75 \\
\hline 40 & 161219 & 16,25 & 64,20 & 10,41 & 8,51 & 0,17 & 7,66 & 3,84 \\
\hline 43 & 161219 & 17,66 & 61,27 & 10,69 & 10,30 & 0,02 & 8,47 & 4,02 \\
\hline 41 & 161219 & 16,55 & 60,20 & 11,03 & 10,28 & 0,54 & 7,87 & 4,11 \\
\hline 28 & 121114 & 20,75 & 58,16 & 11,52 & 9,06 & 0,14 & 9,83 & 4,28 \\
\hline 42 & 161219 & 16,96 & 61,88 & 11,88 & 8,81 & 0,13 & 8,08 & 4,43 \\
\hline 27 & 161219 & 14,77 & 63,73 & 12,10 & 8,98 & 0,11 & 7,00 & 4,50 \\
\hline 86 & 121114 & 16,80 & 59,72 & 12,46 & 10,82 & 0,06 & 7,85 & 4,56 \\
\hline 19 & 161219 & 17,47 & 61,05 & 12,48 & 8,77 & 0,07 & 8,39 & 4,70 \\
\hline 37 & 161219 & 18,52 & 59,25 & 12,74 & 9,26 & 0,07 & 8,86 & 4,77 \\
\hline 22 & 161219 & 15,29 & 60,74 & 12,95 & 10,55 & 0,13 & 7,20 & 4,78 \\
\hline 38 & 161219 & 15,66 & 60,67 & 13,17 & 10,18 & 0,09 & 7,37 & 4,85 \\
\hline 21 & 161219 & 16,32 & 59,17 & 13,20 & 11,12 & 0,06 & 7,80 & 4,94 \\
\hline 44 & 161219 & 16,71 & 58,02 & 13,86 & 11,33 & 0,02 & 7,93 & 5,15 \\
\hline 20 & 161219 & 15,80 & 59,59 & 14,37 & 10,02 & 0,06 & 7,56 & 5,39 \\
\hline 29 & 161219 & 13,86 & 58,40 & 16,71 & 11,26 & bd & 6,47 & 6,12 \\
\hline 30 & 161219 & 12,53 & 57,27 & 18,35 & 11,74 & $b d$ & 5,85 & 6,71 \\
\hline 39 & 161219 & 11,08 & 58,41 & 19,54 & 11,06 & bd & 5,12 & 7,08 \\
\hline \multicolumn{9}{|c|}{ Chassigny } \\
\hline 12 & 200913 & 17,11 & 71,77 & 5,75 & 5,21 & 0,04 & 8,14 & 2,14 \\
\hline 9 & 200913 & 19,22 & 67,65 & 6,74 & 6,24 & 0,05 & 9,29 & 2,55 \\
\hline 7 & 200913 & 21,02 & 63,40 & 9,22 & 6,19 & 0,05 & 10,16 & 3,49 \\
\hline 10 & 200913 & 20,17 & 67,23 & 6,84 & 5,56 & 0,06 & 9,74 & 2,59 \\
\hline 6 & 200913 & 12,74 & 77,48 & 3,53 & 5,98 & 0,08 & 6,10 & 1,32 \\
\hline 23 & 111213 & 12,75 & 77,48 & 3,71 & 5,48 & 0,16 & 6,02 & 1,37 \\
\hline \multicolumn{9}{|c|}{ NWA 2737} \\
\hline 52 & 2737 & 15,01 & 74,83 & 4,17 & 5,44 & 0,09 & 7,44 & 1,61 \\
\hline 53 & 2737 & 13,16 & 78,80 & 3,13 & 4,07 & 0,11 & 6,49 & 1,21 \\
\hline 57 & 2737 & 14,57 & 75,09 & 3,88 & 6,05 & 0,05 & 7,17 & 1,48 \\
\hline 62 & 2737 & 12,97 & 78,63 & 3,13 & 4,85 & 0,07 & 6,39 & 1,20 \\
\hline 65 & 2737 & 20,73 & 69,72 & 3,54 & 5,45 & 0,07 & 10,27 & 1,38 \\
\hline 70 & 2737 & 13,15 & 79,09 & 3,06 & 4,57 & 0,03 & 6,45 & 1,18 \\
\hline 71 & 2737 & 15,41 & 62,01 & 13,67 & 8,64 & 0,04 & 7,40 & 5,14 \\
\hline 73 & 2737 & 16,32 & 74,28 & 4,48 & 4,91 & 0,46 & 8,03 & 1,73 \\
\hline
\end{tabular}




\begin{tabular}{|c|c|c|c|c|c|c|c|c|}
\hline 78 & 2737 & 20,29 & 69,46 & 4,17 & 5,66 & 0,05 & 9,87 & 1,58 \\
\hline $81 / 41$ & 2737 & 19,04 & 68,79 & 5,00 & 6,89 & 0,05 & 9,49 & 1,95 \\
\hline $81 / 42$ & 2737 & 17,53 & 71,53 & 4,58 & 6,09 & 0,04 & 8,70 & 1,79 \\
\hline $81 / 43$ & 2737 & 16,02 & 74,10 & 4,10 & 5,50 & 0,05 & 7,91 & 1,59 \\
\hline $81 / 44$ & 2737 & 14,95 & 76,34 & 3,82 & 4,75 & 0,01 & 7,30 & 1,46 \\
\hline $81 / 45$ & 2737 & 14,79 & 77,07 & 3,55 & 4,59 & 0,01 & 7,20 & 1,36 \\
\hline $81 / 46$ & 2737 & 14,30 & 77,64 & 3,83 & 3,95 & 0,04 & 7,00 & 1,46 \\
\hline $81 / 47$ & 2737 & 13,99 & 77,05 & 3,61 & 5,07 & 0,04 & 6,90 & 1,38 \\
\hline $81 / 48$ & 2737 & 13,59 & 78,22 & 3,41 & 4,37 & 0,05 & 6,63 & 1,30 \\
\hline $81 / 49$ & 2737 & 13,25 & 77,86 & 3,40 & 5,48 & $-0,01$ & 6,52 & 1,30 \\
\hline $81 / 50$ & 2737 & 13,57 & 78,06 & 3,34 & 4,62 & 0,06 & 6,62 & 1,29 \\
\hline $81 / 51$ & 2737 & 13,57 & 77,76 & 3,40 & 5,26 & 0,01 & 6,65 & 1,31 \\
\hline $81 / 52$ & 2737 & 13,48 & 77,99 & 3,54 & 4,98 & $-0,01$ & 6,63 & 1,36 \\
\hline $81 / 53$ & 2737 & 13,88 & 78,15 & 3,34 & 4,49 & 0,01 & 6,76 & 1,27 \\
\hline $81 / 54$ & 2737 & 13,88 & 77,45 & 3,48 & 4,49 & 0,10 & 6,83 & 1,35 \\
\hline $81 / 55$ & 2737 & 14,35 & 76,82 & 3,75 & 4,52 & 0,07 & 7,01 & 1,44 \\
\hline $81 / 56$ & 2737 & 15,21 & 74,41 & 4,10 & 6,01 & 0,03 & 7,51 & 1,59 \\
\hline $81 / 57$ & 2737 & 16,26 & 72,24 & 4,51 & 6,44 & 0,08 & 8,03 & 1,73 \\
\hline $81 / 98$ & 2737 & 21,08 & 67,99 & 5,14 & 5,52 & 0,04 & 10,30 & 1,98 \\
\hline $81 / 99$ & 2737 & 20,95 & 67,70 & 4,72 & 5,79 & 0,12 & 10,32 & 1,83 \\
\hline $98 / 1$ & 2737 & 23,66 & 62,20 & 6,23 & 7,77 & 0,01 & 11,82 & 2,44 \\
\hline 99/11 & 2737 & 18,13 & 70,27 & 3,88 & 7,16 & 0,09 & 8,93 & 1,51 \\
\hline 99/12 & 2737 & 17,46 & 71,86 & 4,24 & 5,75 & 0,10 & 8,58 & 1,62 \\
\hline $99 / 13$ & 2737 & 16,72 & 72,57 & 4,09 & 6,34 & 0,04 & 8,28 & 1,57 \\
\hline $99 / 14$ & 2737 & 16,16 & 73,01 & 4,09 & 6,46 & 0,04 & 8,01 & 1,58 \\
\hline $99 / 15$ & 2737 & 16,23 & 73,40 & 4,09 & 6,14 & 0,02 & 8,01 & 1,58 \\
\hline $99 / 16$ & 2737 & 15,73 & 74,48 & 3,89 & 5,49 & 0,05 & 7,68 & 1,49 \\
\hline 99/17 & 2737 & 15,67 & 74,13 & 4,10 & 5,82 & 0,05 & 7,70 & 1,58 \\
\hline $99 / 18$ & 2737 & 15,34 & 73,66 & 3,68 & 6,34 & 0,15 & 7,40 & 1,40 \\
\hline 99/19 & 2737 & 17,35 & 70,72 & 3,53 & 0,05 & 1,15 & 8,10 & 1,29 \\
\hline $99 / 20$ & 2737 & 15,28 & 75,42 & 3,75 & 5,27 & 0,04 & 7,53 & 1,46 \\
\hline $99 / 21$ & 2737 & 14,93 & 75,68 & 3,68 & 5,29 & 0,05 & 7,37 & 1,42 \\
\hline $99 / 22$ & 2737 & 14,52 & 76,04 & 3,61 & 5,82 & 0,01 & 7,17 & 1,41 \\
\hline $99 / 23$ & 2737 & 14,06 & 75,99 & 3,75 & 5,92 & 0,04 & 6,90 & 1,43 \\
\hline $99 / 24$ & 2737 & 14,65 & 76,25 & 3,68 & 5,28 & 0,03 & 7,20 & 1,41 \\
\hline $99 / 25$ & 2737 & 14,41 & 76,09 & 3,68 & 5,67 & 0,01 & 7,13 & 1,42 \\
\hline $99 / 26$ & 2737 & 14,11 & 76,60 & 3,75 & 5,54 & 0,00 & 6,89 & 1,44 \\
\hline $99 / 27$ & 2737 & 14,43 & 76,72 & 3,48 & 5,10 & 0,04 & 7,09 & 1,34 \\
\hline $99 / 28$ & 2737 & 14,02 & 76,37 & 3,54 & 5,65 & 0,05 & 6,92 & 1,36 \\
\hline $99 / 29$ & 2737 & 13,95 & 76,44 & 3,40 & 6,07 & 0,01 & 6,89 & 1,30 \\
\hline $99 / 30$ & 2737 & 14,13 & 77,00 & 3,62 & 4,70 & 0,08 & 7,02 & 1,42 \\
\hline $99 / 31$ & 2737 & 13,57 & 77,17 & 3,47 & 5,37 & 0,05 & 6,63 & 1,32 \\
\hline $99 / 32$ & 2737 & 14,00 & 76,74 & 3,54 & 5,44 & 0,05 & 6,91 & 1,38 \\
\hline $99 / 33$ & 2737 & 13,74 & 76,65 & 3,40 & 5,79 & 0,06 & 6,75 & 1,31 \\
\hline $99 / 34$ & 2737 & 13,54 & 76,48 & 3,61 & 5,81 & 0,07 & 6,66 & 1,38 \\
\hline 99/35 & 2737 & 14,19 & 76,06 & 3,48 & 6,27 & 0,18 & 6,96 & 1,34 \\
\hline $99 / 36$ & 2737 & 14,16 & 76,15 & 3,47 & 6,09 & 0,02 & 6,97 & 1,34 \\
\hline 99/37 & 2737 & 13,75 & 76,48 & 3,61 & 5,88 & 0,05 & 6,73 & 1,37 \\
\hline $99 / 38$ & 2737 & 14,06 & 75,92 & 3,47 & 6,13 & 0,07 & 6,89 & 1,34 \\
\hline 99/39 & 2737 & 13,72 & 76,04 & 3,81 & 6,43 & $-0,01$ & 6,74 & 1,46 \\
\hline
\end{tabular}




$\begin{array}{crrrrrrrr}99 / 40 & 2737 & 14,64 & 75,10 & 3,75 & 6,51 & 0,00 & 7,25 & 1,45 \\ 99 / 41 & 2737 & 14,50 & 75,68 & 3,96 & 5,59 & 0,04 & 7,13 & 1,52 \\ 99 / 42 & 2737 & 14,98 & 74,12 & 4,02 & 6,60 & 0,03 & 7,40 & 1,57 \\ 99 / 43 & 2737 & 15,36 & 73,01 & 4,02 & 7,47 & 0,02 & 7,60 & 1,56 \\ 99 / 44 & 2737 & 15,08 & 72,92 & 4,23 & 7,49 & 0,05 & 7,34 & 1,61 \\ 144 & 2737 & 20,81 & 68,00 & 5,39 & 5,66 & 0,01 & 10,44 & 2,12 \\ 146 & 2737 & 16,24 & 75,75 & 4,39 & 3,06 & 0,07 & 8,01 & 1,69 \\ 147 & 2737 & 15,52 & 76,24 & 3,97 & 4,14 & 0,03 & 7,73 & 1,56\end{array}$




\begin{tabular}{|c|c|c|c|c|c|}
\hline Cr2O3 & $\mathrm{FeO}$ & $\mathrm{Fe} 2 \mathrm{O3}$ & $\mathrm{MnO}$ & $\mathrm{MgO}$ & Total \\
\hline 52,46 & 35,19 & 1,07 & nd & 2,33 & 98,63 \\
\hline 52,93 & 34,98 & 1,06 & nd & 2,45 & 98,74 \\
\hline 51,14 & 30,00 & 6,04 & 0,42 & 2,62 & 98,45 \\
\hline 51,31 & 30,15 & 5,46 & 0,37 & 2,51 & 98,14 \\
\hline 51,46 & 31,00 & 4,92 & 0,36 & 2,32 & 99,21 \\
\hline 50,37 & 31,65 & 5,38 & 0,44 & 2,28 & 99,84 \\
\hline 48,33 & 31,46 & 6,33 & 0,26 & 2,32 & 98,72 \\
\hline 50,27 & 32,77 & 5,19 & 0,44 & 2,18 & 101,27 \\
\hline 47,68 & 32,55 & 6,68 & 0,36 & 2,07 & 99,82 \\
\hline 46,15 & 32,20 & 6,72 & 0,36 & 2,21 & 99,11 \\
\hline 47,59 & 37,09 & 1,12 & nd & 2,55 & 98,63 \\
\hline 44,98 & 31,92 & 6,21 & 0,42 & 2,44 & 98,17 \\
\hline 44,98 & 38,57 & 1,16 & nd & 2,47 & 98,75 \\
\hline 45,10 & 32,75 & 6,28 & 0,39 & 2,09 & 98,29 \\
\hline 43,80 & 32,35 & 7,73 & 0,45 & 2,59 & 99,43 \\
\hline 42,66 & 33,16 & 7,65 & 0,40 & 2,40 & 98,79 \\
\hline 41,06 & 40,42 & 1,21 & nd & 1,69 & 98,62 \\
\hline 43,94 & 33,51 & 6,58 & 0,47 & 2,10 & 99,23 \\
\hline 45,02 & 33,23 & 6,67 & 0,42 & 2,20 & 99,15 \\
\hline 41,62 & 41,04 & 1,25 & nd & 1,80 & 98,18 \\
\hline 43,74 & 33,21 & 6,60 & 0,46 & 2,52 & 99,70 \\
\hline 42,23 & 33,12 & 6,94 & 0,21 & 2,65 & 98,85 \\
\hline 42,67 & 33,63 & 7,79 & 0,35 & 2,07 & 98,63 \\
\hline 42,55 & 33,26 & 7,51 & 0,48 & 2,17 & 98,29 \\
\hline 42,16 & 33,91 & 8,32 & 0,43 & 2,16 & 99,78 \\
\hline 41,03 & 33,67 & 8,42 & 0,41 & 2,25 & 98,87 \\
\hline 42,52 & 33,72 & 7,51 & 0,44 & 2,51 & 99,72 \\
\hline 40,67 & 34,45 & 8,24 & 0,39 & 1,97 & 98,25 \\
\hline 39,85 & 35,28 & 8,58 & 0,49 & 1,79 & 98,59 \\
\hline 40,25 & 35,91 & 8,01 & 0,37 & 1,47 & 98,19 \\
\hline 50,88 & 32,47 & 0,97 & nd & 3,65 & 98,31 \\
\hline 48,75 & 34,18 & 1,00 & nd & 3,64 & 99,46 \\
\hline 45,70 & 35,17 & 1,03 & nd & 3,54 & 99,15 \\
\hline 48,43 & 34,01 & 1,00 & nd & 3,49 & 99,32 \\
\hline 55,31 & 31,77 & 0,94 & nd & 4,09 & 99,62 \\
\hline 54,48 & 31,27 & 0,94 & nd & 3,95 & 98,19 \\
\hline 55,30 & 29,22 & 0,84 & nd & 6,38 & 100,88 \\
\hline 57,87 & 28,55 & 0,82 & nd & 5,99 & 101,04 \\
\hline 55,03 & 30,24 & 0,87 & nd & 5,74 & 100,58 \\
\hline 57,71 & 29,19 & 0,84 & nd & 5,73 & 101,13 \\
\hline 51,54 & 31,32 & 0,90 & nd & 5,07 & 100,55 \\
\hline 57,85 & 28,73 & 0,83 & nd & 5,70 & 100,77 \\
\hline 44,46 & 34,92 & 1,03 & nd & 5,43 & 98,42 \\
\hline 54,50 & 29,53 & 0,85 & nd & 5,67 & 100,77 \\
\hline
\end{tabular}




\begin{tabular}{|c|c|c|c|c|c|}
\hline 50,34 & 31,52 & 0,92 & nd & 4,67 & 98,95 \\
\hline 51,10 & 30,99 & 0,88 & nd & 6,13 & 100,59 \\
\hline 52,89 & 30,24 & 0,86 & nd & 6,04 & 100,56 \\
\hline 54,49 & 29,87 & 0,86 & nd & 5,80 & 100,57 \\
\hline 55,58 & 28,95 & 0,84 & nd & 5,71 & 99,85 \\
\hline 55,97 & 28,27 & 0,82 & nd & 5,84 & 99,47 \\
\hline 56,64 & 28,60 & 0,83 & nd & 5,68 & 100,25 \\
\hline 56,65 & 29,30 & 0,84 & nd & 5,85 & 100,96 \\
\hline 56,87 & 28,51 & 0,83 & nd & 5,79 & 99,98 \\
\hline 57,04 & 29,19 & 0,84 & nd & 5,84 & 100,72 \\
\hline 56,84 & 28,45 & 0,83 & nd & 5,93 & 100,02 \\
\hline 56,86 & 28,97 & 0,84 & nd & 5,84 & 100,48 \\
\hline 57,12 & 28,74 & 0,83 & nd & 5,92 & 100,59 \\
\hline 56,78 & 28,49 & 0,83 & nd & 5,71 & 99,85 \\
\hline 56,78 & 29,06 & 0,84 & nd & 5,83 & 100,79 \\
\hline 55,94 & 28,78 & 0,84 & nd & 5,85 & 99,93 \\
\hline 54,82 & 29,77 & 0,85 & nd & 6,09 & 100,66 \\
\hline 53,18 & 30,41 & 0,87 & nd & 6,06 & 100,36 \\
\hline 49,51 & 31,60 & 0,92 & nd & 4,82 & 99,17 \\
\hline 49,76 & 31,81 & 0,92 & nd & 5,15 & 99,91 \\
\hline 46,31 & 33,87 & 0,96 & nd & 5,10 & 100,51 \\
\hline 51,56 & 31,23 & 0,90 & nd & 5,69 & 99,91 \\
\hline 52,66 & 30,80 & 0,89 & nd & 5,49 & 100,14 \\
\hline 53,54 & 30,59 & 0,88 & nd & 5,78 & 100,68 \\
\hline 53,96 & 30,93 & 0,89 & nd & 5,70 & 101,11 \\
\hline 53,95 & 30,50 & 0,88 & nd & 5,62 & 100,56 \\
\hline 54,28 & 29,57 & 0,86 & nd & 5,77 & 99,70 \\
\hline 54,33 & 30,21 & 0,87 & nd & 5,65 & 100,39 \\
\hline 52,99 & 28,10 & 0,83 & nd & 6,80 & 97,67 \\
\hline 49,24 & 27,32 & 0,83 & nd & 6,89 & 94,82 \\
\hline 55,39 & 30,01 & 0,86 & nd & 5,54 & 100,83 \\
\hline 55,73 & 29,69 & 0,85 & nd & 5,82 & 100,93 \\
\hline 55,95 & 29,78 & 0,86 & nd & 5,79 & 100,97 \\
\hline 55,58 & 29,93 & 0,87 & nd & 5,74 & 100,49 \\
\hline 55,88 & 29,56 & 0,85 & nd & 5,67 & 100,60 \\
\hline 56,11 & 30,03 & 0,86 & nd & 5,71 & 101,27 \\
\hline 55,69 & 29,42 & 0,86 & nd & 5,62 & 99,92 \\
\hline 56,19 & 29,46 & 0,85 & nd & 5,66 & 100,63 \\
\hline 56,14 & 29,75 & 0,86 & nd & 5,86 & 100,94 \\
\hline 56,28 & 30,14 & 0,87 & nd & 5,70 & 101,19 \\
\hline 56,96 & 29,86 & 0,85 & nd & 5,63 & 101,82 \\
\hline 56,21 & 29,35 & 0,85 & nd & 5,75 & 100,16 \\
\hline 56,46 & 29,77 & 0,86 & nd & 5,73 & 101,16 \\
\hline 56,12 & 29,99 & 0,87 & nd & 5,68 & 100,78 \\
\hline 56,10 & 30,22 & 0,87 & nd & 5,67 & 100,97 \\
\hline 55,55 & 30,06 & 0,87 & nd & 5,60 & 100,56 \\
\hline 55,90 & 29,84 & 0,86 & nd & 5,83 & 100,76 \\
\hline 55,79 & 29,98 & 0,87 & nd & 5,60 & 100,39 \\
\hline 55,48 & 30,04 & 0,87 & nd & 5,74 & 100,43 \\
\hline 55,70 & 30,09 & 0,87 & nd & 5,78 & 100,63 \\
\hline
\end{tabular}




$\begin{array}{rrrrrr}55,34 & 30,28 & 0,87 & \text { nd } & 5,84 & 101,03 \\ 55,50 & 29,54 & 0,85 & \text { nd } & 5,92 & 100,50 \\ 54,62 & 30,43 & 0,87 & \text { nd } & 5,95 & 100,87 \\ 53,86 & 30,80 & 0,88 & \text { nd } & 6,04 & 100,76 \\ 52,96 & 30,68 & 0,89 & \text { nd } & 5,85 & 99,38 \\ 50,82 & 31,52 & 0,89 & \text { nd } & 5,51 & 101,31 \\ 55,70 & 28,84 & 0,83 & \text { nd } & 5,59 & 100,73 \\ 56,60 & 28,65 & 0,82 & \text { nd } & 6,08 & 101,47\end{array}$


Supplementary Table Feldspar Analyses.

\begin{tabular}{|c|c|c|c|c|c|c|c|c|c|c|c|c|}
\hline S\$ & Type & An & $\mathbf{A b}$ & Or & $\mathrm{SiO2}$ & Al2O3 & TiO2 & $\mathrm{FeO}$ & $\mathrm{MgO}$ & $\mathrm{CaO}$ & $\mathrm{Na} 2 \mathrm{O}$ & $\mathrm{K} 2 \mathrm{O}$ \\
\hline \multicolumn{13}{|c|}{ NWA 8694} \\
\hline 13 & 180417 & 27,27 & 66,80 & 5,93 & 60,39 & 23,38 & 0,10 & 0,53 & 0,01 & 5,56 & 7,51 & 1,02 \\
\hline 18 & 180417 & 27,03 & 65,88 & 7,09 & 60,01 & 23,06 & 0,04 & 0,37 & bd & 5,47 & 7,36 & 1,20 \\
\hline 24 & 180417 & 26,85 & 65,89 & 7,26 & 59,27 & 22,96 & bd & 0,73 & 0,05 & 5,46 & 7,41 & 1,25 \\
\hline 30 & 130417 & 26,51 & 64,30 & 9,19 & 60,98 & 23,38 & 0,01 & 0,39 & 0,06 & 5,45 & 7,30 & 1,59 \\
\hline 67 & 180417 & 26,20 & 66,41 & 7,39 & 61,37 & 24,12 & 0,07 & 0,53 & 0,03 & 5,52 & 7,72 & 1,30 \\
\hline 69 & 180417 & 25,26 & 69,24 & 5,50 & 61,89 & 24,23 & 0,08 & 0,86 & 0,03 & 5,32 & 8,07 & 0,98 \\
\hline 56 & 180417 & 25,07 & 66,67 & 8,27 & 61,86 & 25,22 & 0,09 & 0,83 & 0,02 & 5,33 & 7,83 & 1,48 \\
\hline 23 & 130417 & 25,06 & 70,28 & 4,65 & 61,66 & 24,75 & 0,07 & 0,57 & bd & 5,38 & 8,31 & 0,84 \\
\hline 57 & 180417 & 25,00 & 66,18 & 8,82 & 61,04 & 23,70 & 0,06 & 0,70 & 0,29 & 5,06 & 7,38 & 1,50 \\
\hline 45 & 180417 & 24,44 & 69,65 & 5,91 & 62,08 & 23,94 & 0,11 & 0,49 & 0,04 & 5,14 & 8,08 & 1,04 \\
\hline 19 & 180417 & 24,44 & 67,20 & 8,37 & 61,08 & 22,69 & 0,08 & 0,70 & 0,03 & 4,91 & 7,48 & 1,42 \\
\hline 22 & 130417 & 24,41 & 70,34 & 5,25 & 61,36 & 24,27 & 0,01 & 0,73 & bd & 5,07 & 8,09 & 0,91 \\
\hline 29 & 130417 & 24,37 & 67,95 & 7,68 & 60,55 & 23,58 & 0,08 & 0,62 & 0,12 & 4,95 & 7,61 & 1,30 \\
\hline 25 & 130417 & 24,29 & 71,51 & 4,21 & 62,11 & 24,13 & 0,03 & 0,68 & bd & 4,92 & 7,98 & 0,70 \\
\hline 55 & 180417 & 23,48 & 70,32 & 6,19 & 62,44 & 24,35 & 0,08 & 0,91 & 0,05 & 5,03 & 8,35 & 1,11 \\
\hline 68 & 180417 & 23,18 & 66,02 & 10,81 & 62,34 & 23,71 & 0,09 & 0,83 & 0,02 & 4,89 & 7,71 & 1,93 \\
\hline 42 & 180417 & 22,05 & 71,65 & 6,30 & 63,10 & 23,35 & 0,05 & 0,57 & 0,01 & 4,63 & 8,30 & 1,10 \\
\hline 46 & 180417 & 21,62 & 71,88 & 6,50 & 62,08 & 23,48 & bd & 0,69 & 0,02 & 4,45 & 8,20 & 1,14 \\
\hline 65 & 180417 & 20,86 & 68,58 & 10,56 & 63,35 & 23,82 & 0,09 & 0,60 & 0,03 & 4,34 & 7,88 & 1,85 \\
\hline 53 & 180417 & 18,93 & 75,33 & 5,73 & 63,42 & 23,04 & 0,13 & 0,34 & 0,06 & 3,90 & 8,58 & 1,00 \\
\hline 50 & 180417 & 17,17 & 73,05 & 9,78 & 64,40 & 22,67 & bd & 0,89 & bd & 3,59 & 8,46 & 1,71 \\
\hline 43 & 180417 & 15,97 & 73,15 & 10,87 & 64,95 & 22,42 & 0,05 & 0,36 & bd & 3,29 & 8,31 & 1,88 \\
\hline 59 & 180417 & 14,29 & 75,13 & 10,58 & 65,35 & 22,59 & 0,08 & 0,49 & bd & 3,02 & 8,76 & 1,86 \\
\hline 64 & & 14,78 & & 17,55 & & & $\mathrm{bd}$ & & bd & 3,07 & 7,74 & 3,04 \\
\hline 60 & 180417 & 13,36 & 58,07 & 28,57 & 63,76 & 21,54 & 0,07 & 0,37 & 0,09 & 2,75 & 6,59 & 4,93 \\
\hline 58 & 180417 & 7,37 & 45,00 & 47,63 & 65,15 & 20,77 & 0,11 & 0,48 & 0,07 & 1,52 & 5,15 & 8,28 \\
\hline 52 & 180417 & 2,89 & 29,83 & 67,28 & 65,88 & 18,69 & 0,11 & 0,85 & 0,02 & 0,60 & 3,36 & 11,53 \\
\hline 44 & 180417 & 2,27 & 27,01 & 70,72 & 65,81 & 19,61 & 0,14 & 0,53 & bd & 0,45 & 3,01 & 11,97 \\
\hline 51 & 180417 & 0,53 & 24,47 & 75,00 & 65,57 & 19,23 & 0,12 & 0,67 & bd & 0,10 & 2,74 & 12,76 \\
\hline 47 & 180417 & 1,15 & 20,08 & 78,77 & 64,67 & 19,16 & 0,02 & 0,47 & 0,01 & 0,23 & 2,30 & 13,73 \\
\hline 63 & 180417 & 0,53 & 98,55 & 0,92 & 66,79 & 22,29 & 0,05 & 0,93 & 0,04 & 0,12 & 11,67 & 0,16 \\
\hline \multicolumn{13}{|c|}{ Chassigny } \\
\hline 55 & 190618 & 20,08 & 66,73 & 13,19 & 64,28 & 22,91 & 0,17 & 0,47 & 0,04 & 3,58 & 6,58 & 1,98 \\
\hline 47 & 190618 & 19,86 & 64,76 & 15,38 & 63,75 & 22,72 & 0,11 & 0,97 & 0,03 & 3,40 & 6,14 & 2,21 \\
\hline 67 & 190618 & 18,10 & 68,41 & 13,49 & 62,03 & 22,08 & 0,15 & 0,47 & 0,01 & 3,50 & 7,32 & 2,19 \\
\hline 50 & 190618 & 17,58 & 68,68 & 13,74 & 64,25 & 23,29 & 0,10 & 0,50 & 0,02 & 3,18 & 6,87 & 2,09 \\
\hline 49 & 190618 & 17,57 & 69,36 & 13,07 & 63,77 & 23,11 & 0,10 & 0,44 & 0,02 & 3,13 & 6,83 & 1,95 \\
\hline 68 & 190618 & 17,37 & 68,37 & 14,26 & 62,72 & 22,33 & 0,11 & 0,57 & 0,04 & 3,43 & 7,46 & 2,37 \\
\hline 60 & 190618 & 16,90 & 71,92 & 11,18 & 63,92 & 22,11 & 0,11 & 0,42 & 0,02 & 3,57 & 8,41 & 1,99 \\
\hline 58 & 190618 & 15,82 & 70,89 & 13,29 & 62,53 & 21,42 & 0,11 & 0,49 & 0,12 & 3,21 & 7,94 & 2,26 \\
\hline 57 & 190618 & 15,71 & 73,54 & 10,74 & 63,71 & 21,43 & 0,15 & 0,53 & 0,03 & 3,07 & 7,94 & 1,76 \\
\hline 56 & 190618 & 15,37 & 65,90 & 18,72 & 64,70 & 21,72 & 0,08 & 0,56 & 0,04 & 2,75 & 6,51 & 2,81 \\
\hline 64 & 190618 & 14,94 & 71,08 & 13,98 & 63,86 & 21,73 & 0,10 & 0,42 & 0,02 & 2,94 & 7,74 & 2,31 \\
\hline 61 & 190618 & 14,89 & 71,52 & 13,59 & 62,49 & 21,79 & 0,14 & 0,35 & 0,01 & 3,08 & 8,17 & 2,36 \\
\hline 53 & 190618 & 14,49 & 76,92 & 8,59 & 63,37 & 21,51 & 0,10 & 0,40 & 0,02 & 2,98 & 8,73 & 1,48 \\
\hline 63 & 190618 & 14,40 & 69,89 & 15,71 & 63,21 & 21,64 & 0,07 & 0,47 & bd & 2,93 & 7,85 & 2,68 \\
\hline 66 & 190618 & 14,31 & 72,31 & 13,38 & 63,39 & 21,42 & 0,11 & 0,42 & 0,05 & 2,84 & 7,92 & 2,23 \\
\hline
\end{tabular}




$\begin{array}{crrrrllllllll}59 & 190618 & 14,20 & 67,46 & 18,34 & 63,38 & 21,57 & 0,14 & 0,71 & 0,02 & 2,80 & 7,35 & 3,04 \\ 48 & 190618 & 14,14 & 73,71 & 12,16 & 63,37 & 22,04 & 0,16 & 0,39 & 0,03 & 2,77 & 7,99 & 2,00 \\ 65 & 190618 & 11,51 & 64,79 & 23,70 & 63,63 & 20,72 & 0,09 & 0,50 & 0,02 & 2,36 & 7,35 & 4,09 \\ 62 & 190618 & 11,40 & 59,57 & 29,03 & 63,15 & 21,05 & 0,17 & 0,35 & 0,03 & 2,31 & 6,68 & 4,95 \\ 54 & 190618 & 9,45 & 65,07 & 25,48 & 63,52 & 20,16 & 0,12 & 0,48 & 0,04 & 1,93 & 7,35 & 4,37 \\ \text { NWA 2737 } & & & & & & & & & & & & \\ 138 & 181217 & 12,37 & 70,88 & 16,76 & 66,03 & 21,87 & 0,15 & 0,38 & 0,01 & 2,59 & 8,22 & 2,95 \\ 143 & 181217 & 9,72 & 73,53 & 16,75 & 64,30 & 21,75 & 0,10 & 0,68 & 0,21 & 2,08 & 8,75 & 3,03 \\ 140 & 181217 & 8,56 & 73,37 & 18,07 & 66,78 & 21,31 & 0,14 & 0,60 & 0,03 & 1,75 & 8,32 & 3,10 \\ 94 & 181217 & 6,09 & 75,93 & 17,98 & 66,09 & 21,06 & 0,16 & 0,62 & 0,06 & 1,21 & 8,36 & 3,02 \\ 93 & 181217 & 6,05 & 74,82 & 19,13 & 68,17 & 20,56 & 0,14 & 0,43 & 0,02 & 1,21 & 8,22 & 3,19 \\ 91 & 181217 & 5,80 & 75,17 & 19,03 & 66,97 & 20,54 & 0,16 & 0,42 & 0,01 & 1,21 & 8,56 & 3,29 \\ 95 & 181217 & 5,68 & 75,78 & 18,54 & 67,43 & 20,49 & 0,19 & 0,55 & 0,03 & 1,17 & 8,61 & 3,20 \\ 89 & 181217 & 5,44 & 74,90 & 19,65 & 66,73 & 20,83 & 0,18 & 0,41 & 0,02 & 1,15 & 8,65 & 3,45 \\ 96 & 181217 & 5,05 & 74,73 & 20,22 & 67,11 & 20,05 & 0,21 & 0,60 & 0,06 & 1,01 & 8,34 & 3,44 \\ 92 & 181217 & 5,03 & 74,44 & 20,53 & 67,72 & 19,85 & 0,15 & 0,25 & 0,01 & 0,98 & 8,11 & 3,41 \\ 49 & 181217 & 4,82 & 75,36 & 19,82 & 65,40 & 20,96 & 0,21 & 0,34 & b d & 1,01 & 8,75 & 3,49 \\ 87 & 181217 & 4,75 & 76,26 & 19,00 & 67,01 & 21,02 & 0,18 & 0,43 & 0,02 & 0,97 & 8,63 & 3,27 \\ 86 & 181217 & 4,74 & 76,32 & 18,95 & 67,04 & 20,86 & 0,17 & 0,29 & 0,01 & 0,99 & 8,90 & 3,36 \\ 47 & 181217 & 4,71 & 75,04 & 20,26 & 67,05 & 22,68 & 0,17 & 0,34 & 0,02 & 0,93 & 8,18 & 3,35 \\ 84 & 181217 & 4,58 & 75,28 & 20,14 & 68,29 & 20,42 & 0,12 & 0,40 & 0,02 & 0,91 & 8,40 & 3,42 \\ 85 & 181217 & 4,54 & 76,39 & 19,07 & 66,33 & 20,81 & 0,17 & 0,29 & 0,02 & 0,98 & 9,01 & 3,41 \\ 90 & 181217 & 4,51 & 76,33 & 19,15 & 66,98 & 20,47 & 0,16 & 0,48 & 0,01 & 0,92 & 8,51 & 3,26 \\ 88 & 181217 & 4,04 & 76,85 & 19,11 & 68,11 & 20,05 & 0,11 & 0,43 & b d & 0,84 & 8,77 & 3,32\end{array}$




\begin{tabular}{|c|c|}
\hline \multicolumn{2}{|l|}{$\begin{array}{l}\text { Total } \\
\end{array}$} \\
\hline 98,57 & \\
\hline 97,56 & \\
\hline 97,21 & \\
\hline 99,24 & \\
\hline 100,65 & \\
\hline 101,64 & \\
\hline 102,71 & \\
\hline 101,66 & \\
\hline 99,74 & \\
\hline 101,36 & \\
\hline 98,49 & \\
\hline 100,46 & \\
\hline 98,83 & \\
\hline 100,61 & \\
\hline 102,31 & \\
\hline 101,54 & \\
\hline 101,23 & \\
\hline 100,37 & \\
\hline 102,14 & \\
\hline 100,57 & \\
\hline 101,74 & \\
\hline 101,26 & \\
\hline 102,23 & \\
\hline 100,56 & \\
\hline 100,32 & \\
\hline 101,54 & \\
\hline 101,11 & \\
\hline 101,52 & \\
\hline 101,22 & \\
\hline 100,65 & \\
\hline 102,12 & \\
\hline 100,00 & \\
\hline 99,33 & \\
\hline 97,74 & \\
\hline 100,30 & \\
\hline 99,43 & \\
\hline 99,02 & \\
\hline 100,57 & \\
\hline 98,11 & \\
\hline 98,66 & \\
\hline 99,20 & \\
\hline 99,13 & \\
\hline 98,39 & \\
\hline 98,59 & \\
\hline $98,8 \mathrm{~s}$ & \\
\hline 98,40 & \\
\hline
\end{tabular}


99,04

98,79

98,83

98,70

98,02

102,29

101,06

102,08

100,61

102,05

101,15

101,62

101,44

100,84

100,47

100,19

101,51

101,56

102,72

102,03

101,07

100,77

101,64 


\begin{tabular}{|c|c|c|c|c|c|c|c|c|c|c|}
\hline M.I. & Kcode & $\mathrm{SiO2}$ & Al2O3 & $\mathrm{FeO}$ & MgO & $\mathrm{CaO}$ & $\mathrm{Na2O}$ & K2O & & Total \\
\hline \multicolumn{11}{|c|}{ Al-poor } \\
\hline 3 & 130417 & 67,23 & 21,17 & 1,39 & 0,32 & 0,42 & 10,10 & \multicolumn{2}{|c|}{0,03 nd } & 100,65 \\
\hline 28 & 180417 & 72,51 & 16,53 & 0,72 & 0,02 & 0,10 & 9,10 & 0,06 & 0,06 & 99,41 \\
\hline 39 & 180417 & 71,87 & 15,42 & 1,69 & 0,05 & 0,17 & 8,09 & \multicolumn{2}{|c|}{$0,44 \mathrm{bd}$} & 97,81 \\
\hline 40 & 180417 & 73,07 & 15,58 & \multicolumn{2}{|c|}{0,99 bd } & 0,20 & 7,26 & 0,54 & 0,02 & 97,82 \\
\hline \multicolumn{11}{|c|}{ Al-rich } \\
\hline 7 & 130417 & 64,28 & 20,93 & \multicolumn{2}{|c|}{$1,19 \mathrm{bd}$} & 0,23 & 10,91 & \multicolumn{2}{|c|}{$0,39 \mathrm{nd}$} & 98,02 \\
\hline 26 & 180417 & 64,08 & 20,96 & 1,44 & 0,06 & 0,15 & 11,50 & 0,18 & 0,02 & 98,40 \\
\hline 27 & 180417 & 64,74 & 21,45 & 1,19 & 0,15 & 0,89 & 11,10 & 0,08 & 0,02 & 99,68 \\
\hline 32 & 130417 & 63,6 & 21,71 & 1,33 & 0,20 & 0,16 & 8,49 & \multicolumn{2}{|c|}{0,86 nd } & 96,64 \\
\hline 33 & 130417 & 64,01 & 21,43 & \multicolumn{2}{|c|}{$0,91 \mathrm{bd}$} & 0,28 & 9,40 & \multicolumn{2}{|c|}{$0,29 \mathrm{nd}$} & 96,67 \\
\hline 62 & 180417 & 67,49 & 21,88 & 0,91 & & 0,15 & 12,24 & 0,09 & 0,25 & 103,06 \\
\hline \multicolumn{11}{|l|}{ K-rich } \\
\hline 21 & 180417 & 71,02 & 14,30 & \multicolumn{2}{|c|}{$1,04 \mathrm{bd}$} & 1,06 & 5,69 & 3,44 & 1,15 & 97,94 \\
\hline 29 & 180417 & 68,92 & 15,38 & 0,90 & 0,02 & 2,24 & 5,14 & 3,96 & 1,29 & 98,23 \\
\hline 30 & 180417 & 70,33 & 15,62 & 0,89 & 0,06 & 1,81 & 5,95 & 3,03 & 0,90 & 98,88 \\
\hline 73 & 121114 & 71,95 & 16,79 & \multicolumn{2}{|c|}{$0,50 \mathrm{bd}$} & 4,01 & 1,47 & \multicolumn{2}{|c|}{$4,21 \mathrm{nd}$} & 99,01 \\
\hline 78 & 100215 & 71,35 & 15,44 & \multicolumn{2}{|c|}{$1,03 \mathrm{bd}$} & 1,31 & 4,27 & 4,81 & 1,18 & 99,47 \\
\hline 80 & 100215 & 76,35 & 15,48 & 1,15 & 0,02 & 2,42 & 3,78 & 3,38 & 1,28 & 103,89 \\
\hline 109 & 100215 & 70,24 & 16,43 & 0,88 & 0,02 & 2,58 & 3,78 & 5,20 & 1,38 & 100,53 \\
\hline \multicolumn{11}{|c|}{ Cat-poor } \\
\hline 8 & 130417 & 74,21 & 21,52 & 0,98 & 0,04 & 0,23 & 1,56 & \multicolumn{2}{|c|}{$0,05 \mathrm{nd}$} & 98,94 \\
\hline 45 & 121114 & 79,44 & 17,31 & 0,93 & 0,01 & 0,00 & 0,48 & \multicolumn{2}{|c|}{$1,34 \mathrm{nd}$} & 99,53 \\
\hline 46 & 121114 & 75,38 & 17,89 & \multicolumn{2}{|c|}{0,98 bd } & 1,69 & 0,54 & \multicolumn{2}{|c|}{$1,50 \mathrm{nd}$} & 99,16 \\
\hline 76 & 100215 & 72,82 & 23,05 & \multicolumn{2}{|c|}{$1,09 \mathrm{bd}$} & 0,05 & 3,07 & \multicolumn{2}{|c|}{0,10 nd } & 100,25 \\
\hline 79 & 100215 & 77,44 & 16,64 & 1,03 & 0,01 & 0,00 & 3,91 & \multicolumn{2}{|c|}{$0,27 \mathrm{nd}$} & 99,42 \\
\hline 105 & 100215 & 71,56 & 22,53 & 1,02 & 0,01 & 0,27 & 2,69 & \multicolumn{2}{|c|}{$0,08 \mathrm{nd}$} & 98,48 \\
\hline 110 & 100215 & 76,41 & 17,38 & \multicolumn{2}{|c|}{$0,73 \mathrm{bd}$} & 0,03 & 3,88 & \multicolumn{2}{|c|}{$0,31 \mathrm{nd}$} & 98,92 \\
\hline
\end{tabular}


Table S2. All LA-ICP-MS analyses for NWA 8694 and Chassigny.

\begin{tabular}{|c|c|c|c|c|c|c|c|}
\hline \multirow{3}{*}{ 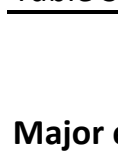 } & \multirow{2}{*}{$\begin{array}{l}\text { olivine } \\
\text { 26-NWA869، }\end{array}$} & \multirow{2}{*}{$\begin{array}{l}\text { olivine } \\
\text { 27-NWA86 }\end{array}$} & \multirow{2}{*}{$\begin{array}{l}\text { olivine } \\
\text { 28-NWA869 }\end{array}$} & olivine & olivine & \multicolumn{2}{|c|}{ pyroxene pyroxene } \\
\hline & & & & $\angle 29-N W A 869<$ & $\angle 30$-NWA869<3 & ¿31-NWA869 & $\angle 32-N W A 869$ \\
\hline & \multicolumn{7}{|c|}{ Major elements (wt. \%) } \\
\hline $\mathrm{SiO}_{2}$ & 35,3 & 35,1 & 35,1 & 35,4 & 35,2 & 52,2 & 52,6 \\
\hline $\mathrm{Al}_{2} \mathrm{O}_{3}$ & 0,02 & 0,02 & 0,05 & 0,02 & 0,02 & 0,74 & 0,66 \\
\hline $\mathrm{TiO}_{2}$ & 0,022 & 0,024 & 0,035 & 0,030 & 0,018 & 0,180 & 0,157 \\
\hline $\mathrm{Cr}_{2} \mathrm{O}_{3}$ & 0,018 & 0,017 & 0,186 & 0,020 & 0,019 & 0,853 & 0,408 \\
\hline FеOT & 38,02 & 38,44 & 38,38 & 38,24 & 38,24 & 21,97 & 22,00 \\
\hline Mno & 0,839 & 0,824 & 0,839 & 0,834 & 0,843 & 0,768 & 0,755 \\
\hline MgO & 25,50 & 25,35 & 25,36 & 25,22 & 25,42 & 18,82 & 18,83 \\
\hline $\mathrm{CaO}$ & 0,24 & 0,21 & 0,21 & 0,20 & 0,24 & 5,18 & 4,85 \\
\hline $\mathrm{Na}_{2} \mathrm{O}$ & 0,01 & 0,02 & 0,02 & 0,02 & 0,02 & 0,13 & 0,14 \\
\hline $\mathrm{K}_{2} \mathrm{O}$ & 0,003 & 0,004 & 0,007 & 0,006 & 0,006 & 0,012 & 0,011 \\
\hline $\mathrm{P}_{2} \mathrm{O}_{5}$ & 0,03 & 0,05 & 0,02 & 0,01 & 0,02 & 0,00 & 0,01 \\
\hline \multicolumn{8}{|c|}{ Trace elements (ppm) } \\
\hline Li & 3,7 & 5,0 & 5,2 & 3,9 & 4,7 & 4,1 & 3,8 \\
\hline $\mathrm{Be}$ & 0,01 & 0,01 & 0,01 & 0,01 & 0,01 & 0,11 & 0,08 \\
\hline B & 1,0 & 0,9 & 1,3 & 0,8 & 0,9 & 3,4 & 3,1 \\
\hline $\mathbf{S}$ & 0,01 & 0,01 & 0,01 & 0,01 & 0,01 & 0,01 & 0,01 \\
\hline Sc & 7,1 & 6,7 & 6,8 & 6,6 & 6,7 & 25,9 & 26,9 \\
\hline V & 6 & 6 & 21 & 7 & 7 & 142 & 116 \\
\hline $\mathrm{Cr}$ & 127 & 115 & 1274 & 134 & 132 & 5835 & 2793 \\
\hline Co & 124 & 122 & 125 & 125 & 124 & 55 & 56 \\
\hline $\mathrm{Ni}$ & 346 & 338 & 352 & 344 & 346 & 110 & 114 \\
\hline $\mathrm{Cu}$ & 2 & 1 & 5 & 1 & 1 & 4 & 4 \\
\hline Zn & 108 & 107 & 106 & 114 & 111 & 94 & 81 \\
\hline Ga & 0,2 & 0,1 & 0,3 & 0,2 & 0,1 & 2,0 & 1,4 \\
\hline Ge & 1,4 & 1,2 & 1,3 & 1,2 & 1,3 & 2,2 & 2,2 \\
\hline As & 0,1 & 0,0 & 0,0 & 0,0 & 0,1 & 0,0 & 0,0 \\
\hline Se & 0,1 & 0,1 & 0,0 & 0,1 & 0,0 & 0,0 & 0,0 \\
\hline $\mathbf{R b}$ & 0,1 & 0,1 & 0,2 & 0,2 & 0,2 & 0,4 & 0,3 \\
\hline $\mathrm{Sr}$ & 3 & 3 & 4 & 3 & 2 & 10 & 9 \\
\hline Y & 0,56 & 0,45 & 0,42 & 0,49 & 0,43 & 2,96 & 2,58 \\
\hline $\mathrm{Zr}$ & 0,16 & 0,42 & 0,21 & 0,67 & 0,17 & 1,94 & 1,14 \\
\hline Nb & 0,00 & 0,01 & 0,01 & 0,01 & 0,00 & 0,24 & 0,12 \\
\hline Mo & 0,083 & 0,079 & 0,095 & 0,087 & 0,102 & 0,103 & 0,087 \\
\hline \multicolumn{8}{|l|}{$\mathrm{Ru}$} \\
\hline \multicolumn{8}{|l|}{$\mathrm{Rh}$} \\
\hline \multicolumn{8}{|l|}{$\mathrm{Pd}$} \\
\hline Ag & 0,001 & 0,001 & 0,002 & 0,001 & 0,001 & 0,002 & 0,002 \\
\hline Cd & 0,111 & 0,071 & 0,082 & 0,170 & 0,214 & 0,105 & 0,089 \\
\hline In & 0,004 & 0,003 & 0,004 & 0,005 & 0,005 & 0,009 & 0,008 \\
\hline Sn & 0,024 & 0,019 & 0,017 & 0,019 & 0,022 & 0,036 & 0,028 \\
\hline Sb & 0,00 & 0,00 & 0,00 & 0,01 & 0,02 & 0,00 & 0,00 \\
\hline Te & 0,1 & 0,0 & 0,0 & 0,1 & 0,0 & 0,1 & 0,2 \\
\hline Cs & 0,0 & 0,0 & 0,1 & 0,1 & 0,1 & 0,1 & 0,1 \\
\hline
\end{tabular}




\begin{tabular}{|c|c|c|c|c|c|c|c|}
\hline $\mathrm{Ba}$ & 1 & 1 & 1 & 1 & 1 & 1 & 1 \\
\hline La & 0,005 & 0,009 & 0,006 & 0,006 & 0,001 & 0,103 & 0,171 \\
\hline $\mathrm{Ce}$ & 0,006 & 0,012 & 0,005 & 0,006 & 0,002 & 0,452 & 0,547 \\
\hline $\mathrm{Pr}$ & 0,001 & 0,002 & 0,001 & 0,001 & 0,000 & 0,103 & 0,102 \\
\hline Nd & 0,007 & 0,010 & 0,008 & 0,004 & 0,003 & 0,670 & 0,601 \\
\hline Sm & 0,003 & 0,004 & 0,004 & 0,004 & 0,002 & 0,286 & 0,229 \\
\hline Eu & 0,001 & 0,001 & 0,001 & 0,001 & 0,001 & 0,063 & 0,057 \\
\hline Gd & 0,023 & 0,018 & 0,012 & 0,014 & 0,017 & 0,391 & 0,344 \\
\hline Tb & 0,006 & 0,004 & 0,004 & 0,005 & 0,005 & 0,079 & 0,063 \\
\hline Dy & 0,070 & 0,055 & 0,048 & 0,053 & 0,050 & 0,537 & 0,450 \\
\hline Ho & 0,023 & 0,017 & 0,013 & 0,018 & 0,017 & 0,115 & 0,101 \\
\hline $\mathrm{Er}$ & 0,082 & 0,065 & 0,065 & 0,077 & 0,064 & 0,343 & 0,292 \\
\hline $\mathrm{Tm}$ & 0,015 & 0,013 & 0,011 & 0,013 & 0,012 & 0,045 & 0,043 \\
\hline Yb & 0,101 & 0,098 & 0,087 & 0,097 & 0,079 & 0,291 & 0,263 \\
\hline Lu & 0,019 & 0,017 & 0,018 & 0,018 & 0,016 & 0,045 & 0,044 \\
\hline $\mathrm{Hf}$ & 0,004 & 0,011 & 0,007 & 0,014 & 0,005 & 0,065 & 0,048 \\
\hline $\mathrm{Ta}$ & 0,000 & 0,000 & 0,001 & 0,001 & 0,000 & 0,007 & 0,003 \\
\hline $\mathbf{w}$ & 0,005 & 0,003 & 0,008 & 0,003 & 0,003 & 0,019 & 0,029 \\
\hline \multicolumn{8}{|l|}{$\operatorname{Re}$} \\
\hline \multicolumn{8}{|l|}{ Os } \\
\hline \multicolumn{8}{|l|}{ Ir } \\
\hline \multicolumn{8}{|l|}{$\mathrm{Pt}$} \\
\hline \multicolumn{8}{|l|}{$\mathrm{Au}$} \\
\hline TI & 0,001 & 0,001 & 0,002 & 0,001 & 0,001 & 0,003 & 0,003 \\
\hline $\mathrm{Pb}$ & 0,303 & 0,093 & 0,219 & 0,110 & 0,055 & 0,223 & 0,192 \\
\hline $\mathrm{Bi}$ & 0,003 & 0,002 & 0,002 & 0,004 & 0,005 & 0,003 & 0,001 \\
\hline Th & 0,000 & 0,001 & 0,001 & 0,001 & 0,000 & 0,017 & 0,018 \\
\hline U & 0,035 & 0,024 & 0,046 & 0,021 & 0,024 & 0,109 & 0,103 \\
\hline
\end{tabular}


pyroxene pyroxene pyroxene mesostasis mesostasis mesostasis mesostasis mesostasis 33-NWA869<34-NWA869<35-NWA869<36-NWA869<37-NWA869<38-NWA869<39-NWA869< 40-NWA869 <

$\begin{array}{rrrrrrrr}51,1 & 52,7 & 52,6 & 42,5 & 57,9 & 58,1 & 59,6 & 60,5 \\ 0,64 & 0,65 & 0,64 & 5,74 & 21,72 & 19,84 & 23,84 & 23,77 \\ 0,146 & 0,150 & 0,155 & 0,072 & 0,073 & 0,055 & 0,078 & 0,076 \\ 0,373 & 0,338 & 0,411 & 0,009 & 0,003 & 0,002 & 0,001 & 0,001 \\ 22,69 & 22,87 & 21,85 & 27,34 & 4,40 & 2,65 & 0,55 & 0,24 \\ 0,765 & 0,792 & 0,771 & 0,598 & 0,063 & 0,050 & 0,009 & 0,006 \\ 19,14 & 19,18 & 18,88 & 18,14 & 1,77 & 1,25 & 0,35 & 0,28 \\ 5,33 & 3,51 & 4,96 & 2,17 & 4,50 & 5,44 & 4,89 & 4,62 \\ 0,16 & 0,12 & 0,13 & 2,21 & 7,46 & 7,18 & 9,04 & 8,42 \\ 0,020 & 0,024 & 0,019 & 0,441 & 1,82 & 3,35 & 1,50 & 2,04 \\ 0,01 & 0,01 & 0,01 & 0,82 & 0,34 & 2,04 & 0,12 & 0,11 \\ & & & & & & & \\ 3,6 & 3,8 & 3,8 & 15,0 & 34,4 & 35,4 & 119,8 & 105,2 \\ 0,13 & 0,08 & 0,07 & 0,40 & 1,10 & 1,06 & 1,17 & 1,14 \\ 3,3 & 4,1 & 2,9 & 5,0 & 8,1 & 7,8 & 3,1 & 4,9 \\ 0,01 & 0,01 & 0,01 & 0,03 & 0,92 & 0,02 & 0,00 & -0,01 \\ 25,7 & 23,4 & 27,1 & 6,0 & 4,5 & 4,6 & 8,8 & 5,6 \\ 109 & 94 & 119 & 3 & 1 & 1 & 1 & 1 \\ 2552 & 2315 & 2810 & 63 & 18 & 11 & 7 & 7 \\ 59 & 56 & 54 & 85 & 156 & 16 & 1 & 0 \\ 126 & 113 & 108 & 261 & 100 & 42 & 67 & 56 \\ 5 & 8 & 3 & 16 & 22 & 8 & 4 & 4 \\ 78 & 88 & 81 & 88 & 15 & 12 & 4 & 3 \\ 1,4 & 1,5 & 1,3 & 4,8 & 15,3 & 15,9 & 16,7 & 17,2 \\ 2,1 & 2,2 & 2,4 & 1,3 & 0,9 & 0,6 & -0,4 & -0,3 \\ 0,0 & 0,0 & 0,0 & 0,0 & -0,1 & -0,2 & -0,1 & -0,8 \\ 0,0 & 0,0 & 0,0 & 0,0 & 2,4 & 0,2 & -1,3 & -0,2 \\ 0,8 & 1,0 & 0,9 & 8,1 & 42,5 & 73,7 & 24,4 & 33,6 \\ 12 & 12 & 9 & 196 & 601 & 681 & 761 & 765 \\ 3,46 & 2,44 & 2,48 & 4,19 & 2,23 & 11,01 & 0,21 & 0,48 \\ 3,83 & 2,94 & 1,64 & 2,13 & 13,58 & 2,86 & 0,30 & 14,11 \\ 0,46 & 0,53 & 0,18 & 5,53 & 2,06 & 0,36 & 0,09 & 2,79 \\ 0,089 & 0,118 & 0,085 & 0,204 & 0,423 & 0,367 & 1,256 & 0,973\end{array}$

$\begin{array}{rrrrrrrr}0,031 & 0,002 & 0,003 & 0,011 & 0,032 & 0,057 & -0,011 & 0,065 \\ 0,099 & 0,115 & 0,077 & 0,044 & 0,101 & 0,040 & 0,250 & 0,246 \\ 0,040 & 0,007 & 0,008 & 0,010 & 0,013 & 0,012 & 0,123 & 0,035 \\ 0,052 & 0,047 & 0,037 & 0,179 & 0,198 & 0,565 & 0,186 & 0,218 \\ 0,00 & 0,00 & 0,00 & 0,00 & -0,04 & -0,04 & -0,27 & -0,17 \\ 0,1 & 0,1 & 0,1 & 0,6 & 0,5 & 0,2 & -0,1 & 0,0 \\ 0,1 & 0,1 & 0,1 & 0,7 & 2,3 & 2,5 & 6,0 & 4,9\end{array}$




$\begin{array}{rrrrrrrr}1 & 3 & 1 & 106 & 350 & 538 & 442 & 559 \\ 0,393 & 0,198 & 0,071 & 11,98 & 9,89 & 38,03 & 3,39 & 3,84 \\ 1,362 & 0,529 & 0,289 & 23,60 & 17,40 & 81,14 & 4,94 & 5,65 \\ 0,250 & 0,098 & 0,073 & 3,06 & 2,01 & 10,57 & 0,43 & 0,71 \\ 1,425 & 0,530 & 0,471 & 12,93 & 8,12 & 41,78 & 1,50 & 2,55 \\ 0,435 & 0,195 & 0,211 & 2,12 & 1,34 & 6,74 & 0,16 & 0,29 \\ 0,084 & 0,043 & 0,052 & 0,63 & 1,63 & 2,18 & 1,89 & 2,02 \\ 0,542 & 0,290 & 0,313 & 1,72 & 0,96 & 5,29 & 0,12 & 0,33 \\ 0,097 & 0,057 & 0,059 & 0,202 & 0,125 & 0,598 & 0,016 & 0,034 \\ 0,654 & 0,419 & 0,429 & 1,001 & 0,607 & 2,852 & 0,024 & 0,335 \\ 0,133 & 0,097 & 0,097 & 0,167 & 0,072 & 0,437 & 0,009 & 0,028 \\ 0,376 & 0,287 & 0,289 & 0,362 & 0,152 & 0,845 & 0,003 & 0,069 \\ 0,052 & 0,037 & 0,040 & 0,035 & 0,025 & 0,082 & 0,001 & 0,005 \\ 0,295 & 0,256 & 0,260 & 0,174 & 0,069 & 0,264 & 0,006 & 0,023 \\ 0,045 & 0,042 & 0,041 & 0,027 & 0,011 & 0,034 & 0,023 & -0,004 \\ 0,113 & 0,074 & 0,052 & 0,051 & 0,417 & 0,071 & 0,011 & 0,386 \\ 0,015 & 0,029 & 0,013 & 0,280 & 0,191 & 0,043 & 0,005 & 0,144 \\ 0,043 & 0,083 & 0,032 & 0,569 & 0,150 & 1,392 & 0,011 & 0,555\end{array}$

$\begin{array}{rrrrrrrr}0,004 & 0,004 & 0,003 & 0,012 & 0,032 & 0,030 & 0,008 & -0,008 \\ 0,365 & 0,281 & 0,119 & 2,528 & 6,667 & 9,217 & 4,639 & 6,806 \\ 0,002 & 0,001 & 0,002 & 0,001 & 0,002 & 0,005 & -0,001 & 0,009 \\ 0,046 & 0,050 & 0,027 & 1,378 & 0,996 & 3,137 & 0,043 & 0,434 \\ 0,098 & 0,111 & 0,091 & 0,264 & 0,183 & 0,655 & 0,019 & 0,082\end{array}$


mesostasis mesostasis mesostasis mesostasis mesostasis mesostasis mesos (phos) track 41-NWA869/42-NWA869/43-NWA869/44-NWA869/45-NWA869/46-NWA869<47-NWA8694 48-NWA8694

$\begin{array}{rrrrrrrr}59,2 & 58,3 & 61,7 & 52,7 & 58,6 & 59,5 & 47,5 & 33,2 \\ 22,96 & 19,92 & 18,97 & 15,17 & 23,78 & 24,04 & 15,91 & 12,82 \\ 0,086 & 0,046 & 0,093 & 0,087 & 0,046 & 0,071 & 0,030 & 1,281 \\ 0,001 & 0,003 & 0,001 & 0,052 & 0,002 & 0,000 & 0,000 & 0,308 \\ 1,36 & 3,42 & 2,99 & 11,19 & 2,42 & 0,22 & 1,93 & 23,18 \\ 0,027 & 0,067 & 0,061 & 0,278 & 0,035 & 0,004 & 0,044 & 0,527 \\ 0,79 & 1,76 & 1,79 & 7,65 & 0,94 & 0,14 & 0,26 & 13,71 \\ 5,14 & 4,86 & 1,47 & 5,79 & 5,21 & 5,58 & 15,07 & 11,21 \\ 7,86 & 6,86 & 6,05 & 5,14 & 8,04 & 8,09 & 4,93 & 2,71 \\ 1,95 & 3,18 & 6,52 & 0,87 & 0,89 & 1,82 & 4,15 & 0,56 \\ 0,63 & 1,50 & 0,32 & 1,10 & 0,04 & 0,56 & 10,09 & 0,78 \\ & & & & & & & \\ 31,5 & 28,4 & 21,4 & 24,9 & 24,5 & 34,3 & 19,5 & 2,5 \\ 0,92 & 1,35 & 0,91 & 0,93 & 1,29 & 1,22 & 0,45 & 0,33 \\ 11,2 & 12,6 & 16,3 & 5,2 & 6,6 & 6,9 & 16,3 & 5,4 \\ 0,01 & 0,05 & 0,01 & 0,04 & 0,02 & 0,01 & 0,10 & 0,08 \\ 3,4 & 3,3 & 3,3 & 6,6 & 2,7 & 3,4 & 4,3 & 28,6 \\ 1 & 1 & 1 & 18 & 2 & 1 & 1 & 79 \\ 4 & 18 & 10 & 358 & 14 & 0 & 3 & 2107 \\ 4 & 10 & 11 & 31 & 1 & 0 & 1 & 70 \\ 32 & 50 & 42 & 100 & 24 & 23 & 23 & 613 \\ 3 & 9 & 3 & 15 & 9 & 6 & 39 & 13 \\ 9 & 12 & 11 & 39 & 3 & 5 & 8 & 55 \\ 16,2 & 15,1 & 13,5 & 12,8 & 15,5 & 16,1 & 21,5 & 21,8 \\ 0,6 & 0,5 & 0,6 & 0,8 & 0,6 & 0,5 & -0,1 & 2,5 \\ -0,2 & -0,1 & -0,2 & 0,0 & -0,1 & -0,2 & -0,4 & 0,2 \\ 0,5 & -0,7 & -0,2 & -0,4 & 0,3 & 0,2 & -0,5 & 0,3 \\ 20,6 & 41,9 & 89,1 & 7,1 & 6,5 & 17,6 & 91 & 22 \\ 843 & 676 & 380 & 733 & 904 & 870 & 794 & 284 \\ 3,88 & 8,35 & 2,01 & 7,51 & 0,19 & 2,60 & 56 & 85 \\ 41,8 & 2,99 & 106 & 8,25 & 0,33 & 40,0 & 1458 & 392 \\ 6,45 & 0,39 & 37,99 & 0,84 & 0,09 & 4,61 & 15,49 & 22,19 \\ 0,279 & 0,307 & 0,336 & 0,392 & 0,176 & 0,480 & 0,295 & 0,190 \\ & & & & & & & \end{array}$

$\begin{array}{rrrrrrrr}0,030 & 0,033 & 0,021 & 0,006 & 0,002 & 0,094 & 0,243 & 0,035 \\ 0,119 & 0,094 & 0,115 & 0,048 & 0,049 & 0,195 & 0,238 & 0,292 \\ 0,024 & 0,018 & 0,012 & 0,010 & 0,022 & 0,024 & 0,019 & 0,198 \\ 0,142 & 0,170 & 0,251 & 0,088 & 0,059 & 0,181 & 0,273 & 1,671 \\ -0,05 & -0,05 & -0,06 & -0,04 & -0,07 & -0,03 & -0,03 & 0,01 \\ 0,1 & 0,8 & 0,3 & 0,7 & 0,2 & -0,1 & 0,6 & 0,6 \\ 2,0 & 1,8 & 2,0 & 1,3 & 1,2 & 1,7 & 2,0 & 0,5\end{array}$




$\begin{array}{rrrrrrrr}552 & 602 & 901 & 317 & 413 & 619 & 761 & 169 \\ 15,17 & 30,48 & 9,66 & 23,16 & 4,12 & 12,19 & 189 & 27 \\ 29,90 & 65,61 & 37,29 & 52,03 & 5,63 & 22,94 & 422 & 51 \\ 4,23 & 8,35 & 2,23 & 6,50 & 0,49 & 2,93 & 52 & 8 \\ 14,95 & 33,49 & 8,09 & 26,70 & 2,00 & 12,06 & 202 & 41 \\ 2,20 & 5,45 & 1,26 & 3,93 & 0,16 & 1,70 & 32 & 12 \\ 2,22 & 2,05 & 1,43 & 1,97 & 1,90 & 2,23 & 4,09 & 3,39 \\ 1,83 & 4,30 & 0,95 & 3,45 & 0,17 & 1,48 & 23,5 & 18,0 \\ 0,211 & 0,466 & 0,108 & 0,395 & 0,021 & 0,145 & 2,80 & 2,91 \\ 1,000 & 2,211 & 0,499 & 1,910 & 0,053 & 0,694 & 13,62 & 18,92 \\ 0,165 & 0,359 & 0,080 & 0,301 & 0,010 & 0,096 & 2,13 & 3,97 \\ 0,256 & 0,630 & 0,204 & 0,607 & 0,009 & 0,186 & 4,23 & 11,25 \\ 0,035 & 0,052 & 0,022 & 0,058 & 0,002 & 0,020 & 0,36 & 1,48 \\ 0,177 & 0,233 & 0,096 & 0,315 & 0,013 & 0,082 & 1,76 & 8,81 \\ 0,015 & 0,029 & 0,007 & 0,030 & 0,002 & 0,012 & 0,17 & 1,41 \\ 1,089 & 0,090 & 2,344 & 0,294 & 0,034 & 1,464 & 33,76 & 13,95 \\ 0,514 & 0,031 & 1,726 & 0,073 & 0,008 & 0,593 & 3,511 & 2,208 \\ 0,202 & 0,565 & 0,130 & 0,152 & 0,282 & 0,870 & 0,763 & 2,716\end{array}$

$\begin{array}{rrrrrrrr}0,026 & 0,035 & 0,044 & 0,039 & 0,016 & 0,015 & 0,175 & 0,122 \\ 4,304 & 4,634 & 5,915 & 3,170 & 3,953 & 4,283 & 7,090 & 13,110 \\ 0,001 & 0,000 & 0,003 & -0,001 & 0,002 & 0,006 & 0,009 & 0,038 \\ 1,617 & 2,510 & 5,199 & 1,321 & 0,035 & 1,153 & 16,709 & 5,279 \\ 0,303 & 0,523 & 0,917 & 0,321 & 0,152 & 0,224 & 2,814 & 1,008\end{array}$


bulk raster bulk raster bulk raster bulk raster bulk raster bulk raster bulk raster bulk raster 25-NWA869<26-NWA869<27-NWA869<28-NWA869<29-NWA869く30-NWA869<31-NWA869<32-NWA869،

\begin{tabular}{|c|c|c|c|c|c|c|c|}
\hline 35,4 & 34,3 & 33,8 & 33,6 & 33,6 & 33,3 & 34,0 & 33,6 \\
\hline 0,28 & 0,31 & 0,36 & 0,36 & 0,12 & 0,20 & 0,84 & 0,49 \\
\hline 0,041 & 0,058 & 0,086 & 0,046 & 0,036 & 0,051 & 0,083 & 0,059 \\
\hline 0,172 & 0,352 & 0,667 & 0,268 & 0,167 & 0,299 & 0,359 & 0,249 \\
\hline 38,31 & 39,24 & 39,49 & 39,97 & 40,12 & 40,46 & 39,25 & 39,96 \\
\hline 0,838 & 0,838 & 0,842 & 0,845 & 0,852 & 0,862 & 0,828 & 0,844 \\
\hline 23,61 & 23,65 & 23,80 & 24,12 & 24,30 & 24,23 & 23,55 & 23,81 \\
\hline 1,05 & 1,04 & 0,73 & 0,50 & 0,71 & 0,45 & 0,62 & 0,60 \\
\hline 0,10 & 0,10 & 0,10 & 0,11 & 0,04 & 0,06 & 0,28 & 0,16 \\
\hline 0,047 & 0,039 & 0,057 & 0,055 & 0,039 & 0,033 & 0,076 & 0,062 \\
\hline 0,18 & 0,04 & 0,06 & 0,09 & 0,04 & 0,09 & 0,11 & 0,13 \\
\hline 3,0 & 3,1 & 3,0 & 3,3 & 3,8 & 3,6 & 3,7 & 3,7 \\
\hline 0,03 & 0,04 & 0,04 & 0,03 & 0,02 & 0,02 & 0,05 & 0,03 \\
\hline 1,6 & 1,6 & 1,8 & 1,3 & 1,4 & 1,6 & 1,4 & 1,7 \\
\hline 0,01 & 0,02 & 0,01 & 0,01 & 0,00 & 0,01 & 0,01 & 0,01 \\
\hline 7,7 & 7,7 & 7,2 & 6,5 & 7,3 & 6,2 & 6,9 & 7,2 \\
\hline 26 & 40 & 62 & 27 & 22 & 27 & 38 & 27 \\
\hline 1174 & 2409 & 4566 & 1831 & 1140 & 2045 & 2456 & 1704 \\
\hline 110 & 114 & 114 & 114 & 114 & 116 & 111 & 112 \\
\hline 308 & 322 & 318 & 318 & 316 & 320 & 308 & 310 \\
\hline 3,4 & 7,8 & 4,3 & 2,9 & 3,9 & 3,3 & 3,1 & 4,0 \\
\hline 110 & 114 & 120 & 113 & 112 & 116 & 115 & 113 \\
\hline 0,61 & 0,75 & 1,10 & 0,64 & 0,46 & 0,63 & 1,10 & 0,78 \\
\hline 1,2 & 1,2 & 1,1 & 1,1 & 1,2 & 1,1 & 1,1 & 1,1 \\
\hline 0,1 & 0,0 & 0,0 & 0,0 & 0,0 & 0,0 & 0,0 & 0,0 \\
\hline 0,2 & 0,2 & 0,1 & 0,1 & 0,1 & 0,0 & 0,0 & 0,1 \\
\hline 1,02 & 1,19 & 2,21 & 0,98 & 0,89 & 1,11 & 0,87 & 0,92 \\
\hline 14 & 15 & 12 & 19 & 8 & 13 & 40 & 25 \\
\hline 1,30 & 0,99 & 0,92 & 0,92 & 0,95 & 0,96 & 0,98 & 1,25 \\
\hline 1,19 & 2,36 & 5,33 & 1,85 & 2,02 & 3,03 & 3,42 & 4,15 \\
\hline 0,14 & 0,40 & 1,00 & 0,25 & 0,14 & 0,47 & 0,62 & 0,55 \\
\hline 0,015 & 0,016 & 0,010 & 0,010 & 0,017 & 0,012 & 0,009 & 0,023 \\
\hline 0,007 & 0,013 & 0,015 & 0,015 & 0,018 & 0,007 & 0,004 & 0,003 \\
\hline 0,001 & 0,002 & 0,002 & 0,002 & 0,002 & 0,001 & 0,000 & 0,000 \\
\hline 0,009 & 0,011 & 0,018 & 0,007 & 0,010 & 0,015 & 0,015 & 0,011 \\
\hline 0,006 & 0,019 & 0,008 & 0,005 & 0,004 & 0,005 & 0,004 & 0,005 \\
\hline 0,029 & 0,027 & 0,022 & 0,020 & 0,025 & 0,023 & 0,020 & 0,019 \\
\hline 0,004 & 0,022 & 0,007 & 0,003 & 0,004 & 0,003 & 0,004 & 0,003 \\
\hline 0,095 & 0,155 & 0,107 & 0,031 & 0,166 & 0,079 & 0,106 & 0,066 \\
\hline 0,00 & 0,01 & 0,06 & 0,00 & 0,00 & 0,00 & 0,00 & 0,01 \\
\hline 0,2 & 0,4 & 0,4 & 0,2 & 0,2 & 0,2 & 0,2 & 0,2 \\
\hline 0,1 & 0,2 & 0,4 & 0,2 & 0,1 & 0,1 & 0,1 & 0,1 \\
\hline
\end{tabular}




$\begin{array}{rrrrrrrr}6 & 5 & 6 & 12 & 4 & 4 & 25 & 15 \\ 1,71 & 0,29 & 0,39 & 1,10 & 0,24 & 1,14 & 1,32 & 1,68 \\ 4,64 & 0,94 & 1,17 & 2,73 & 0,77 & 2,79 & 3,22 & 4,20 \\ 0,60 & 0,14 & 0,16 & 0,34 & 0,11 & 0,34 & 0,40 & 0,52 \\ 2,23 & 0,64 & 0,67 & 1,24 & 0,51 & 1,24 & 1,54 & 1,97 \\ 0,41 & 0,16 & 0,15 & 0,21 & 0,13 & 0,20 & 0,26 & 0,33 \\ 0,05 & 0,04 & 0,03 & 0,05 & 0,02 & 0,03 & 0,10 & 0,07 \\ 0,38 & 0,19 & 0,17 & 0,22 & 0,15 & 0,21 & 0,27 & 0,33 \\ 0,05 & 0,03 & 0,03 & 0,03 & 0,03 & 0,03 & 0,03 & 0,04 \\ 0,28 & 0,19 & 0,17 & 0,18 & 0,17 & 0,18 & 0,19 & 0,25 \\ 0,05 & 0,04 & 0,04 & 0,04 & 0,04 & 0,04 & 0,04 & 0,05 \\ 0,15 & 0,12 & 0,12 & 0,11 & 0,12 & 0,12 & 0,12 & 0,15 \\ 0,02 & 0,02 & 0,02 & 0,02 & 0,02 & 0,02 & 0,02 & 0,02 \\ 0,12 & 0,11 & 0,11 & 0,11 & 0,11 & 0,11 & 0,12 & 0,13 \\ 0,02 & 0,02 & 0,02 & 0,02 & 0,02 & 0,02 & 0,02 & 0,02 \\ 0,037 & 0,067 & 0,132 & 0,056 & 0,071 & 0,087 & 0,125 & 0,139 \\ 0,007 & 0,022 & 0,053 & 0,013 & 0,009 & 0,028 & 0,045 & 0,048 \\ 0,045 & 0,059 & 0,076 & 0,051 & 0,042 & 0,053 & 0,065 & 0,104 \\ 0,001 & 0,001 & 0,001 & 0,001 & 0,001 & 0,001 & 0,001 & 0,003 \\ 0,002 & 0,003 & 0,002 & 0,003 & 0,003 & 0,002 & 0,002 & 0,002 \\ 0,002 & 0,003 & 0,003 & 0,003 & 0,003 & 0,001 & 0,001 & 0,003 \\ 0,000 & 0,004 & 0,001 & 0,003 & 0,006 & 0,003 & 0,000 & 0,001 \\ 0,021 & 0,001 & 0,001 & 0,001 & 0,065 & 0,003 & 0,005 & 0,040 \\ 0,008 & 0,020 & 0,010 & 0,008 & 0,028 & 0,007 & 0,010 & 0,016 \\ 0,368 & 0,595 & 0,375 & 0,389 & 0,282 & 0,318 & 0,493 & 0,611 \\ 0,001 & 0,010 & 0,002 & 0,001 & 0,080 & 0,001 & 0,001 & 0,012 \\ 0,080 & 0,049 & 0,116 & 0,085 & 0,059 & 0,124 & 0,130 & 0,160 \\ 0,066 & 0,083 & 0,057 & 0,052 & 0,474 & 0,077 & 0,063 & 0,095\end{array}$




\begin{tabular}{|c|c|c|c|c|c|c|c|}
\hline \multirow{2}{*}{$\begin{array}{l}\text { bulk raster } \\
\text { 33-NWA8694 }\end{array}$} & & olivine & olivine & olivine & olivine & olivine & \\
\hline & & \multicolumn{6}{|c|}{ 26-Chassigny 27-Chassigny 28-Chassigny 29-Chassigny 30-Chassigny 31-Chassign } \\
\hline & \multicolumn{7}{|c|}{ Major Elements (wt. \%) } \\
\hline 34,7 & $\mathrm{SiO}_{2}$ & 36,5 & 36,2 & 36,5 & 36,3 & 36,5 & 36,4 \\
\hline 0,19 & $\mathrm{Al}_{2} \mathrm{O}_{3}$ & 0,02 & 0,11 & 0,02 & 0,02 & 0,02 & 0,02 \\
\hline 0,064 & $\mathrm{TiO}_{2}$ & 0,021 & 0,035 & 0,017 & 0,017 & 0,018 & 0,020 \\
\hline 0,296 & $\mathrm{Cr}_{2} \mathrm{O}_{3}$ & 0,022 & 0,312 & 0,023 & 0,028 & 0,026 & 0,025 \\
\hline 38,60 & FeOT & 28,82 & 29,07 & 28,53 & 28,64 & 28,84 & 28,77 \\
\hline 0,839 & MnO & 0,571 & 0,574 & 0,566 & 0,564 & 0,568 & 0,572 \\
\hline 23,48 & MgO & 33,88 & 33,48 & 34,12 & 34,19 & 33,82 & 33,95 \\
\hline 1,73 & $\mathrm{CaO}$ & 0,15 & 0,17 & 0,19 & 0,22 & 0,21 & 0,18 \\
\hline 0,05 & $\mathrm{Na}_{2} \mathrm{O}$ & 0,01 & 0,02 & 0,02 & 0,02 & 0,01 & 0,02 \\
\hline 0,025 & $\mathrm{~K}_{2} \mathrm{O}$ & 0,003 & 0,004 & 0,003 & 0,004 & 0,004 & 0,004 \\
\hline \multirow[t]{2}{*}{0,05} & $\mathrm{P}_{2} \mathrm{O}_{5}$ & 0,02 & 0,02 & 0,07 & 0,02 & 0,02 & 0,01 \\
\hline & \multicolumn{7}{|c|}{ Trace elements (ppm) } \\
\hline 3,8 & Li & 3,5 & 3,6 & 5,2 & 4,3 & 4,2 & 4,2 \\
\hline 0,03 & $\mathrm{Be}$ & 0,02 & 0,01 & 0,01 & 0,01 & 0,02 & 0,01 \\
\hline 1,2 & B & 0,5 & 0,6 & 0,9 & 0,6 & 0,6 & 0,7 \\
\hline 0,00 & $S$ & 0,03 & 0,01 & 0,01 & 0,01 & 0,01 & 0,01 \\
\hline 9,7 & Sc & 6,0 & 6,1 & 6,7 & 6,2 & 6,4 & 6,1 \\
\hline 43 & v & 5 & 23 & 5 & 5 & 6 & 6 \\
\hline 2024 & $\mathrm{Cr}$ & 151 & 2133 & 155 & 189 & 175 & 168 \\
\hline 108 & Co & 132 & 134 & 132 & 131 & 133 & 133 \\
\hline 299 & $\mathbf{N i}$ & 509 & 505 & 494 & 490 & 499 & 501 \\
\hline 2,9 & $\mathrm{Cu}$ & 1,0 & 1,0 & 0,8 & 0,4 & 0,4 & 0,5 \\
\hline 110 & $\mathrm{Zn}$ & 69 & 71 & 68 & 69 & 71 & 70 \\
\hline 0,64 & Ga & 0,13 & 0,42 & 0,11 & 0,12 & 0,11 & 0,12 \\
\hline 1,3 & Ge & 1,0 & 1,1 & 1,3 & 1,3 & 1,3 & 1,1 \\
\hline 0,0 & As & 0,1 & 0,0 & 0,0 & 0,0 & 0,0 & 0,1 \\
\hline 0,0 & Se & 0,1 & 0,1 & 0,0 & 0,0 & 0,0 & 0,0 \\
\hline 0,79 & $\mathbf{R b}$ & 0,1 & 0,1 & 0,1 & 0,1 & 0,1 & 0,1 \\
\hline 8 & $\mathrm{Sr}$ & 0,0 & 0,2 & 0,0 & 0,2 & 0,0 & 0,1 \\
\hline 1,61 & $Y$ & 0,3 & 0,4 & 0,3 & 0,3 & 0,3 & 0,3 \\
\hline 3,25 & $\mathrm{Zr}$ & 0,5 & 0,2 & 0,1 & 0,1 & 0,1 & 0,1 \\
\hline 0,29 & $\mathrm{Nb}$ & 0,0 & 0,0 & 0,0 & 0,0 & 0,0 & 0,0 \\
\hline 0,007 & Mo & 0,054 & 0,057 & 0,068 & 0,086 & 0,069 & 0,071 \\
\hline 0,004 & Ru & 0,005 & 0,003 & 0,005 & 0,010 & 0,007 & 0,008 \\
\hline 0,000 & $\mathbf{R h}$ & 0,001 & 0,000 & 0,001 & 0,000 & 0,000 & 0,000 \\
\hline 0,009 & Pd & 0,007 & 0,004 & 0,005 & 0,005 & 0,003 & 0,005 \\
\hline 0,003 & $\mathrm{Ag}$ & 0,006 & 0,028 & 0,003 & 0,002 & 0,001 & 0,005 \\
\hline 0,028 & Cd & 0,089 & 0,077 & 0,067 & 0,075 & 0,090 & 0,090 \\
\hline 0,004 & In & 0,006 & 0,005 & 0,005 & 0,006 & 0,008 & 0,007 \\
\hline 0,212 & Sn & 0,035 & 0,031 & 0,025 & 0,018 & 0,026 & 0,027 \\
\hline 0,00 & Sb & 0,02 & 0,01 & 0,02 & 0,01 & 0,01 & 0,02 \\
\hline 0,1 & $\mathrm{Te}$ & 0,04 & 0,01 & 0,01 & 0,01 & 0,00 & 0,00 \\
\hline 0,1 & Cs & 0,04 & 0,03 & 0,03 & 0,03 & 0,04 & 0,05 \\
\hline
\end{tabular}




$\begin{array}{rlrrrrrr}1 & \text { Ba } & 0 & 0 & 0 & 0 & 0 & 0 \\ 0,46 & \text { La } & 0,007 & 0,027 & 0,028 & 0,030 & 0,009 & 0,057 \\ 1,47 & \text { Ce } & 0,009 & 0,072 & 0,082 & 0,045 & 0,048 & 0,039 \\ 0,24 & \text { Pr } & 0,001 & 0,008 & 0,006 & 0,014 & 0,002 & 0,005 \\ 1,06 & \text { Nd } & 0,006 & 0,027 & 0,019 & 0,042 & 0,006 & 0,021 \\ 0,28 & \text { Sm } & 0,002 & 0,004 & 0,002 & 0,006 & 0,006 & 0,002 \\ 0,05 & \text { Eu } & 0,002 & 0,001 & 0,001 & 0,002 & 0,001 & 0,000 \\ 0,31 & \text { Gd } & 0,008 & 0,015 & 0,010 & 0,012 & 0,012 & 0,010 \\ 0,05 & \text { Tb } & 0,003 & 0,004 & 0,004 & 0,004 & 0,004 & 0,003 \\ 0,33 & \text { Dy } & 0,038 & 0,051 & 0,033 & 0,043 & 0,040 & 0,033 \\ 0,07 & \text { Ho } & 0,012 & 0,014 & 0,013 & 0,013 & 0,013 & 0,012 \\ 0,20 & \text { Er } & 0,052 & 0,058 & 0,050 & 0,048 & 0,047 & 0,048 \\ 0,03 & \text { Tm } & 0,009 & 0,019 & 0,009 & 0,008 & 0,009 & 0,009 \\ 0,16 & \text { Yb } & 0,068 & 0,076 & 0,075 & 0,071 & 0,066 & 0,076 \\ 0,03 & \text { Lu } & 0,014 & 0,013 & 0,014 & 0,013 & 0,015 & 0,014 \\ 0,099 & \text { Hf } & 0,019 & 0,007 & 0,004 & 0,003 & 0,002 & 0,004 \\ 0,024 & \text { Ta } & 0,001 & 0,001 & 0,000 & 0,001 & 0,000 & 0,000 \\ 0,040 & \text { W } & 0,009 & 0,035 & 0,007 & 0,008 & 0,012 & 0,009 \\ 0,001 & \text { Re } & 0,000 & 0,000 & 0,000 & 0,001 & 0,000 & 0,000 \\ 0,001 & \text { Os } & 0,000 & 0,000 & 0,000 & 0,001 & 0,000 & 0,000 \\ 0,001 & \text { Ir } & 0,000 & 0,000 & 0,000 & 0,000 & 0,000 & 0,000 \\ 0,002 & \text { Pt } & -0,001 & 0,001 & 0,001 & 0,000 & 0,000 & 0,000 \\ 0,001 & \text { Au } & 0,001 & 0,002 & 0,001 & 0,001 & 0,000 & 0,001 \\ 0,005 & \text { Tl } & 0,001 & 0,000 & 0,001 & 0,001 & 0,000 & 0,000 \\ 0,207 & \text { Pb } & 0,71 & 0,12 & 0,10 & 0,07 & 0,06 & 0,09 \\ 0,001 & \text { Bi } & 0,003 & 0,002 & 0,003 & 0,002 & 0,002 & 0,002 \\ 0,054 & \text { Th } & 0,001 & 0,002 & 0,000 & 0,000 & 0,000 & 0,000 \\ 0,049 & \text { U } & 0,004 & 0,002 & 0,003 & 0,002 & 0,001 & 0,002\end{array}$


olivine pyroxene pyroxene pyroxene pyroxene pyroxene pyroxene pyroxene 32-Chassigny 33-Chassigny 34-Chassigny 35-Chassigny 36-Chassigny 37-Chassigny 38-Chassigny 39-Chassigny

\begin{tabular}{|c|c|c|c|c|c|c|c|}
\hline 36,4 & 41,6 & 39,2 & 52,0 & 48,1 & 47,5 & 53,1 & 40,6 \\
\hline 0,02 & 0,33 & 0,80 & 1,28 & 1,58 & 9,31 & 0,83 & 2,22 \\
\hline 0,017 & 0,082 & 0,202 & 0,306 & 0,323 & 0,130 & 0,182 & 0,597 \\
\hline 0,028 & 0,401 & 2,384 & 0,760 & 0,638 & 0,204 & 0,343 & 12,9 \\
\hline 28,87 & 24,11 & 23,78 & 9,30 & 11,40 & 12,91 & 15,42 & 19,48 \\
\hline 0,573 & 0,567 & 0,511 & 0,358 & 0,371 & 0,434 & 0,481 & 0,537 \\
\hline 33,81 & 30,61 & 28,55 & 17,25 & 19,00 & 22,55 & 23,12 & 19,02 \\
\hline 0,19 & 2,14 & 4,43 & 18,41 & 17,05 & 4,36 & 6,35 & 4,44 \\
\hline 0,02 & 0,08 & 0,12 & 0,36 & 0,43 & 1,97 & 0,17 & 0,14 \\
\hline 0,004 & 0,008 & 0,010 & 0,005 & 0,020 & 0,623 & 0,029 & 0,015 \\
\hline 0,02 & 0,03 & 0,04 & 0,01 & 1,12 & 0,01 & 0,00 & 0,01 \\
\hline 5,1 & 4,5 & 5,1 & 4,9 & 4,3 & 315,9 & 2,6 & 2,7 \\
\hline 0,01 & 0,05 & 0,08 & 0,04 & 0,14 & 0,96 & 0,17 & 0,10 \\
\hline 0,8 & 1,4 & 1,6 & 1,1 & 1,3 & 9,6 & 4,0 & 1,6 \\
\hline 0,01 & 0,02 & 0,04 & 0,01 & 0,02 & 0,06 & 1,13 & 0,03 \\
\hline 6,0 & 12,4 & 15,9 & 52,5 & 53,5 & 26,8 & 29,3 & 20,1 \\
\hline 6 & 49 & 171 & 196 & 179 & 56 & 108 & 621 \\
\hline 190 & 2742 & 16313 & 5198 & 4363 & 1398 & 2347 & 88296 \\
\hline 134 & 110 & 109 & 32 & 44 & 44 & 49 & 77 \\
\hline 502 & 364 & 386 & 102 & 150 & 221 & 140 & 133 \\
\hline 0,3 & 12,8 & 5,1 & 2,6 & 16,4 & 8,4 & 31,5 & 8,0 \\
\hline 72 & 64 & 108 & 20 & 26 & 87 & 44 & 178 \\
\hline 0,11 & 0,76 & 3,42 & 2,51 & 3,31 & 4,86 & 1,87 & 9,75 \\
\hline 1,1 & 1,4 & 1,6 & 1,9 & 1,7 & 0,6 & 1,7 & 1,5 \\
\hline 0,0 & 0,1 & 0,2 & 0,0 & 0,0 & 0,3 & 0,1 & 0,0 \\
\hline 0,0 & 0,0 & 0,0 & $-0,1$ & 0,0 & 1,7 & 0,7 & 0,0 \\
\hline 0,2 & 0,2 & 0,4 & 0,2 & 0,4 & 30,0 & 1,6 & 0,6 \\
\hline 0,0 & 4,0 & 8,2 & 50,3 & 104,7 & 3,0 & 6,4 & 6,0 \\
\hline 0,3 & 1,7 & 2,3 & 11,0 & 17,6 & 4,5 & 5,7 & 2,5 \\
\hline 0,2 & 1,4 & 2,0 & 7,5 & 16,9 & 14,0 & 12,1 & 2,0 \\
\hline 0,0 & 0,1 & 0,4 & 0,1 & 0,3 & 0,4 & 1,0 & 0,3 \\
\hline 0,098 & 0,081 & 0,078 & 0,063 & 0,056 & 3,031 & 0,065 & 0,085 \\
\hline 0,005 & 0,005 & 0,008 & 0,005 & 0,006 & 0,310 & 0,007 & 0,019 \\
\hline 0,001 & 0,001 & 0,001 & 0,000 & 0,001 & 0,071 & 0,002 & 0,001 \\
\hline 0,007 & 0,015 & 0,011 & 0,021 & 0,026 & 0,249 & 0,020 & 0,012 \\
\hline 0,007 & 0,243 & 0,066 & 0,015 & 0,010 & 0,167 & 0,081 & 0,029 \\
\hline 0,118 & 0,272 & 0,081 & 0,088 & 0,083 & 0,899 & 0,115 & 0,145 \\
\hline 0,006 & 0,011 & 0,007 & 0,016 & 0,016 & 0,140 & 0,011 & 0,010 \\
\hline 0,033 & 1,543 & 0,111 & 0,030 & 0,045 & 0,139 & 0,088 & 0,482 \\
\hline 0,01 & 0,04 & 0,14 & 0,02 & 0,02 & $-0,10$ & 0,01 & 0,02 \\
\hline 0,01 & 0,01 & 0,09 & 0,03 & 0,04 & 0,48 & 8,41 & 0,06 \\
\hline 0,04 & 0,06 & 0,10 & 0,08 & 0,11 & 11,18 & 0,22 & 0,16 \\
\hline
\end{tabular}




$\begin{array}{rrrrrrrr}0 & 0 & 0 & 0 & 7 & 1 & 1 & 1 \\ 0,012 & 0,233 & 0,295 & 1,451 & 15,209 & 1,001 & 0,955 & 0,428 \\ 0,058 & 0,910 & 1,219 & 6,393 & 38,202 & 3,142 & 3,626 & 1,425 \\ 0,010 & 0,169 & 0,235 & 1,414 & 5,744 & 0,550 & 0,686 & 0,249 \\ 0,027 & 0,961 & 1,289 & 8,408 & 26,417 & 2,304 & 3,540 & 1,312 \\ 0,000 & 0,282 & 0,398 & 2,524 & 5,664 & 1,024 & 0,978 & 0,378 \\ 0,001 & 0,072 & 0,101 & 0,596 & 1,129 & 0,165 & 0,202 & 0,101 \\ 0,012 & 0,320 & 0,458 & 2,799 & 5,395 & 0,919 & 1,132 & 0,439 \\ 0,003 & 0,052 & 0,075 & 0,436 & 0,769 & 0,105 & 0,182 & 0,074 \\ 0,037 & 0,347 & 0,472 & 2,496 & 4,209 & 0,977 & 1,157 & 0,496 \\ 0,012 & 0,072 & 0,092 & 0,456 & 0,737 & 0,203 & 0,217 & 0,099 \\ 0,048 & 0,203 & 0,245 & 1,116 & 1,713 & 0,606 & 0,583 & 0,295 \\ 0,009 & 0,026 & 0,033 & 0,127 & 0,183 & 0,085 & 0,073 & 0,036 \\ 0,064 & 0,159 & 0,188 & 0,676 & 0,926 & 0,338 & 0,398 & 0,224 \\ 0,013 & 0,025 & 0,029 & 0,088 & 0,113 & 0,034 & 0,055 & 0,036 \\ 0,005 & 0,050 & 0,074 & 0,390 & 0,826 & 0,446 & 0,365 & 0,075 \\ 0,000 & 0,004 & 0,015 & 0,004 & 0,022 & 0,036 & 0,076 & 0,012 \\ 0,009 & 0,018 & 0,042 & 0,008 & 0,029 & 0,083 & 0,070 & 0,058 \\ 0,000 & 0,000 & 0,001 & 0,000 & 0,000 & -0,009 & 0,000 & 0,001 \\ 0,000 & 0,001 & 0,001 & 0,000 & 0,001 & 0,071 & 0,000 & 0,000 \\ 0,000 & 0,000 & 0,001 & 0,000 & 0,000 & -0,001 & 0,001 & 0,000 \\ 0,001 & -0,001 & 0,000 & 0,001 & 0,000 & -0,025 & 0,001 & 0,002 \\ 0,000 & 0,002 & 0,007 & 0,001 & 0,001 & 0,217 & 0,003 & 0,003 \\ 0,001 & 0,002 & 0,002 & 0,000 & 0,001 & 0,008 & 0,082 & 0,004 \\ 0,08 & 4,40 & 24,47 & 0,24 & 0,59 & 5,59 & 12,80 & 0,53 \\ 0,003 & 0,004 & 0,008 & 0,002 & 0,002 & 0,078 & 0,012 & 0,002 \\ 0,000 & 0,012 & 0,030 & 0,008 & 0,695 & 0,082 & 0,106 & 0,018 \\ 0,002 & 0,008 & 0,013 & 0,005 & 0,161 & 0,010 & 0,019 & 0,009\end{array}$


pyroxene? melt/plag mesostasis mesostasis olivine? olivine? olivine? chromite 40-Chassigny 41-Chassigny 42-Chassigny 43-Chassigny 44-Chassigny 45-Chassigny 46-Chassigny 47-Chassigny

\begin{tabular}{|c|c|c|c|c|c|c|c|}
\hline 41,6 & 46,1 & 53,6 & 58,1 & 36,6 & 37,2 & 37,3 & 0,1 \\
\hline 0,21 & 29,25 & 16,15 & 11,50 & 0,36 & 0,17 & 0,03 & 8,64 \\
\hline 0,061 & 0,044 & 0,360 & 0,538 & 0,024 & 0,020 & 0,016 & 1,975 \\
\hline 0,092 & 0,007 & 0,035 & 0,059 & 0,021 & 0,021 & 0,028 & 50,3 \\
\hline 25,22 & 3,86 & 6,24 & 5,32 & 27,82 & 27,99 & 27,84 & 33,60 \\
\hline 0,561 & 0,084 & 0,186 & 0,186 & 0,563 & 0,565 & 0,558 & 0,504 \\
\hline 31,65 & 4,02 & 8,19 & 8,60 & 33,97 & 33,43 & 33,66 & 4,11 \\
\hline 0,59 & 14,21 & 9,61 & 9,00 & 0,28 & 0,25 & 0,25 & 0,14 \\
\hline 0,03 & 2,03 & 4,25 & 5,70 & 0,30 & 0,25 & 0,24 & 0,48 \\
\hline 0,009 & 0,333 & 0,319 & 0,240 & 0,078 & 0,064 & 0,074 & 0,154 \\
\hline 0,01 & 0,07 & 1,05 & 0,74 & 0,03 & 0,02 & 0,03 & 0,01 \\
\hline 4,1 & 71,9 & 57,1 & 43,4 & 38,0 & 35,2 & 40,6 & 71,9 \\
\hline 0,07 & 1,41 & 2,42 & 2,89 & 0,11 & 0,15 & 0,22 & 0,24 \\
\hline 0,9 & 2,5 & 10,2 & 14,7 & 1,6 & 1,5 & 0,9 & 2,1 \\
\hline 0,02 & 0,01 & 0,06 & 0,06 & 0,02 & 0,01 & 0,01 & 0,01 \\
\hline 9,1 & 3,4 & 11,4 & 17,7 & 6,1 & 5,7 & 6,2 & 4,6 \\
\hline 23 & 2 & 16 & 28 & 5 & 5 & 6 & 2066 \\
\hline 629 & 46 & 243 & 404 & 146 & 143 & 189 & 343976 \\
\hline 110 & 16 & 22 & 17 & 132 & 127 & 127 & 183 \\
\hline 394 & 89 & 99 & 76 & 490 & 588 & 503 & 179 \\
\hline 0,6 & 3,6 & 6,6 & 7,5 & 20,0 & 2,6 & 0,8 & 9,9 \\
\hline 66 & 16 & 24 & 18 & 88 & 82 & 81 & 1274 \\
\hline 0,51 & 16,45 & 10,12 & 7,69 & 0,37 & 0,31 & 0,20 & 38,72 \\
\hline 1,2 & 1,3 & 2,3 & 2,5 & 0,9 & 1,1 & 1,1 & 0,9 \\
\hline 0,0 & $-0,1$ & 0,1 & 0,0 & 0,1 & 0,1 & 0,0 & 0,0 \\
\hline 0,0 & $-0,2$ & $-0,3$ & $-0,5$ & $-0,1$ & 0,1 & $-0,2$ & $-0,3$ \\
\hline 0,4 & 10,7 & 7,4 & 6,6 & 3,8 & 3,1 & 3,7 & 8,1 \\
\hline 0,1 & 1592,8 & 751,5 & 182,5 & 9,9 & 6,9 & 0,1 & 0,3 \\
\hline 0,8 & 1,0 & 21,4 & 24,9 & 0,3 & 0,3 & 0,2 & 0,0 \\
\hline 1,0 & 1,5 & 56,4 & 103,8 & 0,7 & 0,4 & 0,1 & 3,2 \\
\hline 0,1 & 0,2 & 5,5 & 7,7 & 0,1 & 0,0 & 0,0 & 1,0 \\
\hline 0,089 & 0,608 & 0,434 & 0,315 & 0,353 & 0,329 & 0,397 & 0,685 \\
\hline 0,005 & 0,051 & 0,053 & 0,035 & 0,043 & 0,059 & 0,041 & 0,263 \\
\hline 0,001 & 0,014 & 0,005 & 0,011 & 0,008 & 0,001 & $-0,001$ & 0,006 \\
\hline 0,007 & 0,053 & 0,132 & 0,157 & 0,020 & 0,021 & 0,023 & 0,042 \\
\hline 0,009 & 0,094 & 0,414 & 0,106 & 1,852 & 0,088 & 0,010 & 0,062 \\
\hline 0,104 & 0,170 & 0,200 & 0,154 & 0,450 & 0,080 & 0,179 & 0,227 \\
\hline 0,009 & 0,023 & 0,058 & 0,051 & 0,060 & 0,057 & 0,049 & 0,105 \\
\hline 0,028 & 0,055 & 0,155 & 0,171 & 2,716 & 0,068 & 0,052 & 0,102 \\
\hline 0,02 & 0,00 & 0,10 & 0,14 & 0,02 & 0,00 & $-0,01$ & 0,00 \\
\hline 0,01 & 0,18 & 0,15 & 0,11 & 0,11 & 0,35 & $-0,01$ & 0,23 \\
\hline 0,17 & 3,12 & 2,46 & 1,85 & 1,41 & 1,16 & 1,39 & 3,08 \\
\hline
\end{tabular}




$\begin{array}{rrrrrrrr}0 & 99 & 254 & 42 & 1 & 1 & 0 & 0 \\ 0,080 & 6,736 & 22,565 & 14,492 & 0,261 & 0,149 & 0,032 & 0,071 \\ 0,100 & 11,705 & 49,118 & 36,955 & 0,768 & 0,419 & 0,185 & 0,198 \\ 0,026 & 1,221 & 7,237 & 6,010 & 0,100 & 0,045 & 0,009 & 0,013 \\ 0,107 & 4,403 & 28,304 & 26,060 & 0,327 & 0,170 & 0,056 & 0,075 \\ 0,039 & 0,607 & 6,147 & 6,074 & 0,048 & 0,027 & 0,008 & -0,006 \\ 0,012 & 3,197 & 2,253 & 1,391 & 0,027 & 0,026 & 0,008 & 0,011 \\ 0,069 & 0,562 & 5,889 & 6,318 & 0,065 & 0,038 & 0,008 & 0,024 \\ 0,015 & 0,071 & 0,896 & 1,016 & 0,010 & 0,007 & 0,000 & 0,005 \\ 0,143 & 0,275 & 4,988 & 5,635 & 0,038 & 0,061 & 0,013 & 0,004 \\ 0,032 & 0,056 & 0,839 & 1,055 & 0,017 & 0,011 & 0,014 & -0,001 \\ 0,111 & 0,089 & 1,887 & 2,413 & 0,029 & 0,031 & 0,039 & 0,002 \\ 0,018 & 0,007 & 0,203 & 0,261 & 0,007 & 0,005 & 0,006 & 0,003 \\ 0,121 & 0,062 & 0,900 & 1,210 & 0,063 & 0,067 & 0,064 & -0,007 \\ 0,019 & 0,009 & 0,108 & 0,158 & 0,015 & 0,014 & 0,015 & 0,002 \\ 0,034 & 0,033 & 1,578 & 2,948 & 0,030 & 0,010 & 0,003 & 0,122 \\ 0,002 & 0,017 & 0,443 & 0,534 & 0,006 & 0,004 & 0,000 & 0,037 \\ 0,027 & 0,051 & 0,723 & 0,962 & 0,028 & 0,025 & 0,006 & 0,044 \\ 0,000 & -0,003 & 0,001 & -0,002 & 0,005 & -0,001 & 0,000 & 0,005 \\ 0,000 & -0,004 & 0,005 & 0,001 & -0,002 & -0,004 & 0,007 & -0,008 \\ 0,000 & 0,003 & 0,000 & 0,000 & 0,001 & 0,000 & 0,000 & 0,000 \\ 0,000 & -0,008 & 0,002 & 0,006 & -0,005 & -0,001 & 0,002 & -0,012 \\ 0,000 & 0,007 & 0,013 & 0,007 & 0,006 & -0,001 & -0,001 & -0,006 \\ 0,001 & 0,012 & 0,017 & 0,036 & 0,003 & 0,001 & 0,000 & 0,003 \\ 0,15 & 1,89 & 2,27 & 2,10 & 0,55 & 0,26 & 0,03 & 1,30 \\ 0,002 & 0,006 & 0,020 & 0,003 & 0,015 & 0,004 & 0,001 & 0,001 \\ 0,013 & 0,050 & 1,460 & 1,535 & 0,018 & 0,007 & 0,000 & 0,004 \\ 0,003 & 0,035 & 0,367 & 0,355 & 0,007 & 0,005 & 0,000 & 0,005\end{array}$


? mesostasis mesostasis chromite mesostasis 48-Chassigny 49-Chassigny 50-Chassigny 51-Chassigny 52-Chassigny

$\begin{array}{rrrrr}33,0 & 53,8 & 50,4 & 3,3 & 55,8 \\ 12,65 & 12,11 & 7,26 & 7,74 & 19,72 \\ 1,276 & 0,718 & 0,845 & 1,765 & 0,047 \\ 0,297 & 0,124 & 0,135 & 47,5 & 0,021 \\ 23,45 & 11,88 & 14,85 & 32,29 & 5,81 \\ 0,525 & 0,209 & 0,353 & 0,509 & 0,114 \\ 13,67 & 11,19 & 19,01 & 6,33 & 6,88 \\ 11,10 & 2,43 & 3,25 & 0,06 & 4,04 \\ 2,72 & 6,33 & 2,44 & 0,36 & 6,57 \\ 0,556 & 0,741 & 1,261 & 0,118 & 1,032 \\ 0,78 & 0,46 & 0,17 & 0,01 & 0,02 \\ & & & & \\ 2,1 & 35,1 & 5,4 & 46,5 & 14,4 \\ 0,34 & 3,76 & 1,81 & 0,33 & 0,55 \\ 5,4 & 20,2 & 8,5 & 1,3 & 2,2 \\ 0,09 & 2,71 & 0,22 & 0,01 & 0,02 \\ 28,1 & 11,8 & 14,7 & 5,4 & 2,9 \\ 80 & 49 & 54 & 1971 & 2 \\ 2035 & 849 & 926 & 325231 & 144 \\ 67 & 112 & 64 & 177 & 27 \\ 568 & 1358 & 299 & 200 & 114 \\ 10,8 & 559,1 & 30,0 & 2,7 & 3,5 \\ 56 & 37 & 44 & 885 & 21 \\ 20,55 & 5,04 & 4,45 & 30,07 & 10,70 \\ 2,3 & 1,9 & 2,7 & 0,8 & 0,7 \\ 0,2 & 0,1 & 0,1 & 0,0 & 0,1 \\ 0,4 & 6,9 & 0,5 & -0,3 & 0,1 \\ 22,3 & 21,4 & 28,4 & 6,5 & 10,7 \\ 282,8 & 360,9 & 246,0 & 0,6 & 776,4 \\ 84,5 & 13,5 & 11,7 & 0,1 & 0,1 \\ 389,4 & 62,1 & 45,2 & 2,7 & 0,3 \\ 22,1 & 33,9 & 23,8 & 0,7 & 0,1 \\ 0,194 & 0,968 & 0,200 & 0,726 & 0,144 \\ 0,034 & 0,228 & 0,033 & 0,247 & 0,035 \\ 0,010 & 0,071 & 0,007 & 0,003 & 0,005 \\ 0,173 & 0,171 & 0,072 & 0,022 & 0,016 \\ 0,035 & 0,712 & 0,089 & 0,067 & 0,153 \\ 0,314 & 0,193 & 0,116 & 0,161 & 0,238 \\ 0,198 & 0,042 & 0,017 & 0,041 & 0,020 \\ 1,828 & 0,681 & 0,478 & 0,071 & 0,152 \\ 0,01 & 0,02 & 0,05 & 0,04 & 0,04 \\ 0,63 & 0,20 & 0,05 & 0,28 & 0,05 \\ 0,45 & 4,42 & 1,75 & 2,32 & 0,75\end{array}$




$\begin{array}{rrrrr}170 & 403 & 203 & 2 & 478 \\ 26,696 & 10,729 & 3,596 & 0,051 & 3,615 \\ 51,142 & 26,480 & 11,201 & 0,493 & 4,674 \\ 7,977 & 3,716 & 1,721 & 0,060 & 0,397 \\ 40,694 & 16,124 & 8,273 & 0,012 & 0,991 \\ 12,095 & 3,868 & 2,442 & 0,013 & 0,078 \\ 3,397 & 1,149 & 0,808 & 0,016 & 1,639 \\ 18,020 & 3,728 & 2,680 & 0,018 & 0,043 \\ 2,911 & 0,558 & 0,441 & 0,001 & 0,005 \\ 18,924 & 3,065 & 2,563 & -0,001 & 0,010 \\ 3,971 & 0,511 & 0,451 & 0,001 & 0,004 \\ 11,226 & 1,149 & 1,116 & 0,021 & 0,012 \\ 1,479 & 0,124 & 0,122 & 0,001 & 0,001 \\ 8,827 & 0,623 & 0,658 & 0,007 & 0,013 \\ 1,413 & 0,073 & 0,075 & 0,000 & 0,003 \\ 13,981 & 1,513 & 1,372 & 0,082 & 0,009 \\ 2,177 & 1,543 & 1,012 & 0,021 & 0,009 \\ 3,653 & 1,411 & 0,745 & 0,015 & 0,022 \\ 0,002 & 0,009 & 0,001 & 0,011 & 0,000 \\ 0,037 & 0,003 & 0,000 & 0,003 & 0,002 \\ 0,039 & 0,000 & 0,000 & 0,003 & 0,000 \\ 0,033 & 0,207 & 0,033 & 0,001 & -0,004 \\ 0,012 & 0,017 & 0,003 & -0,007 & 0,605 \\ 0,119 & 0,031 & 0,027 & 0,007 & 0,009 \\ 13,45 & 5,05 & 5,02 & 3,52 & 4,92 \\ 0,038 & 0,011 & 0,005 & 0,003 & 0,031 \\ 5,289 & 1,269 & 0,577 & 0,004 & 0,009 \\ 1,030 & 0,337 & 0,163 & 0,009 & 0,009\end{array}$


Modal \% NWA2737 Chassigny NWA8694

\begin{tabular}{cccc}
\hline Olivine & 87,9 & 89,6 & 85,3 \\
Chromite & 3,5 & 4,6 & 0,8 \\
Pyroxene & 6,7 & 4,1 & 11,6 \\
Glass/Fsp & 3,2 & 1,6 & 2,4 \\
Phosphate & 0,2 & 0,2 & 0,14 \\
Carbonate & 0,9 & - & - \\
\hline
\end{tabular}


Table 1 Chassignite modal abundances

\begin{tabular}{lrrr}
\multicolumn{1}{c}{ Modal \% } & NWA $2737^{\mathrm{a}}$ & Chassigny $^{\mathrm{b}}$ & NWA 8694 \\
\hline Olivine & 87.9 & 89.6 & 85.3 \\
Chromite & 3.5 & 4.6 & 0.8 \\
Pyroxenes & 6.7 & 4.1 & 11.6 \\
Glass/Fsp & 3.2 & 1.6 & 2.4 \\
Phosphate & 0.2 & 0.2 & $* 0.14$ \\
Carbonate & 0.9 & & - \\
\hline
\end{tabular}

${ }^{a}$ Average in Treiman et al. (2007). ${ }^{\mathrm{b}}$ Floran et al. (1978).

*Calculated from P abundance. 
Table 2a. Selected analyses of olivine, chromite, biotite and amphibole.

\begin{tabular}{|c|c|c|c|c|c|c|c|c|c|c|c|c|c|}
\hline & $\mathrm{SiO} 2$ & $\mathrm{Al} 2 \mathrm{O} 3$ & $\mathrm{TiO} 2$ & $\mathrm{Cr} 2 \mathrm{O} 3$ & $\mathrm{FeO}$ & $\mathrm{MnO}$ & $\mathrm{MgO}$ & $\mathrm{CaO}$ & $\mathrm{Na} 2 \mathrm{O}$ & Total & Fo & $\mathrm{Fa}$ & \\
\hline \multicolumn{14}{|l|}{ NWA 8694} \\
\hline $107 / 59$ & 35.31 & 0.02 & 0.06 & bd & 38.71 & 0.80 & 25.75 & 0.09 & 0.01 & 100.63 & 54.25 & 45.75 & \\
\hline 94 & 35.74 & 0.01 & 0.06 & 0.06 & 38.81 & 0.76 & 24.97 & 0.28 & bd & 100.72 & 53.42 & 46.58 & \\
\hline $97 / 62$ & 35.74 & 0.02 & 0.04 & 0.04 & 38.99 & 0.78 & 24.85 & 0.12 & 0.02 & 100.61 & 53.19 & 46.81 & \\
\hline $88 / 14$ & 35.08 & 0.01 & 0.03 & 0.06 & 38.89 & 0.76 & 24.59 & 0.13 & bd & 99.66 & 52.99 & 47.01 & \\
\hline LA mean & 35.21 & 0.02 & 0.03 & 0.05 & 38.26 & 0.84 & 25.37 & 0.22 & 0.02 & 100.06 & 54.09 & 45.91 & \\
\hline \multicolumn{14}{|l|}{ Chassigny } \\
\hline 26 & 38.14 & 0.03 & 0.03 & 0.04 & 28.04 & 0.53 & 34.05 & 0.13 & 0.00 & 101.08 & 68.40 & 31.60 & \\
\hline 22 & 37.37 & 0.04 & 0.04 & 0.03 & 27.91 & 0.53 & 33.54 & 0.14 & 0.01 & 99.75 & 68.18 & 31.82 & \\
\hline 23 & 37.55 & 0.03 & 0.00 & 0.02 & 28.56 & 0.54 & 33.98 & 0.21 & 0.01 & 101.07 & 67.96 & 32.04 & \\
\hline 03 & 37.62 & 0.02 & 0.01 & 0.03 & 28.69 & 0.56 & 33.63 & 0.14 & bd & 100.76 & 67.64 & 32.36 & \\
\hline LA mean & 36.39 & 0.03 & 0.02 & 0.07 & 28.79 & 0.57 & 33.89 & 0.19 & 0.02 & 99.97 & 67.72 & 32.28 & \\
\hline \multicolumn{14}{|l|}{ NWA 2737} \\
\hline 8184 & 39.16 & 0.02 & 0.00 & 0.04 & 19.68 & 0.41 & 41.16 & 0.12 & bd & 100.65 & 78.84 & 21.16 & \\
\hline 8279 & 39.24 & 0.04 & 0.01 & 0.04 & 20.08 & 0.55 & 40.56 & 0.15 & bd & 100.68 & 78.28 & 21.72 & \\
\hline 771 & 39.12 & 0.03 & 0.03 & 0.05 & 20.45 & 0.41 & 40.58 & 0.13 & bd & 100.83 & 77.97 & 22.03 & \\
\hline 8226 & 39.12 & 0.05 & 0.02 & 0.02 & 20.73 & 0.52 & 40.22 & 0.14 & bd & 100.83 & 77.58 & 22.42 & \\
\hline NWA 8694 & chromit & & & & & & & & & & & & \\
\hline 15 & 0.07 & 5.59 & 1.66 & 52.93 & 34.98 & bd & 2.45 & bd & bd & 97.67 & & & \\
\hline 15nuit & 0.06 & 8.65 & 2.95 & 49.05 & 33.39 & bd & 0.82 & bd & bd & 96.28 & & & \\
\hline 100 & 0.09 & 7.74 & 3.75 & 44.98 & 38.57 & bd & 2.47 & bd & bd & 98.84 & & & \\
\hline 28 & 0.14 & 9.83 & 4.28 & 41.06 & 40.42 & bd & 1.69 & bd & bd & 97.40 & & & \\
\hline \multicolumn{14}{|c|}{ Chassigny chromite } \\
\hline 6 & 0.08 & 6.10 & 1.32 & 55.31 & 31.77 & 0.00 & 4.09 & bd & bd & 99.06 & & & \\
\hline 12 & 0.04 & 8.14 & 2.14 & 50.88 & 32.47 & 0.00 & 3.65 & bd & bd & 97.66 & & & \\
\hline 7 & 0.05 & 10.16 & 3.49 & 45.70 & 35.17 & 0.00 & 3.54 & bd & bd & 98.58 & & & \\
\hline \multicolumn{14}{|l|}{ NWA 2737} \\
\hline 70 & 0.03 & 6.45 & 1.18 & 57.85 & 28.73 & bd & 5.70 & bd & bd & 99.99 & & & \\
\hline 9936 & 0.02 & 6.97 & 1.34 & 55.90 & 29.84 & bd & 5.83 & bd & bd & 99.94 & & & \\
\hline 9943 & 0.02 & 7.60 & 1.56 & 53.86 & 30.80 & bd & 6.04 & bd & bd & 100.04 & & & \\
\hline 65 & 0.07 & 10.27 & 1.38 & 51.54 & 31.32 & bd & 5.07 & bd & bd & 99.70 & & & \\
\hline 98 & 0.01 & 11.82 & 2.44 & 46.31 & 33.87 & bd & 5.10 & bd & bd & 99.61 & & & \\
\hline NWA 8694 & $\mathrm{SiO} 2$ & $\mathrm{Al} 2 \mathrm{O} 3$ & $\mathrm{TiO} 2$ & $\mathrm{Cr} 2 \mathrm{O} 3$ & $\mathrm{FeO}$ & $\mathrm{MnO}$ & $\mathrm{MgO}$ & $\mathrm{CaO}$ & $\mathrm{Na} 2 \mathrm{O}$ & $\mathrm{K} 2 \mathrm{O}$ & $\mathrm{F}$ & $\mathrm{Cl}$ & Total* \\
\hline inst biotite & 40.11 & 12.12 & 0.77 & 0.26 & 11.21 & 0.09 & 20.33 & 0.13 & 0.16 & 8.70 & 0.99 & 0.82 & 95.75 \\
\hline M.I. biotite & 39.59 & 13.25 & 0.16 & 0.02 & 11.54 & 0.12 & 20.02 & 0.09 & 0.45 & 8.50 & 0.26 & 0.17 & 94.27 \\
\hline M.I. amphibole & 40.07 & 15.63 & 3.12 & 0.09 & 13.40 & 0.28 & 10.35 & 11.35 & 2.91 & 0.23 & 0.66 & 0.42 & 98.54 \\
\hline
\end{tabular}

*Corrected for $\mathrm{O}=\mathrm{F}, \mathrm{Cl}: 95.15,94.12, \&$ 98.17. LA = LA-ICP-MS, inst = interstitial and M.I. = melt inclusion. 
Table 2b. Selected analyses of interstitial and melt-inclusion pyroxene.

\begin{tabular}{|c|c|c|c|c|c|c|c|c|c|c|c|c|c|}
\hline & $\mathrm{SiO} 2$ & $\mathrm{Al} 2 \mathrm{O} 3$ & $\mathrm{TiO} 2$ & $\mathrm{Cr} 2 \mathrm{O} 3$ & $\mathrm{FeO}$ & $\mathrm{MnO}$ & $\mathrm{MgO}$ & $\mathrm{CaO}$ & $\mathrm{Na} 2 \mathrm{O}$ & Total & En & Fs & Wo \\
\hline \multicolumn{14}{|c|}{ NWA 8694} \\
\hline 51 & 52.92 & 0.80 & 0.20 & 0.22 & 22.93 & 0.70 & 20.44 & 1.44 & 0.01 & 99.72 & 59.52 & 37.46 & 3.02 \\
\hline 112 & 52.74 & 0.45 & 0.31 & 0.16 & 21.63 & 0.79 & 19.10 & 4.61 & 0.07 & 99.96 & 55.29 & 35.12 & 9.60 \\
\hline 36 & 52.85 & 1.87 & 0.40 & 0.68 & 12.83 & 0.51 & 13.99 & 17.71 & 0.33 & 101.20 & 41.24 & 21.23 & 37.53 \\
\hline 71 & 52.74 & 0.46 & 0.33 & 0.31 & 10.51 & 0.44 & 14.41 & 19.64 & 0.28 & 99.05 & 41.86 & 17.13 & 41.01 \\
\hline LA mean & 52.52 & 0.67 & 0.16 & 0.50 & 22.17 & 0.77 & 18.93 & 4.63 & 0.13 & 100.50 & 54.55 & 35.86 & 9.58 \\
\hline 77 M.I. & 51.48 & 3.81 & 0.39 & 0.18 & 24.48 & 0.70 & 18.88 & 1.15 & 0.03 & 101.22 & 56.45 & 41.07 & 2.48 \\
\hline \multicolumn{14}{|c|}{ Chassigny } \\
\hline 60 & 55.23 & 0.29 & 0.13 & 0.27 & 17.72 & 0.57 & 24.03 & 2.29 & 0.02 & 100.58 & 67.47 & 27.90 & 4.63 \\
\hline 51 & 55.26 & 0.71 & 0.20 & 0.48 & 15.52 & 0.55 & 22.47 & 6.19 & 0.15 & 101.52 & 63.08 & 24.44 & 12.49 \\
\hline LA $38 \mathrm{Ch}$ & 53.07 & 0.83 & 0.18 & 0.34 & 15.42 & 0.48 & 23.12 & 6.35 & 0.17 & 100.0 & 63.63 & 23.81 & 12.56 \\
\hline 53 & 53.47 & 1.09 & 0.26 & 0.78 & 9.40 & 0.28 & 16.42 & 17.96 & 0.24 & 99.91 & 47.44 & 15.25 & 37.31 \\
\hline 55 & 54.00 & 1.45 & 0.40 & 0.84 & 8.82 & 0.28 & 16.11 & 19.16 & 0.32 & 101.39 & 46.25 & 14.21 & 39.54 \\
\hline LA $35 \mathrm{Ch}$ & 51.96 & 1.28 & 0.31 & 0.76 & 9.30 & 0.36 & 17.25 & 18.41 & 0.36 & 100.0 & 48.32 & 14.61 & 37.07 \\
\hline \multicolumn{14}{|c|}{ NWA 2737} \\
\hline 141 & 56.43 & 0.38 & 0.40 & 0.19 & 12.29 & 0.42 & 29.01 & 1.53 & 0.04 & 100.82 & 78.40 & 18.62 & 2.98 \\
\hline $99 / 51$ & 54.43 & 1.16 & 0.10 & 0.47 & 12.23 & 0.38 & 27.70 & 2.86 & 0.04 & 99.40 & 75.66 & 18.74 & 5.60 \\
\hline 58 & 55.86 & 0.60 & 0.11 & 0.68 & 11.01 & 0.41 & 25.38 & 6.53 & 0.25 & 100.84 & 70.01 & 17.02 & 12.97 \\
\hline $145 / 45$ & 54.25 & 0.92 & 0.26 & 0.90 & 6.90 & 0.27 & 18.27 & 18.02 & 0.32 & 100.11 & 52.07 & 11.04 & 36.89 \\
\hline $145 / 49$ & 53.82 & 1.04 & 0.30 & 0.98 & 6.32 & 0.20 & 17.40 & 19.77 & 0.37 & 100.23 & 49.50 & 10.07 & 40.43 \\
\hline
\end{tabular}

LA = LA-ICP-MS; M.I. =melt inclusion. 
Table 3. Selected analyses of feldspars.

\begin{tabular}{|c|c|c|c|c|c|c|c|c|c|c|c|}
\hline & \multicolumn{4}{|c|}{ NWA 8694} & \multicolumn{4}{|c|}{ Chassigny } & \multicolumn{3}{|c|}{ NWA 2737} \\
\hline $\mathrm{SiO} 2$ & 60.39 & 63.42 & 63.76 & 64.67 & 62.72 & 63.92 & 63.37 & 63.15 & 66.09 & 65.40 & 68.11 \\
\hline $\mathrm{Al} 2 \mathrm{O} 3$ & 23.38 & 23.04 & 21.54 & 19.16 & 22.33 & 22.11 & 21.51 & 21.05 & 21.06 & 20.96 & 20.05 \\
\hline $\mathrm{FeO}$ & 0.53 & 0.34 & 0.37 & 0.47 & 0.57 & 0.42 & 0.40 & 0.35 & 0.16 & 0.21 & 0.11 \\
\hline $\mathrm{MgO}$ & 0.01 & 0.06 & 0.09 & 0.01 & 0.04 & 0.02 & 0.02 & 0.03 & 0.06 & $b d$ & $b d$ \\
\hline $\mathrm{CaO}$ & 5.56 & 3.90 & 2.75 & 0.23 & 3.43 & 3.57 & 2.98 & 2.31 & 1.21 & 1.01 & 0.84 \\
\hline $\mathrm{Na} 2 \mathrm{O}$ & 7.51 & 8.58 & 6.59 & 2.30 & 7.46 & 8.41 & 8.73 & 6.68 & 8.36 & 8.75 & 8.77 \\
\hline $\mathrm{K} 2 \mathrm{O}$ & 1.02 & 1.00 & 4.93 & 13.73 & 2.37 & 1.99 & 1.48 & 4.95 & 3.02 & 3.49 & 3.32 \\
\hline Total & 98.57 & 100.57 & 100.32 & 100.65 & 99.02 & 100.57 & 98.59 & 98.70 & 99.96 & 99.82 & 101.20 \\
\hline An & 27.27 & 18.56 & 13.27 & 0.99 & 17.37 & 16.90 & 14.49 & 11.40 & 6.09 & 4.82 & 4.04 \\
\hline$A b$ & 66.67 & 75.26 & 58.16 & 19.80 & 68.37 & 71.92 & 76.92 & 59.57 & 75.93 & 75.36 & 76.85 \\
\hline Or & 6.06 & 6.19 & 28.57 & 79.21 & 14.26 & 11.18 & 8.59 & 29.03 & 17.98 & 19.82 & 19.11 \\
\hline
\end{tabular}


Table 4. Selected analyses of glass, and average apatite in NWA 8694.

\begin{tabular}{|c|c|c|c|c|c|c|c|}
\hline & Al-rich GL 27 & Al-rich GL 3 & K-rich GL 109 & K-rich GL 78 & Al-poor GL 28 & Cat-poor GL 45 & $\begin{array}{c}\text { Fluorapatite } \\
\text { ave }\end{array}$ \\
\hline $\mathrm{SiO} 2$ & 64.74 & 67.23 & 70.24 & 71.35 & 72.51 & 79.44 & 0.48 \\
\hline $\mathrm{Al} 2 \mathrm{O} 3$ & 21.45 & 21.17 & 16.43 & 15.44 & 16.53 & 17.31 & 0.06 \\
\hline $\mathrm{FeO}$ & 1.19 & 1.39 & 0.88 & 1.03 & 0.72 & 0.93 & 0.70 \\
\hline $\mathrm{MgO}$ & 0.15 & 0.32 & 0.02 & b.d. & 0.02 & 0.01 & 0.15 \\
\hline $\mathrm{CaO}$ & 0.89 & 0.42 & 2.58 & 1.31 & 0.10 & b.d. & 53.48 \\
\hline $\mathrm{Na} 2 \mathrm{O}$ & 11.10 & 10.10 & 3.78 & 4.27 & 9.10 & 0.48 & 0.09 \\
\hline K2O & 0.08 & 0.03 & 5.20 & 4.81 & 0.06 & 1.34 & 0.09 \\
\hline P2O5 & b.d. & b.d. & b.d. & b.d. & b.d. & 0.02 & 42.00 \\
\hline $\mathrm{F}$ & b.d. & b.d. & b.d. & b.d. & 0.22 & n.d. & 2.34 \\
\hline $\mathrm{Cl}$ & 0.02 & n.d. & 1.38 & 1.18 & 0.06 & n.d. & 2.20 \\
\hline Total & 99.68 & 100.65 & 100.53 & 99.47 & 99.41 & 99.53 & 101.68 \\
\hline$-\mathrm{O}=\mathrm{F}$ & & & 0.01 & & 0.09 & & 0.99 \\
\hline $\begin{array}{c}-\mathrm{O}= \\
\mathrm{Cl}\end{array}$ & & & 0.31 & 0.27 & 0.01 & & 0.49 \\
\hline Total & & & 100.21 & 99.21 & 99.30 & & 100.20 \\
\hline $\mathrm{Ca}$ & 4.00 & 2.18 & 16.55 & 8.81 & 0.00 & 0.00 & \\
\hline $\mathrm{Na}$ & 95.00 & 97.71 & 43.74 & 52.41 & 100.00 & 36.36 & \\
\hline K & 1.00 & 0.11 & 39.70 & 38.78 & 0.00 & 63.64 & \\
\hline
\end{tabular}


Table 5. Mean composition of NWA 8694 sulfides

\begin{tabular}{ll} 
wt.\% & $\begin{array}{l}\text { enclosed pyrrhotite } \\
(\mathrm{n}=16)\end{array}$ \\
& $58.1(0.7)$ \\
$\mathrm{Fe}$ & $1.3(0.5)$ \\
$\mathrm{Ni}$ & $39.7(0.7)$ \\
$\mathrm{S}$ & 99.1 \\
Total & \\
& 0.87 \\
$\mathrm{Fe}+\mathrm{Ni} / \mathrm{S}($ at.\%) & \\
\hline
\end{tabular}

$\mathrm{n}=$ number of analyses 
Table 7. LA-ICP-MS average analyses (continued).

\begin{tabular}{|c|c|c|c|c|c|c|c|c|}
\hline & $\begin{array}{l}\text { bulk rock } \\
\text { NWA } 8694\end{array}$ & $\begin{array}{l}\text { olivine } \\
\text { NWA8693 }\end{array}$ & $\begin{array}{r}\text { pigeonite } \\
\text { NWA8694 }\end{array}$ & $\begin{array}{l}\text { mesostasis } \\
\text { NWA8694 }\end{array}$ & $\begin{array}{l}\text { olivine } \\
\text { Chassigny }\end{array}$ & $\begin{array}{l}\text { augite } \\
\text { Chassigny }\end{array}$ & $\begin{array}{l}\text { pigeonite38 } \\
\text { Chassigny }\end{array}$ & $\begin{array}{l}\text { mesostasis } \\
\text { Chassigny }\end{array}$ \\
\hline $\mathrm{n}$ & 8 & 5 & 5 & 11 & 7 & 2 & 1 & 6 \\
\hline $\mathrm{La}$ & 0.830 & 0.005 & 0.188 & 30.790 & 0.024 & 8.330 & 0.955 & 10.289 \\
\hline $\mathrm{Ce}$ & 3.442 & 0.006 & 0.636 & 67.687 & 0.051 & 22.297 & 3.626 & 23.355 \\
\hline $\operatorname{Pr}$ & 0.280 & 0.001 & 0.125 & 8.256 & 0.007 & 3.579 & 0.686 & 3.384 \\
\hline $\mathrm{Nd}$ & 1.117 & 0.006 & 0.739 & 32.125 & 0.021 & 17.412 & 3.540 & 14.026 \\
\hline Sm & 0.226 & 0.003 & 0.271 & 4.990 & 0.003 & 4.094 & 0.978 & 3.203 \\
\hline Eu & 0.067 & 0.001 & 0.060 & 2.146 & 0.001 & 0.862 & 0.202 & 1.740 \\
\hline Gd & 0.225 & 0.017 & 0.376 & 3.856 & 0.011 & 4.097 & 1.132 & 3.203 \\
\hline $\mathrm{Tb}$ & 0.034 & 0.005 & 0.071 & 0.447 & 0.004 & 0.602 & 0.182 & 0.498 \\
\hline Dy & 0.209 & 0.055 & 0.498 & 2.164 & 0.039 & 3.353 & 1.157 & 2.756 \\
\hline Ho & 0.043 & 0.018 & 0.108 & 0.335 & 0.013 & 0.596 & 0.217 & 0.486 \\
\hline $\mathrm{Er}$ & 0.125 & 0.071 & 0.317 & 0.653 & 0.050 & 1.414 & 0.583 & 1.111 \\
\hline $\mathrm{Tm}$ & 0.018 & 0.013 & 0.044 & 0.060 & 0.010 & 0.155 & 0.073 & 0.119 \\
\hline $\mathrm{Yb}$ & 0.117 & 0.092 & 0.273 & 0.276 & 0.071 & 0.801 & 0.398 & 0.578 \\
\hline Lu & 0.020 & 0.018 & 0.043 & 0.030 & 0.014 & 0.101 & 0.055 & 0.071 \\
\hline $\mathrm{Hf}$ & 0.255 & 0.008 & 0.071 & 3.633 & 0.006 & 0.608 & 0.365 & 1.242 \\
\hline $\mathrm{Ta}$ & 0.039 & 0.000 & 0.013 & 0.622 & 0.000 & 0.013 & 0.076 & 0.593 \\
\hline W & 0.094 & 0.004 & 0.041 & 0.461 & 0.013 & 0.019 & 0.070 & 0.652 \\
\hline $\mathrm{Re}$ & 0.0009 & & & & 0.0002 & -0.0001 & 0.0000 & 0.0007 \\
\hline Os & 0.0008 & & & & 0.0001 & 0.0002 & 0.0004 & 0.0009 \\
\hline Ir & 0.0008 & & & & 0.0001 & 0.0001 & 0.0010 & 0.0005 \\
\hline $\mathrm{Pt}$ & 0.2336 & & & & 0.0003 & 0.0006 & 0.0014 & 0.0393 \\
\hline $\mathrm{Au}$ & 0.0006 & & & & 0.0009 & 0.0007 & 0.0028 & 0.1086 \\
\hline TI & 0.007 & 0.001 & 0.003 & & 0.001 & 0.001 & 0.082 & 0.022 \\
\hline $\mathrm{Pb}$ & 0.545 & 0.156 & 0.236 & 5.516 & 0.177 & 0.418 & 12.803 & 3.542 \\
\hline $\mathrm{Bi}$ & 0.005 & 0.003 & 0.002 & 0.003 & 0.003 & 0.002 & 0.012 & 0.013 \\
\hline Th & 0.092 & 0.001 & 0.032 & 3.014 & 0.001 & 0.351 & 0.106 & 0.817 \\
\hline U & 0.082 & 0.030 & 0.102 & 0.563 & 0.002 & 0.083 & 0.019 & 0.211 \\
\hline
\end{tabular}


Table 7. LA-ICP-MS average analyses for NWA 8694 and Chassigny.

\begin{tabular}{|c|c|c|c|c|c|c|c|c|}
\hline & bulk rock & olivine & pigeonite & mesostasis & olivine & augite & pigeonite38 & mesostasis \\
\hline & NWA 8694 & NWA8693 & NWA8694 & NWA8694 & Chassigny & Chassigny & Chassigny & Chassigny \\
\hline $\mathrm{n}$ & 8 & 5 & 5 & 10 & 7 & 2 & 1 & 6 \\
\hline $\mathrm{SiO}_{2}$ & (EMP) 37.41 & 35,21 & 52,24 & 57,597 & 36,39 & 50,01 & 53,1 & 52,97 \\
\hline $\mathrm{Al}_{2} \mathrm{O}_{3}$ & 0,50 & 0,02 & 0,67 & 20,900 & 0,03 & 1,43 & 0,83 & 16,00 \\
\hline $\mathrm{TiO}_{2}$ & 0,06 & 0,03 & 0,16 & 0,067 & 0,02 & 0,31 & 0,182 & 0,43 \\
\hline $\mathrm{Cr}_{2} \mathrm{O}_{3}$ & 0,49 & 0,05 & 0,48 & 0,006 & 0,10 & 1,02 & 0,50 & 0,09 \\
\hline FeOT & 36,16 & 38,26 & 22,28 & 2,852 & 28,79 & 10,35 & 15,42 & 7,99 \\
\hline $\mathrm{MnO}$ & 0,81 & 0,84 & 0,77 & 0,059 & 0,57 & 0,36 & 0,481 & 0,19 \\
\hline $\mathrm{MgO}$ & 23,46 & 25,37 & 18,97 & 1,543 & 33,89 & 18,13 & 23,12 & 9,64 \\
\hline $\mathrm{CaO}$ & 0,82 & 0,22 & 4,77 & 5,687 & 0,19 & 17,73 & 6,35 & 7,09 \\
\hline $\mathrm{Na}_{2} \mathrm{O}$ & 0,17 & 0,02 & 0,13 & 7,190 & 0,02 & 0,39 & 0,17 & 4,55 \\
\hline $\mathrm{K}_{2} \mathrm{O}$ & 0,06 & 0,01 & 0,02 & 2,553 & 0,00 & 0,01 & 0,029 & 0,65 \\
\hline $\mathrm{P}_{2} \mathrm{O}_{5}$ & 0,05 & 0,03 & 0,01 & 1,531 & 0,03 & 0,57 & 0,00 & 0,42 \\
\hline $\mathrm{Li}$ & 3,43 & 4,49 & 3,82 & 43,576 & 4,29 & 4,58 & 2,58 & 37,89 \\
\hline $\mathrm{Be}$ & 0,04 & 0,01 & 0,09 & 1,048 & 0,01 & 0,09 & 0,17 & 2,14 \\
\hline B & 1,09 & 1,00 & 3,35 & 8,999 & 0,67 & 1,20 & 4,0 & 9,73 \\
\hline$S$ & 0,01 & 0,01 & 0,01 & 0,104 & 0,01 & 0,02 & 1,13 & 0,51 \\
\hline Sc & 7,62 & 6,77 & 25,82 & 4,581 & 6,21 & 52,99 & 29,3 & 10,31 \\
\hline V & 38,04 & 9,37 & 115,87 & 2,727 & 8,01 & 187,69 & 108 & 24,98 \\
\hline $\mathrm{Cr}$ & 0,34 & 356,33 & 3261,44 & 40,902 & 0,07 & 0,70 & 0,343 & 0,06 \\
\hline Co & 101,89 & 124,04 & 56,17 & 20,972 & 132,72 & 38,27 & 49 & 43,07 \\
\hline $\mathrm{Ni}$ & 258,72 & 345,13 & 114,08 & 51,030 & 500,06 & 126,18 & 140 & 338,98 \\
\hline $\mathrm{Cu}$ & 5,94 & 2,21 & 4,73 & 11,083 & 0,65 & 9,49 & 31 & 101,72 \\
\hline $\mathrm{Zn}$ & 95,87 & 109,16 & 84,45 & 10,979 & 70,01 & 22,91 & 44 & 26,44 \\
\hline $\mathrm{Ga}$ & 0,84 & 0,19 & 1,51 & 15,969 & 0,16 & 2,91 & 1,9 & 9,08 \\
\hline $\mathrm{Ge}$ & 0,84 & 1,28 & 2,23 & 0,554 & 1,19 & 1,83 & 1,73 & 1,91 \\
\hline As & 0,03 & 0,05 & 0,03 & 0,000 & 0,05 & 0,04 & 0,06 & 0,04 \\
\hline $\mathrm{Se}$ & 0,05 & 0,05 & 0,02 & 0,706 & 0,03 & 0,00 & 0,7 & 1,07 \\
\hline $\mathrm{Rb}$ & 1,53 & 0,17 & 0,67 & 40,765 & 0,13 & 0,29 & 1,6 & 14,20 \\
\hline $\mathrm{Sr}$ & 25,06 & 3,13 & 10,52 & 727,899 & 0,09 & 77,51 & 6,4 & 651,69 \\
\hline Y & 1,07 & 0,47 & 2,79 & 8,563 & 0,33 & 14,27 & 5,7 & 12,10 \\
\hline $\mathrm{Zr}$ & 9,64 & 0,33 & 2,30 & 153,441 & 0,18 & 12,23 & 12,1 & 44,90 \\
\hline $\mathrm{Nb}$ & 0,58 & 0,01 & 0,31 & 6,469 & 0,01 & 0,17 & 1,0 & 11,87 \\
\hline Mo & 0,11 & 0,09 & 0,10 & 0,480 & 0,07 & 0,06 & 0,065 & 0,44 \\
\hline $\mathrm{Ru}$ & 0,006 & & & & 0,006 & 0,005 & 0,007 & 0,072 \\
\hline $\mathrm{Rh}$ & 0,001 & & & & 0,000 & 0,001 & 0,002 & 0,019 \\
\hline $\mathrm{Pd}$ & 0,016 & & & & 0,005 & 0,023 & 0,020 & 0,100 \\
\hline $\mathrm{Ag}$ & 0,022 & 0,001 & 0,008 & 0,058 & 0,007 & 0,013 & 0,081 & 0,261 \\
\hline $\mathrm{Cd}$ & 0,049 & 0,129 & 0,097 & 0,136 & 0,087 & 0,085 & 0,115 & 0,178 \\
\hline In & 0,053 & 0,004 & 0,014 & 0,028 & 0,006 & 0,016 & 0,011 & 0,035 \\
\hline Sn & 0,468 & 0,020 & 0,040 & 0,212 & 0,028 & 0,037 & 0,088 & 0,282 \\
\hline $\mathrm{Sb}$ & 0,030 & 0,008 & 0,002 & 0,000 & 0,014 & 0,022 & 0,015 & 0,059 \\
\hline $\mathrm{Te}$ & 0,152 & 0,055 & 0,135 & 0,377 & 0,012 & 0,034 & 8,411 & 0,122 \\
\hline Cs & 0,155 & 0,042 & 0,112 & 2,514 & 0,038 & 0,099 & 0,223 & 2,393 \\
\hline $\mathrm{Ba}$ & 12,69 & 0,84 & 1,37 & 550,342 & 0,05 & 3,34 & 0,762 & 246,71 \\
\hline
\end{tabular}

Table 7. LA-ICP-MS average analyses (continued).

\begin{tabular}{|c|c|c|c|c|c|c|c|c|}
\hline & bulk rock & olivine & pigeonite & mesostasis & olivine & augite & pigeonite38 & mesostasis \\
\hline & NWA 8694 & NWA8693 & NWA8694 & NWA8694 & Chassigny & Chassigny & Chassigny & Chassigny \\
\hline$n$ & 8 & 5 & 5 & 10 & 7 & 2 & 1 & 6 \\
\hline La & 0,830 & 0,005 & 0,188 & 30,790 & 0,024 & 8,330 & 0,955 & 10,289 \\
\hline $\mathrm{Ce}$ & 3,442 & 0,006 & 0,636 & 67,687 & 0,051 & 22,297 & 3,626 & 23,355 \\
\hline $\mathrm{Pr}$ & 0,280 & 0,001 & 0,125 & 8,256 & 0,007 & 3,579 & 0,686 & 3,384 \\
\hline $\mathrm{Nd}$ & 1,117 & 0,006 & 0,739 & 32,125 & 0,021 & 17,412 & 3,540 & 14,026 \\
\hline $\mathrm{Sm}$ & 0,226 & 0,003 & 0,271 & 4,990 & 0,003 & 4,094 & 0,978 & 3,203 \\
\hline Eu & 0,067 & 0,001 & 0,060 & 2,146 & 0,001 & 0,862 & 0,202 & 1,740 \\
\hline $\mathrm{Gd}$ & 0,225 & 0,017 & 0,376 & 3,856 & 0,011 & 4,097 & 1,132 & 3,203 \\
\hline $\mathrm{Tb}$ & 0,034 & 0,005 & 0,071 & 0,447 & 0,004 & 0,602 & 0,182 & 0,498 \\
\hline Dy & 0,209 & 0,055 & 0,498 & 2,164 & 0,039 & 3,353 & 1,157 & 2,756 \\
\hline Ho & 0,043 & 0,018 & 0,108 & 0,335 & 0,013 & 0,596 & 0,217 & 0,486 \\
\hline $\mathrm{Er}$ & 0,125 & 0,071 & 0,317 & 0,653 & 0,050 & 1,414 & 0,583 & 1,111 \\
\hline Tm & 0,018 & 0,013 & 0,044 & 0,060 & 0,010 & 0,155 & 0,073 & 0,119 \\
\hline $\mathrm{Yb}$ & 0,117 & 0,092 & 0,273 & 0,276 & 0,071 & 0,801 & 0,398 & 0,578 \\
\hline Lu & 0,020 & 0,018 & 0,043 & 0,033 & 0,014 & 0,101 & 0,055 & 0,071 \\
\hline
\end{tabular}




\begin{tabular}{lrrrrrrrr}
$\mathrm{Hf}$ & 0,255 & 0,008 & 0,071 & 3,633 & 0,006 & 0,608 & 0,365 & 1,242 \\
$\mathrm{Ta}$ & 0,039 & 0,000 & 0,013 & 0,622 & 0,000 & 0,013 & 0,076 & 0,593 \\
$\mathrm{~W}$ & 0,094 & 0,004 & 0,041 & 0,461 & 0,013 & 0,019 & 0,070 & 0,652 \\
$\mathrm{Re}$ & 0,0009 & & & & 0,0002 & 0,0000 & 0,0000 & 0,0007 \\
$\mathrm{Os}$ & 0,0008 & & & & 0,0001 & 0,0002 & 0,0004 & 0,0009 \\
$\mathrm{Ir}$ & 0,0008 & & & & 0,0001 & 0,0001 & 0,0010 & 0,0005 \\
$\mathrm{Pt}$ & 0,2336 & & & & 0,0003 & 0,0006 & 0,0014 & 0,0393 \\
$\mathrm{Au}$ & 0,0006 & & & & 0,0009 & 0,0007 & 0,0028 & 0,1086 \\
$\mathrm{TI}$ & 0,007 & 0,001 & 0,003 & 0,042 & 0,001 & 0,001 & 0,082 & 0,022 \\
$\mathrm{~Pb}$ & 0,545 & 0,156 & 0,236 & 5,516 & 0,177 & 0,418 & 12,803 & 3,542 \\
$\mathrm{Bi}$ & 0,005 & 0,003 & 0,002 & 0,004 & 0,003 & 0,002 & 0,012 & 0,013 \\
$\mathrm{Th}$ & 0,092 & 0,001 & 0,032 & 3,014 & 0,001 & 0,351 & 0,106 & 0,817 \\
$\mathrm{U}$ & 0,082 & 0,030 & 0,102 & 0,563 & 0,002 & 0,083 & 0,019 & 0,211 \\
\hline
\end{tabular}


Table 7. LA-ICP-MS average analyses (continued).

\begin{tabular}{|c|c|c|c|c|c|c|c|c|}
\hline & bulk rock & olivine & pigeonite & mesostasis & olivine & augite & pigeonite38 & mesostasis \\
\hline & NWA 8694 & NWA8693 & NWA8694 & NWA8694 & Chassigny & Chassigny & Chassigny & Chassigny \\
\hline $\mathrm{n}$ & 8 & 5 & 5 & 10 & 7 & 2 & 1 & 6 \\
\hline La & 0,830 & 0,005 & 0,188 & 30,790 & 0,024 & 8,330 & 0,955 & 10,289 \\
\hline $\mathrm{Ce}$ & 3,442 & 0,006 & 0,636 & 67,687 & 0,051 & 22,297 & 3,626 & 23,355 \\
\hline $\mathrm{Pr}$ & 0,280 & 0,001 & 0,125 & 8,256 & 0,007 & 3,579 & 0,686 & 3,384 \\
\hline $\mathrm{Nd}$ & 1,117 & 0,006 & 0,739 & 32,125 & 0,021 & 17,412 & 3,540 & 14,026 \\
\hline Sm & 0,226 & 0,003 & 0,271 & 4,990 & 0,003 & 4,094 & 0,978 & 3,203 \\
\hline $\mathrm{Eu}$ & 0,067 & 0,001 & 0,060 & 2,146 & 0,001 & 0,862 & 0,202 & 1,740 \\
\hline Gd & 0,225 & 0,017 & 0,376 & 3,856 & 0,011 & 4,097 & 1,132 & 3,203 \\
\hline $\mathrm{Tb}$ & 0,034 & 0,005 & 0,071 & 0,447 & 0,004 & 0,602 & 0,182 & 0,498 \\
\hline Dy & 0,209 & 0,055 & 0,498 & 2,164 & 0,039 & 3,353 & 1,157 & 2,756 \\
\hline Ho & 0,043 & 0,018 & 0,108 & 0,335 & 0,013 & 0,596 & 0,217 & 0,486 \\
\hline $\mathrm{Er}$ & 0,125 & 0,071 & 0,317 & 0,653 & 0,050 & 1,414 & 0,583 & 1,111 \\
\hline $\mathrm{Tm}$ & 0,018 & 0,013 & 0,044 & 0,060 & 0,010 & 0,155 & 0,073 & 0,119 \\
\hline $\mathrm{Yb}$ & 0,117 & 0,092 & 0,273 & 0,276 & 0,071 & 0,801 & 0,398 & 0,578 \\
\hline Lu & 0,020 & 0,018 & 0,043 & 0,033 & 0,014 & 0,101 & 0,055 & 0,071 \\
\hline $\mathrm{Hf}$ & 0,255 & 0,008 & 0,071 & 3,633 & 0,006 & 0,608 & 0,365 & 1,242 \\
\hline Ta & 0,039 & 0,000 & 0,013 & 0,622 & 0,000 & 0,013 & 0,076 & 0,593 \\
\hline W & 0,094 & 0,004 & 0,041 & 0,461 & 0,013 & 0,019 & 0,070 & 0,652 \\
\hline $\mathrm{Re}$ & 0,0009 & & & & 0,0002 & 0,0000 & 0,0000 & 0,0007 \\
\hline Os & 0,0008 & & & & 0,0001 & 0,0002 & 0,0004 & 0,0009 \\
\hline Ir & 0,0008 & & & & 0,0001 & 0,0001 & 0,0010 & 0,0005 \\
\hline $\mathrm{Pt}$ & 0,2336 & & & & 0,0003 & 0,0006 & 0,0014 & 0,0393 \\
\hline $\mathrm{Au}$ & 0,0006 & & & & 0,0009 & 0,0007 & 0,0028 & 0,1086 \\
\hline TI & 0,007 & 0,001 & 0,003 & 0,042 & 0,001 & 0,001 & 0,082 & 0,022 \\
\hline $\mathrm{Pb}$ & 0,545 & 0,156 & 0,236 & 5,516 & 0,177 & 0,418 & 12,803 & 3,542 \\
\hline $\mathrm{Bi}$ & 0,005 & 0,003 & 0,002 & 0,004 & 0,003 & 0,002 & 0,012 & 0,013 \\
\hline Th & 0,092 & 0,001 & 0,032 & 3,014 & 0,001 & 0,351 & 0,106 & 0,817 \\
\hline U & 0,082 & 0,030 & 0,102 & 0,563 & 0,002 & 0,083 & 0,019 & 0,211 \\
\hline
\end{tabular}


Table 7. LA-ICP-MS average analyses for NWA 8694 and Chassigny.

\begin{tabular}{|c|c|c|c|c|c|c|c|c|}
\hline & bulk rock & olivine & pigeonite & mesostasis & olivine & augite & pigeonite 38 & mesostasis \\
\hline & NWA 8694 & NWA8693 & NWA8694 & NWA8694 & Chassigny & Chassigny & Chassigny & Chassigny \\
\hline $\mathrm{n}$ & 8 & 5 & 5 & 11 & 7 & 2 & 1 & 6 \\
\hline $\mathrm{SiO} 2$ & EMP 37.41 & 35.21 & 52.24 & 57.60 & 36.39 & 50.01 & 53.1 & 52.97 \\
\hline $\mathrm{Al} 2 \mathrm{O} 3$ & 0.50 & 0.02 & 0.67 & 20.90 & 0.03 & 1.43 & 0.83 & 16.00 \\
\hline TiO2 & 0.06 & 0.03 & 0.16 & 0.07 & 0.02 & 0.31 & 0.182 & 0.43 \\
\hline Cr2O3 & 0.49 & 0.05 & 0.48 & 0.01 & 0.10 & 1.02 & 0.50 & 0.09 \\
\hline FeOT & 36.16 & 38.26 & 22.28 & 2.85 & 28.79 & 10.35 & 15.42 & 7.99 \\
\hline $\mathrm{MnO}$ & 0.81 & 0.84 & 0.77 & 0.06 & 0.57 & 0.36 & 0.481 & 0.19 \\
\hline $\mathrm{MgO}$ & 23.46 & 25.37 & 18.97 & 1.54 & 33.89 & 18.13 & 23.12 & 9.64 \\
\hline $\mathrm{CaO}$ & 0.82 & 0.22 & 4.77 & 5.69 & 0.19 & 17.73 & 6.35 & 7.09 \\
\hline $\mathrm{Na} 2 \mathrm{O}$ & 0.17 & 0.02 & 0.13 & 7.19 & 0.02 & 0.39 & 0.17 & 4.55 \\
\hline K2O & 0.06 & 0.01 & 0.02 & 2.55 & 0.00 & 0.01 & 0.029 & 0.65 \\
\hline P2O5 & 0.05 & 0.03 & 0.01 & 1.53 & 0.03 & 0.57 & 0.00 & 0.42 \\
\hline $\mathrm{Li}$ & 3.43 & 4.49 & 3.82 & 43.58 & 4.29 & 4.58 & 2.58 & 37.89 \\
\hline $\mathrm{Be}$ & 0.04 & 0.01 & 0.09 & 1.05 & 0.01 & 0.09 & 0.17 & 2.14 \\
\hline B & 1.09 & 1.00 & 3.35 & 9.00 & 0.67 & 1.20 & 4.0 & 9.73 \\
\hline$S$ & 0.01 & 0.01 & 0.01 & 0.10 & 0.01 & 0.02 & 1.13 & 0.51 \\
\hline $\mathrm{Cl}$ & 269.00 & 385.31 & 388.60 & 363.28 & 372.72 & 642.33 & 367 & 497.14 \\
\hline Sc & 7.62 & 6.77 & 25.82 & 4.58 & 6.21 & 52.99 & 29.3 & 10.31 \\
\hline V & 38.04 & 9.37 & 115.87 & 2.73 & 8.01 & 187.69 & 108 & 24.98 \\
\hline $\mathrm{Cr}$ & 0.34 & 356.33 & 3261.44 & 39.22 & 0.07 & 0.70 & 0.343 & 0.06 \\
\hline Co & 101.89 & 124.04 & 56.17 & 20.97 & 132.72 & 38.27 & 49 & 43.07 \\
\hline $\mathrm{Ni}$ & 258.72 & 345.13 & 114.08 & 51.03 & 500.06 & 126.18 & 140 & 338.98 \\
\hline $\mathrm{Cu}$ & 5.94 & 2.21 & 4.73 & 11.08 & 0.65 & 9.49 & 31 & 101.72 \\
\hline $\mathrm{Zn}$ & 95.87 & 109.16 & 84.45 & 10.98 & 70.01 & 22.91 & 44 & 26.44 \\
\hline $\mathrm{Ga}$ & 0.84 & 0.19 & 1.51 & 15.97 & 0.16 & 2.91 & 1.9 & 9.08 \\
\hline $\mathrm{Ge}$ & 0.84 & 1.28 & 2.23 & 0.38 & 1.19 & 1.83 & 1.73 & 1.91 \\
\hline As & 0.03 & 0.05 & 0.03 & -0.21 & 0.05 & 0.04 & 0.06 & 0.04 \\
\hline $\mathrm{Se}$ & 0.05 & 0.05 & 0.02 & 0.02 & 0.03 & -0.07 & 0.7 & 1.07 \\
\hline $\mathrm{Rb}$ & 1.53 & 0.17 & 0.67 & 40.76 & 0.13 & 0.29 & 1.6 & 14.20 \\
\hline $\mathrm{Sr}$ & 25.06 & 3.13 & 10.52 & 727.90 & 0.09 & 77.51 & 6.4 & 651.69 \\
\hline$Y$ & 1.07 & 0.47 & 2.79 & 8.56 & 0.33 & 14.27 & 5.7 & 12.10 \\
\hline $\mathrm{Zr}$ & 9.64 & 0.33 & 2.30 & 153.44 & 0.18 & 12.23 & 12.1 & 44.90 \\
\hline $\mathrm{Nb}$ & 0.58 & 0.01 & 0.31 & 6.47 & 0.01 & 0.17 & 1.0 & 11.87 \\
\hline \multirow[t]{4}{*}{ Mo } & 0.11 & 0.09 & 0.10 & 0.48 & 0.07 & 0.06 & 0.065 & 0.44 \\
\hline & 0.01 & & & & 0.01 & 0.01 & 0.007 & 0.07 \\
\hline & 0.00 & & & & 0.00 & 0.00 & 0.002 & 0.02 \\
\hline & 0.02 & & & & 0.01 & 0.02 & 0.020 & 0.10 \\
\hline $\mathrm{Ag}$ & 0.02 & 0.00 & 0.01 & 0.05 & 0.01 & 0.01 & 0.081 & 0.26 \\
\hline $\mathrm{Cd}$ & 0.05 & 0.13 & 0.10 & 0.14 & 0.09 & 0.09 & 0.115 & 0.18 \\
\hline In & 0.05 & 0.00 & 0.01 & 0.03 & 0.01 & 0.02 & 0.011 & 0.04 \\
\hline Sn & 0.47 & 0.02 & 0.04 & 0.21 & 0.03 & 0.04 & 0.088 & 0.28 \\
\hline $\mathrm{Sb}$ & 0.03 & 0.01 & 0.00 & -0.08 & 0.01 & 0.02 & 0.015 & 0.06 \\
\hline $\mathrm{Te}$ & 0.15 & 0.06 & 0.14 & 0.30 & 0.01 & 0.03 & 8.4 & 0.12 \\
\hline Cs & 0.15 & 0.04 & 0.11 & 2.51 & 0.04 & 0.10 & 0.2 & 2.39 \\
\hline $\mathrm{Ba}$ & 12.69 & 0.84 & 1.37 & 550.34 & 0.05 & 3.34 & 1 & 246.71 \\
\hline
\end{tabular}


Table 8. Compositions of parent liquids and olivine used in PETROLOG calculations.

\begin{tabular}{|c|c|c|c|c|c|c|c|c|c|c|c|c|}
\hline Parent Liquid & $\mathrm{SiO} 2$ & $\mathrm{TiO} 2$ & $\mathrm{Al} 2 \mathrm{O} 3$ & $\mathrm{Cr} 2 \mathrm{O} 3$ & $\mathrm{FeO}$ & $\mathrm{MnO}$ & $\mathrm{MgO}$ & $\mathrm{CaO}$ & $\mathrm{Na} 2 \mathrm{O}$ & $\mathrm{K} 2 \mathrm{O}$ & P2O5 & Total \\
\hline NWA 2737 A\# (He) & 49.37 & 1.98 & 8.44 & 0.26 & 19.00 & 0.22 & 12.11 & 6.06 & 1.58 & 0.61 & 0.16 & 99.70 \\
\hline Parent 1-3KD & 50.92 & 0.09 & 8.00 & 0.39 & 26.00 & 0.58 & 6.50 & 3.45 & 2.70 & 1.44 & 0.41 & 100.48 \\
\hline Parent 2-1KD & 51.93 & 0.12 & 6.36 & 0.59 & 26.14 & 0.58 & 6.54 & 3.96 & 2.66 & 0.92 & 0.58 & 100.38 \\
\hline Parent 2-5KD & 48.07 & 0.09 & 4.78 & 0.46 & 32.40 & 0.72 & 8.1 & 3.1 & 1.59 & 0.84 & 0.25 & 100.40 \\
\hline Nakhla ol core (Treiman) & 33.60 & 0.05 & 0.08 & 0.03 & 48.60 & 0.96 & 17.50 & 0.29 & 0.05 & 0.00 & 0.00 & 100.70 \\
\hline NA01a (Stockstill) & 56.00 & 1.30 & 10.70 & 0.02 & 14.50 & 0.39 & 2.10 & 8.20 & 3.40 & 2.00 & 0.65 & 99.20 \\
\hline NA01a \&10ol & 53.76 & 1.18 & 9.64 & 0.02 & 17.91 & 0.45 & 3.64 & 7.41 & 3.07 & 1.80 & 0.59 & 99.35 \\
\hline NA01a \&20ol & 51.52 & 1.05 & 8.58 & 0.02 & 21.32 & 0.50 & 5.18 & 6.62 & 2.73 & 1.60 & 0.52 & 99.50 \\
\hline
\end{tabular}


Table S1. All LA-ICP-Ms analyses for NWA 8694 and Chassigny.

olivine olivine olivine olivine olivine pyroxene pyroxene pyroxene 26-NWA 27-NWA\&28-NWA 29-NWA 30-NWAr31-NWA8694 32-NWA8694 33-NWA8694

\begin{tabular}{|c|c|c|c|c|c|c|c|c|}
\hline $\mathrm{SiO} 2$ & 35,3 & 35,1 & 35,1 & 35,4 & 35,2 & 52,2 & 52,6 & 51,1 \\
\hline $\mathrm{Al} 2 \mathrm{O} 3$ & 0,02 & 0,02 & 0,05 & 0,02 & 0,02 & 0,74 & 0,66 & 0,64 \\
\hline TiO2 & 0,022 & 0,024 & 0,035 & 0,030 & 0,018 & 0,180 & 0,157 & 0,146 \\
\hline Cr2O3 & 0,02 & 0,02 & 0,19 & 0,02 & 0,02 & 0,85 & 0,41 & 0,37 \\
\hline FeOT & 38,02 & 38,44 & 38,38 & 38,24 & 38,24 & 21,97 & 22,00 & 22,69 \\
\hline MnO & 0,839 & 0,824 & 0,839 & 0,834 & 0,843 & 0,768 & 0,755 & 0,765 \\
\hline MgO & 25,50 & 25,35 & 25,36 & 25,22 & 25,42 & 18,82 & 18,83 & 19,14 \\
\hline $\mathrm{CaO}$ & 0,24 & 0,21 & 0,21 & 0,20 & 0,24 & 5,18 & 4,85 & 5,33 \\
\hline $\mathrm{Na2O}$ & 0,01 & 0,02 & 0,02 & 0,02 & 0,02 & 0,13 & 0,14 & 0,16 \\
\hline K2O & 0,003 & 0,004 & 0,007 & 0,006 & 0,006 & 0,012 & 0,011 & 0,020 \\
\hline P2O5 & 0,03 & 0,05 & 0,02 & 0,01 & 0,02 & 0,00 & 0,01 & 0,01 \\
\hline Li & 3,70 & 4,99 & 5,16 & 3,94 & 4,65 & 4,13 & 3,79 & 3,58 \\
\hline $\mathrm{Be}$ & 0,01 & 0,01 & 0,01 & 0,01 & 0,01 & 0,11 & 0,08 & 0,13 \\
\hline B & 1,03 & 0,91 & 1,35 & 0,84 & 0,87 & 3,35 & 3,13 & 3,27 \\
\hline $\mathbf{S}$ & 0,01 & 0,01 & 0,01 & 0,01 & 0,01 & 0,01 & 0,01 & 0,01 \\
\hline $\mathrm{Cl}$ & 414,38 & 399,34 & 374,20 & 380,21 & 358,39 & 435,03 & 364,58 & 407,57 \\
\hline Sc & 7,13 & 6,68 & 6,77 & 6,58 & 6,69 & 25,95 & 26,95 & 25,71 \\
\hline V & 6,46 & 6,07 & 21,04 & 6,60 & 6,66 & 142,05 & 116,12 & 108,68 \\
\hline $\mathrm{Cr}$ & 126,52 & 114,87 & 1274,46 & 133,55 & 132,26 & 5835,79 & 2793,37 & 2552,16 \\
\hline Co & 124,11 & 122,18 & 125,05 & 124,70 & 124,17 & 55,49 & 55,83 & 58,80 \\
\hline $\mathrm{Ni}$ & 345,91 & 337,60 & 352,26 & 343,64 & 346,26 & 109,55 & 113,85 & 126,11 \\
\hline $\mathrm{Cu}$ & 2,21 & 1,22 & 4,98 & 1,22 & 1,41 & 4,29 & 4,12 & 4,64 \\
\hline $\mathrm{Zn}$ & 108 & 107 & 106 & 114 & 111 & 94 & 81 & 78 \\
\hline Ga & 0,2 & 0,1 & 0,3 & 0,2 & 0,1 & 2,0 & 1,4 & 1,4 \\
\hline Ge & 1,39 & 1,21 & 1,29 & 1,17 & 1,33 & 2,24 & 2,25 & 2,08 \\
\hline As & 0,06 & 0,04 & 0,05 & 0,04 & 0,06 & 0,04 & 0,03 & 0,03 \\
\hline Se & 0,05 & 0,08 & 0,01 & 0,06 & 0,04 & 0,05 & 0,01 & 0,01 \\
\hline $\mathbf{R b}$ & 0,06 & 0,15 & 0,21 & 0,20 & 0,22 & 0,39 & 0,34 & 0,76 \\
\hline $\mathrm{Sr}$ & 2,88 & 2,93 & 4,41 & 2,94 & 2,49 & 9,65 & 9,31 & 12,16 \\
\hline Y & 0,56 & 0,45 & 0,42 & 0,49 & 0,43 & 2,96 & 2,58 & 3,46 \\
\hline $\mathrm{Zr}$ & 0,16 & 0,42 & 0,21 & 0,67 & 0,17 & 1,94 & 1,14 & 3,83 \\
\hline $\mathrm{Nb}$ & 0,00 & 0,01 & 0,01 & 0,01 & 0,00 & 0,24 & 0,12 & 0,46 \\
\hline Mo & 0,083 & 0,079 & 0,095 & 0,087 & 0,102 & 0,103 & 0,087 & 0,089 \\
\hline \multicolumn{9}{|l|}{$\mathrm{Ru}$} \\
\hline \multicolumn{9}{|l|}{$\mathrm{Rh}$} \\
\hline \multicolumn{9}{|l|}{$\mathrm{Pd}$} \\
\hline Ag & 0,001 & 0,001 & 0,002 & 0,001 & 0,001 & 0,002 & 0,002 & 0,031 \\
\hline Cd & 0,111 & 0,071 & 0,082 & 0,170 & 0,214 & 0,105 & 0,089 & 0,099 \\
\hline In & 0,004 & 0,003 & 0,004 & 0,005 & 0,005 & 0,009 & 0,008 & 0,040 \\
\hline Sn & 0,024 & 0,019 & 0,017 & 0,019 & 0,022 & 0,036 & 0,028 & 0,052 \\
\hline Sb & 0,005 & 0,002 & 0,003 & 0,010 & 0,017 & 0,002 & 0,002 & 0,002 \\
\hline Te & 0,092 & 0,042 & 0,036 & 0,067 & 0,039 & 0,146 & 0,178 & 0,128 \\
\hline Cs & 0,004 & 0,037 & 0,051 & 0,056 & 0,064 & 0,088 & 0,083 & 0,119 \\
\hline $\mathrm{Ba}$ & 0,753 & 0,679 & 1,055 & 0,796 & 0,902 & 1,037 & 0,969 & 1,392 \\
\hline La & 0,005 & 0,009 & 0,006 & 0,006 & 0,001 & 0,103 & 0,171 & 0,393 \\
\hline
\end{tabular}




\begin{tabular}{|c|c|c|c|c|c|c|c|c|}
\hline $\mathrm{Ce}$ & 0,006 & 0,012 & 0,005 & 0,006 & 0,002 & 0,452 & 0,547 & 1,362 \\
\hline $\mathrm{Pr}$ & 0,001 & 0,002 & 0,001 & 0,001 & 0,000 & 0,103 & 0,102 & 0,250 \\
\hline Nd & 0,007 & 0,010 & 0,008 & 0,004 & 0,003 & 0,670 & 0,601 & 1,425 \\
\hline Sm & 0,003 & 0,004 & 0,004 & 0,004 & 0,002 & 0,286 & 0,229 & 0,435 \\
\hline $\mathrm{Eu}$ & 0,001 & 0,001 & 0,001 & 0,001 & 0,001 & 0,063 & 0,057 & 0,084 \\
\hline Gd & 0,023 & 0,018 & 0,012 & 0,014 & 0,017 & 0,391 & 0,344 & 0,542 \\
\hline Tb & 0,006 & 0,004 & 0,004 & 0,005 & 0,005 & 0,079 & 0,063 & 0,097 \\
\hline Dy & 0,070 & 0,055 & 0,048 & 0,053 & 0,050 & 0,537 & 0,450 & 0,654 \\
\hline Ho & 0,023 & 0,017 & 0,013 & 0,018 & 0,017 & 0,115 & 0,101 & 0,133 \\
\hline $\mathrm{Er}$ & 0,082 & 0,065 & 0,065 & 0,077 & 0,064 & 0,343 & 0,292 & 0,376 \\
\hline Tm & 0,015 & 0,013 & 0,011 & 0,013 & 0,012 & 0,045 & 0,043 & 0,052 \\
\hline Yb & 0,101 & 0,098 & 0,087 & 0,097 & 0,079 & 0,291 & 0,263 & 0,295 \\
\hline Lu & 0,019 & 0,017 & 0,018 & 0,018 & 0,016 & 0,045 & 0,044 & 0,045 \\
\hline Hf & 0,004 & 0,011 & 0,007 & 0,014 & 0,005 & 0,065 & 0,048 & 0,113 \\
\hline $\mathrm{Ta}$ & 0,000 & 0,000 & 0,001 & 0,001 & 0,000 & 0,007 & 0,003 & 0,015 \\
\hline $\mathbf{W}$ & 0,005 & 0,003 & 0,008 & 0,003 & 0,003 & 0,019 & 0,029 & 0,043 \\
\hline \multicolumn{9}{|l|}{$\mathrm{Re}$} \\
\hline \multicolumn{9}{|l|}{ Os } \\
\hline \multicolumn{9}{|l|}{ Ir } \\
\hline \multicolumn{9}{|l|}{$\mathrm{Pt}$} \\
\hline \multicolumn{9}{|l|}{$\mathrm{Au}$} \\
\hline TI & 0,001 & 0,001 & 0,002 & 0,001 & 0,001 & 0,003 & 0,003 & 0,004 \\
\hline $\mathrm{Pb}$ & 0,303 & 0,093 & 0,219 & 0,110 & 0,055 & 0,223 & 0,192 & 0,365 \\
\hline $\mathbf{B i}$ & 0,003 & 0,002 & 0,002 & 0,004 & 0,005 & 0,003 & 0,001 & 0,002 \\
\hline Th & 0,000 & 0,001 & 0,001 & 0,001 & 0,000 & 0,017 & 0,018 & 0,046 \\
\hline U & 0,035 & 0,024 & 0,046 & 0,021 & 0,024 & 0,109 & 0,103 & 0,098 \\
\hline
\end{tabular}




\begin{tabular}{|c|c|c|c|c|c|c|}
\hline pyroxene & pyroxene & mesostasis & mesostasis & mesostasis & mesostasis & mesostasis \\
\hline 34-NWA8694 & 35-NWA8694 & 36-NWA8694 & 37-NWA8694 & 38-NWA8694 & 39-NWA8694 & 40-NWA8694 \\
\hline 52,7 & 52,6 & 42,5 & 57,9 & 58,1 & 59,6 & 60,5 \\
\hline 0,65 & 0,64 & 5,74 & 21,72 & 19,84 & 23,84 & 23,77 \\
\hline 0,150 & 0,155 & 0,072 & 0,073 & 0,055 & 0,078 & 0,076 \\
\hline 0,34 & 0,41 & 0,01 & 0,00 & 0,00 & 0,00 & 0,00 \\
\hline 22,87 & 21,85 & 27,34 & 4,40 & 2,65 & 0,55 & 0,24 \\
\hline 0,792 & 0,771 & 0,598 & 0,063 & 0,050 & 0,009 & 0,006 \\
\hline 19,18 & 18,88 & 18,14 & 1,77 & 1,25 & 0,35 & 0,28 \\
\hline 3,51 & 4,96 & 2,17 & 4,50 & 5,44 & 4,89 & 4,62 \\
\hline 0,12 & 0,13 & 2,21 & 7,46 & 7,18 & 9,04 & 8,42 \\
\hline 0,024 & 0,019 & 0,441 & 1,816 & 3,352 & 1,503 & 2,039 \\
\hline 0,01 & 0,01 & 0,82 & 0,34 & 2,04 & 0,12 & 0,11 \\
\hline 3,85 & 3,77 & 15,01 & 34,39 & 35,38 & 119,82 & 105,20 \\
\hline 0,08 & 0,07 & 0,40 & 1,10 & 1,06 & 1,17 & 1,14 \\
\hline 4,06 & 2,94 & 5,02 & 8,14 & 7,83 & 3,05 & 4,93 \\
\hline 0,01 & 0,01 & 0,03 & 0,92 & 0,02 & 0,00 & $-0,01$ \\
\hline 373,14 & 362,68 & 1209,72 & 224,42 & 1121,37 & $-1853,00$ & $-1581,53$ \\
\hline 23,36 & 27,11 & 5,98 & 4,48 & 4,65 & 8,75 & 5,56 \\
\hline 93,93 & 118,54 & 3,40 & 1,45 & 1,08 & 0,98 & 0,93 \\
\hline 2315,43 & 2810,46 & 62,79 & 18,08 & 10,54 & $-2,25$ & $-2,57$ \\
\hline 56,26 & 54,50 & 85,25 & 156,33 & 15,51 & 1,03 & $-0,33$ \\
\hline 113,24 & 107,67 & 260,71 & 100,28 & 41,93 & 67,45 & 56,32 \\
\hline 7,50 & 3,07 & 15,57 & 22,30 & 7,61 & 4,01 & 4,03 \\
\hline 88 & 81 & 88 & 15 & 12 & 4 & 3 \\
\hline 1,5 & 1,3 & 4,8 & 15,3 & 15,9 & 16,7 & 17,2 \\
\hline 2,22 & 2,35 & 1,31 & 0,86 & 0,63 & $-0,45$ & $-0,34$ \\
\hline 0,03 & 0,02 & 0,05 & $-0,08$ & $-0,16$ & $-0,10$ & $-0,78$ \\
\hline 0,00 & 0,04 & 0,01 & 2,39 & 0,18 & $-1,26$ & $-0,21$ \\
\hline 0,98 & 0,87 & 8,10 & 42,49 & 73,67 & 24,40 & 33,59 \\
\hline 12,37 & 9,10 & 195,53 & 601,21 & 681,29 & 760,75 & 765,33 \\
\hline 2,44 & 2,48 & 4,19 & 2,23 & 11,01 & 0,21 & 0,48 \\
\hline 2,94 & 1,64 & 2,13 & 13,58 & 2,86 & 0,30 & 14,11 \\
\hline 0,53 & 0,18 & 5,53 & 2,06 & 0,36 & 0,09 & 2,79 \\
\hline 0,118 & 0,085 & 0,204 & 0,423 & 0,367 & 1,256 & 0,973 \\
\hline 0,002 & 0,003 & 0,011 & 0,032 & 0,057 & $-0,011$ & 0,065 \\
\hline 0,115 & 0,077 & 0,044 & 0,101 & 0,040 & 0,250 & 0,246 \\
\hline 0,007 & 0,008 & 0,010 & 0,013 & 0,012 & 0,123 & 0,035 \\
\hline 0,047 & 0,037 & 0,179 & 0,198 & 0,565 & 0,186 & 0,218 \\
\hline 0,002 & 0,002 & 0,002 & $-0,037$ & $-0,042$ & $-0,269$ & $-0,170$ \\
\hline 0,146 & 0,078 & 0,613 & 0,529 & 0,158 & $-0,073$ & 0,014 \\
\hline 0,144 & 0,124 & 0,743 & 2,254 & 2,456 & 5,985 & 4,872 \\
\hline 2,514 & 0,962 & 106 & 350 & 538 & 442 & 559 \\
\hline 0,198 & 0,071 & 11,985 & 9,891 & 38,034 & 3,393 & 3,842 \\
\hline
\end{tabular}




\begin{tabular}{|c|c|c|c|c|c|c|}
\hline 0,529 & 0,289 & 23,597 & 17,398 & 81,142 & 4,939 & 5,650 \\
\hline 0,098 & 0,073 & 3,055 & 2,010 & 10,568 & 0,432 & 0,707 \\
\hline 0,530 & 0,471 & 12,934 & 8,125 & 41,784 & 1,499 & 2,545 \\
\hline 0,195 & 0,211 & 2,122 & 1,341 & 6,745 & 0,158 & 0,287 \\
\hline 0,043 & 0,052 & 0,629 & 1,634 & 2,177 & 1,885 & 2,018 \\
\hline 0,290 & 0,313 & 1,721 & 0,964 & 5,292 & 0,124 & 0,329 \\
\hline 0,057 & 0,059 & 0,202 & 0,125 & 0,598 & 0,016 & 0,034 \\
\hline 0,419 & 0,429 & 1,001 & 0,607 & 2,852 & 0,024 & 0,335 \\
\hline 0,097 & 0,097 & 0,167 & 0,072 & 0,437 & 0,009 & 0,028 \\
\hline 0,287 & 0,289 & 0,362 & 0,152 & 0,845 & 0,003 & 0,069 \\
\hline 0,037 & 0,040 & 0,035 & 0,025 & 0,082 & 0,001 & 0,005 \\
\hline 0,256 & 0,260 & 0,174 & 0,069 & 0,264 & 0,006 & 0,023 \\
\hline 0,042 & 0,041 & 0,027 & 0,011 & 0,034 & 0,023 & $-0,004$ \\
\hline 0,074 & 0,052 & 0,051 & 0,417 & 0,071 & 0,011 & 0,386 \\
\hline 0,029 & 0,013 & 0,280 & 0,191 & 0,043 & 0,005 & 0,144 \\
\hline 0,083 & 0,032 & 0,569 & 0,150 & 1,392 & 0,011 & 0,555 \\
\hline 0,004 & 0,003 & 0,012 & 0,032 & 0,030 & 0,008 & $-0,008$ \\
\hline 0,281 & 0,119 & 2,528 & 6,667 & 9,217 & 4,639 & 6,806 \\
\hline 0,001 & 0,002 & 0,001 & 0,002 & 0,005 & $-0,001$ & 0,009 \\
\hline 0,050 & 0,027 & 1,378 & 0,996 & 3,137 & 0,043 & 0,434 \\
\hline 0,111 & 0,091 & 0,264 & 0,183 & 0,655 & 0,019 & 0,082 \\
\hline
\end{tabular}




\begin{tabular}{|c|c|c|c|c|c|c|}
\hline mesostasis & mesostasis & mesostasis* & mesostasis & mesostasis & mesostasis & mesostasis (pr \\
\hline 41-NWA8694 & 42-NWA8694 & 43-NWA8694 & 44-NWA8694 & 45-NWA8694 & 46-NWA8694 & 47-NWA8694 \\
\hline 59,2 & 58,3 & 61,7 & 52,7 & 58,6 & 59,5 & 47,5 \\
\hline 22,96 & 19,92 & 18,97 & 15,17 & 23,78 & 24,04 & 15,91 \\
\hline 0,086 & 0,046 & 0,093 & 0,087 & 0,046 & 0,071 & 0,030 \\
\hline 0,00 & 0,00 & 0,00 & 0,05 & 0,00 & 0,00 & 0,00 \\
\hline 1,36 & 3,42 & 2,99 & 11,19 & 2,42 & 0,22 & 1,93 \\
\hline 0,027 & 0,067 & 0,061 & 0,278 & 0,035 & 0,004 & 0,044 \\
\hline 0,79 & 1,76 & 1,79 & 7,65 & 0,94 & 0,14 & 0,26 \\
\hline 5,14 & 4,86 & 1,47 & 5,79 & 5,21 & 5,58 & 15,07 \\
\hline 7,86 & 6,86 & 6,05 & 5,14 & 8,04 & 8,09 & 4,93 \\
\hline 1,954 & 3,180 & 6,519 & 0,869 & 0,891 & 1,820 & 4,145 \\
\hline 0,63 & 1,50 & 0,32 & 1,10 & 0,04 & 0,56 & 10,09 \\
\hline 31,45 & 28,44 & 21,43 & 24,89 & 24,55 & 34,29 & 19,50 \\
\hline 0,92 & 1,35 & 0,91 & 0,93 & 1,29 & 1,22 & 0,45 \\
\hline 11,16 & 12,63 & 16,27 & 5,22 & 6,56 & 6,87 & 16,32 \\
\hline 0,01 & 0,05 & 0,01 & 0,04 & 0,02 & 0,01 & 0,10 \\
\hline 318,88 & 692,30 & 269,00 & 549,96 & $-125,90$ & 470,59 & 3910,02 \\
\hline 3,40 & 3,25 & 3,31 & 6,58 & 2,68 & 3,37 & 4,34 \\
\hline 1,13 & 1,06 & 0,97 & 18,36 & 1,61 & 0,96 & 1,46 \\
\hline 4,31 & 17,93 & 9,78 & 358,48 & 13,64 & 0,40 & 3,11 \\
\hline 4,35 & 9,94 & 10,94 & 30,59 & 1,08 & 0,17 & 1,07 \\
\hline 32,28 & 50,30 & 42,42 & 99,98 & 23,85 & 23,45 & 23,06 \\
\hline 3,23 & 8,66 & 3,45 & 14,81 & 8,75 & 5,58 & 39,48 \\
\hline 9 & 12 & 11 & 39 & 3 & 5 & 8 \\
\hline 16,2 & 15,1 & 13,5 & 12,8 & 15,5 & 16,1 & 21,5 \\
\hline 0,64 & 0,50 & 0,58 & 0,75 & 0,61 & 0,53 & $-0,12$ \\
\hline$-0,18$ & $-0,10$ & $-0,16$ & $-0,03$ & $-0,10$ & $-0,20$ & $-0,41$ \\
\hline 0,47 & $-0,70$ & $-0,21$ & $-0,42$ & 0,30 & 0,19 & $-0,55$ \\
\hline 20,57 & 41,94 & 89,10 & 7,13 & 6,54 & 17,65 & 91,33 \\
\hline 842,57 & 675,95 & 379,71 & 732,51 & 903,56 & 870,11 & 793,89 \\
\hline 3,88 & 8,35 & 2,01 & 7,51 & 0,19 & 2,60 & 55,73 \\
\hline 41,83 & 2,99 & 106,00 & 8,25 & 0,33 & 39,98 & 1457,61 \\
\hline 6,45 & 0,39 & 37,99 & 0,84 & 0,09 & 4,61 & 15,49 \\
\hline 0,279 & 0,307 & 0,336 & 0,392 & 0,176 & 0,480 & 0,295 \\
\hline 0,030 & 0,033 & 0,021 & 0,006 & 0,002 & 0,094 & 0,243 \\
\hline 0,119 & 0,094 & 0,115 & 0,048 & 0,049 & 0,195 & 0,238 \\
\hline 0,024 & 0,018 & 0,012 & 0,010 & 0,022 & 0,024 & 0,019 \\
\hline 0,142 & 0,170 & 0,251 & 0,088 & 0,059 & 0,181 & 0,273 \\
\hline$-0,054$ & $-0,048$ & $-0,057$ & $-0,042$ & $-0,073$ & $-0,033$ & $-0,027$ \\
\hline 0,097 & 0,813 & 0,263 & 0,723 & 0,211 & $-0,061$ & 0,584 \\
\hline 2,002 & 1,837 & 2,024 & 1,319 & 1,179 & 1,733 & 1,994 \\
\hline 552 & 602 & 901 & 317 & 413 & 619,1 & 760,9 \\
\hline 15,174 & 30,476 & 9,660 & 23,157 & 4,123 & 12,185 & 188,750 \\
\hline
\end{tabular}




\begin{tabular}{|c|c|c|c|c|c|c|}
\hline 29,899 & 65,611 & 37,286 & 52,027 & 5,628 & 22,944 & 422,032 \\
\hline 4,230 & 8,347 & 2,227 & 6,503 & 0,489 & 2,929 & 52,367 \\
\hline 14,949 & 33,489 & 8,095 & 26,695 & 1,998 & 12,062 & 202,130 \\
\hline 2,204 & 5,447 & 1,263 & 3,926 & 0,158 & 1,697 & 31,669 \\
\hline 2,222 & 2,049 & 1,432 & 1,969 & 1,899 & 2,229 & 4,087 \\
\hline 1,833 & 4,302 & 0,947 & 3,446 & 0,165 & 1,475 & 23,544 \\
\hline 0,211 & 0,466 & 0,108 & 0,395 & 0,021 & 0,145 & 2,798 \\
\hline 1,000 & 2,211 & 0,499 & 1,910 & 0,053 & 0,694 & 13,619 \\
\hline 0,165 & 0,359 & 0,080 & 0,301 & 0,010 & 0,096 & 2,130 \\
\hline 0,256 & 0,630 & 0,204 & 0,607 & 0,009 & 0,186 & 4,228 \\
\hline 0,035 & 0,052 & 0,022 & 0,058 & 0,002 & 0,020 & 0,363 \\
\hline 0,177 & 0,233 & 0,096 & 0,315 & 0,013 & 0,082 & 1,757 \\
\hline 0,015 & 0,029 & 0,007 & 0,030 & 0,002 & 0,012 & 0,171 \\
\hline 1,089 & 0,090 & 2,344 & 0,294 & 0,034 & 1,464 & 33,761 \\
\hline 0,514 & 0,031 & 1,726 & 0,073 & 0,008 & 0,593 & 3,511 \\
\hline 0,202 & 0,565 & 0,130 & 0,152 & 0,282 & 0,870 & 0,763 \\
\hline 0,026 & 0,035 & 0,044 & 0,039 & 0,016 & 0,015 & 0,175 \\
\hline 4,304 & 4,634 & 5,915 & 3,170 & 3,953 & 4,283 & 7,090 \\
\hline 0,001 & 0,000 & 0,003 & $-0,001$ & 0,002 & 0,006 & 0,009 \\
\hline 1,617 & 2,510 & 5,199 & 1,321 & 0,035 & 1,153 & 16,709 \\
\hline 0,303 & 0,523 & 0,917 & 0,321 & 0,152 & 0,224 & 2,814 \\
\hline
\end{tabular}




\begin{tabular}{|c|c|c|c|c|c|c|}
\hline track & & olivine & olivine & olivine & olivine & olivine \\
\hline 48-NWA & 8694 & 26-Chassigny & 27-Chassigny & 28-Chassigny & 29-Chassigny & 30-Chassigny \\
\hline 33,2 & $\mathrm{SiO} 2$ & 36,5 & 36,2 & 36,5 & 36,3 & 36,5 \\
\hline 12,82 & $\mathrm{Al} 2 \mathrm{O} 3$ & 0,02 & 0,11 & 0,02 & 0,02 & 0,02 \\
\hline 1,281 & TiO2 & 0,021 & 0,035 & 0,017 & 0,017 & 0,018 \\
\hline 0,31 & $\mathrm{Cr} 2 \mathrm{O} 3$ & $\mathrm{e}+\mathrm{A} 1$ & 0,46 & 0,03 & 0,04 & 0,04 \\
\hline 23,18 & $\mathrm{FeO}(\mathrm{t})$ & 28,82 & 29,07 & 28,53 & 28,64 & 28,84 \\
\hline 0,527 & $\mathrm{MnO}$ & 0,571 & 0,574 & 0,566 & 0,564 & 0,568 \\
\hline 13,71 & $\mathrm{MgO}$ & 33,88 & 33,48 & 34,12 & 34,19 & 33,82 \\
\hline 11,21 & $\mathrm{CaO}$ & 0,15 & 0,17 & 0,19 & 0,22 & 0,21 \\
\hline 2,71 & $\mathrm{Na} 2 \mathrm{O}$ & 0,01 & 0,02 & 0,02 & 0,02 & 0,01 \\
\hline 0,557 & $\mathrm{~K} 2 \mathrm{O}$ & 0,003 & 0,004 & 0,003 & 0,004 & 0,004 \\
\hline 0,78 & P2O5 & 0,02 & 0,02 & 0,07 & 0,02 & 0,02 \\
\hline 2,46 & $\mathrm{Li}$ & 3,47 & 3,56 & 5,25 & 4,31 & 4,20 \\
\hline 0,33 & $\mathrm{Be}$ & 0,02 & 0,01 & 0,01 & 0,01 & 0,02 \\
\hline 5,39 & B & 0,52 & 0,62 & 0,85 & 0,55 & 0,58 \\
\hline 0,08 & $S$ & 0,03 & 0,01 & 0,01 & 0,01 & 0,01 \\
\hline 538,40 & $\mathrm{Cl}$ & 388,72 & 378,24 & 387,75 & 346,26 & 379,90 \\
\hline 28,60 & Sc & 6,00 & 6,06 & 6,69 & 6,22 & 6,41 \\
\hline 79,33 & V & 5,14 & 23,25 & 5,26 & 5,42 & 5,62 \\
\hline 2107,22 & $\mathrm{Cr}$ & 0,02 & 0,31 & 0,02 & 0,03 & 0,03 \\
\hline 70,23 & Co & 132,49 & 134,32 & 131,53 & 131,21 & 133,19 \\
\hline 613,09 & $\mathrm{Ni}$ & 509,00 & 505,32 & 494,34 & 489,57 & 498,85 \\
\hline 13,11 & $\mathrm{Cu}$ & 0,98 & 1,02 & 0,83 & 0,42 & 0,43 \\
\hline 55 & $\mathrm{Zn}$ & 69 & 71 & 68 & 69 & 71 \\
\hline 21,8 & $\mathrm{Ga}$ & 0,1 & 0,4 & 0,1 & 0,1 & 0,1 \\
\hline 2,55 & $\mathrm{Ge}$ & 1,03 & 1,14 & 1,34 & 1,33 & 1,25 \\
\hline 0,25 & As & 0,08 & 0,04 & 0,04 & 0,05 & 0,03 \\
\hline 0,28 & $\mathrm{Se}$ & 0,06 & 0,05 & $-0,02$ & 0,02 & 0,05 \\
\hline 22,22 & $\mathrm{Rb}$ & 0,11 & 0,13 & 0,10 & 0,13 & 0,13 \\
\hline 284,50 & $\mathrm{Sr}$ & 0,05 & 0,25 & 0,04 & 0,15 & 0,03 \\
\hline 85,15 & $Y$ & 0,33 & 0,40 & 0,31 & 0,33 & 0,35 \\
\hline 392,31 & $\mathrm{Zr}$ & 0,55 & 0,17 & 0,11 & 0,09 & 0,07 \\
\hline 22,19 & $\mathrm{Nb}$ & 0,00 & 0,01 & 0,00 & 0,00 & 0,02 \\
\hline \multirow[t]{4}{*}{0,190} & Mo & 0,054 & 0,057 & 0,068 & 0,086 & 0,069 \\
\hline & $\mathrm{Ru}$ & 0,005 & 0,003 & 0,005 & 0,010 & 0,007 \\
\hline & $\mathrm{Rh}$ & 0,001 & 0,000 & 0,001 & 0,000 & 0,000 \\
\hline & $\mathrm{Pd}$ & 0,007 & 0,004 & 0,005 & 0,005 & 0,003 \\
\hline 0,035 & $\mathrm{Ag}$ & 0,006 & 0,028 & 0,003 & 0,002 & 0,001 \\
\hline 0,292 & $\mathrm{Cd}$ & 0,089 & 0,077 & 0,067 & 0,075 & 0,090 \\
\hline 0,198 & In & 0,006 & 0,005 & 0,005 & 0,006 & 0,008 \\
\hline 1,671 & Sn & 0,035 & 0,031 & 0,025 & 0,018 & 0,026 \\
\hline 0,010 & $\mathrm{Sb}$ & 0,022 & 0,013 & 0,018 & 0,014 & 0,006 \\
\hline 0,603 & $\mathrm{Te}$ & 0,035 & 0,014 & 0,014 & 0,009 & 0,003 \\
\hline 0,464 & Cs & 0,042 & 0,032 & 0,030 & 0,032 & 0,041 \\
\hline 169,5 & $\mathrm{Ba}$ & 0,046 & 0,173 & 0,017 & 0,061 & 0,011 \\
\hline 26,786 & La & 0,007 & 0,027 & 0,028 & 0,030 & 0,009 \\
\hline
\end{tabular}




\begin{tabular}{|c|c|c|c|c|c|c|}
\hline 50,934 & $\mathrm{Ce}$ & 0,009 & 0,072 & 0,082 & 0,045 & 0,048 \\
\hline 7,950 & $\operatorname{Pr}$ & 0,001 & 0,008 & 0,006 & 0,014 & 0,002 \\
\hline 40,921 & $\mathrm{Nd}$ & 0,006 & 0,027 & 0,019 & 0,042 & 0,006 \\
\hline 12,098 & $\mathrm{Sm}$ & 0,002 & 0,004 & 0,002 & 0,006 & 0,006 \\
\hline 3,387 & $\mathrm{Eu}$ & 0,002 & 0,001 & 0,001 & 0,002 & 0,001 \\
\hline 17,992 & $\mathrm{Gd}$ & 0,008 & 0,015 & 0,010 & 0,012 & 0,012 \\
\hline 2,906 & $\mathrm{~Tb}$ & 0,003 & 0,004 & 0,004 & 0,004 & 0,004 \\
\hline 18,921 & Dy & 0,038 & 0,051 & 0,033 & 0,043 & 0,040 \\
\hline 3,969 & $\mathrm{Ho}$ & 0,012 & 0,014 & 0,013 & 0,013 & 0,013 \\
\hline 11,247 & Er & 0,052 & 0,058 & 0,050 & 0,048 & 0,047 \\
\hline 1,483 & $\mathrm{Tm}$ & 0,009 & 0,019 & 0,009 & 0,008 & 0,009 \\
\hline 8,815 & $\mathrm{Yb}$ & 0,068 & 0,076 & 0,075 & 0,071 & 0,066 \\
\hline 1,408 & Lu & 0,014 & 0,013 & 0,014 & 0,013 & 0,015 \\
\hline 13,947 & $\mathrm{Hf}$ & 0,019 & 0,007 & 0,004 & 0,003 & 0,002 \\
\hline 2,208 & $\mathrm{Ta}$ & 0,001 & 0,001 & 0,000 & 0,001 & 0,000 \\
\hline 2,716 & w & 0,009 & 0,035 & 0,007 & 0,008 & 0,012 \\
\hline & $\operatorname{Re}$ & 0,000 & 0,000 & 0,000 & 0,001 & 0,000 \\
\hline & Os & 0,000 & 0,000 & 0,000 & 0,001 & 0,000 \\
\hline & Ir & 0,000 & 0,000 & 0,000 & 0,000 & 0,000 \\
\hline & $\mathrm{Pt}$ & $-0,001$ & 0,001 & 0,001 & 0,000 & 0,000 \\
\hline & $\mathrm{Au}$ & 0,001 & 0,002 & 0,001 & 0,001 & 0,000 \\
\hline 0,122 & $\mathrm{TI}$ & 0,001 & 0,000 & 0,001 & 0,001 & 0,000 \\
\hline 13,110 & $\mathrm{~Pb}$ & 0,714 & 0,122 & 0,099 & 0,073 & 0,060 \\
\hline 0,038 & $\mathrm{Bi}$ & 0,003 & 0,002 & 0,003 & 0,002 & 0,002 \\
\hline 5,279 & Th & 0,001 & 0,002 & 0,000 & 0,000 & 0,000 \\
\hline 1,008 & U & 0,004 & 0,002 & 0,003 & 0,002 & 0,001 \\
\hline
\end{tabular}




\begin{tabular}{|c|c|c|c|c|c|c|}
\hline olivine & olivine & pyroxene & pyroxene & pyroxene & pyroxene & pyroxene \\
\hline 31-Chassigny & 32-Chassigny & 33-Chassigny & 34-Chassigny & 35-Chassigny & 36-Chassigny & 37-Chassigny \\
\hline 36,4 & 36,4 & 41,6 & 39,2 & 52,0 & 48,1 & 47,5 \\
\hline 0,02 & 0,02 & 0,33 & 0,80 & 1,28 & 1,58 & 9,31 \\
\hline 0,020 & 0,017 & 0,082 & 0,202 & 0,306 & 0,323 & 0,130 \\
\hline 0,04 & 0,04 & 0,59 & 3,48 & 1,11 & 0,93 & 0,30 \\
\hline 28,77 & 28,87 & 24,11 & 23,78 & 9,30 & 11,40 & 12,91 \\
\hline 0,572 & 0,573 & 0,567 & 0,511 & 0,358 & 0,371 & 0,434 \\
\hline 33,95 & 33,81 & 30,61 & 28,55 & 17,25 & 19,00 & 22,55 \\
\hline 0,18 & 0,19 & 2,14 & 4,43 & 18,41 & 17,05 & 4,36 \\
\hline 0,02 & 0,02 & 0,08 & 0,12 & 0,36 & 0,43 & 1,97 \\
\hline 0,004 & 0,004 & 0,008 & 0,010 & 0,005 & 0,020 & 0,623 \\
\hline 0,01 & 0,02 & 0,03 & 0,04 & 0,01 & 1,12 & 0,01 \\
\hline 4,19 & 5,06 & 4,48 & 5,14 & 4,89 & 4,27 & 315,95 \\
\hline 0,01 & 0,01 & 0,05 & 0,08 & 0,04 & 0,14 & 0,96 \\
\hline 0,74 & 0,81 & 1,43 & 1,59 & 1,13 & 1,27 & 9,61 \\
\hline 0,01 & 0,01 & 0,02 & 0,04 & 0,01 & 0,02 & 0,06 \\
\hline 372,89 & 355,32 & 427,58 & 353,27 & 317,76 & 966,91 & 453,90 \\
\hline 6,06 & 6,02 & 12,45 & 15,88 & 52,53 & 53,45 & 26,81 \\
\hline 5,62 & 5,76 & 48,74 & 171,19 & 196,04 & 179,34 & 56,47 \\
\hline 0,02 & 0,03 & 0,40 & 2,38 & 0,76 & 0,64 & 0,20 \\
\hline 132,56 & 133,73 & 110,30 & 108,55 & 32,29 & 44,25 & 43,78 \\
\hline 501,02 & 502,33 & 364,22 & 385,70 & 102,21 & 150,14 & 220,70 \\
\hline 0,54 & 0,34 & 12,84 & 5,12 & 2,60 & 16,39 & 8,35 \\
\hline 70 & 72 & 64 & 108 & 20 & 26 & 87 \\
\hline 0,1 & 0,1 & 0,8 & 3,4 & 2,5 & 3,3 & 4,9 \\
\hline 1,11 & 1,15 & 1,43 & 1,63 & 1,94 & 1,72 & 0,60 \\
\hline 0,05 & 0,04 & 0,15 & 0,23 & 0,04 & 0,04 & 0,34 \\
\hline 0,02 & 0,00 & 0,01 & 0,02 & $-0,12$ & $-0,02$ & 1,72 \\
\hline 0,15 & 0,16 & 0,22 & 0,36 & 0,22 & 0,36 & 29,97 \\
\hline 0,06 & 0,04 & 4,00 & 8,18 & 50,32 & 104,71 & 2,99 \\
\hline 0,31 & 0,32 & 1,74 & 2,28 & 10,98 & 17,57 & 4,52 \\
\hline 0,11 & 0,16 & 1,42 & 1,98 & 7,54 & 16,92 & 13,97 \\
\hline 0,00 & 0,00 & 0,07 & 0,38 & 0,05 & 0,28 & 0,43 \\
\hline 0,071 & 0,098 & 0,081 & 0,078 & 0,063 & 0,056 & 3,031 \\
\hline 0,008 & 0,005 & 0,005 & 0,008 & 0,005 & 0,006 & 0,310 \\
\hline 0,000 & 0,001 & 0,001 & 0,001 & 0,000 & 0,001 & 0,071 \\
\hline 0,005 & 0,007 & 0,015 & 0,011 & 0,021 & 0,026 & 0,249 \\
\hline 0,005 & 0,007 & 0,243 & 0,066 & 0,015 & 0,010 & 0,167 \\
\hline 0,090 & 0,118 & 0,272 & 0,081 & 0,088 & 0,083 & 0,899 \\
\hline 0,007 & 0,006 & 0,011 & 0,007 & 0,016 & 0,016 & 0,140 \\
\hline 0,027 & 0,033 & 1,543 & 0,111 & 0,030 & 0,045 & 0,139 \\
\hline 0,015 & 0,011 & 0,042 & 0,136 & 0,021 & 0,023 & $-0,100$ \\
\hline 0,004 & 0,006 & 0,010 & 0,091 & 0,027 & 0,040 & 0,483 \\
\hline 0,047 & 0,042 & 0,055 & 0,103 & 0,083 & 0,115 & 11,177 \\
\hline 0,034 & 0,025 & 0,324 & 0,421 & 0,111 & 7 & 1 \\
\hline 0,057 & 0,012 & 0,233 & 0,295 & 1,451 & 15,209 & 1,001 \\
\hline
\end{tabular}




\begin{tabular}{|c|c|c|c|c|c|c|}
\hline 0,039 & 0,058 & 0,910 & 1,219 & 6,393 & 38,202 & 3,142 \\
\hline 0,005 & 0,010 & 0,169 & 0,235 & 1,414 & 5,744 & 0,550 \\
\hline 0,021 & 0,027 & 0,961 & 1,289 & 8,408 & 26,417 & 2,304 \\
\hline 0,002 & 0,000 & 0,282 & 0,398 & 2,524 & 5,664 & 1,024 \\
\hline 0,000 & 0,001 & 0,072 & 0,101 & 0,596 & 1,129 & 0,165 \\
\hline 0,010 & 0,012 & 0,320 & 0,458 & 2,799 & 5,395 & 0,919 \\
\hline 0,003 & 0,003 & 0,052 & 0,075 & 0,436 & 0,769 & 0,105 \\
\hline 0,033 & 0,037 & 0,347 & 0,472 & 2,496 & 4,209 & 0,977 \\
\hline 0,012 & 0,012 & 0,072 & 0,092 & 0,456 & 0,737 & 0,203 \\
\hline 0,048 & 0,048 & 0,203 & 0,245 & 1,116 & 1,713 & 0,606 \\
\hline 0,009 & 0,009 & 0,026 & 0,033 & 0,127 & 0,183 & 0,085 \\
\hline 0,076 & 0,064 & 0,159 & 0,188 & 0,676 & 0,926 & 0,338 \\
\hline 0,014 & 0,013 & 0,025 & 0,029 & 0,088 & 0,113 & 0,034 \\
\hline 0,004 & 0,005 & 0,050 & 0,074 & 0,390 & 0,826 & 0,446 \\
\hline 0,000 & 0,000 & 0,004 & 0,015 & 0,004 & 0,022 & 0,036 \\
\hline 0,009 & 0,009 & 0,018 & 0,042 & 0,008 & 0,029 & 0,083 \\
\hline 0,000 & 0,000 & 0,000 & 0,001 & 0,000 & 0,000 & $-0,009$ \\
\hline 0,000 & 0,000 & 0,001 & 0,001 & 0,000 & 0,001 & 0,071 \\
\hline 0,000 & 0,000 & 0,000 & 0,001 & 0,000 & 0,000 & $-0,001$ \\
\hline 0,000 & 0,001 & $-0,001$ & 0,000 & 0,001 & 0,000 & $-0,025$ \\
\hline 0,001 & 0,000 & 0,002 & 0,007 & 0,001 & 0,001 & 0,217 \\
\hline 0,000 & 0,001 & 0,002 & 0,002 & 0,000 & 0,001 & 0,008 \\
\hline 0,091 & 0,079 & 4,399 & 24,466 & 0,244 & 0,592 & 5,590 \\
\hline 0,002 & 0,003 & 0,004 & 0,008 & 0,002 & 0,002 & 0,078 \\
\hline 0,000 & 0,000 & 0,012 & 0,030 & 0,008 & 0,695 & 0,082 \\
\hline 0,002 & 0,002 & 0,008 & 0,013 & 0,005 & 0,161 & 0,010 \\
\hline
\end{tabular}




\begin{tabular}{|c|c|c|c|c|c|c|}
\hline pyroxene & pyroxene & pyroxene? & melt? Plag & melt? & melt? & melt? \\
\hline 38-Chassigny & 39-Chassigny & 40-Chassigny & 41-Chassigny & 42-Chassigny & 43-Chassigny & 44-Chassigny \\
\hline 53,1 & 40,6 & 41,6 & 46,1 & 53,6 & 58,1 & 36,6 \\
\hline 0,83 & 2,22 & 0,21 & 29,25 & 16,15 & 11,50 & 0,36 \\
\hline 0,182 & 0,597 & 0,061 & 0,044 & 0,360 & 0,538 & 0,024 \\
\hline 0,50 & 18,86 & 0,13 & 0,01 & 0,05 & 0,09 & 0,03 \\
\hline 15,42 & 19,48 & 25,22 & 3,86 & 6,24 & 5,32 & 27,82 \\
\hline 0,481 & 0,537 & 0,561 & 0,084 & 0,186 & 0,186 & 0,563 \\
\hline 23,12 & 19,02 & 31,65 & 4,02 & 8,19 & 8,60 & 33,97 \\
\hline 6,35 & 4,44 & 0,59 & 14,21 & 9,61 & 9,00 & 0,28 \\
\hline 0,17 & 0,14 & 0,03 & 2,03 & 4,25 & 5,70 & 0,30 \\
\hline 0,029 & 0,015 & 0,009 & 0,333 & 0,319 & 0,240 & 0,078 \\
\hline 0,00 & 0,01 & 0,01 & 0,07 & 1,05 & 0,74 & 0,03 \\
\hline 2,58 & 2,71 & 4,06 & 71,91 & 57,09 & 43,44 & 37,99 \\
\hline 0,17 & 0,10 & 0,07 & 1,41 & 2,42 & 2,89 & 0,11 \\
\hline 3,97 & 1,58 & 0,90 & 2,49 & 10,24 & 14,72 & 1,61 \\
\hline 1,13 & 0,03 & 0,02 & 0,01 & 0,06 & 0,06 & 0,02 \\
\hline 366,53 & 337,46 & 358,90 & 118,25 & 441,53 & 642,40 & 484,75 \\
\hline 29,31 & 20,09 & 9,13 & 3,43 & 11,38 & 17,65 & 6,15 \\
\hline 107,80 & 620,51 & 22,53 & 1,91 & 15,52 & 27,89 & 5,10 \\
\hline 0,34 & 12,91 & 0,09 & 0,01 & 0,04 & 0,06 & 0,02 \\
\hline 48,94 & 76,79 & 110,17 & 16,23 & 21,82 & 17,37 & 132,16 \\
\hline 139,51 & 132,73 & 393,88 & 88,53 & 98,81 & 75,93 & 490,37 \\
\hline 31,47 & 8,05 & 0,64 & 3,63 & 6,59 & 7,52 & 20,01 \\
\hline 44 & 178 & 66 & 16 & 24 & 18 & 88 \\
\hline 1,9 & 9,7 & 0,5 & 16,4 & 10,1 & 7,7 & 0,4 \\
\hline 1,73 & 1,51 & 1,25 & 1,29 & 2,34 & 2,54 & 0,94 \\
\hline 0,06 & 0,05 & 0,04 & $-0,10$ & 0,11 & 0,00 & 0,09 \\
\hline 0,75 & $-0,02$ & 0,03 & $-0,24$ & $-0,30$ & $-0,52$ & $-0,06$ \\
\hline 1,64 & 0,58 & 0,45 & 10,73 & 7,36 & 6,58 & 3,85 \\
\hline 6,43 & 5,97 & 0,11 & 1592,84 & 751,50 & 182,48 & 9,91 \\
\hline 5,68 & 2,48 & 0,84 & 0,95 & 21,36 & 24,94 & 0,29 \\
\hline 12,05 & 1,97 & 1,04 & 1,45 & 56,45 & 103,77 & 0,75 \\
\hline 1,01 & 0,33 & 0,06 & 0,25 & 5,52 & 7,68 & 0,13 \\
\hline 0,065 & 0,085 & 0,089 & 0,608 & 0,434 & 0,315 & 0,353 \\
\hline 0,007 & 0,019 & 0,005 & 0,051 & 0,053 & 0,035 & 0,043 \\
\hline 0,002 & 0,001 & 0,001 & 0,014 & 0,005 & 0,011 & 0,008 \\
\hline 0,020 & 0,012 & 0,007 & 0,053 & 0,132 & 0,157 & 0,020 \\
\hline 0,081 & 0,029 & 0,009 & 0,094 & 0,414 & 0,106 & 1,852 \\
\hline 0,115 & 0,145 & 0,104 & 0,170 & 0,200 & 0,154 & 0,450 \\
\hline 0,011 & 0,010 & 0,009 & 0,023 & 0,058 & 0,051 & 0,060 \\
\hline 0,088 & 0,482 & 0,028 & 0,055 & 0,155 & 0,171 & 2,716 \\
\hline 0,015 & 0,020 & 0,017 & 0,000 & 0,097 & 0,139 & 0,023 \\
\hline 8,411 & 0,064 & 0,008 & 0,182 & 0,149 & 0,109 & 0,108 \\
\hline 0,223 & 0,161 & 0,169 & 3,120 & 2,464 & 1,853 & 1,414 \\
\hline 1 & 1 & 0 & 99 & 254 & 42 & 1 \\
\hline 1,0 & 0,4 & 0,1 & 6,7 & 22,6 & 14,5 & 0,3 \\
\hline
\end{tabular}




\begin{tabular}{|c|c|c|c|c|c|c|}
\hline 3,6 & 1,4 & 0,1 & 11,7 & 49,1 & 37,0 & 0,8 \\
\hline 0,7 & 0,2 & 0,0 & 1,2 & 7,2 & 6,0 & 0,1 \\
\hline 3,5 & 1,3 & 0,1 & 4,4 & 28,3 & 26,1 & 0,3 \\
\hline 1,0 & 0,4 & 0,0 & 0,6 & 6,1 & 6,1 & 0,0 \\
\hline 0,2 & 0,1 & 0,0 & 3,2 & 2,3 & 1,4 & 0,0 \\
\hline 1,1 & 0,4 & 0,1 & 0,6 & 5,9 & 6,3 & 0,1 \\
\hline 0,2 & 0,1 & 0,0 & 0,1 & 0,9 & 1,0 & 0,0 \\
\hline 1,2 & 0,5 & 0,1 & 0,3 & 5,0 & 5,6 & 0,0 \\
\hline 0,2 & 0,1 & 0,0 & 0,1 & 0,8 & 1,1 & 0,0 \\
\hline 0,6 & 0,3 & 0,1 & 0,1 & 1,9 & 2,4 & 0,0 \\
\hline 0,1 & 0,0 & 0,0 & 0,0 & 0,2 & 0,3 & 0,0 \\
\hline 0,4 & 0,2 & 0,1 & 0,1 & 0,9 & 1,2 & 0,1 \\
\hline 0,1 & 0,0 & 0,0 & 0,0 & 0,1 & 0,2 & 0,0 \\
\hline 0,365 & 0,075 & 0,034 & 0,033 & 1,578 & 2,948 & 0,030 \\
\hline 0,076 & 0,012 & 0,002 & 0,017 & 0,443 & 0,534 & 0,006 \\
\hline 0,070 & 0,058 & 0,027 & 0,051 & 0,723 & 0,962 & 0,028 \\
\hline 0,000 & 0,001 & 0,000 & $-0,003$ & 0,001 & $-0,002$ & 0,005 \\
\hline 0,000 & 0,000 & 0,000 & $-0,004$ & 0,005 & 0,001 & $-0,002$ \\
\hline 0,001 & 0,000 & 0,000 & 0,003 & 0,000 & 0,000 & 0,001 \\
\hline 0,001 & 0,002 & 0,000 & $-0,008$ & 0,002 & 0,006 & $-0,005$ \\
\hline 0,003 & 0,003 & 0,000 & 0,007 & 0,013 & 0,007 & 0,006 \\
\hline 0,082 & 0,004 & 0,001 & 0,012 & 0,017 & 0,036 & 0,003 \\
\hline 12,803 & 0,534 & 0,155 & 1,891 & 2,273 & 2,101 & 0,549 \\
\hline 0,012 & 0,002 & 0,002 & 0,006 & 0,020 & 0,003 & 0,015 \\
\hline 0,106 & 0,018 & 0,013 & 0,050 & 1,460 & 1,535 & 0,018 \\
\hline 0,019 & 0,009 & 0,003 & 0,035 & 0,367 & 0,355 & 0,007 \\
\hline
\end{tabular}




\begin{tabular}{|c|c|c|c|c|c|c|}
\hline melt? & melt? & chromite & opaque? & melt? & melt? & chromite \\
\hline 45-Chassigny & 46-Chassigny & 47-Chassigny & 48-Chassigny & 49-Chassigny & 50-Chassigny & 51-Chassigny \\
\hline 37,2 & 37,3 & 0,1 & 33,0 & 53,8 & 50,4 & 3,3 \\
\hline 0,17 & 0,03 & 8,64 & 12,65 & 12,11 & 7,26 & 7,74 \\
\hline 0,020 & 0,016 & 1,975 & 1,276 & 0,718 & 0,845 & 1,765 \\
\hline 0,03 & 0,04 & 73,48 & 0,43 & 0,18 & 0,20 & 69,48 \\
\hline 27,99 & 27,84 & 33,60 & 23,45 & 11,88 & 14,85 & 32,29 \\
\hline 0,565 & 0,558 & 0,504 & 0,525 & 0,209 & 0,353 & 0,509 \\
\hline 33,43 & 33,66 & 4,11 & 13,67 & 11,19 & 19,01 & 6,33 \\
\hline 0,25 & 0,25 & 0,14 & 11,10 & 2,43 & 3,25 & 0,06 \\
\hline 0,25 & 0,24 & 0,48 & 2,72 & 6,33 & 2,44 & 0,36 \\
\hline 0,064 & 0,074 & 0,154 & 0,556 & 0,741 & 1,261 & 0,118 \\
\hline 0,02 & 0,03 & 0,01 & 0,78 & 0,46 & 0,17 & 0,01 \\
\hline 35,21 & 40,64 & 71,87 & 2,11 & 35,15 & 5,36 & 46,48 \\
\hline 0,15 & 0,22 & 0,24 & 0,34 & 3,76 & 1,81 & 0,33 \\
\hline 1,46 & 0,90 & 2,13 & 5,42 & 20,15 & 8,51 & 1,33 \\
\hline 0,01 & 0,01 & 0,01 & 0,09 & 2,71 & 0,22 & 0,01 \\
\hline 377,19 & 389,20 & 328,95 & 630,73 & 785,56 & 638,51 & 228,37 \\
\hline 5,72 & 6,18 & 4,63 & 28,06 & 11,80 & 14,71 & 5,36 \\
\hline 4,76 & 5,54 & 2066,33 & 79,86 & 48,63 & 53,53 & 1970,61 \\
\hline 0,02 & 0,03 & 50,28 & 0,30 & 0,12 & 0,14 & 47,54 \\
\hline 127,46 & 127,00 & 183,47 & 67,46 & 112,06 & 64,22 & 176,60 \\
\hline 588,48 & 503,48 & 179,36 & 568,00 & 1358,25 & 298,79 & 200,28 \\
\hline 2,63 & 0,83 & 9,88 & 10,84 & 559,05 & 30,04 & 2,74 \\
\hline 82 & 81 & 1274 & 56 & 37 & 44 & 885 \\
\hline 0,3 & 0,2 & 38,7 & 20,5 & 5,0 & 4,5 & 30,1 \\
\hline 1,11 & 1,11 & 0,90 & 2,35 & 1,93 & 2,65 & 0,84 \\
\hline 0,06 & $-0,03$ & $-0,02$ & 0,24 & 0,05 & 0,09 & $-0,03$ \\
\hline 0,13 & $-0,19$ & $-0,27$ & 0,35 & 6,90 & 0,48 & $-0,28$ \\
\hline 3,09 & 3,72 & 8,13 & 22,30 & 21,39 & 28,41 & 6,52 \\
\hline 6,94 & 0,06 & 0,29 & 282,76 & 360,85 & 246,03 & 0,62 \\
\hline 0,27 & 0,22 & 0,03 & 84,53 & 13,53 & 11,74 & 0,08 \\
\hline 0,43 & 0,08 & 3,19 & 389,40 & 62,15 & 45,22 & 2,67 \\
\hline 0,05 & 0,01 & 0,98 & 22,12 & 33,86 & 23,85 & 0,75 \\
\hline 0,329 & 0,397 & 0,685 & 0,194 & 0,968 & 0,200 & 0,726 \\
\hline 0,059 & 0,041 & 0,263 & 0,034 & 0,228 & 0,033 & 0,247 \\
\hline 0,001 & $-0,001$ & 0,006 & 0,010 & 0,071 & 0,007 & 0,003 \\
\hline 0,021 & 0,023 & 0,042 & 0,173 & 0,171 & 0,072 & 0,022 \\
\hline 0,088 & 0,010 & 0,062 & 0,035 & 0,712 & 0,089 & 0,067 \\
\hline 0,080 & 0,179 & 0,227 & 0,314 & 0,193 & 0,116 & 0,161 \\
\hline 0,057 & 0,049 & 0,105 & 0,198 & 0,042 & 0,017 & 0,041 \\
\hline 0,068 & 0,052 & 0,102 & 1,828 & 0,681 & 0,478 & 0,071 \\
\hline 0,001 & $-0,015$ & $-0,002$ & 0,014 & 0,024 & 0,051 & 0,043 \\
\hline 0,346 & $-0,013$ & 0,231 & 0,628 & 0,198 & 0,048 & 0,275 \\
\hline 1,157 & 1,385 & 3,085 & 0,451 & 4,422 & 1,747 & 2,323 \\
\hline 1 & 0,0 & 0,1 & 169,6 & 403,4 & 203,3 & 2,1 \\
\hline 0,1 & 0,0 & 0,1 & 26,7 & 10,7 & 3,6 & 0,1 \\
\hline
\end{tabular}




\begin{tabular}{|c|c|c|c|c|c|c|}
\hline 0,4 & 0,2 & 0,2 & 51,1 & 26,5 & 11,2 & 0,5 \\
\hline 0,0 & 0,0 & 0,0 & 8,0 & 3,7 & 1,7 & 0,1 \\
\hline 0,2 & 0,1 & 0,1 & 40,7 & 16,1 & 8,3 & 0,0 \\
\hline 0,0 & 0,0 & 0,0 & 12,1 & 3,9 & 2,4 & 0,0 \\
\hline 0,0 & 0,0 & 0,0 & 3,4 & 1,1 & 0,8 & 0,0 \\
\hline 0,0 & 0,0 & 0,0 & 18,0 & 3,7 & 2,7 & 0,0 \\
\hline 0,0 & 0,0 & 0,0 & 2,9 & 0,6 & 0,4 & 0,0 \\
\hline 0,1 & 0,0 & 0,0 & 18,9 & 3,1 & 2,6 & 0,0 \\
\hline 0,0 & 0,0 & 0,0 & 4,0 & 0,5 & 0,5 & 0,0 \\
\hline 0,0 & 0,0 & 0,0 & 11,2 & 1,1 & 1,1 & 0,0 \\
\hline 0,0 & 0,0 & 0,0 & 1,5 & 0,1 & 0,1 & 0,0 \\
\hline 0,1 & 0,1 & 0,0 & 8,8 & 0,6 & 0,7 & 0,0 \\
\hline 0,0 & 0,0 & 0,0 & 1,4 & 0,1 & 0,1 & 0,0 \\
\hline 0,010 & 0,003 & 0,122 & 13,981 & 1,513 & 1,372 & 0,082 \\
\hline 0,004 & 0,000 & 0,037 & 2,177 & 1,543 & 1,012 & 0,021 \\
\hline 0,025 & 0,006 & 0,044 & 3,653 & 1,411 & 0,745 & 0,015 \\
\hline$-0,001$ & 0,000 & 0,005 & 0,002 & 0,009 & 0,001 & 0,011 \\
\hline$-0,004$ & 0,007 & $-0,008$ & 0,037 & 0,003 & 0,000 & 0,003 \\
\hline 0,000 & 0,000 & 0,000 & 0,039 & 0,000 & 0,000 & 0,003 \\
\hline$-0,001$ & 0,002 & $-0,012$ & 0,033 & 0,207 & 0,033 & 0,001 \\
\hline$-0,001$ & $-0,001$ & $-0,006$ & 0,012 & 0,017 & 0,003 & $-0,007$ \\
\hline 0,001 & 0,000 & 0,003 & 0,119 & 0,031 & 0,027 & 0,007 \\
\hline 0,258 & 0,035 & 1,305 & 13,454 & 5,046 & 5,024 & 3,525 \\
\hline 0,004 & 0,001 & 0,001 & 0,038 & 0,011 & 0,005 & 0,003 \\
\hline 0,007 & 0,000 & 0,004 & 5,289 & 1,269 & 0,577 & 0,004 \\
\hline 0,005 & 0,000 & 0,005 & 1,030 & 0,337 & 0,163 & 0,009 \\
\hline
\end{tabular}


melt? Plag

52-Chassigny
56-NWA8694 57-NWA8694 58-NWA8694 59-NWA8694 60-NWA8694

55,8 $\mathrm{SiO} 2$
19,72 $\mathrm{Al} 2 \mathrm{O} 3$
0,047 $\mathrm{TiO} 2$
0,03 $\mathrm{Cr} 2 \mathrm{O} 3$
5,81 $\mathrm{FeOT}$
0,114 $\mathrm{MnO}$
6,88 $\mathrm{MgO}$
4,04 $\mathrm{CaO}$
6,57 $\mathrm{Na2O}$
1,032 $\mathrm{K} 2 \mathrm{O}$
0,02 $\mathrm{P} 2 \mathrm{O} 5$

$14,42 \mathrm{Li}$

$0,55 \mathrm{Be}$

2,24 B

$0,02 \mathrm{~S}$

$356,62 \mathrm{Cl}$

$2,86 \mathrm{Sc}$

$2,42 \mathrm{~V}$

$0,02 \mathrm{Cr}$

26,72 Co

$113,59 \mathrm{Ni}$

3,50 Cu

$21 \mathrm{Zn}$

$10,7 \mathrm{Ga}$

$0,73 \mathrm{Ge}$

0,07 As

$0,08 \mathrm{Se}$

10,70

$776,42 \mathrm{Rb}$

$0,09 \mathrm{Sr}$

$0,33 \mathrm{Y}$

$0,09 \mathrm{Zr}$

$0,144 \mathrm{Nb}$

$0,035 \mathrm{Mo}$

0,005

$0,016 \mathrm{Ag}$

$0,153 \mathrm{Cd}$

0,238 In

$0,020 \mathrm{Sn}$

$0,152 \mathrm{Sb}$

$0,042 \mathrm{Te}$

0,045

0,753 Cs

$478,4 \mathrm{Ba}$

3,6 La

32,1
0,63
0,058
0,39
39,3
0,88
25,
0,86
0,2
0,063
0,071

0,63

0,058

0,39

39,3

0,881

25,6

0,86

0,22

0,063

0,071

3,56

0,05

1,24

0,02

291,09

7,60

31,89

0,27

112,99

285,53

4,39

102

0,9

0,88

0,01

0,05

1,15

35,53

1,18

10,07

0,55

0,097

0,005

0,001

0,017

0,023

0,044

0,007

0,234

0,019

0,136

0,070

18,2

1,17

\begin{abstract}
31,2
\end{abstract}
0,41

0,048

0,26

40,4

0,895

26,2

0,47

0,15

0,069

0,059

3,83

0,04

1,17

0,01

281,00

6,95

21,13

0,18

115,20

296,49

5,50

101

0,6

0,88

0,01

0,04

2,06

21,70

0,88

7,84

1,41

0,102

0,007

0,001

0,014

0,017

0,031

0,007

0,385

0,015

0,123

0,148

12,2

0,87
31,2
0,42
0,080
0,78
40,1
0,893
25,9
0,69
0,13
0,052
0,039

3,79

0,03

1,14

0,01

255,20

7,97

52,56

0,53

114,14

290,61

6,02

106

1,0

0,90

0,03

0,04

1,45

20,22

0,95

10,73

0,64

0,124

0,008

0,001

0,018

0,024

0,161

0,390

0,530

0,069

0,130

0,218

9,3

0,48
32,2

0,81

0,076

0,52

39,0

0,873

25,3

1,04

0,26

0,086

0,080

3,86

0,05

1,53

0,02

271,32

8,47

42,45

0,35

109,96

287,48

11,59

105

1,1

0,92

0,04

0,06

2,22

39,70

1,42

10,45

0,61

0,119

0,014

0,003

0,018

0,023

0,034

0,012

0,697

0,021

0,351

0,183

20,0

1,51
31,4

0,58

0,081

0,72

39,8

0,890

25,6

0,78

0,19

0,057

0,056

3,72

0,04

1,10

0,01

245,53

7,96

49,72

0,49

111,57

281,65

6,94

107

1,0

0,91

0,06

0,06

1,26

29,76

1,06

9,85

0,45

0,119

0,006

0,001

0,016

0,025

0,032

0,012

0,672

0,027

0,163

0,189

14,7

0,81 


$\begin{array}{crrrrr}\text { 4,7 Ce } & 4,16 & 2,96 & 2,97 & 5,03 & 3,49 \\ 0,4 \mathrm{Pr} & 0,38 & 0,26 & 0,20 & 0,48 & 0,27 \\ 1,0 \mathrm{Nd} & 1,49 & 1,01 & 0,71 & 1,93 & 1,09 \\ 0,1 \mathrm{Sm} & 0,28 & 0,18 & 0,16 & 0,37 & 0,22 \\ 1,6 \mathrm{Eu} & 0,09 & 0,05 & 0,05 & 0,11 & 0,07 \\ 0,0 \mathrm{Gd} & 0,26 & 0,17 & 0,16 & 0,35 & 0,22 \\ 0,0 \mathrm{~Tb} & 0,04 & 0,02 & 0,03 & 0,05 & 0,03 \\ 0,0 \mathrm{Dy} & 0,23 & 0,16 & 0,17 & 0,30 & 0,20 \\ 0,0 \mathrm{Ho} & 0,05 & 0,03 & 0,04 & 0,06 & 0,04 \\ 0,0 \mathrm{Er} & 0,13 & 0,11 & 0,12 & 0,16 & 0,13 \\ 0,0 \mathrm{Tm} & 0,02 & 0,02 & 0,02 & 0,02 & 0,02 \\ 0,0 \mathrm{Yb} & 0,12 & 0,11 & 0,12 & 0,13 & 0,12 \\ 0,0 \mathrm{Lu} & 0,02 & 0,02 & 0,02 & 0,02 & 0,02 \\ 0,009 \mathrm{Hf} & 0,261 & 0,203 & 0,262 & 0,284 & 0,260 \\ 0,009 \mathrm{Ta} & 0,045 & 0,068 & 0,043 & 0,051 & 0,032 \\ 0,022 \mathrm{~W} & 0,091 & 0,111 & 0,092 & 0,111 & 0,106 \\ 0,000 \mathrm{Tl} & 0,000 & 0,000 & 0,004 & 0,000 & 0,002 \\ 0,002 \mathrm{~Pb} & 0,001 & 0,000 & 0,001 & 0,003 & 0,001 \\ 0,000 \mathrm{Bi} & 0,001 & 0,001 & 0,001 & 0,003 & 0,001 \\ -0,004 \mathrm{Th} & 1,895 & 0,066 & 0,005 & 0,002 & 0,002 \\ 0,605 \mathrm{U} & 0,001 & 0,001 & 0,001 & 0,001 & 0,001 \\ 0,009 \mathrm{Th} / \mathrm{U} & 0,006 & 0,006 & 0,008 & 0,011 & 0,007 \\ 4,916 \mathrm{OM} & 0,688 & 0,458 & 0,558 & 0,895 & 0,549 \\ 0,031 \mathrm{Cl}-\text { normalized F } & 0,005 & 0,003 & 0,012 & 0,004 & 0,008 \\ 0,009 & 0,123 & 0,123 & 0,078 & 0,135 & 0,076 \\ 0,009 \mathrm{La} & 0,071 & 0,069 & 0,068 & 0,088 & 0,226 \\ & & & & & \end{array}$


61-NWA8694 62-NWA8694 63-NWA8694

$\begin{array}{rrr}32,0 & 32,4 & 32,4 \\ 0,44 & 0,59 & 0,50 \\ 0,077 & 0,077 & 0,063 \\ 0,69 & 0,60 & 0,32 \\ 39,3 & 38,9 & 39,0 \\ 0,891 & 0,885 & 0,881 \\ 25,6 & 25,3 & 25,4 \\ 0,99 & 1,13 & 1,19 \\ 0,14 & 0,20 & 0,18 \\ 0,047 & 0,066 & 0,068 \\ 0,048 & 0,061 & 0,052 \\ & & \\ 3,63 & 3,66 & 3,89 \\ 0,03 & 0,04 & 0,05 \\ 1,02 & 1,13 & 1,15 \\ 0,01 & 0,01 & 0,01 \\ 258,44 & 415,73 & 329,62 \\ 9,00 & 9,25 & 9,29 \\ 52,11 & 48,23 & 33,94 \\ 0,47 & 0,41 & 0,22 \\ 109,19 & 108,13 & 108,15 \\ 273,36 & 271,29 & 271,88 \\ 5,15 & 6,54 & 5,70 \\ 106 & 107 & 103 \\ 0,9 & 1,0 & 0,8 \\ 0,95 & 0,95 & 0,95 \\ 0,01 & 0,01 & 0,09 \\ 0,02 & 0,09 & 0,05 \\ 1,47 & 1,73 & 2,00 \\ 20,43 & 27,64 & 23,78 \\ 1,16 & 1,31 & 1,35 \\ 7,56 & 12,71 & 14,92 \\ 0,40 & 0,51 & 0,54 \\ 0,139 & 0,116 & 0,126 \\ 0,004 & 0,005 & 0,005 \\ 0,000 & 0,001 & 0,001 \\ 0,013 & 0,019 & 0,022 \\ 0,019 & 0,035 & 0,022 \\ 0,033 & 0,056 & 0,034 \\ 0,007 & 0,018 & 0,007 \\ 0,391 & 0,693 & 0,484 \\ 0,042 & 0,036 & 0,035 \\ 0,107 & 0,212 & 0,109 \\ 0,183 & 0,164 & 0,196 \\ 0,60 & 14,8 & 12,3 \\ & 0,97 & 0,83\end{array}$




$\begin{array}{lll}2,60 & 4,36 & 4,48 \\ 0,23 & 0,32 & 0,30 \\ 0,96 & 1,32 & 1,26 \\ 0,21 & 0,27 & 0,28 \\ 0,06 & 0,08 & 0,07 \\ 0,23 & 0,28 & 0,29 \\ 0,03 & 0,04 & 0,04 \\ 0,23 & 0,26 & 0,28 \\ 0,05 & 0,06 & 0,06 \\ 0,14 & 0,16 & 0,16 \\ 0,02 & 0,02 & 0,02 \\ 0,13 & 0,14 & 0,14 \\ 0,02 & 0,02 & 0,02 \\ 0,213 & 0,336 & 0,407 \\ 0,026 & 0,036 & 0,040 \\ 0,076 & 0,108 & 0,124 \\ 0,000 & 0,001 & 0,000 \\ 0,000 & 0,000 & 0,000 \\ 0,000 & 0,001 & 0,000 \\ 0,001 & 0,065 & 0,002 \\ 0,001 & 0,001 & 0,001 \\ 0,007 & 0,006 & 0,007 \\ 0,485 & 0,593 & 0,534 \\ 0,004 & 0,006 & 0,004 \\ 0,066 & 0,107 & 0,097 \\ 0,057 & 0,071 & 0,067 \\ & & \\ & & \\ & & \end{array}$




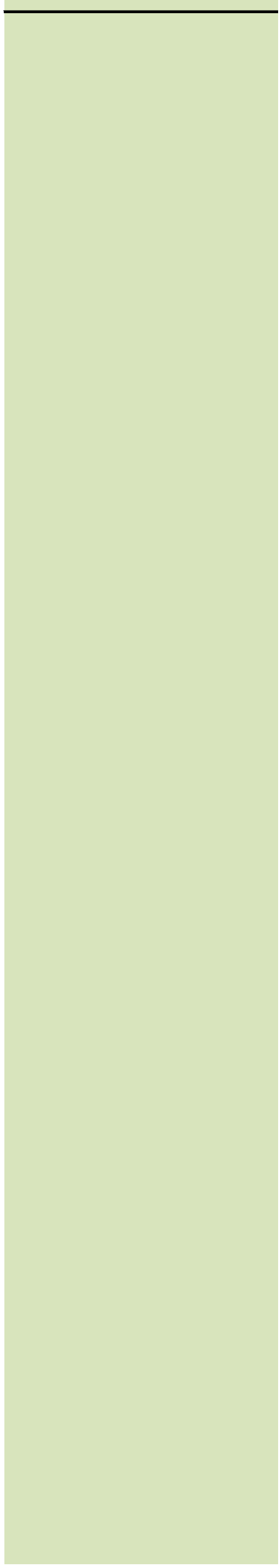




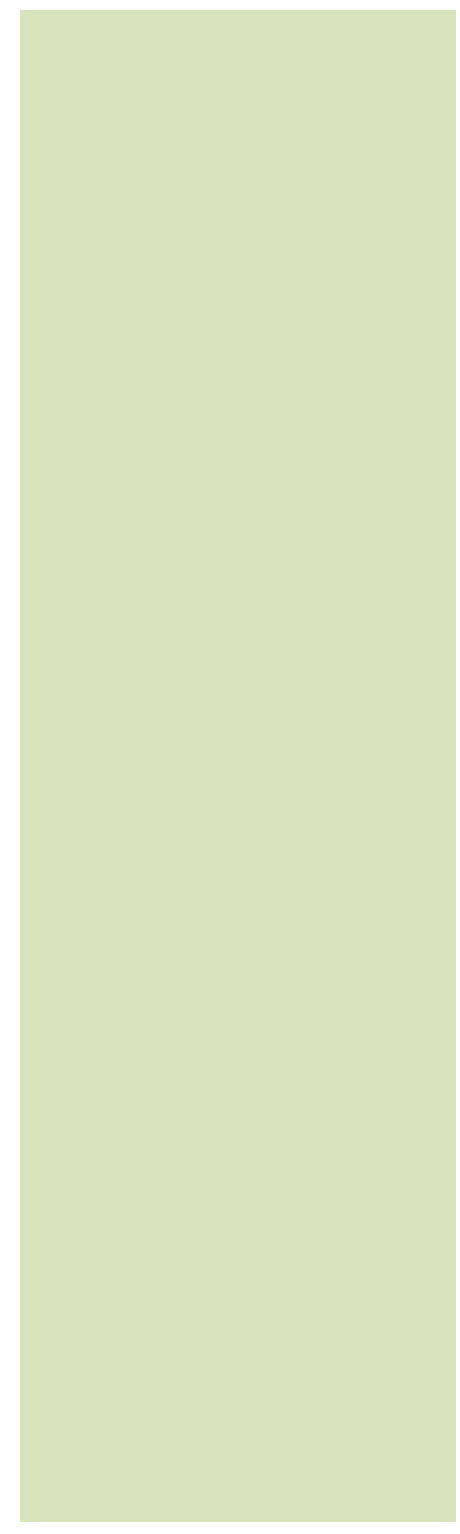




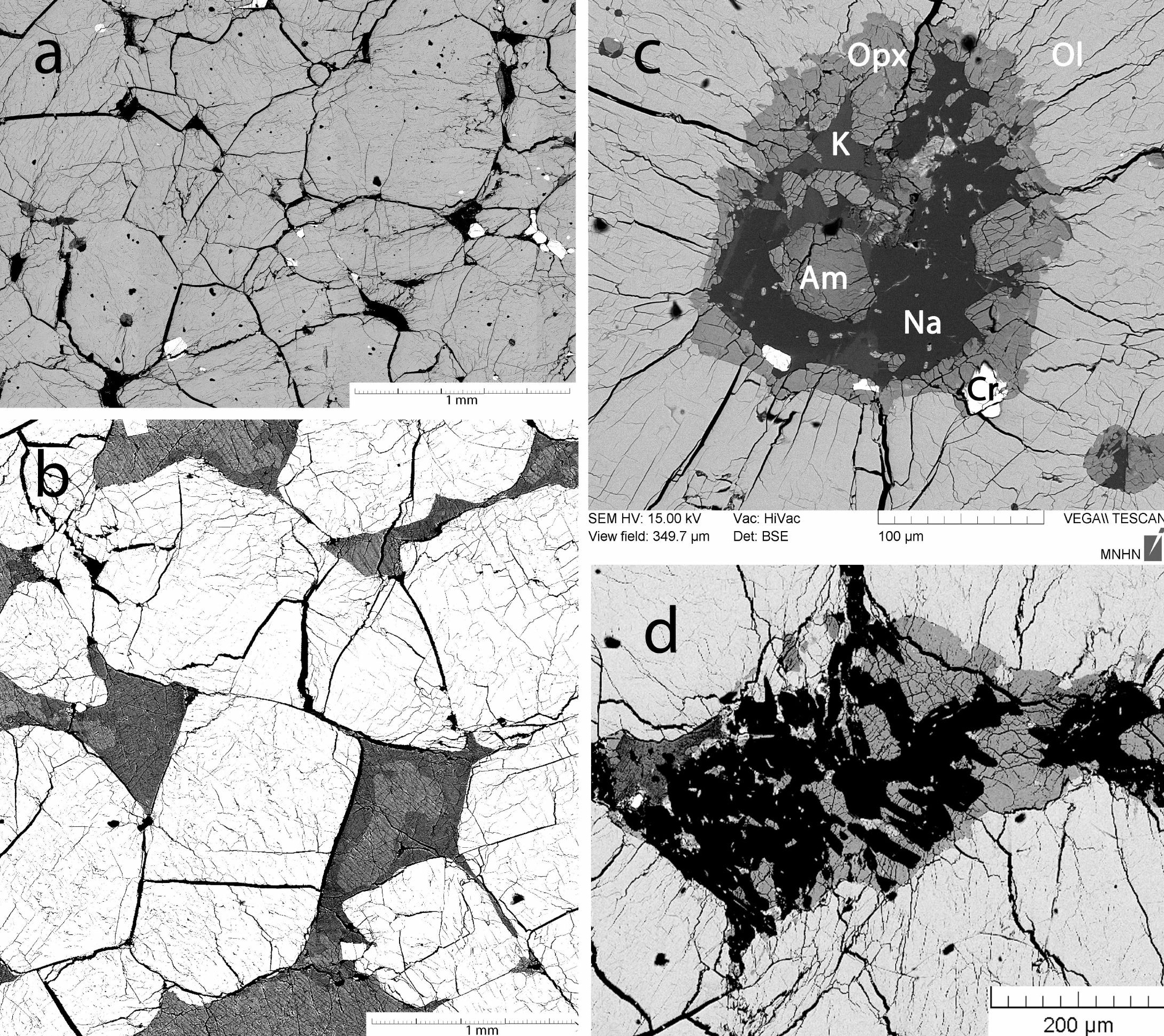




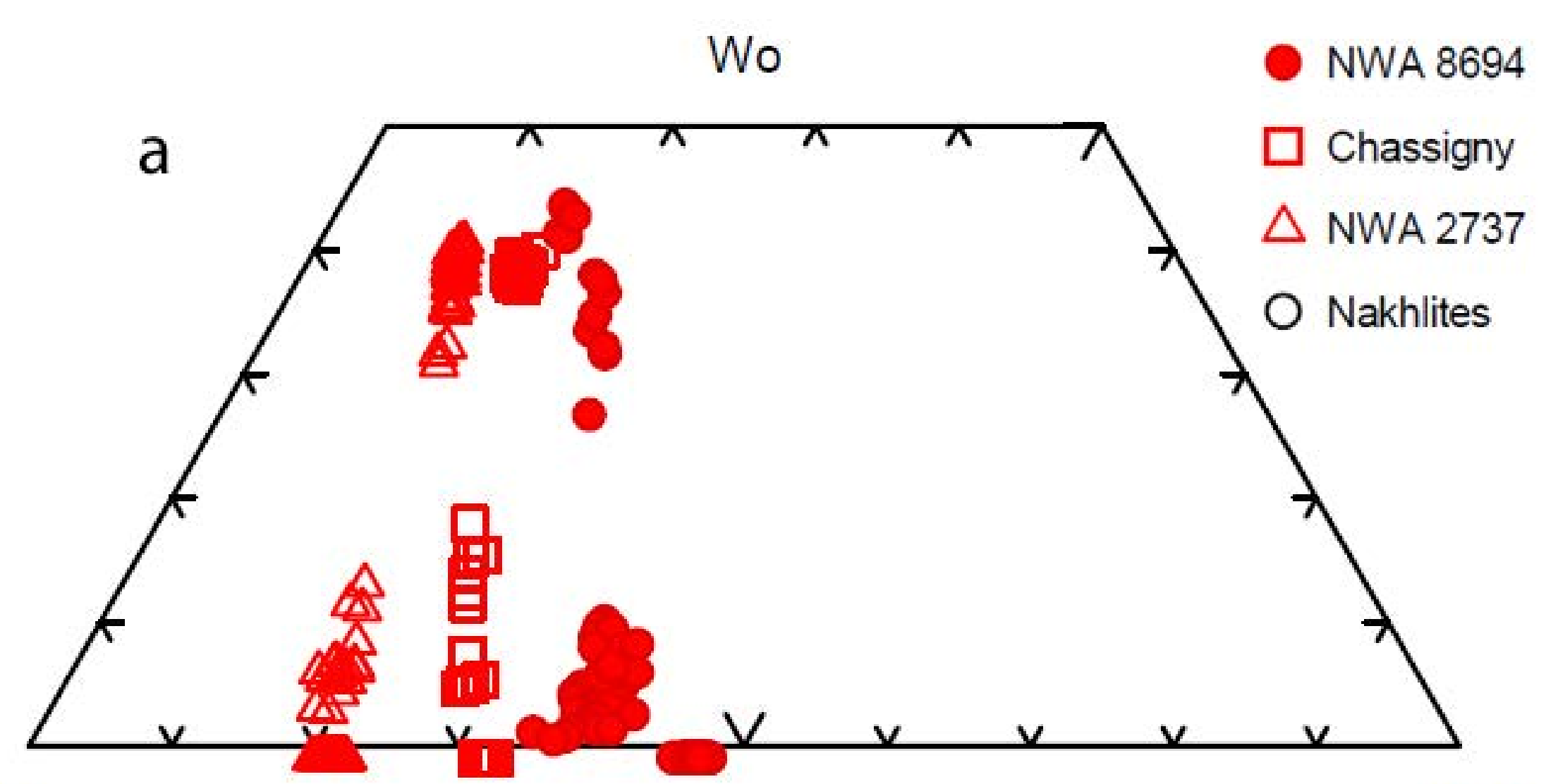

En,Fo

$\mathrm{Fs}, \mathrm{Fa}$

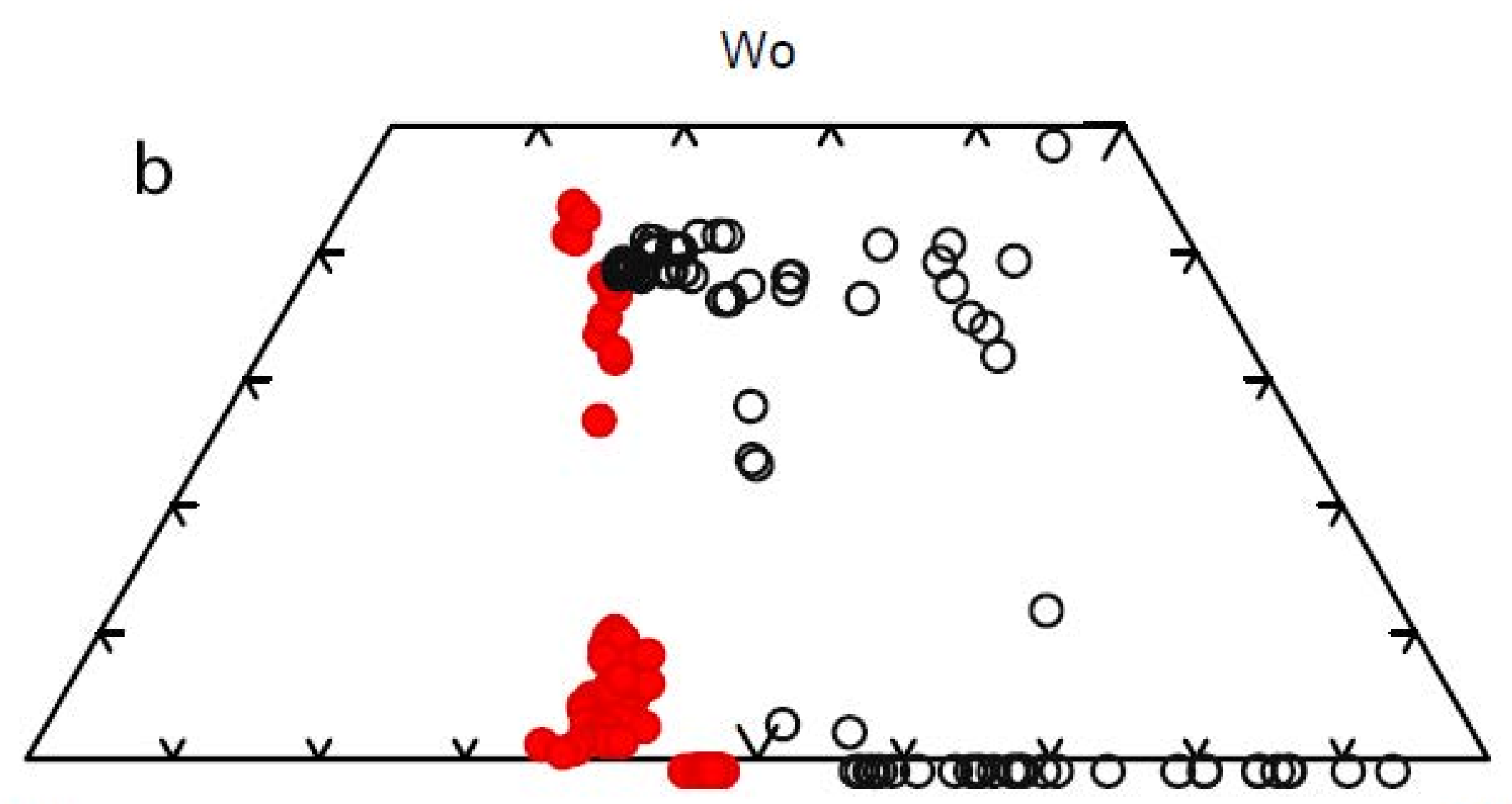

Fo,En

$\mathrm{Fa}, \mathrm{Fs}$ 
Mag50

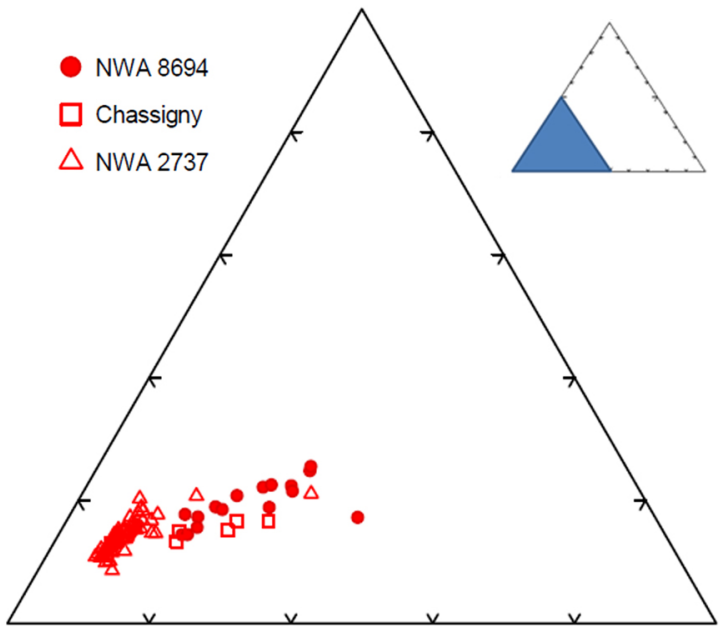

Chr100

Usp50 
Mag50

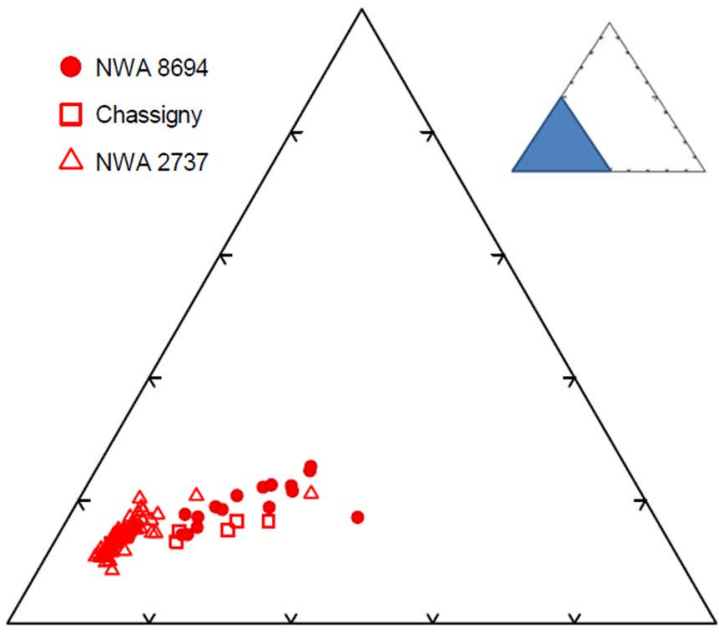

Chr100

Usp50 
Mag50

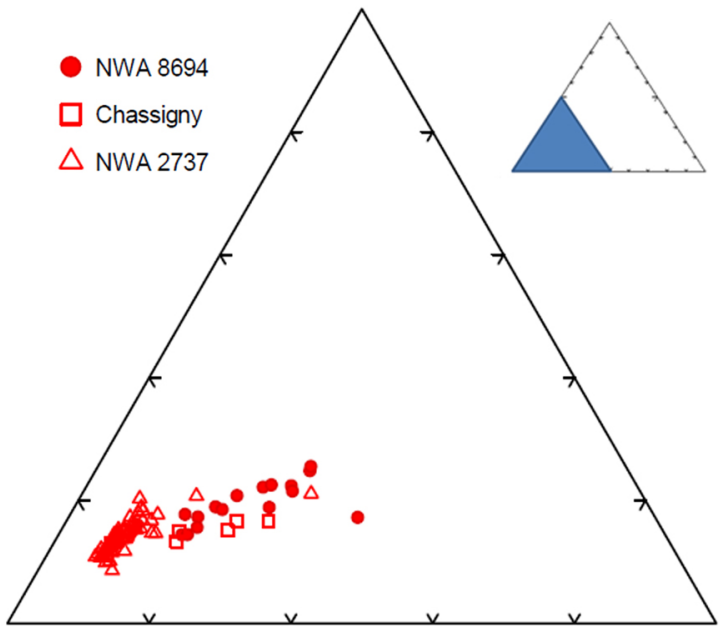

Chr100

Usp50 
An50

- NWA 8694

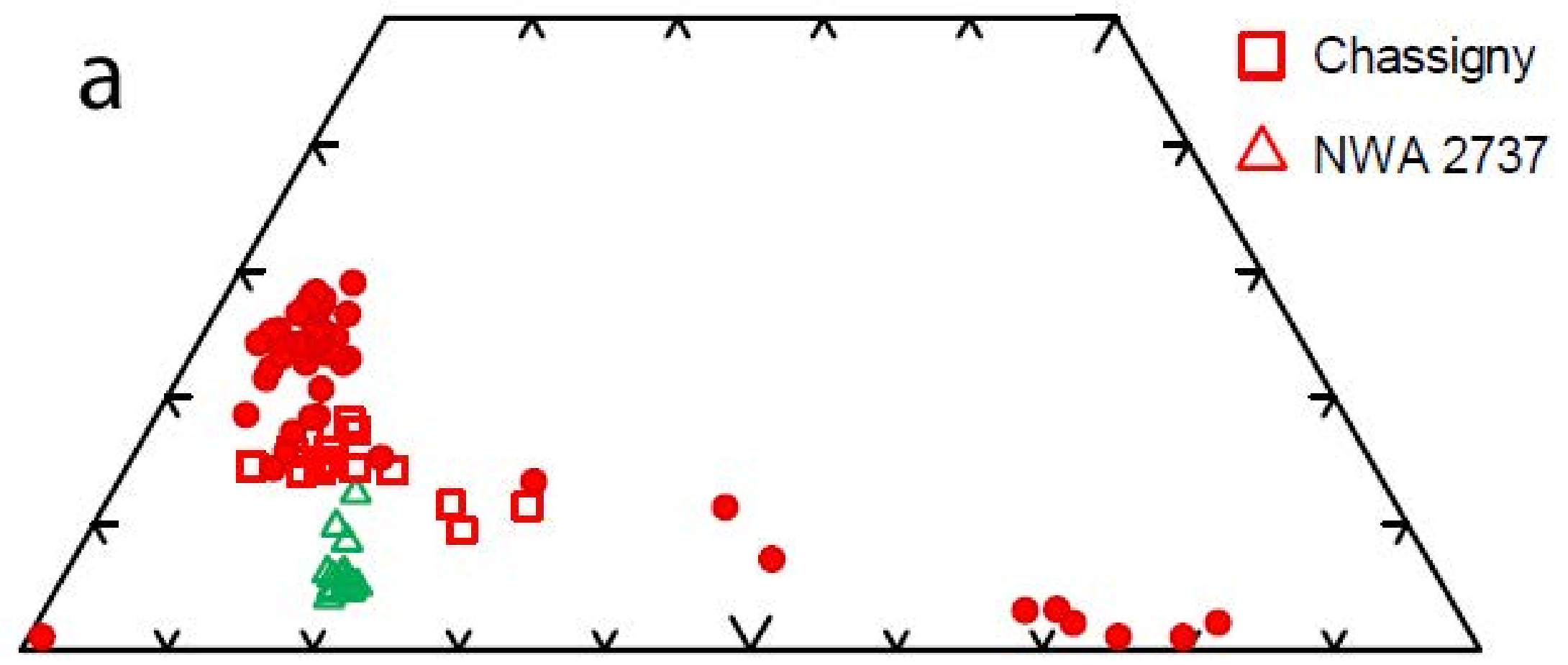

$\mathrm{Ab}$

Or

An50

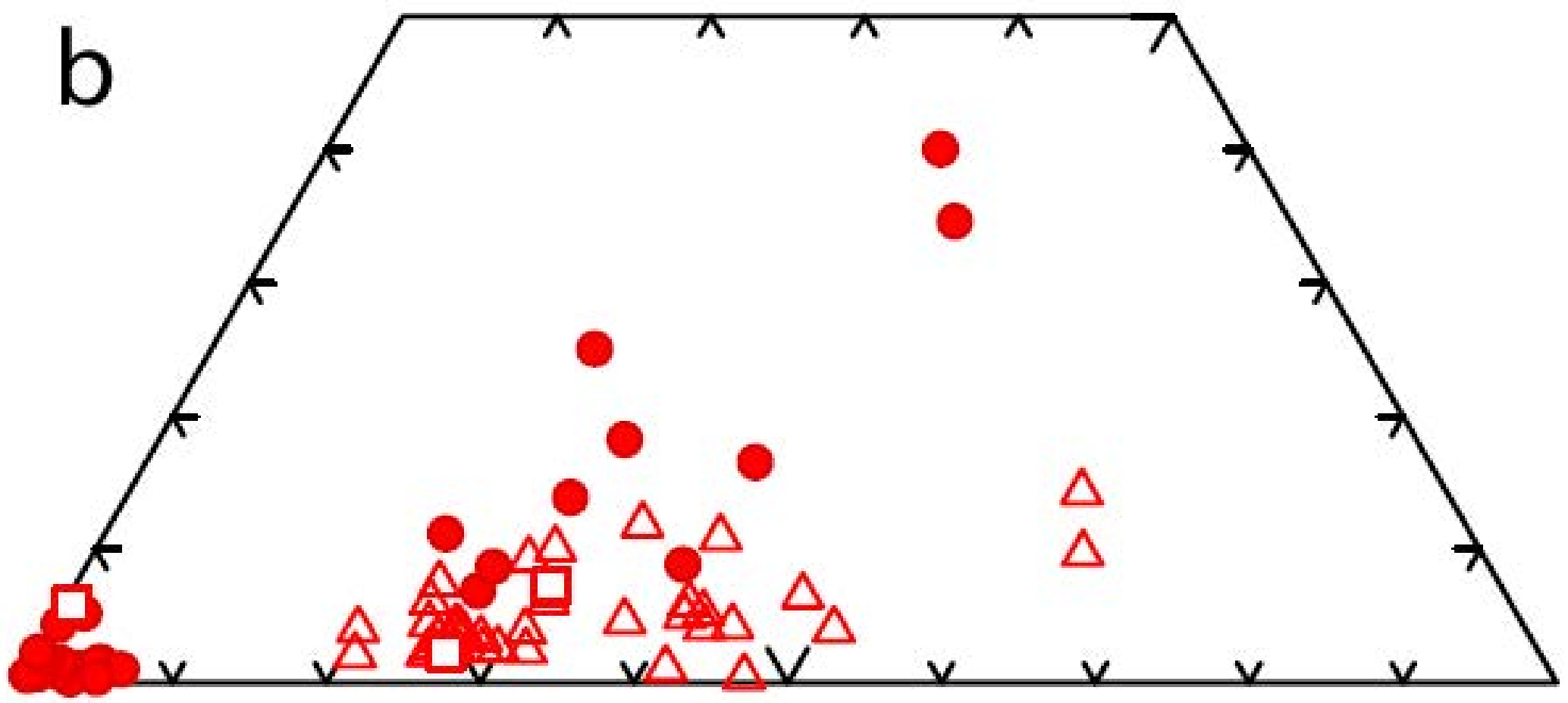

$A b$

Or 
- NWA 2694 Po (inclusions)

= interstitial Po (NWA 8694)

10

= interstitial Po (Chassigny)

= Chassigny Po (inclusions)

8

6

4

0

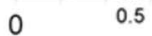

12

2

10

8

6

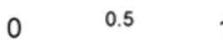

- Py NWA 0694

w Py Chassigny

$\mathrm{Ni}(w \mathrm{t} . \%)$ 


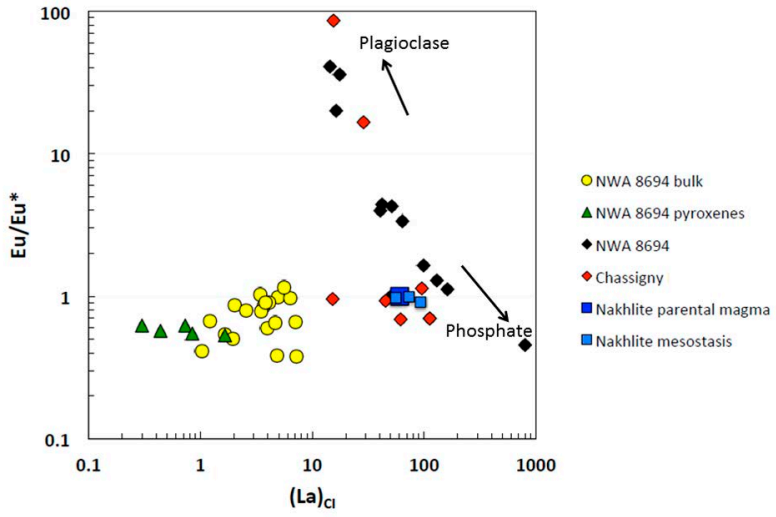




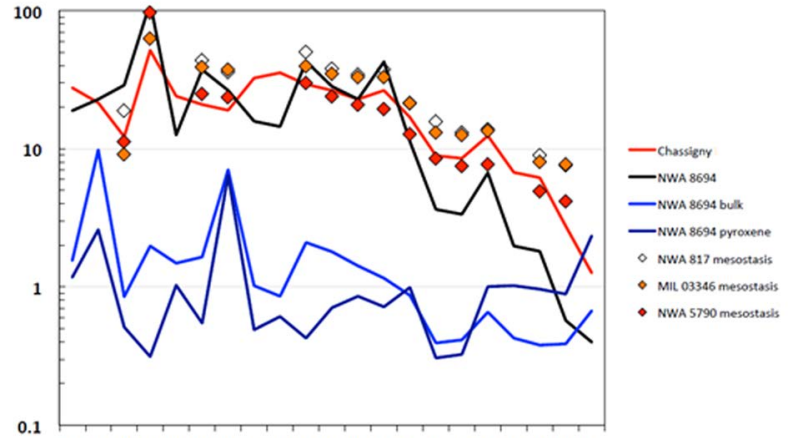

Cs $\mathrm{Tl}$ Rb Ba W Th U Ta Nb La Pr Nd Sr Sm Zr Hf Gd Ho Y Yb Sc 


\section{LeBas et al 1986}

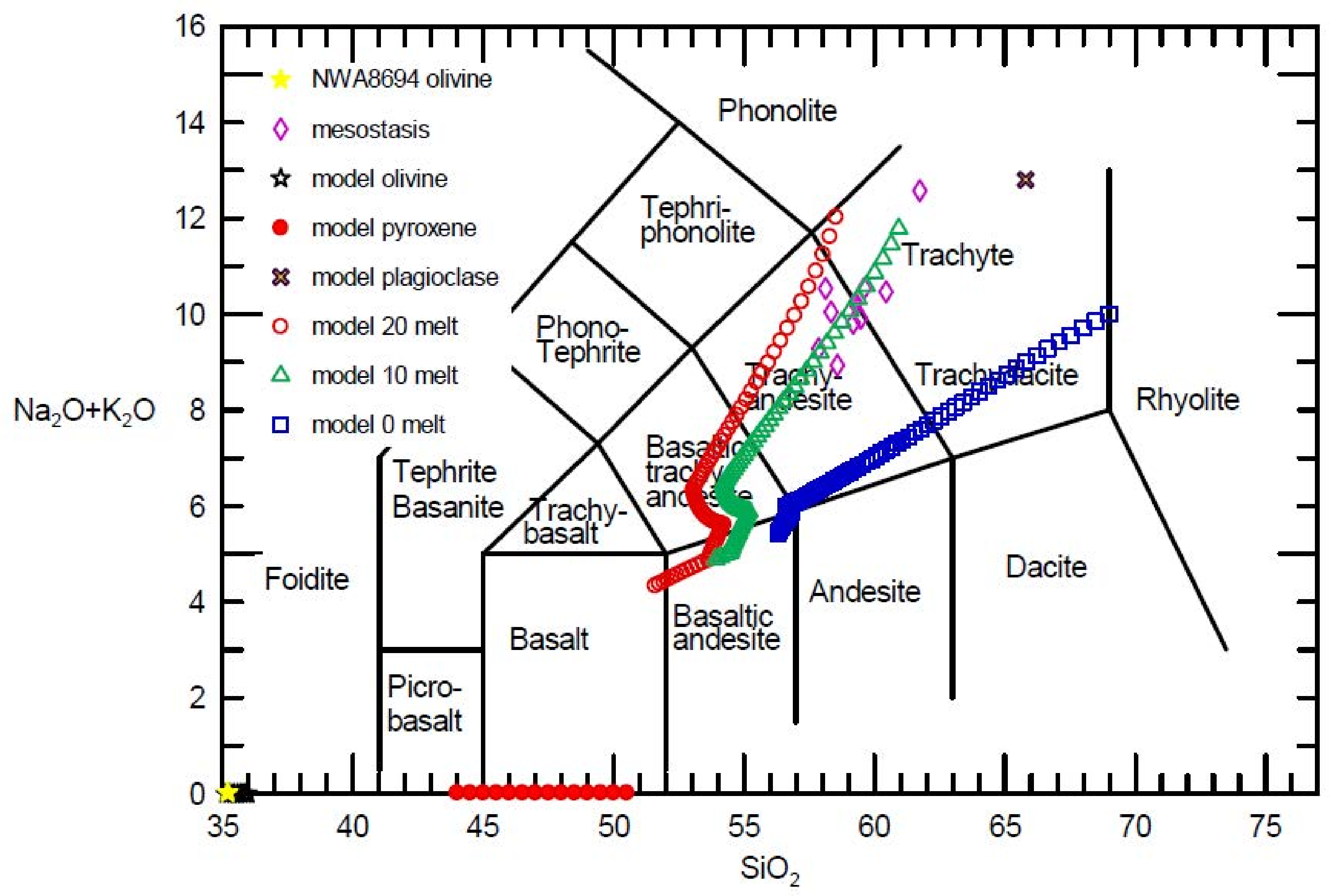


$\mathrm{Fe}_{2} \mathrm{O}_{3}+\mathrm{FeO}$

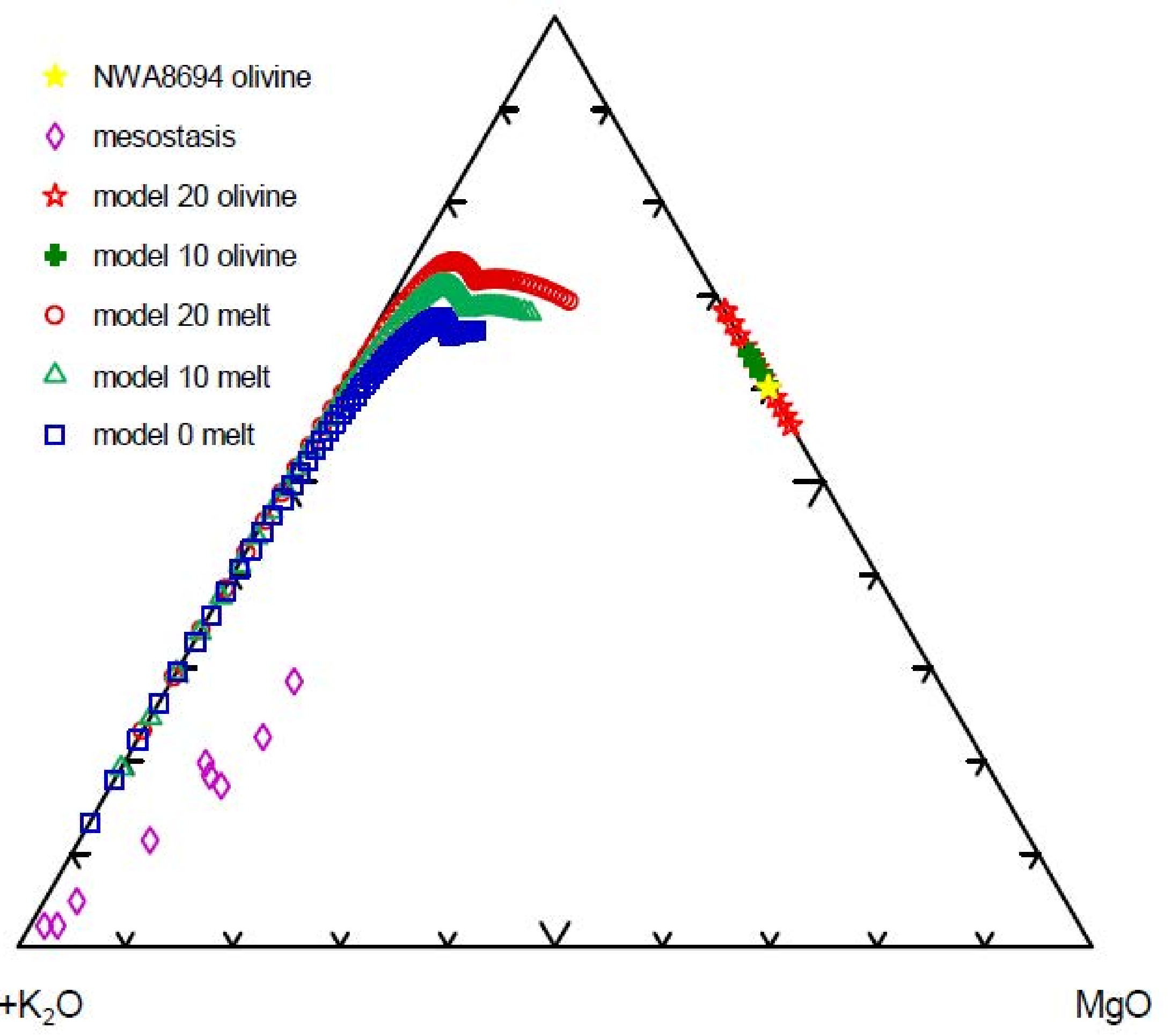


$\mathrm{Fe}_{2} \mathrm{O}_{3}+\mathrm{FeO}$

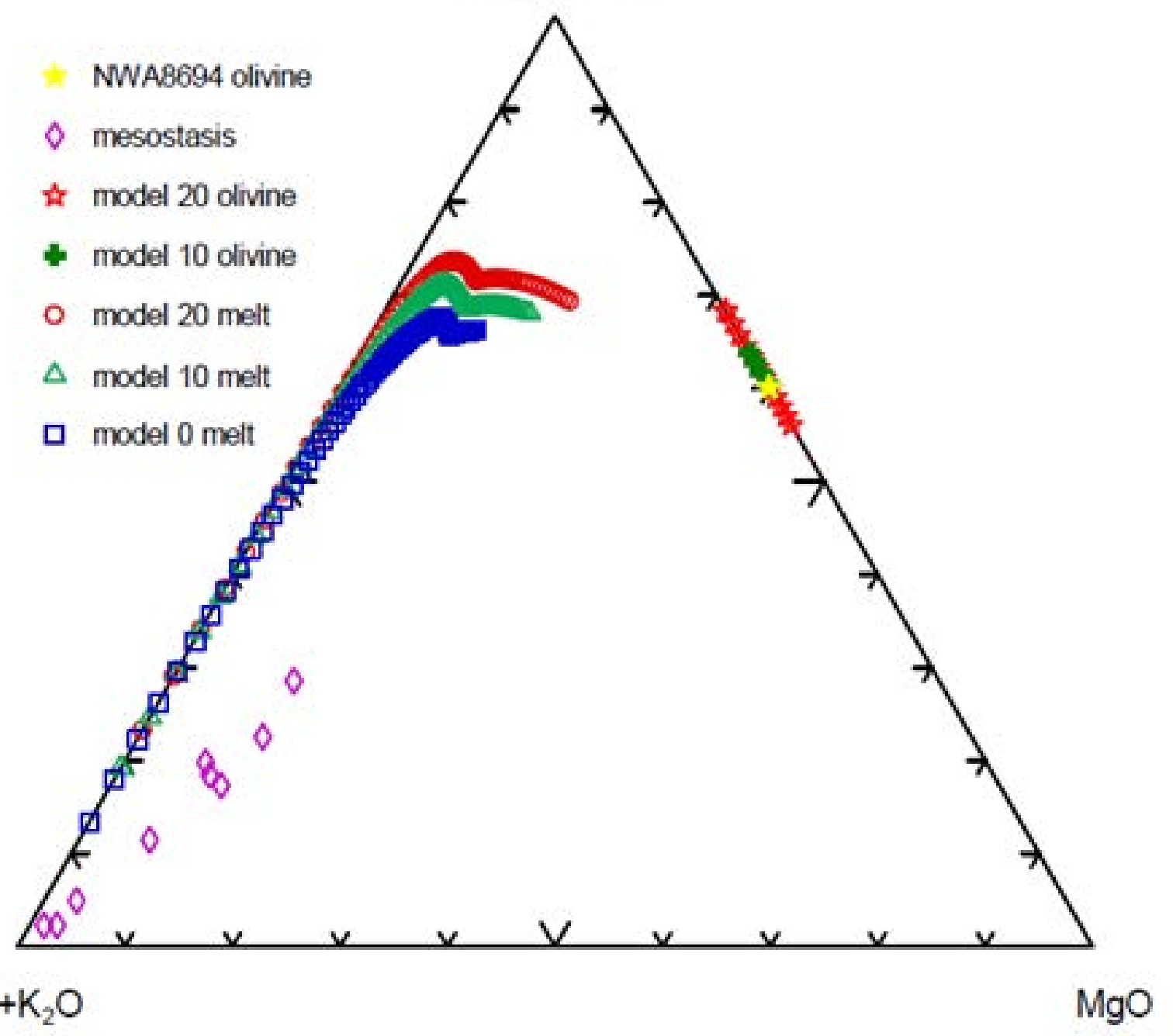




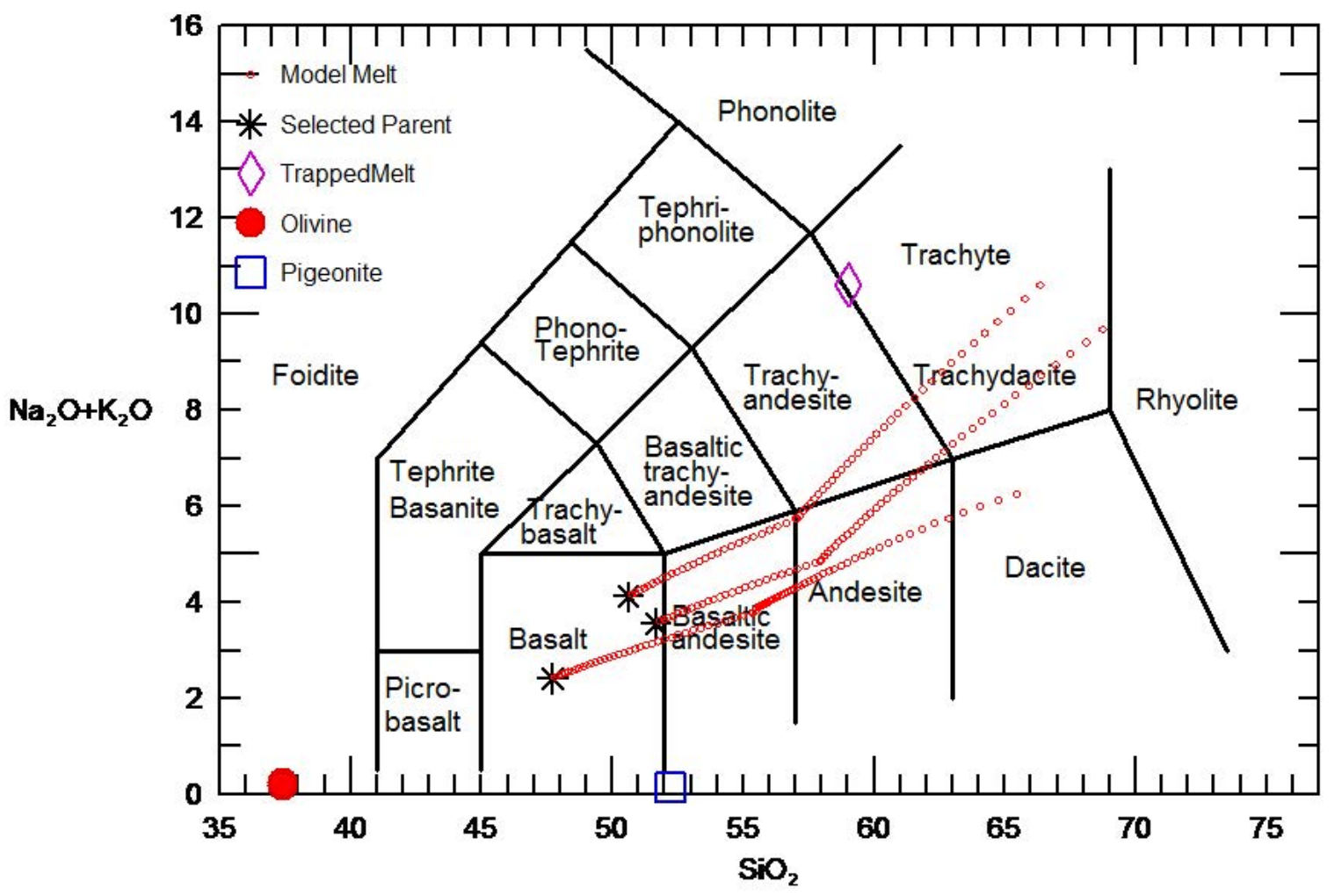


Nakhlite augite mush

Nakhlite Liquid

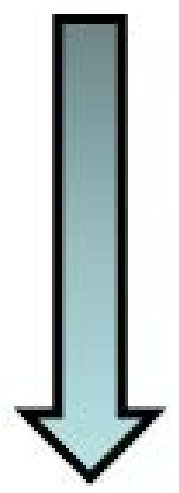

\section{NWA 998}

NWA 8694

$O L+P I G$

Chassignite olivine mush 


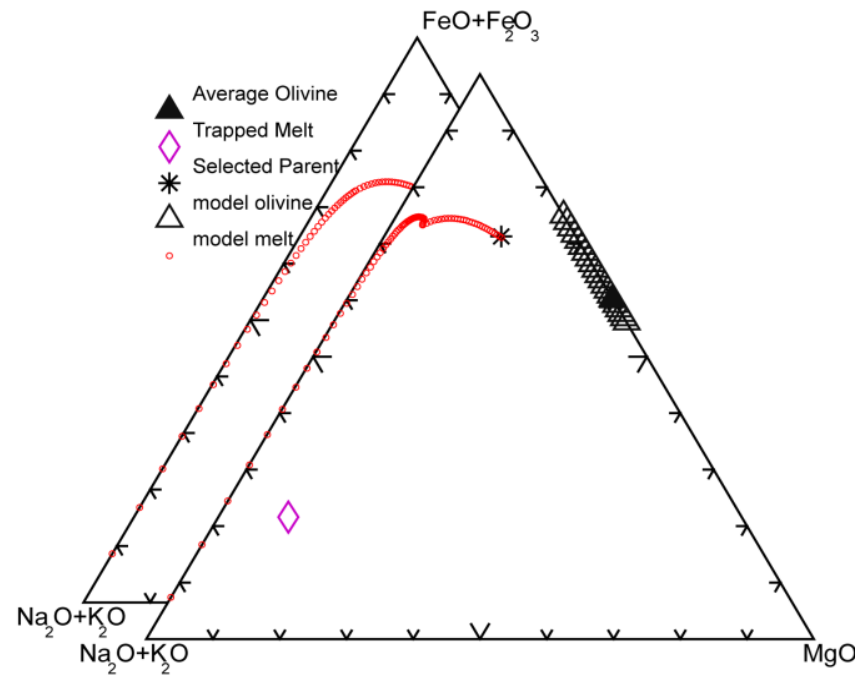




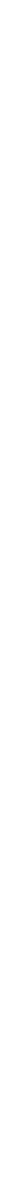




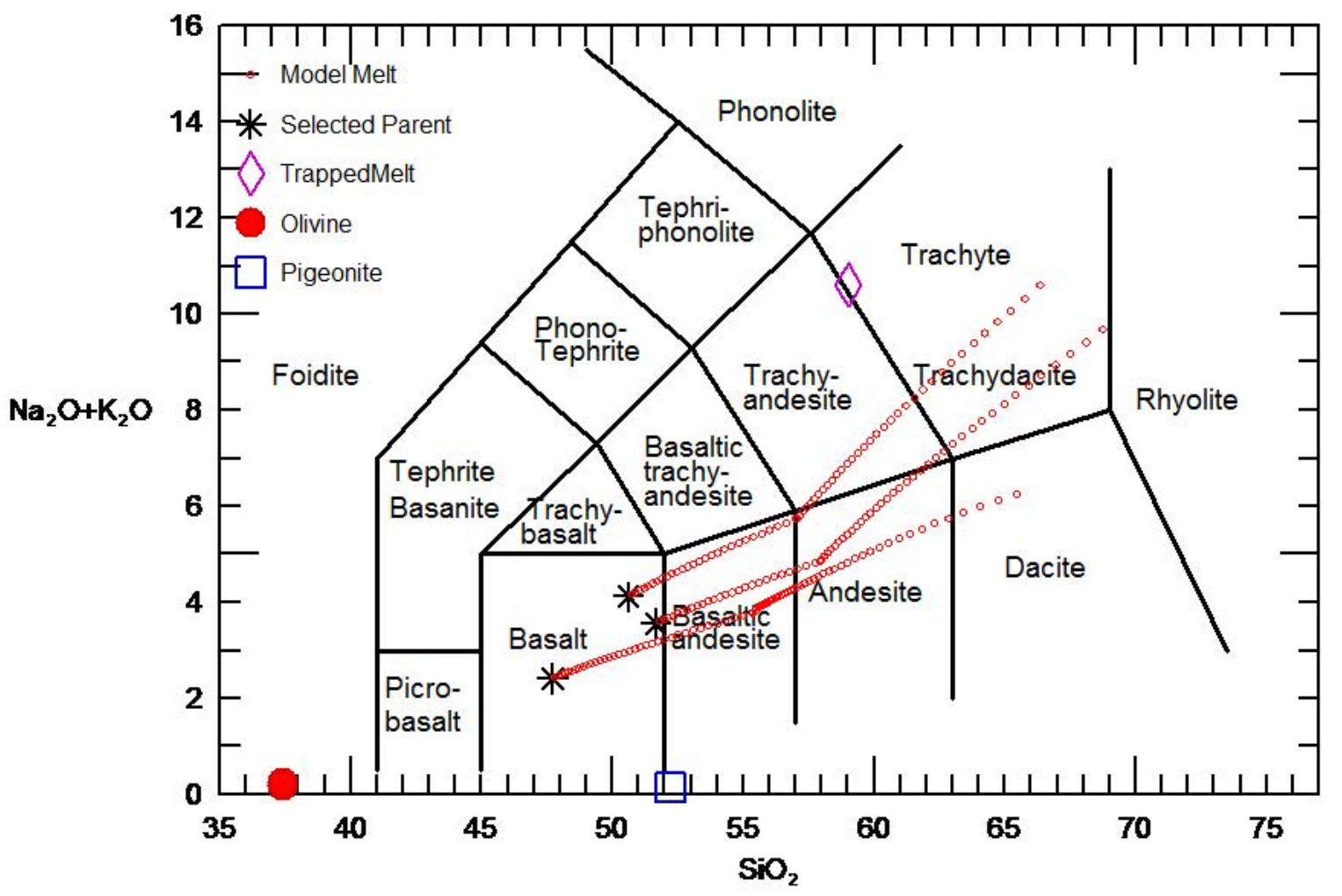

